UNIVERSIDADE DE BRASÍLIA

INSTITUTO DE CIÊNCIAS BIOLÓGICAS

DEPARTAMENTO DE BIOLOGIA CELULAR

PÓS-GRADUAÇÃO EM BIOLOGIA MOLECULAR

\title{
Caracterização de promotores de genes virais durante a infecção de células de inseto com baculovírus recombinantes
}

FABRICIO DA SILVA MORGADO

Orientador: Dr. Bergmann Morais Ribeiro

Tese apresentada ao Programa de Pós-Graduação em Biologia Molecular, do Departamento de Biologia Celular, do Instituto de Ciências Biológicas da Universidade de Brasília como parte dos requisitos para obtenção do título de Doutor em Biologia Molecular.

Brasília, 2017 



\section{RESUMO}

Os baculovírus são vírus que infectam larvas de mariposas e borboletas. São vírus capazes de formar dois fenótipos virais ao longo da infecção celular separados temporalmente. O primeiro fenótipo, os budded vírus, são vírus que brotam da célula e retêm um envelope a partir da membrana celular. Estes servem como agentes da proliferação sistêmica dentro do corpo do hospedeiro. O segundo fenótipo, os occlusion derived virus, são partículas virais envelopadas no núcleo e oclusas dentro da matriz cristalina formada pela proteína poliedrina, abundantemente expressa em momentos muito tardios da infecção. O progresso da infecção e os padrões de expressão gênica são controlados principalmente a nível transcricional, com base na sequência de DNA contida nos promotores dos genes. Para avaliar o programa transcricional e os elementos controladores das infecções baculovirais, desenvolvemos uma nova metodologia de detecção de luminescência em tempo real, derivada da infecção de células de inseto por baculovírus recombinantes contendo promotores de genes expressos em diferentes fases da infecção que controlam a expressão da proteína quimioluminescente Luciferase de vaga-lume. Isto permitiu, de forma inédita, a caracterização detalhada da expressão gênica a partir de promotores dos baculovírus Anticarsia gemmatalis MNPV e Autographa californica MNPV. O que revelou perfis de expressão diferenciais em linhagens permissivas, semipermissivas e não-permissivas à infecção por estes baculovírus. Também foram avaliados promotores do Bracovírus endosimbiótico encontrado em Microplitis demolitor, uma vespa parasita de larvas de Lepidoptera, através da metodologia de medição de luminescência em tempo real. Estes promotores derivados do Bracovírus apresentaram perfis de expressão similares aos de promotores tardios dos baculovírus. A capacidade de transdução e entrega gênica na linhagem celular derivada da vespa $M$. demolitor por baculovírus recombinantes também foi avaliada. 


\begin{abstract}
The baculoviruses are infectious to the larvae of moths and butterflies. These are viruses capable of forming two distinct phenotypes throughout the cellular infection that are temporally separated. The first phenotype, the budded virus, are virions the budded thru the cell membrane, carrying an envelope. These are the agents of the systemic infection within the host's body. The second phenotype, the occlusion derived virus, are enveloped viral particles that are occluded within the crystalline matrix that forms the occlusion bodies, that protect the virus in the environment in the absence of the host. The progress of the cell infection and the patterns of gene expression are controlled at the transcriptional level, mainly based on the DNA sequence of the gene promoters. To evaluate the transcriptional program and the controlling elements of the baculovírus, we developed a new methodology of real time detection of luminescence derived from the infection of insect cells by recombinante baculovírus containing gene promoters of different phases of the infection controlling the chemilluminescent firefly Luciferase protein. This allowed for the detailed characterization of the gene expression from selected Anticarsia gemmatalis and Autographa californica MNPV genes promoters. This revelaed differential patterns of expression in permissive, semipermissive and non-permissive cell lines. We also evaluated gene promoters of the endosymbiont Bracovirus found in Microplitis demolitor, a parasitic wasp of Lepidopteran larvae, using the real-time luminescence detection technique. These promoters revealed patterns similar to late gene promoters from the baculoviruses. The ability of recombinant baculovirus to transduce and deliver genes to a $M$. demolitor wasp derived cell line was also assessed.
\end{abstract}




\section{AGRADECIMENTOS}

Este trabalho só foi possível devido ao apoio integral da minha família: mãe Zilda, pai Durval, irmão Leandro, irmã Juliana e alma gêmea Daniela! Sempre presentes, sempre carinhosos e sempre amados.

Muitos agradecimentos a todas e todos colegas de trabalho do laboratório Baculovírus da UnB. Também não foram esquecidos aqueles que passaram pelo laboratório. É um prazer trabalhar neste laboratório pois o ambiente de trabalho busca fomentar a inquisição científica e criatividade. Isto só foi possível graças aos esforços contínuos do professor Bergmann Morais Ribeiro, um excelente líder e pesquisador inspirador. Muito obrigado prof. Bergmann por compartilhar a sua paciência e sabedoria.

Immense thanks to my colleagues and friends from the Strand Lab at the University of Georgia, USA. It was a powerful and fullfilling experience only possible due to the kindness of dr. Michael R. Strand and his wife Jena Johnson. Thank you for your support and for the excellent learning environment that you provided to me.

A CAPES e CNPq pelo investimento neste trabalho 
Dedicado à minha querida mãe

\author{
Zilda da Silva Morgado
}

Be that as it may, but for that light phantastic of his gnose's glow as it slid lucifericiously within an inch of its page

James Joyce, FW - 182.04 


\section{ÍNDICE}

RESUMO i

ABSTRACT ii

AGRADECIMENTOS iii

ÍNDICE DE FIGURAS, TABELAS E FLUXOGRAMAS ...................................................viii

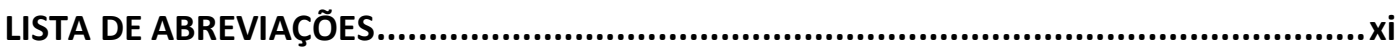

1. INTRODUÇÃO

1.1.Características gerais dos baculovírus............................................................ 1

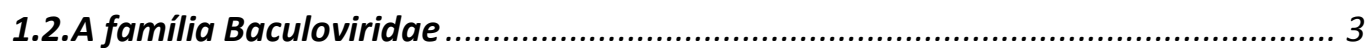

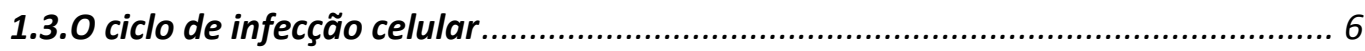

1.4. Baculovírus possuem uma gama restrita de hospedeiros ................................. 13

1.5. Trabalhos anteriores do estudo da atividade de promotores do AgMNPV ......... 19

1.6.A interação simbiótica e biologia do bracovírus Microplitis demolitor BV e seu hospedeiro a vespa Microplitis demolitor ........................................................... 21

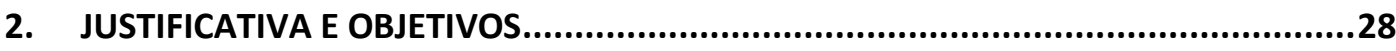

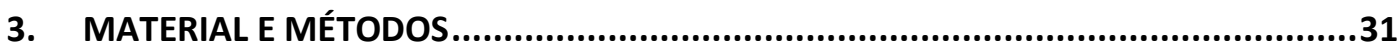

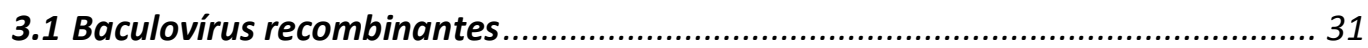

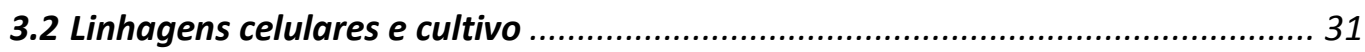

3.3 Isolamento dos promotores virais por PCR e clonagem no vetor de transferência

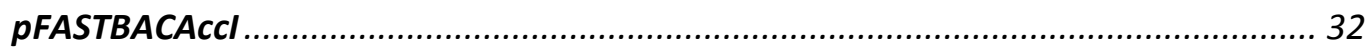

3.4. Construção de baculovírus ACMNPV recombinantes através do método BAC-toBAC.

3.5.Amplificação e titulação dos inóculos virais recombinantes................................ 39

3.6. Ensaios de deteç̧ão da atividade de luciferase em células de inseto................... 40

3.6.1. Ensaios de medição por lise ..................................................................... 41

3.6.2. Ensaios de deteç̧ão da atividade de luciferase em células de inseto (não derivadas de Lepidoptera) transduzidas com baculovírus recombinantes contendo promotores virais

3.6.3. Ensaios de detecção da atividade de luciferase em células de inseto transfectadas com plasmídeos contendo promotores virais ...................................... 44

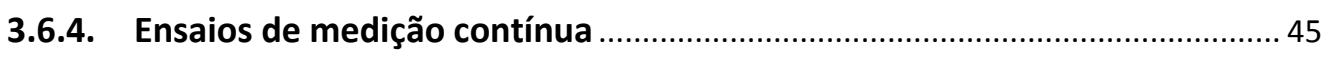

3.6.5. Efeito multiplicidade de infecção (MOI) sobre a expressão dos promotores

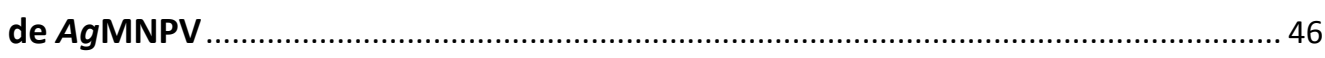

3.6.6. Efeito número de células sobre a expressão dos promotores de AgMNPV47 
3.6.7. Perfil de expressão dos promotores de AgMNPV em células permissivas e não-permissivas.

3.6.8. Perfil de expressão dos promotores de AgMNPV em células de inseto tratadas com o inibidor de replicação Afidicolina

3.6.9. Perfil de expressão dos promotores de AcMNPV, AgMNPV e MdBV durante a infecção de células de inseto com os recombinantes AcMNPV (bacmídeos).

3.7. Quantificação do DNA viral dentro de células de inseto infectadas in vitro utilizando PCR em tempo real

3.8. Quantificação do DNA viral extracelular (BVs) obtido a partir de células de inseto infectadas in vitro através de PCR em tempo real.

3.9. Ensaio de fusão celular mediada pela proteína de envelope GP64 contida nos BVs sobre a linhagem MdE em baixo $\mathrm{pH}$

4. RESULTADOS E DISCUSSÃO .55

4.1. 0 programa de expressão gênica do baculovírus AgMNPV durante a infecção de células de inseto derivadas de Lepidoptera.

4.1.1. A replicação viral e maturação de partículas virais do baculovírus AgMNPV em diferentes linhagens celulares

4.2. O bloqueio da replicação viral e o efeito sobre a atividade dos promotores virais.

4.3. Efeito da multiplicidade de infecção e número de células na expressão dos promotores virais durante a infecção de células de inseto por AgMNPV recombinantes

4.4. 0 programa de expressão gênica do baculovírus AcMNPV durante a infecção de células de inseto derivadas de Lepidoptera e a atividade de promotores heterólogos derivados de AgMNPV..

4.5. Correlação entre atividade dos promotores, motivos dos promotores e função

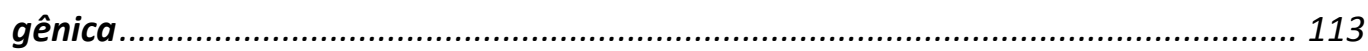

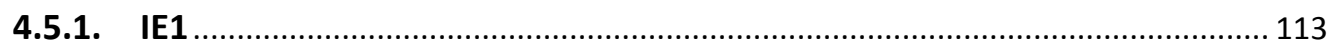

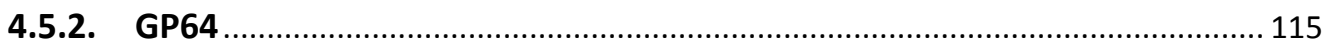

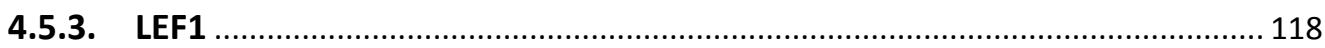

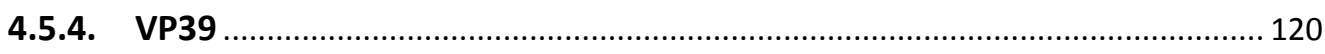

4.5.5. P6.9

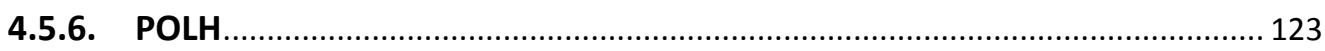

4.6. Os baculovírus AcMNPV e AgMNPV possuem perfis de expressão similares .... 125

4.7.0 perfil de expressão dos promotores de genes não encapsidados de MdBV durante infecções com os AcMNPV recombinantes em linhagens celulares permissivas

4.8.0 perfil dos promotores de genes não encapsidados de MdBV durante transduções de células de inseto não-Lepidoptera 
4.9.0 curioso caso da linhagem celular derivada da vespa Microplitis demolitor ... 143

5. CONCLUSÃO

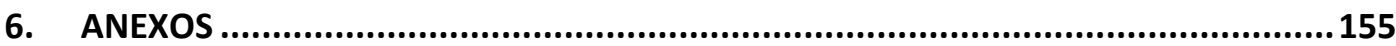

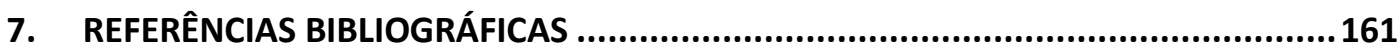




\section{ÍNDICE DE FIGURAS, TABELAS E FLUXOGRAMAS}

Figura 1: Relação filogenética dos quatro gêneros atuais em que se divide a família Baculoviridae. .....6 Figura 2: O progresso da infecção celular com baculovírus em linhagens celulares permissivas e os dois fenótipos gerados a partir da infecção.

Figura 3: Estrutura do núcleo transcricional dos promotores gênicos baculovirais.. ...........................12

Figura 4: Diagrama delineando o procedimento de construção dos baculovírus AgMNPV recombinantes por recombinação homóloga.........................................................................................................20

Figura 5: O ciclo de vida das vespas parasitas Braconidae ou Ichneumoidae e o parasitismo sobre larvas da ordem Lepidoptera. .................................................................................................................26

Figura 6: Diagrama e mapa vetor representando a estratégia de clonagem no plasmídeo de transferência por transposição em E. coli DH10BAC .................................................................37

Figura 7: Curvas de melting de amplificações do gene fluc e a sequência de nucleotídeos dos primers utilizados nas reações de qPCR utilizando materiais de infecções com os baculovírus AgMNPV recombinantes contendo os genes fluc.

Figura 8: Ensaio padrão de medição de quimioluminescência de células infectadas com AgMNPV recombinantes. 60

Figura 9: Ensaios de medição contínua de luminescência nas linhagens UFLAg, Tn5B, Sf9, Ld652Y, Chch e Bm5 durante 4 dias de infecção com os baculovírus AgMNPV recombinantes em MOI 10.......64

Figura 10: Ensaios de medição contínua de luminescência nas linhagens UFLAg, Tn5B, Sf9, Ld652Y, Chch e Bm5 durante 4 dias de infecção com os baculovírus AgMNPV recombinantes em MOI 10.......65

Figura 11: Micrografias das células UFLAg, Tn5B, Sf9, Ld652Y, Bm5 e Chch infectadas com o baculovírus recombinante vAgIE1FLUC às $0 \mathrm{~h}$ p.i. e $96 \mathrm{~h}$ p.i.

Figura 12: Diagrama descrevendo os eventos gerados pela infecção viral e os genes responsáveis ou associados a cada evento

Figura 13: Quantificação do DNA viral intracelular e extracelular por qPCR, durante a infecção de células de inseto pelo baculovírus AgMNPV.

Figura 14: Ensaios de medição contínua de luminescência nas linhagens UFLAg, Tn5B, Sf9 e Ld652Y tratadas com o inibidor de replicação de DNA e infectadas com os baculovírus AgMNPV recombinantes em $\mathrm{MOI} 10$.

Figura 15: Ensaios de medição contínua de luminescência na linhagem UFLAg infectadas com os baculovírus AgMNPV recombinantes vAgGP64FLUC, vAgVP39FLUC, vAgP69FLUC e vAgPOLHFLUC em MOls 100, 50, 10, 5, 1, 0.1, 0.01 e 0.001 .

Figura 16: Ensaios de medição contínua de luminescência na linhagem Tn5B infectadas com os baculovírus AgMNPV recombinantes vAgGP64FLUC, vAgVP39FLUC, vAgP69FLUC e vAgPOLHFLUC em MOls 100, 50, 10, 5, 1, 0.1, 0.01 e 0.001 .

Figura 17: Ensaios de medição contínua de luminescência na linhagem Sf9 infectadas com os baculovírus AgMNPV recombinantes vAgGP64FLUC, vAgVP39FLUC, vAgP69FLUC e vAgPOLHFLUC em MOls $100,50,10,5,1,0.1,0.01$ e 0.001 .

Figura 18: Ensaios de medição contínua de luminescência na linhagem Tn5B infectada com os baculovírus AgMNPV recombinantes vAgIE1FLUC, vAgVP39FLUC, vAgP69FLUC e vAgPOLHFLUC em MOls 10 com concentrações distintas de células semeadas.

Figura 19: Confirmação da clonagem dos diferentes promotores de AgMNPV comandando o gene fluc no plasmídeo pFastBac1 e no bacmídeo de AcMNPV.

Figura 20: Confirmação da clonagem dos diferentes promotores de AcMNPV comandando o gene fluc no plasmídeo pFastBac1 e no bacmídeo de AcMNPV..

Figura 21: Confirmação da clonagem dos diferentes promotores de AgMNPV e AcMNPV comandando o gene fluc no bacmídeo de AcMNPV. 
Figura 22: Confirmação da construção dos bacmídeos AcMNPV contendo os promotores AgPOLH de AgMNPV e AcPOLH de AcMNPV comandando o gene fluc nos recombinantes AcMNPV............98

Figura 23: Ensaios de medição contínua de luminescência das infecções com os baculovírus AcMNPV recombinantes contendo promotores de AcMNPV (coluna esquerda) e AgMNPV (coluna direita) nas linhagens UFLAg, Tn5B e Sf9 ao longo de 3 dias de infecção em MOI 10.

Figura 24: Ensaios de medição contínua de luminescência das infecções com os baculovírus AcMNPV recombinantes contendo promotores de AcMNPV (coluna esquerda) e AgMNPV (coluna direita) nas linhagens Ld652Y, Bm5 e Chch ao longo de 3 dias de infecção em MOI 10. 106

Figura 25: Alinhamento dos promotores IE1 de AcMNPV e AgMNPV.........................................113

Figura 26: Alinhamento dos promotores GP64 de AcMNPV e AgMNPV. ......................................115

Figura 27: Alinhamento dos promotores LEF1 de AcMNPV e AgMNPV. .......................................118

Figura 28: Alinhamento dos promotores VP39 de AcMNPV e AgMNPV.. .......................................120

Figura 29: Alinhamento dos promotores P6.9 de AcMNPV e AgMNPV.. ......................................121

Figura 30: Alinhamento dos promotores POLH de AcMNPV e AgMNPV.........................................123

Figura 31: Confirmação da clonagem dos diferentes promotores de $M d B V$ comandando o gene fluc no bacmídeo de AcMNPV

Figura 32: Ensaio de medição contínua de luminescência da infecção das linhagens de Lepidoptera Tn5B e Sf9 com os baculovírus recombinantes AcMNPV contendo os promotores derivados de $M d B V$ ao longo de 3 dias de infecção..

Figura 33: Medição de luminescência a partir da transfecção dos plasmídeos contendo os promotores isolados regulando a luciferase de vaga-lume na linhagem Tn5B..

Figura 34: Medição de luminescência de células transduzidas (S2, MdE e Aaeg) e infectadas (Tn5B) com os baculovírus recombinantes contendo promotores virais regulando o gene fluc.

Figura 35: Ensaios de fusão celular da linhagem MdE mediada pela proteína de envelope viral GP64. 146

Figura 36: Análise da concentração de DNA do vírus AcMNPV ao longo de $72 \mathrm{~h}$ de infecção da linhagem Tn5B (Hi5) e transdução das linhagens S2 e MdE. 148

Figura 37: Curvas de expressão do gene repórter fluc durante as infecções da linhagem UFLAg pelos baculovírus AgMNPV recombinantes contendo promotores dos genes gp64, vp39, p6.9 e polh.

Figura 38: Curvas de expressão do gene repórter fluc durante as infecções da linhagem Tn5B pelos baculovírus AgMNPV recombinantes contendo promotores dos genes gp64, vp39, p6.9 e polh.

156

Figura 39: Curvas de expressão do gene repórter fluc durante as infecções da linhagem Sf9 pelos baculovírus AgMNPV recombinantes contendo promotores dos genes gp64, vp39, p6.9 e polh.

Figura 40: Exemplo de mapa vetor do plasmídeo de transferência por transposição pFASTBAC modificado. 158

Figura 41: Mapas vetores linearizados dos plasmídeos pFASTBAC modificados contendo os promotores de AcMNPV e AgMNPV isolados e clonados a montante do gene FLUC. 159

Figura 42: Mapas vetores linearizados dos plasmídeos pFASTBAC modificados contendo os promotores de MdBV isolados e clonados a montante do gene FLUC. 160 
Fluxograma 1: Descrição geral dos procedimentos e materiais utilizados para estudar as infecções dos baculovírus recombinantes AgMNPV e AcMNPV contendo promotores virais derivados de AgMNPV ou AcMNPV regulando o gene repórter quimioluminescente fluc.

Fluxograma 2: Descrição geral dos procedimentos e materiais utilizados para estudar as infecções dos baculovírus recombinantes AcMNPV contendo promotores do vírus Microplitis demolitor Bracovírus regulando o gene repórter quimioluminescente fluc.

Tabela 1: Lista dos primers utilizados no isolamento dos promotores virais.

Tabela 2: Tempo de primeira detecção $\left(T_{\text {in }}\right)$ do sinal de luminescência (hh:mm) ..............................66

Tabela 3: Tempo até atingir pico $\left(T_{\mathrm{pi}}\right)$ de expressão do sinal de luminescência $(\mathrm{hh}: \mathrm{mm})$.....................66

Tabela 4: Tempo de primeira detecção $\left(T_{\text {in }}\right)$ do sinal de luminescência ( $\left.h \mathrm{~h}: \mathrm{mm}\right)$, ensaio com células tratadas com Afidicolina.

Tabela 5: Tempo de primeira detecção $\left(T_{\text {in }}\right)$ do sinal de luminescência (hh:mm), ensaio com os baculovírus AcMNPV recombinantes contendo os promotores de AcMNPV e AgMNPV em diferentes linhagens derivadas de Lepidoptera.

Tabela 6: Tempo de primeira detecção ( $T_{\text {in }}$ ) do sinal de luminescência ( $h \mathrm{~h}: \mathrm{mm}$ ), ensaio com células infectadas com os baculovírus AcMNPV recombinantes contendo os promotores derivados de MdBV.

Tabela 7: Descrição dos elementos transcricionais presentes nos promotores derivados de MdBV. .137 


\section{LISTA DE ABREVIAÇÕES}

Aaeg2: $\quad$ linhagem celular Aaeg2

AgMNPV: $\quad$ Anticarsia gemmatalis multiple nucleopolyhedrovirus

AcMNPV: $\quad$ Autographa californica multiple nucleopolyhedrovirus

BV: $\quad$ budded virus, virus extracelular baculoviral

Bm5: $\quad$ linhagem celular $\mathrm{Bm} 5$

BmNPV: $\quad$ Bombyx mori nucleopolyhedrovirus

CfMNPV: $\quad$ Choristoneura fumiferana multiple nucleopolyhedrovirus

Chch: $\quad$ Linhagem celular Wu-Cce-1

ChchSNPV: $\quad$ Chrysodeixes chalcites single nucleopolyhedrovirus

CpGV: $\quad$ Cydia polmonella granulovirus

dpi: $\quad$ dias após a infecção

FBS: $\quad$ fetal bovine serum, soro fetal bovino

FLUC: $\quad$ firefly luciferase, Luciferase do vaga-lume Photinus pyralis

GP64: $\quad$ glicoproteína do envelope de BV

hpi: $\quad$ horas após a infecção

IE1: $\quad$ proteína transativadora de transcrição immediate early 1

kpb: $\quad$ kilo pares de bases

LEF1: $\quad$ primase associada a DNA polimerase baculoviral

Ld652Y: $\quad$ linhagem celular IPLB-Ld652Y

LdMNPV: $\quad$ Lymantria dispar multiple nucleopolyhedrovirus

MdBV: $\quad$ Microplitis demolitor Bracovirus

MdE: $\quad$ linhagem celular UGA-MdE1

MOI: $\quad$ multiplicity of infection, multiplicidade de infecção 
OB:

ODV:

OpMNPV:

P6.9:

pb:

PCR:

PFU:

POLH:

qPCR:

RLU:

RNA pol:

S2:

Sf9:

$\mathrm{TCID}_{50}$ :

$T_{\text {in: }}$

$\mathrm{T}_{\mathrm{pi}}$ :

Tn5B:

UFLAG:

$\mathrm{V}_{\text {max }}$ :

VP39: occlusion bodies, corpos de oclusão ou poliedros

occlusion derived virus, virus derivado de oclusão

Orgyia pseudotsugata multiple nucleopolyhedrovirus

proteína estrutural associada ao DNA viral dos baculovírus

pares de bases

polymerase chain reaction, reação de polimerização de DNA em cadeia

poly DNA virus

plaque forming units, unidades formadoras de placa

poliedrina, proteína estrutural formadora da matriz cristalina do $\mathrm{OB}$

PCR quantitativa

relative light units, unidades relativas de luz

RNA polimerase

linhagem celular Schneider 2

linhagem celular Sf9, derivada de IPLB-Sf21-AE

tissue culture infectious dose $50 \%$, dose infectiva a 50\% da cultura

tempo de primeira detecção do sinal de luminescência

tempo até atingir o pico de luminescência

linhagem celular BTI-Tn5B1-4

linhagem celular UFL-Ag-286

valor de luminescência no pico de expressão em RLU

proteína estrutural do capsídeo baculoviral 


\section{INTRODUÇÃO}

\subsection{Características gerais dos baculovírus}

Os baculovírus são vírus com partícula viral no formato de bastão, envelopados, com DNA dupla fita, circular e de tamanho em média de $130 \mathrm{kpb}$ (kilo pares de bases) (Rohrmann, 2013). São um grupo de vírus de artrópodes, principalmente das ordens Lepidoptera, Himenoptera e Diptera (Jehle et al., 2006). Uma das características principais dos baculovírus é a capacidade de produzir dois fenótipos virais, morfológica e temporalmente distintos: o primeiro fenótipo observado durante a infecção é denomindado de budded virus (BV), produzido em uma fase inicial da infecção celular e é composto por um virion que atravessa a membrana plasmática carregando parte dela. $\mathrm{O}$ segundo fenótipo chama-se occlusion derived virus (ODV) formados em momentos mais tardios da infecção e compostos por virions envelopados no núcleo da célula, que são envoltos por uma oclusão cristalina de origem protéica, denominada de corpo de oclusão ou occlusion body (OB), formado pela proteína poliedrina (POLH). Os OBs são os agentes infectivos primários que garantem a viabilidade das partículas virais em seu interior contra os rigores do meio ambiente, como luz UV e umidade, até serem ingeridos por um novo hospedeiro suceptível, iniciando uma nova infecção. Desta forma, a infecção primária ocorre pela ingestão de OBs por via oral, enquanto os BVs são os agentes de infecção secundária, permitindo a proliferação da infecção viral dentro do hospedeiro (Slack \& Arif, 2007).

O Anticarsia gemmatalis multiple nucleopolyhedrovirus (AgMNPV) isolado 2D (Johnson \& Maruniak, 1989) pertence ao Grupo I dos Alphabaculovirus com genoma composto por 132,239 pb (pares de bases) de DNA dupla fita, patogênico à lagarta de Anticarsia gemmatalis (Hubner), uma praga da soja (Glycine max) (Moscardi et al., 1999; Oliveira et al., 2006). Os OBs do baculovírus $A g \mathrm{MNPV}$ vêm sendo utilizados por mais 
de 30 anos no Brasil como bioinseticida para controlar a população da lagarta Anticarsia gemmatalis, produzido artesanalmente ou por formulações comerciais, formando uma importante alternativa ao uso de inseticidas químicos, diminuindo assim os danos ambientais e sociais, além de reduzir custos de produção (Moscardi et al., 1999; Rodas et al., 2005; Haase et al, 2015).

Um marco importante na história do conhecimento deste vírus foi $o$ sequenciamento completo do genoma $A g M N P V-2 D$ (Oliveira et al., 2006), isto permitiu integrar diversos estudos moleculares independentes sobre genes e fragmentos do genoma até então sequenciados, elucidar eventos evolutivos como transversões, variações na sequência genômica em relação aos demais baculovírus, proteínas únicas ao $A g M N P V$ e construir uma filogenia mais acurada. $\mathrm{O}$ sequenciamento também confirmou que o baculovírus $A g \mathrm{MNPV}$ não possui dois genes, cathepsin e chitinase, presentes no genoma de quase todos Alphabaculovirus (Slack et al, 2004). Estas duas proteínas estão relacionadas com a liquefação do corpo das larvas infectadas pelos demais baculovírus que auxiliam na dispersão dos OBs no campo (Rohrmann, 2013; Lima et al, 2013). A ausência destas proteínas durante a infecção das larvas Anticarsia gemmatalis, impede o rompimento da cutícula exterior composta de quitina, após a morte da larva. Esta característica única do $A g \mathrm{MNPV}$ é muito desejada em seu uso no laboratório como vetor de expressão de proteínas de interesse, se considerarmos que a protease v-CATHEPSIN $(v$-cath) pode degradar a proteína recombinante e reduzir a produtividade da expressão (Jarvis et al, 1996).

O baculovírus AcMNPV é um Alphabaculovirus Grupo I com tamanho de 132 kpb com maior número de estudos dedicados à sua biologia e aplicações biotecnológicas. Uma boa parte das noções fundamentais da biologia dos baculovírus apresentada nesta introdução tem como base os estudos realizados neste baculovírus “protótipo”. Após seu 
isolamento em 1971 (Vail et al, 1971) teve as metodologias básicas de manipulação in vitro estabelecidas ainda no início dos anos 80 , graças à ampla variedade de células hospedeiras então disponíveis, o que consequentemente permitiu que sua genética fosse gradualmente elucidada. Foi o primeiro baculovírus com o DNA completamente sequenciado (Ayres et al, 1994), serviu como base para a elucidação dos mecanismos transcricionais desta família de vírus (Beniya et al, 1996) e a descoberta dos elementos de replicação do DNA viral (Kool et al, 1994). Também foi o primeiro baculovírus estabelecido como a metodologia BAC-to-BAC de manutenção do DNA viral na forma de um replicon em bactérias Escherichia coli, o que facilitou a engenharia genética do vírus e permitiu a formação de um sistema comercial de expressão de proteínas em células de inseto, bem estabelecido, com aplicações diversas em biologia molecular (Luckow et al, 1993). Atualmente, o conhecimento acumulado sobre o $A c \mathrm{MNPV}$ já avançou ao ponto de existirem estudos de deleção de praticamente todos os genes virais individualmente (revisado em Rohrmann, 2013) e um transcriptoma derivado da infecção de células de Trichoplusia ni, Tn5B (Chen et al, 2013).

Em comparação ao $A c \mathrm{MNPV}$, a biologia molecular do baculovírus $A g \mathrm{MNPV}$ não foi aprofundada e seu foco principal tem sido o uso como bioinseticida no controle da lagarta da soja. As diferenças genéticas relatadas acima entre os dois vírus e as distinções em termos de espectro de hospedeiros torna a comparação direta entre estes dois Alphabaculovirus um estudo muito interessante.

\subsection{A família Baculoviridae}

Esta família de vírus de inseto tem como características principais um material genético composto por DNA dupla fita circular de tamanho variável, entre 80 e $160 \mathrm{kpb}$ (kbp, Rohrmann, 2013). É composta por 4 gêneros: Alphabaculovirus, Betabaculovirus, 
Gammabaculovirus e Deltabaculovirus. Destes os gêneros mais estudados são os Alphabaculovirus composto pelos Nucleopoliedrovirus (NPVs) sendo a espécie tipo o AcMNPV. O gênero Betabaculovirus é composto pelos granulovírus (GVs) que também são capazes de formar dois fenótipos infectivos mas os corpos de oclusão (grânulos) possuem tamanho menor que os OBs e possuem como composição principal a proteína granulina.

O baculovírus filogeneticamente mais próximo ao $A g \mathrm{MNPV}$ é o Choristoneura fumiferana defective nucleopolyhedrovirus (CfDEFNPV), que ocorre em conjunto a outro baculovírus chamado de Choristoneura fumiferana multiple nucleopolyhedrovirus (CfMNPV), dentro da larva hospedeira Choristoneura fumiferana, uma praga de florestas de clima temperado no Canadá (Lauzon et al., 2005). A similaridade na identidade dos aminoácidos das proteínas codificadas por ambos vírus é muito alta, acima de $92 \%$, se considerarmos as proteínas estruturais do BV e dos corpos de oclusão. Mesmo existindo alta homologia entre os dois genomas, eles são distintos, pois existem inversões na sequência de DNA genômico e topologia dos genes virais (Oliveira et al., 2006).

Considerando o alinhamento de 29 genes comuns entre os baculovírus sequenciados, proposto por Jehle et al. (2006), a filogenia dos baculovírus está organizada em 4 grupos, apresentada na Figura 1, que constituíram os atuais gêneros da família Baculoviridae:

- Alphabaculovirus: inclui os baculovírus específicos a hospedeiros da ordem Lepidoptera. Este gênero se subdivide em dois tipos, os Alphabaculovirus do Grupo I, que inclui a espécie tipo $A c \mathrm{MNPV}$ e o baculovírus $A g \mathrm{MNP}$. Estes utilizam a proteína GP64 como principal glicoproteína de envelope do BV; os Alphabaculovirus do Grupo II, que inclui o baculovírus Lymantria dispar MNPV, utilizam a proteína F como principal glicoproteína do envelope do BV. Produzem BV e ODV como 
fenótipos infectivos, sendo que os ODVs podem ser encontrados formando múltiplos vírus por envelope (nos vírus denominados de MNPVs) ou vírus únicos por envelope (nos denominados de SNPVs). A proteína formadora do corpo de oclusão (denominado de poliedro nesse grupo de vírus) é a poliedrina (POLH).

- Betabaculovirus: incluem os granulovírus específicos a hospedeiros da ordem Lepidoptera, produzem BV e ODV, sendo que a proteína que forma o corpo de oclusão (denominado de grânulo nesse grupo de vírus) chama-se granulina. A espécie tipo deste gênero é o Cydia polmonella GV (CpGV).

- Gammabaculovirus: incluem os NPVs encontrados em hospedeiros da ordem Hymenoptera (vespas). Produzem OBs com apenas uma partícula viral ODV. A espécie tipo é o Neodiprion lecontei NPV (NeleNPV).

- Deltabaculovirus: incluem os baculovírus específicos à ordem Diptera (mosquitos), a espécie tipo é Culex nigripalpus NPV (CuniNPV). Produz OBs cuja proteína principal não é homóloga a granulina ou poliedrina dos demais gêneros. 


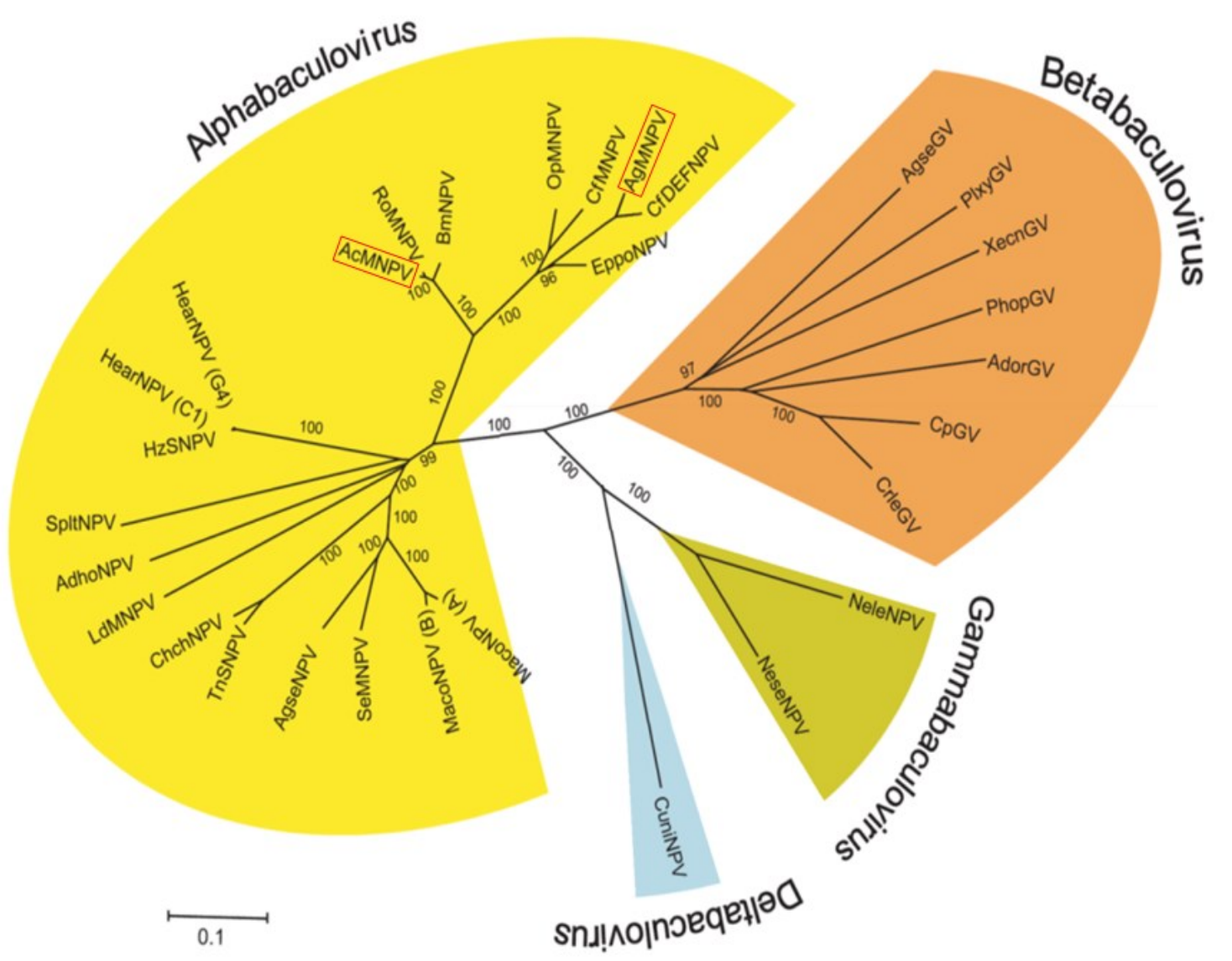

Figura 1: Relação filogenética dos quatro gêneros atuais em que se divide a família Baculoviridae. Árvore mostrando a relação de proximidade filogenética com base em sequências gênicas ou aminoacídicas e conseqüente agrupamento nos quatro gêneros atualmente aceitos. Estão sendo destacados em caixa vermelha os Alphabaculovirus AcMNPV e AgMNPV, que ocupam os dois clados distintos dentro do grupo Alphabaculovirus Grupo I. A árvore foi modificada de Jehle et al. (2006); na figura original não existe o vírus AgMNPV. Esta modificação foi feita com base em Oliveira et al. (2006)

\subsection{O ciclo de infecção celular}

A infecção de células de inseto por baculovírus (figura 2) se inicia com a adsorção de partículas infectivas (BV ou ODV) na superfície externa da membrana celular e a partir disto, a partícula viral é endocitada, no caso dos BVs (Volkman et al., 1985) ou fusionada com a membrana, no caso dos ODVs (Horton et al., 1993). Após a endocitose dos BVs e dentro da vesícula resultante, conforme diminui o $\mathrm{pH}$, inicia a fusão de membranas do envelope viral e membrana da vesícula, esta ação é mediada pela proteína GP64, no caso dos Alphabaculovirus do Grupo I (Blissard \& Rohrmann, 1991). O capsídeo viral é 
liberado da vesícula e envelope, dentro do citoplasma celular, em seguida é carregado para o núcleo por meio de proteínas motoras via filamento de actina do hospedeiro (Ohkawa et al., 2010).

Uma vez no núcleo, fatores de transcrição do hospedeiro irão se associar ao DNA dupla fita circular, especificamente nos motivos de transcrição genéricos como TATA box (sequência TATAA) e o motivo conservado de iniciação da transcrição precoce (early) CAGT (Pullen \& Friesen, 1995). Com a associação dos fatores de transcrição ao DNA viral, a RNA polimerase II do hospedeiro inicia a transcrição dos genes da fase precoce. Muitos destes genes precoces, também chamados de genes early, são transativadores transcricionais, em especial o gene immediate early 1 ou iel, isto é, formam proteínas que irão servir de fatores de transcrição para o genoma viral, assim aumentando a transcrição dos genes virais da fase early (Hoopes \& Rohrmann, 1991), além de iniciar a montagem do sítio de replicação e montagem viral, chamado de estroma virogênico (Nagamine et al., 2005), marcando o início do controle da célula pelo vírus. 


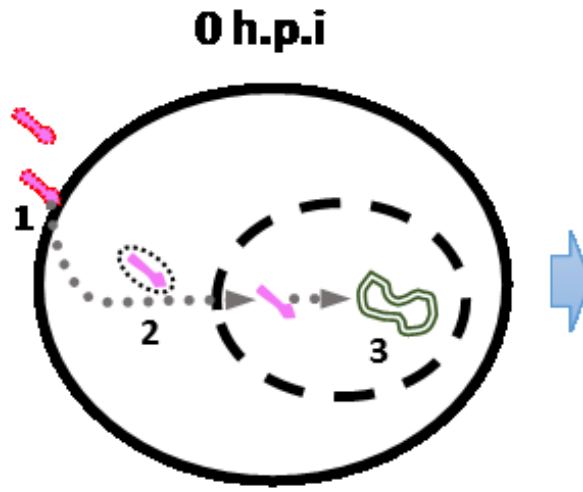

1-Aisonģöo na membrana celular 2-Entrada e tränsito ao nídeo 3-Desindamento do DilA vial

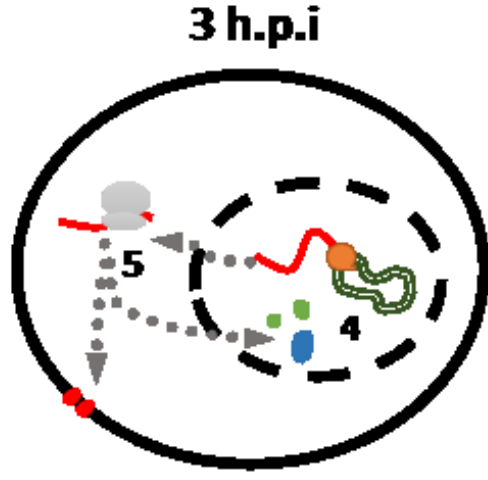

4-Transcipäo Precoce [Ris Apd II hospedeino]

5-Expressāo de genes precoces [IE1, GPG4, IEF1]

BV 12-24 h.p.i

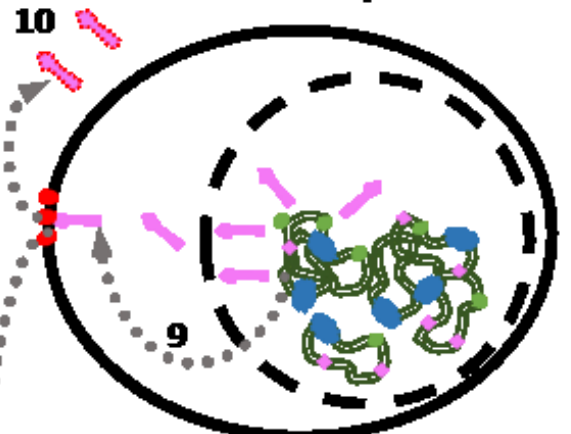

9-Träisito devíions à membrana celular 10-Ap isipaio de ervelope de mem'rana e theragoo de BVs

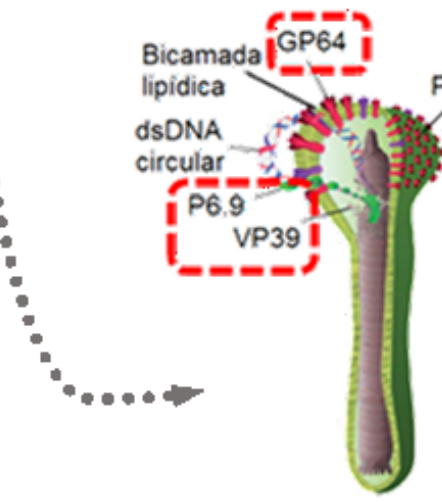

Partícula vird ervelopada responsaivel pela infecpato sistêmica [cếlla a cếl’a]
Peplómero

BV

Infeç̧̄̄o

secundária

13-Odhsāo dos ODVs na matrix protécica e formapaóo dos OBs

6 h.p.i

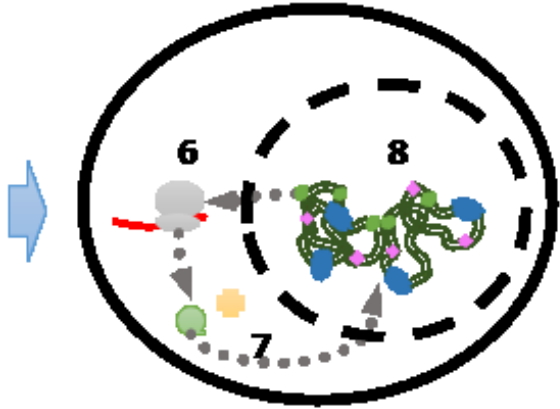

6-Expressāo dos elementos da Riv pol vird (IEF4, IEF8, IEF9, p47) 7-Translocapāo RilA pol e DuApol uris ao nícleo étício da eqpressōo de genes taríos

8-Replicapaio vial, transeripōo Taría e acímulo de proté́ias estrubrais no nídeo
11-Retengäo de víions no nícleo 12-Fonmagio de ervelope da partíala OON
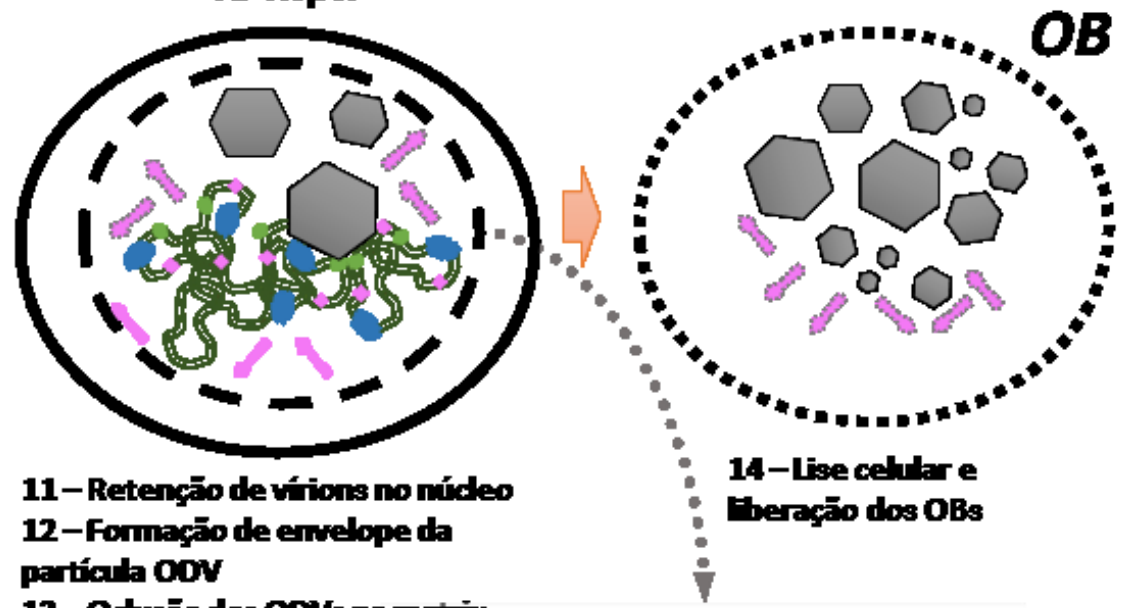

$O B$

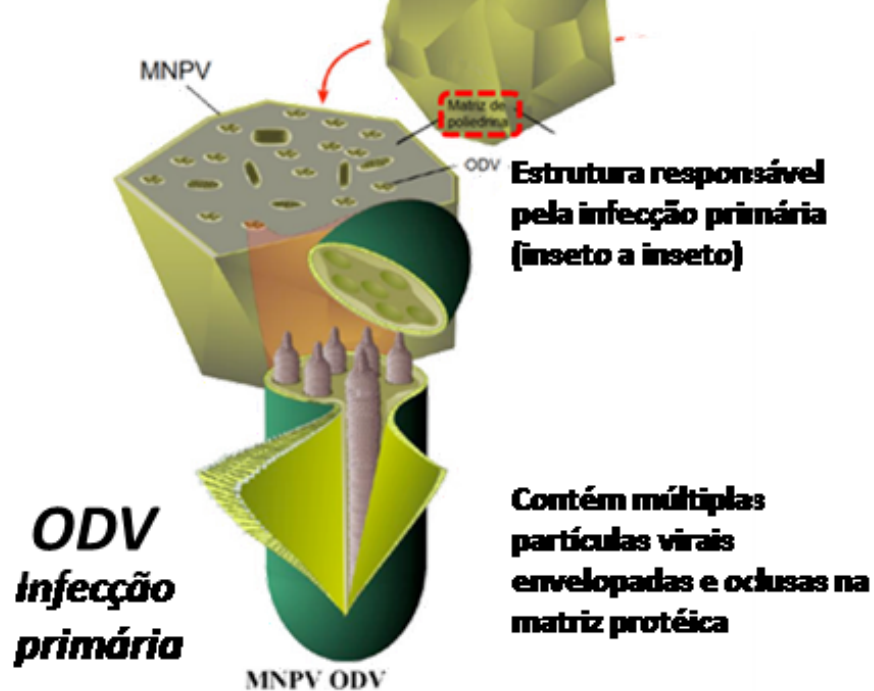

Figura 2: O progresso da infecção celular com baculovírus em linhagens celulares permissivas e os dois fenótipos gerados a partir da infecção. 
Com a expressão da DNA polimerase baculoviral e transporte desta para o núcleo, inicia-se a replicação do DNA viral e marca-se o momento de início da fase tardia ou late da infecção celular, evento que ocorre a partir das $6 \mathrm{~h}$ após a infecção celular em cultura de células de inseto (Miller, 1997). Simultaneamente, nota-se o acúmulo de proteínas LEF (late expression factor), que servem como transativadores de genes com motivos de transcrição late, em especial o motivo conservado TAAG (Todd et al, 1995; Todd et al., 1996). Uma característica especial dos baculovírus é a presença de uma holoenzima RNA polimerase viral insensível à alpha-amanitina (um composto inibidor da RNA polimerase II), composta por 4 subunidades, as proteínas derivadas dos genes LEF-8, LEF-4, LEF-9 e p47 (Guarino et al., 1998). Esta RNA polimerase viral tem forte afinidade pelo motivo de transcrição late TAAG e sequências proximais à este motivo, a especificidade e alta taxa de transcrição desta enzima garantem a intensa expressão de genes das fases tardia e de uma outra fase mais tardia, denominada de fase muito tardia ou very late (Guarino et al., 1998).

Simultâneo a replicação viral, nota-se o aparecimento de diversas proteínas baculovirais que irão moldar a célula afetando inicialmente o citoesqueleto celular (Pombo et al., 1998) e a distribuição dos cromossomos no núcleo (Nagamine et al., 2006). Pela expressão intensa dos genes virais da fase tardia, ocorre o acúmulo de proteínas virais tanto na membrana celular e no núcleo. A proteína formadora do capsídeo viral VP39, que se associa ao DNA viral no núcleo (Kawasaki et al., 2004), contribui com a formação do estroma virogênico, que se tornará a região nuclear onde ocorre a replicação do DNA viral e montagem dos capsídeos derivando a progênie viral (Pombo et al., 1998; Rohrmann, 2013). Estas partículas virais uma vez montadas são exportadas para o citoplasma e interagem com as proteínas virais associadas membrana plasmática (por 
exemplo, a proteína GP64) e então "brotam” para o exterior da célula, retendo uma parte da membrana citoplasmática como envelope viral dos BVs (Slack \& Arif, 2007).

Em momentos posteriores, o tráfego de capsídeos montados para fora do núcleo é pausado e inicia-se a montagem dos ODVs e posteriormente a oclusão em OBs dentro do núcleo (Pombo et al., 1998). Como os poliedros são cristais altamente densos, de natureza protéica, compostas pela proteína poliedrina (POLH), estima-se que pelo menos $40 \%$ de todas proteínas expressas pela célula em momentos muito tardios da infecção seja POLH (Ramachandran et al., 2001).

Em momentos muito tardios da infecção, inicia-se a hiperexpressão de genes very late ou muito tardios. Em especial observa-se o acúmulo da proteína poliedrina (POLH), que é o componente principal dos corpos de oclusão (Coullibaly et al., 2009; Ji et al., 2010). Por microscopia de luz observa-se a formação e acúmulo dos poliedros no núcleo das células infectadas após 48 h p.i. (Pombo et al., 1998).

A regulação deste processo de formação das duas partículas infectivas em momentos distintos, primeiro BV na fase tardia e depois OB na fase muito tardia, é um processo complexo que envolve a expressão sequencial e coordenada de genes (Jiang et $a l$, 2006). Os elementos cis conhecidos como os promotores gênicos são fatores determinantes do momento adequado (timing) e o nível de expressão relativa a partir do DNA viral (Todd et al., 1996). Estes são encontrados usualmente em regiões intergênicas e são compactos (Chent et al., 2013).

Os elementos principais nas sequências dos promotores precoces (figura 3 A) são: elementos TATA (25 a 31 nucleotídeos upstream da posição +1 do início da transcrição do RNA), motivos de iniciação da transcrição (INR) em especial a sequência tetranucleotídica CAGT (em média de distância de 79 pb upstream do códon iniciador ATG), regiões de elementos ativadores downstream (DAR), como a sequência CACNG 
e regiões de elementos ativadores distais upstream (UAR) como a sequência CACGTG. Entre estes, os elementos cruciais são o TATA box e INR, sendo que os promotores early podem ser classificados como contendo ambos elementos (TATA+, INR+), apenas INR (TATA-, INR+) ou apenas TATA box (Miller, 1997). Existem ainda, promotores precoces "não convencionais", como o promotor dos genes dnapol e helicase, que não contém nenhum destes elementos mas são ativados na fase precoce da infecção (Lu \& Carstens, 1991).

Estas informações sobre a sequência dos elementos DAR e UAR são referentes aos baculovírus mais estudados, como o Autographa californica MNPV (AcMNPV) e Orgyia pseudotsugata MNPV (OpMNPV). Alguns conceitos em relação aos elementos transcricionais da fase precoce entraram em disputa recentemente pela publicação do transcriptoma da infecção de $A c \mathrm{MNPV}$ em células Tn5B (Chen et al, 2013). No trabalho de Chen et al., foi feita a avaliação do sítio de início da transcrição em paralelo a quantificação dos transcritos, o que revelou que o motivo INR CAGT da fase precoce não é tão predominante quanto antecipado. Em contraposição, o elemento TATA box com distância relativa de -30 pb ao INR foi considerado essencial para a transcrição de genes da fase precoce e este determina efetivamente qual será o INR.

O elemento principal encontrado nos promotores tardios (figura 3 B) é a sequência tetranucleotídica TAAG, que é o motivo de iniciação de transcritos da RNA polimerase viral (Thiem \& Miller, 1990; Todd et al. 1996). Outros elementos a serem considerados são os elementos burst entre o INR TAAG e o códon de iniciação ATG dos promotores de genes very late, como polh, estas sequências auxiliam a hiperexpressão de genes da fase very late (Todd et al. 1996, Yang \& Miller,1999). A transcriptômica da infecção de AcMNPV em Tn5B (Chen et al, 2013) indica uma alta precisão no uso do motivo TAAG como INR de genes da fase tardia e nenhum padrão específico ao redor deste elemento. 

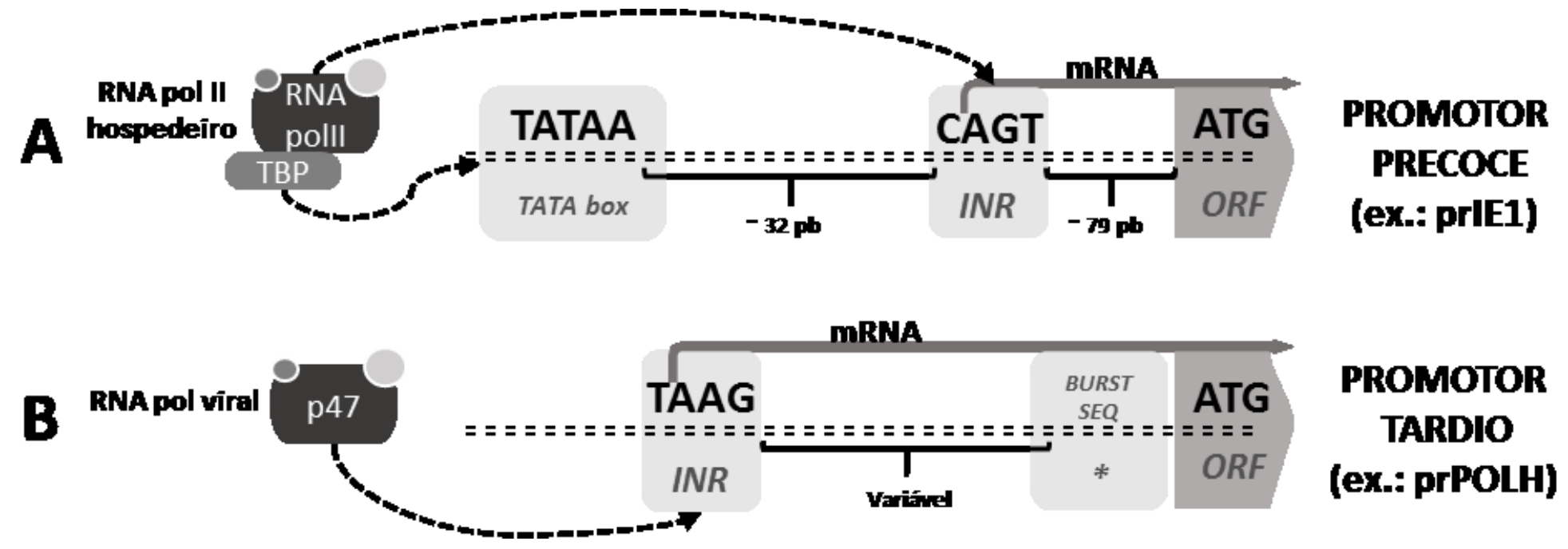

Figura 3: Estrutura do núcleo transcricional dos promotores gênicos baculovirais. Os promotores são classificados como precoces ou tardios de acordo com os elementos cis como os sítios de início da transcrição (INR) e elementos auxiliadores (TATA box) presentes nas sequências e os elementos trans que se associam as sequências e catalisam a síntese dos mRNAs. Os promotores precoces são transcritos pelo complexo transcricional RNA polimerase II e TATA box binding protein (TBP) do próprio hospedeiro enquanto os promotores tardios são transcritos pelo complexo RNA polimerase codificada por pelo menos 4 proteínas virais (LEF4, LEF5, LEF9 e p47).

A hiperexpressão gênica só é possível se o vírus estiver expressado seus genes da fase early e o hospedeiro possuir fatores de transcrição adequados para tal, muitos destes genes virais são transativadores e/ou fatores de transcrição dos genes da fase posterior, portanto é essencial existir um nível mínimo de produção de proteínas reguladoras durante o início da infecção para garantir a hiperexpressão da fase muito tardia (Ghosh et al., 1998; Morris \& Miller, 1992). Por fim, a replicação do DNA viral também é um prérequisito para a expressão de genes na fase tardia e a hiperexpressão na fase muito tardia, conforme evidência obtida no bloqueio da replicação do DNA viral com o inibidor afidicolina, que resulta em reduções drásticas na expressão de genes da fase late e very late (Glocker et al., 1993).

A infecção celular procede em uma rápida sucessão de eventos que ocorrem dentro de 24 h após a infecção (p.i.). Isto envolve o controle transcricional dos elementos virais de forma controlada, representado pelos promotores gênicos e as proteínas transativadoras do baculovírus no primeiro momento de infecção e tomada de controle 
do metabolismo celular pela atividade dos genes da fase precoce. Com o aumento no número de cópias de DNA viral molde (templates) para transcrição e a atividade transcricional exclusiva da RNA pol viral sobre os motivos de transcrição tardios, ocorre um rápido acúmulo de proteínas estruturais, para formação dos virions e proliferação da infecção pela formação de BVs e, em momentos muito tardios, a formação dos corpos de oclusão.

\subsection{Baculovírus possuem uma gama restrita de hospedeiros}

No campo, a infecção primária de insetos pelos baculovirus ocorre pela ingestão de OBs dispersos no ambiente, como em cima de folhas de soja. A matriz protéica que forma os corpos de oclusão dissolve quando exposta a uma solução alcalina e redutiva, o que ocorre no intestino médio da larva (Rohrmann, 2013). Isto resulta na liberação dos vírions contidos no OB. Estes vírus derivados de oclusão ou ODVs, são envelopados e possuem proteínas associadas à membrana que realizam funções essenciais, como a degradação da membrana peritrófica, que consiste de uma camada extracelular secretada pelas células epiteliais da mucosa do intestino da larva. Os ODVs devem ser capazes de adsorver na membrana das células epiteliais e entrar nas células, possivelmente por fusão das membranas auxiliada por proteínas virais do envelope. É essencial que ocorra a rápida infecção e produção de progênie viral na forma de BVs nestas células epiteliais do intestino, que estão sujeitas a descamação e descarte para o lúmen do intestino (Passarelli, 2011).

Após atravessar o intestino, a infecção por baculovírus deve se espalhar pelo hospedeiro, utilizando células que envolvem as traquéias e posteriormente os hemócitos contidos na hemolinfa das larvas. Estas últimas estão em circulação livre pela hemolinfa, e portanto servem como perfeitos proliferadores da infecção sistêmica baculoviral (Soares 
\& Ribeiro, 2005). Após 5 dias de infecção, a larva apresenta letargia e paralisia. Análise de tecidos por microscopia de luz indica grande acúmulo de poliedros em tecidos específicos, como nas células de gordura, hemócitos e células traqueolares. Em contraposição, alguns tecidos da larva não produzem OBs, mesmo infectados, como as células do intestino e dos túbulos de Malpighi (Soares \& Ribeiro, 2005; Passarelli, 2011; Rohrmann, 2013).

Uma característica comum a diversas espécies de baculovírus é o restrito espectro de hospedeiros que cada vírus é capaz de infectar oralmente. Como descrito anteriormente, a família Baculoviridae está limitada à infecção de larvas de insetos das ordens Lepidoptera e poucas espécies que infectam insetos da ordem Diptera e Hymenoptera (Jehle et al, 2006). Além disso, os baculovírus, que são usados como bioinseticidas em larga escala, já foram demonstrados não infectar as demais ordens de insetos, animais e plantas, encontrados nos campos aplicados (Ashour et al, 2007). Desta forma, afirma-se que os baculovírus são bioinseticidas ecologicamente seguros em comparação aos inseticidas químicos cujos mecanismos de ação são genéricos à insetos de diversas famílias e outros organismos.

A observação do espectro restrito de hospedeiros de cada baculovírus está baseada em ensaios de infecção oral utilizando OBs em diferentes espécies de larvas de lepidópteros, o que revelou que espécies próximas filogeneticamente e comumente cocoletadas na mesma espécie vegetal predada, muitas vezes possuem suscetibilidades opostas, uma espécie facilmente infectada com pequenas doses enquanto a outra exige doses milhares de vezes mais altas para induzir a morte. Esta limitação da infecção primária por algumas espécies está associada tanto a mecanismos de defesa das larvas, entre estas, barreiras físicas (membrana peritrófica) do intestino que impedem o acesso das partículas virais à células da mucosa do intestino (Abot et al, 1996; Levy et al, 2009, 
2011), proteínas neutralizantes das partículas virais (Choi et al, 2012) e a capacidade de descamar rapidamente as células infectadas no intestino assim "limpando" a infecção antes da proliferação sistêmica (Haas-Stapleton et al, 2005; Asser-Kaiser et al, 2011). Em paralelo, os baculovírus possuem genes voltados à combater estas defesas pela aceleração da infecção viral sistêmica através de proteases capazes de danificar a membrana peritrófica (Gallo et al, 1991), a transcrição imediatamente precoce de genes estruturais e a expressão precoce de proteínas remodeladoras (vFGF) da lâmina basal de células epiteliais colunares do intestino (Passarelli, 2011). Além disso, o envelope dos ODVs contem múltiplos vírions (Washburn et al, 2003; 2009), o que garante rápida transmissão da infecção das células da mucosa às células da hemolinfa ou traqueoblastos acelerando a infecção sistêmica (Engelhard et al, 1994; Passarelli, 2011).

A infecção de células de Lepidoptera cultivadas in vitro revelou mecanismos celulares de defesa à infecção por baculovírus. A apoptose ou morte celular programada induzida pela expressão de genes baculovirais ocorre no caso de algumas combinações de baculovírus e certas linhagens. Alguns genes baculovirais já foram comprovados como efetivos fatores anti-apoptóticos, por exemplo, o gene $p 35$ de AcMNPV (Mehrabadi et al., 2015) e o gene iap3 de $A g M N P V$ (Carpes et al, 2005). No entanto estes genes não são funcionais contra todas linhagens celulares indicando que a restrição de infectividade celular também possui especificidades. Em contrapartida, a proteína de membrana GP64 presente em BVs de Alphabaculovirus do grupo I, possui uma atividade de fusão de membranas em células cultivadas in vitro aparentemente independente de receptores específicos de insetos, o que permite que BVs de baculovírus entrem em linhagens celulares de diversos tipos e espécies, até mesmo de células de mamíferos (Ghosh et al, 2002). 
Desta forma, o sucesso da infecção por baculovírus tanto in vivo quanto in vitro está relacionado à múltiplos eventos e interações que envolvem desde o acesso físico dos vírions ao núcleo de células suscetíveis, a capacidade de manipular o metabolismo celular, estabelecer uma infecção produtiva em termos de replicação do vírus e formação de progênie viral infectiva. Neste sentido, a investigação dos mecanismos de suscetibilidade à infecção por linhagens celulares possui muitas áreas de estudos possíveis e este trabalho abordará o que ocorre em nível de controle transcricional durante a infecção de células suscetíveis e não suscetíveis. Como os promotores baculovirais estão associados aos diferentes eventos sequenciais da infecção celular, é possível utilizar os perfis de atividade dos promotores de diversas classes como "sondas" que informam o progresso ou falha da infecção em determinados momentos, de acordo com a suscetibilidade da linhagem celular.

O baculovírus $A g \mathrm{MNPV}$ é facilmente manipulado e amplificado devido à disponibilidade de linhagens celulares derivadas de inseto imortalizadas que são capazes de propagar este vírus. A linhagem celular derivada de larvas Anticarsia gemmatalis, denominada UFL-AG-286 ou comumente UFLAg (Sieburth \& Maruniak, 1988), produz altos títulos de BVs após 12 h de infecção com o vírus $A g M N P V$ (Castro et al., 1997). A infecção causa mudanças estruturais nestas células nas primeiras $24 \mathrm{~h}$, identificados como efeitos citopáticos e observados por microscopia de luz, como o arredondamento da célula, hipertrofia do núcleo e perda de extensões citoplasmáticas, além da evidente aparição dos corpos de oclusão no núcleo após 48 h p.i. (Pombo et al., 1998). O meio de cultura retém os BVs infectivos e este meio é utilizado como inóculo viral para infecções in vitro posteriores.

Outras linhagens também são infectadas pelo baculovírus $A g \mathrm{MNPV}$, como a linhagem derivada de larvas T. ni BTI-Tn5B1-4 (Tn5B), cuja produtividade da infecção 
é similar a infecção de células UFL-AG-286 (UFLAg), em nível de tradução de proteínas, replicação de DNA viral e produção de BVs e OBs infectivos (Castro \& Ribeiro, 2001). As linhagens de células derivadas de larvas da espécie $S$. frugiperda denominadas de IPLB-SF21-AE (Sf21) e a linhagem derivada Sf9, que são suscetíveis a infecção por $A g \mathrm{MNPV}$, com reduzida replicação de DNA viral, e consequentemente menor produção de BVs e OBs, e assim são consideradas semipermissivas a infecção (Castro et al., 1997).

Existem linhagens não permissivas à infecção do vírus $A g \mathrm{MNPV}$, que por definição, são linhagens em que a infecção viral não replica DNA e/ou não gera progênie infectiva (Morris \& Miller, 1994). Usualmente os efeitos citopáticos iniciais conflagram a morte celular programada ou apoptose, como ocorre na linhagem Bm5 derivada de Bombyx mori, o bicho da seda. Outras linhagens podem ser suscetíveis à entrada e infecção inicial, mas resultam em baixa progênie viral e nenhuma produção de corpos de oclusão. Isto ocorre com a linhagem IPRI-CF-124T, derivada de larvas da espécie Choristoneura fumiferana, que aparentemente bloqueia o progresso da infecção de AgMNPV (Castro et al., 1997). Os mecanismos moleculares de bloqueio ou suscetibilidade da infecção de baculovírus pela célula hospedeira são variados e em grande parte desconhecidos.

O baculovírus $A c \mathrm{MNPV}$, como descrito anteriormente, é o mais estudado e utilizado entre todas as espécies conhecidas até o momento e é considerado um vírus de amplo espectro de hospedeiros in vivo e in vitro (Rohrmann, 2013). O seu uso como vetor comercial de expressão de proteínas heterólogas (BEVS, Baculovirus Expression Vector System) é uma prova disso. Este sistema tem como base, a manipulação do baculovírus e uso deste em células de inseto suscetíveis a infecção para produzir proteínas de interesse. O próprio manual do BEVS sugere o uso das linhagens Sf9 para a produção de um alto título viral e a linhagem Tn5B como "fábrica" de produção de proteínas. Estas linhagens 
são consideradas permissivas ao $A c \mathrm{MNPV}$ devido à alta produção de partículas virais (Bonning et al., 1995; Iwanaga et al., 2004a).

O vírus AcMNPV tem baixa letalidade para larvas $A$. gemmatalis após a infecção oral, resultando em baixa produção de BVs na hemolinfa mas alta expressão do gene precoce-tardio vp39 (Chikhalya et al., 2009). Estudos do nosso laboratório com AcMNPV recombinante contendo inibidor do silenciamento gênico NSs do tospovírus TSWV revelaram que este gene é capaz de aumentar a replicação, expressão gênica em hemócitos e a letalidade para as larvas $A$. gemmatalis, potencialmente combatendo mecanismos de defesa celular por silenciamento da transcrição de genes virais (de Oliveira et al., 2015; Oliveira et al., 2011).

A infecção em Ld652Y já foi bem explorada e a célula é considerada nãopermissiva. A observação original foi que após infecção não ocorre apoptose, existe baixa produção de BVs e nenhuma produção de OBs (Morris \& Miller, 1993, 1992) mesmo ocorrendo altos índices de transcrição gênica (Guzo et al., 1992), o que levantou a hipótese de que a infecção nesta célula é abortiva devido ao bloqueio de produção de proteínas. A adição do gene da fase precoce hrf-1 (host range factor 1) do baculovírus Limantria dispar MNPV (Du \& Thiem, 1997) ao AcMNPV foi capaz de resgatar a alta replicação e aumentar a expressão gênica, quebrando o bloqueio na síntese de proteínas virais (Thiem et al., 1996). Um AcMNPV com knockout do gene anti-apoptótico p35 não induz bloqueio na tradução. Como este evento inicia em momentos precoces e aumenta com a replicação do vírus, é sugestivo que a supressão da apoptose induz o bloqueio na tradução como segunda via alternativa a apoptose para inibir a proliferação do vírus (Thiem \& Chejanovsky, 2004). A infecção de AcMNPV na linhagem Chch derivada de Chrysodeixes chalcites é considerada não-permissiva e resulta em apoptose. Esta linhagem apenas é permissiva aos Alfabaculovírus do grupo II como o Trichoplusia ni 
SNPV e Chrysodeixes chalcites SNPV (Xu et al., 2012). A linhagem Bm5 também não é permissiva pois não ocorre replicação do vírus AcMNPV wild-type. Mutações específicas no gene helicase do AcMNPV são capazes de resgatar a capacidade de replicação do vírus nessas células (Argaud et al., 1998). Apenas os NPVs derivados de Bombyx mori e $B$. mandarina são capazes de infectar Bm5, enquanto estes vírus não infectam a linhagem Sf9, permissiva ao AcMNPV (Xu et al., 2012).

O $A c \mathrm{MNPV}$ e o $A g \mathrm{MNPV}$ possuem um espectro de hospedeiro que se sobrepõem. Ambas são infectivas a Tn5B, no entanto, a infectividade sobre as linhagens Sf9 e UFLAg aparentemente são opostas. Ambos vírus são incapazes de produzir progênie em Bm5 e induzem infecções abortivas em Ld652Y sem produção de OBs e em Chch sem produção de OBs induzindo apoptose. Uma comparação direta entre a expressão gênica dos promotores de cada vírus em diversas fases da infecção deve render mais informações que permitam identificar os mecanismos que regulam a permissividade celular à infecção.

\subsection{Trabalhos anteriores do estudo da atividade de promotores do $\mathrm{AgMNPV}$}

Em trabalhos anteriores do nosso grupo de trabalho (Morgado, 2012), promotores gênicos do baculovírus $A g \mathrm{MNPV}$ foram isolados por PCR e subclonados upstream do gene repórter Firefly luciferase (Luciferase de vagalume, fluc) em plasmídeos de transferência contendo uma região de 2100 pb do locus do gene polh de AgMNPV. A partir destes, foram construídos baculovírus $A g \mathrm{MNPV}$ recombinantes por recombinação homóloga em células de inseto (vAgIE1FLUC, vAgGP64FLUC, vAgLEF1FLUC, vAgVP39FLUC, vAgP6.9FLUC e vAgPOLHFLUC, figura 4). Estes foram utilizados no desenvolvimento de uma nova técnica de detecção da atividade quimioluminescente de FLUC em tempo real (Morgado, 2012). Os resultados obtidos por esta técnica permitiram avaliar a função dos promotores durante a infecção celular em tempo real com alta 
resolução, no entanto o equipamento utilizado anteriormente não permitia a automatização do procedimento e apresentava alta variabilidade. Pela aquisição do luminômetro de placa Glomax 96 (Promega) foi possível resolver estas questões técnicas e refazer os experimentos que são apresentados neste trabalho, . Além disto, experimentos foram realizados variando parâmetros essenciais à infecção celular e eficiência da expressão de genes heterólogos como a Multiplicidade de Infecção (MOI) e o número de células infectadas no início da infecção.

Utilizando estes baculovírus recombinantes da espécie $A g \mathrm{MNPV}$ em comparação aos recombinantes equivalentes da espécie $A c \mathrm{MNPV}$, construídos neste trabalho, foi possível obter dados inéditos de expressão gênica diferencial destes vírus e seus promotores com espectros específicos e distintos de hospedeiros.

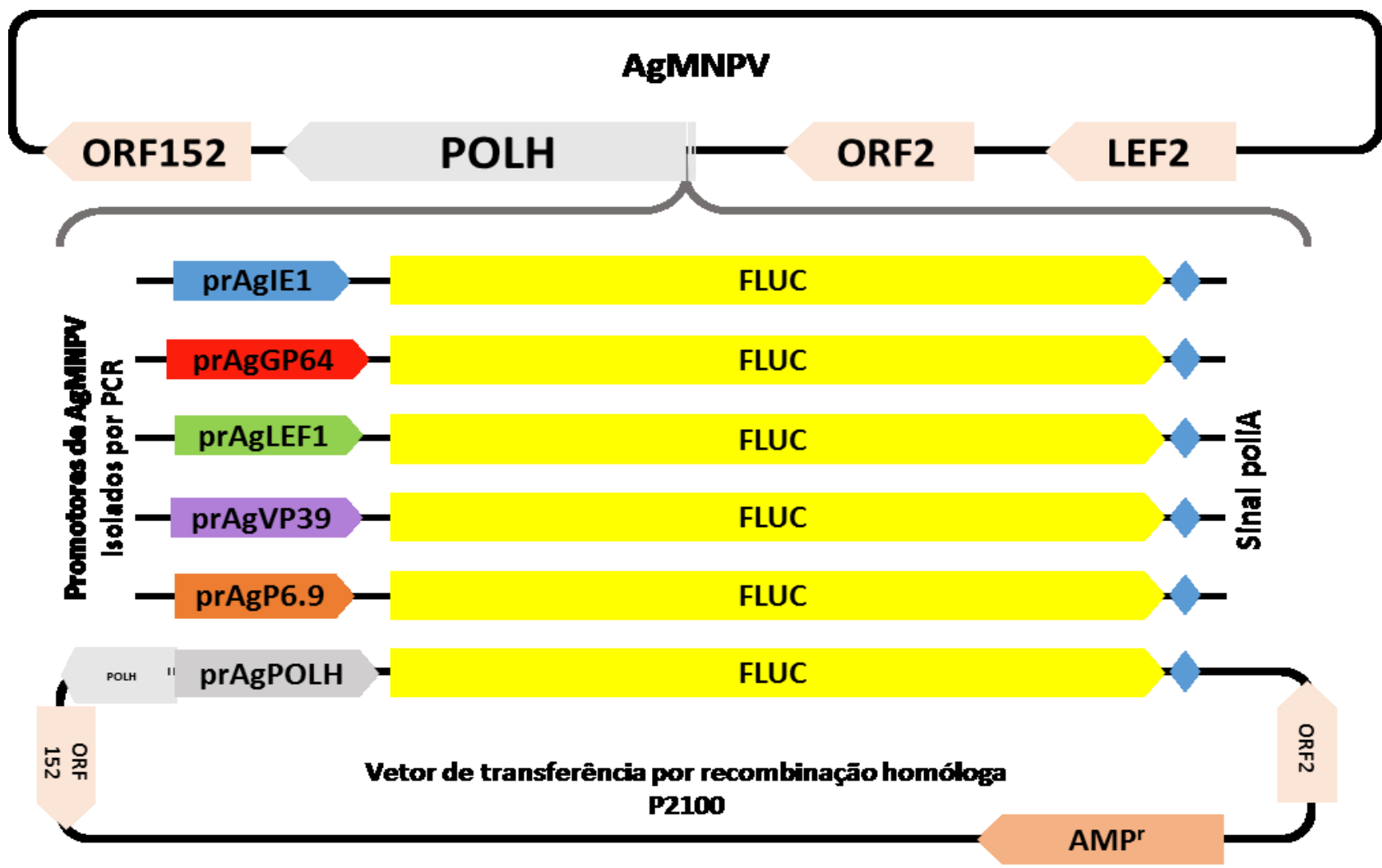

Figura 4: Diagrama delineando o procedimento de construção dos baculovírus AgMNPV recombinantes por recombinação homóloga. Acima uma representação do genoma de $A g M N P V$ e o locus do gene polh e genes que o flanqueiam. Abaixo uma representação do plasmídeo de transferência p2100 (Cordeiro et al,, 2008) que contém parte do locus do gene polh onde foram clonados o gene fluc e a montante deste os diferentes promotores derivados de $A g M N P V$. Cada plasmídeo foi utilizado na construção de um baculovírus AgMNPV recombinante respectivo por recombinação homóloga em células de inseto (Morgado, 2012). 


\subsection{A interação simbiótica e biologia do bracovírus Microplitis demolitor BV e seu hospedeiro a vespa Microplitis demolitor}

A vespa australiana Microplitis demolito pertence a ordem Hymenoptera, família Braconidae, subfamília Microgastrinae (Shepard et al., 1983). O grupo Microgastrinae possui até 10.000 espécies de vespas parasitas com distribuição mundial (FernándezTriana, 2010; Yu et al., 2005). São espécies que quando adultos vivem com hábitos solitários e injetam seus ovos em outros insetos como em larvas de Lepidoptera. Por exemplo, M. demolitor parasita naturalmente as larvas de Helicoverpa punctigera, mas também é capaz de parasitar Helicoverpa armigera e Chrysodeixes includens (Burke et al., 2016). Estes ovos eclodem e as larvas vivem dentro do hospedeiro, consumindo nutrientes da hemolinfa. As larvas saem do corpo do hospedeiro aproximadamente 10 dias após eclosão (Strand \& Burke, 2012) e imediatamente tecem um casulo ao seu redor utilizando glândulas secretoras de seda. Dentro do casulo inicia-se a metamorfose e formação do indivíduo maduro e alado. Após cruzamento entre adultos macho e fêmea, reinicia-se o ciclo com um novo parasitismo de larvas de Lepidoptera.

Durante o parasitismo de larvas Lepidoptera (figura 5), alguns mecanismos de defesa foram identificados, que inibem a eclosão dos ovos por encapsulamento celular de granulócitos (Davies \& Vinson, 1988; Strand et al., 2006) ou pela via profenoloxidase que permite a neutralização de patógenos pela polimerização de quinonas na forma de melanina que encapsula o patógeno ou parasita, além de auxiliar no fechamento de feridas (Beck \& Strand, 2007). Estes são mecanismos envolvidos no controle do parasitismo das vespas pelo hospedeiro, reduzindo a sobrevivência das larvas e ovos que o parasitam.

Dentro da espécie $M$. demolitor existe um Bracovírus endógeno, da família Polydnaviridae, denominado MdBV (Microplitis demolitor Bracovirus). O genoma deste 
vírus tem um tamanho de 189.000 pares de bases $(\mathrm{pb})$ dividido entre 15 segmentos de DNA dispersos em diferentes cromossomos que codificam 61 genes. Nem todos segmentos genômicos são amplificados e encapsidados (Burke \& Strand, 2012; Burke et al., 2014, 2013). Os PDVs (PolyDNAvirus) são compostos por dois grupos, os Bracovirus contidos em vespas da família Braconidae; e os Ichnovirus, contidos em vespas da família Ichneumoidea. Estes vírus tem como ancestral um Nudivirus que se integrou no genoma de um ancestral de vespa aproximadamente 190 milhões de anos atrás em eventos de duplo parasitismo do Nudivirus e da vespa sobre uma mesma larva Lepidoptera (Bézier et al., 2009). Após a integração, o vírus se tornou endógeno e dependente da vespa hospedeira para sua continuidade. Em seguida, tornou-se simbionte ao evoluir no sentido de promover o parasitismo da vespa sobre larvas de Lepidoptera pela supressão do sistema imune destes últimos (Dupas et al., 2008) e reduzir qualquer efeito negativo do próprio Bracovírus que poderia exercer sobre as vespas hospedeiras (Dupuy et al., 2006). A integração teve consequências sobre a topologia do genoma viral. Os Nudivirus são vírus extracelulares com genoma circular de DNA dupla fita com alta densidade gênica e pouca distância intergênica enquanto os PDVs possuem genomas segmentados e integrados em diversos cromossomos da vespa hospedeira (Annaheim \& Lanzrein, 2007; Burke et al., 2014, 2013). Além disso, genes presentes em todos Nudivirus estão ausentes em PDVs enquanto os que foram preservados sofreram alterações na coordenação de sua expressão e mutações em suas sequências (Strand \& Burke, 2012). Desta forma, o vírus tornou-se útil para a vespa, sendo agora um simbionte obrigatório, que o retêm como hospedeira e a evolução do genoma viral dentro da vespa tornou-se permanentemente ligada ao fitness do parasitismo da vespa sobre o hospedeiro (Burke \& Strand, 2012; Cui et al., 2000; Strand \& Burke, 2013). 
Os PDVs replicam a partir do DNA proviral apenas em células específicas do ovário de vespas adultas fêmeas, as células do cálice. O início da replicação ocorre entre o período final da pupa e ínstars iniciais da fase adulta (Burke \& Strand, 2012; Norton \& Vinson, 1983) e é caracterizada pela excisão e amplificação de segmentos de DNA viral que serão circularizados e encapsidados. Estes segmentos comumente são chamados de "genoma encapsidado" enquanto os demais segmentos são chamados de "genoma nãoencapsidado" (Burke \& Strand, 2012; Drezen et al., 2003; Kroemer \& Webb, 2004). A maior parte dos segmentos do genoma não-encapsidado contém os genes responsáveis pela transcrição, replicação e proteínas estruturais que formam os capsídeos (Burke \& Strand, 2012; Gruber et al., 1996), enquanto os segmentos do genoma encapsidado contém genes responsáveis pelo controle da larva hospedeira durante o parasitismo da vespa (Burke \& Strand, 2014; Cui et al., 2000; Strand et al., 1997; Trudeau et al., 2000; Weber et al., 2007). Os capsídeos são liberados no lumen do útero e no momento de injeção dos ovos e veneno (Asgari, 2006) na hemolinfa do hospedeiro Lepidoptera as partículas virais também são injetadas (Shepard et al., 1983; Vinson \& Scott, 1975; Wyler \& Lanzrein, 2003).

É importante realizar uma comparação do programa de transcrição dos PDVs com demais vírus, em especial os NPVs. A definição comum é que os genes virais transcritos antes da replicação fazem parte da fase precoce, usualmente expressam proteínas responsáveis pela formação do complexo de replicação do DNA viral e montagem dos capsídeos (Bézier et al., 2009), sendo comum também a expressão de fatores de transcrição (transativadores) que promovem maior expressão gênica. O PDV $M d \mathrm{BV}$ também possui e expressa em fases precoces os genes análogos à RNA polimerase dos Baculovírus, composta pelas proteínas LEF4, LEF5, LEF9 e p47 (Burke \& Strand, 2012; Burke et al., 2013). Acredita-se que esta RNA pol viral transcreve genes estruturais com 
alta eficiência e possui afinidade pelos promotores destes genes, de forma similar aos NPVs. A evidência para isto é indireta, baseada na quantificação do mRNA de genes estruturais que indicou uma expressão muito maior destes genes que os demais (Bézier et al., 2009b; Burke \& Strand, 2012; Burke et al., 2013; Cui \& Webb, 1998). Ainda não são conhecidos os alvos da RNA pol viral ou se esta realmente é a responsável pela transcrição tardia. A fase tardia da infecção segue com a formação e liberação das partículas virais como descrito.

Apenas o tecido chamado de cálice dentro do ovário da fêmea é capaz de expressar os genes de $M d \mathrm{BV}$ e efetivamente formar partículas virais. O resto do corpo da vespa tem uma expressão negligencial (Gruber et al., 1996). É importante ressaltar que os PDVs não 'infectam' as células da vespa, portanto a descrição da formação das partículas virais como o progresso de uma infecção viral é uma expressão incorreta, que pode ser utilizada apenas para facilitar a descrição por ter como referência o conhecimento de demais vírus. A verdadeira infecção realizada pelo $M d \mathrm{BV}$ ocorre no corpo da larva Lepidoptera a partir dos vírions injetados junto do ovo da vespa. Para ficar mais claro, é possível separar as 'fases' de transcrição dos PDVs em três momentos: as fases precoce e tardia que ocorrem dentro da do útero de vespas e uma terceira 'fase' que ocorre dentro de células da larva Lepidoptera durante o parasitismo da vespa.

Dentro da hemolinfa, as partículas virais entram em tecidos celulares e células livres da hemolinfa, penetram no núcleo celular e são transcritas pelo maquinário celular (Strand, 1994). Além da própria partícula viral possuir em sua membrana proteínas que atuam imediatamente sobre o hospedeiro (Burke \& Strand, 2014). Não ocorre replicação ou formação de novas partículas virais durante a infecção de células Lepidoptera. Os segmentos encapsidados não contém genes estruturais ou auxiliares da replicação (Webb et al., 2006). Mesmo sem replicação, foi observado que existe uma longa persistência (1 
a 2 semanas) da expressão de genes de MdBV a partir destas partículas virais nas células da lagarta hospedeira (Le et al., 2003; Strand et al., 1992). Esta persistência ocorre pois os segmentos de DNA viral são integrados no genoma das células de Lepidoptera (Gundersen-Rindal \& Lynn, 2003). Em plasmócitos, principais reguladores da resposta imune na hemolinfa, a expressão gênica a partir dos $M d \mathrm{BV}$ s promove apoptose (Strand \& Pech, 1995).

Os granulócitos, células responsáveis pela encapsulação (Strand et al., 2006), fagocitose e neutralização de corpos invasores na hemolinfa pela secreção de proteínas ativadoras de profenoloxidase (PAPs), tem a transcrição deste gene afetada negativamente pela infecção por PDVs (Barat-Houari et al., 2006). Além disto, ocorre a inativação das enzimas PAPs pela proteína do capsídeo $M d \mathrm{BV}$ chamada de EGF1.0 (Beck \& Strand, 2007). Além disto, a proteína GLC1.8, presente nas partículas virais, inibe a capacidade de fagocitose e aderência dos granulócitos (Strand et al., 2006). Os PDVs também são capazes de afetar o sistema hormonal da larva Lepidoptera, evitando que esta última entre no estágio pré-pupa, o que resultaria no início da metamorfose o que acaba por matar as larvas e ovos de vespas que a parasitam (Weber et al., 2007). Todos estes eventos garantem a imunossupressão do hospedeiro e aumentam consideravelmente as chances de sobrevivência das larvas de vespa dentro das lagartas. 


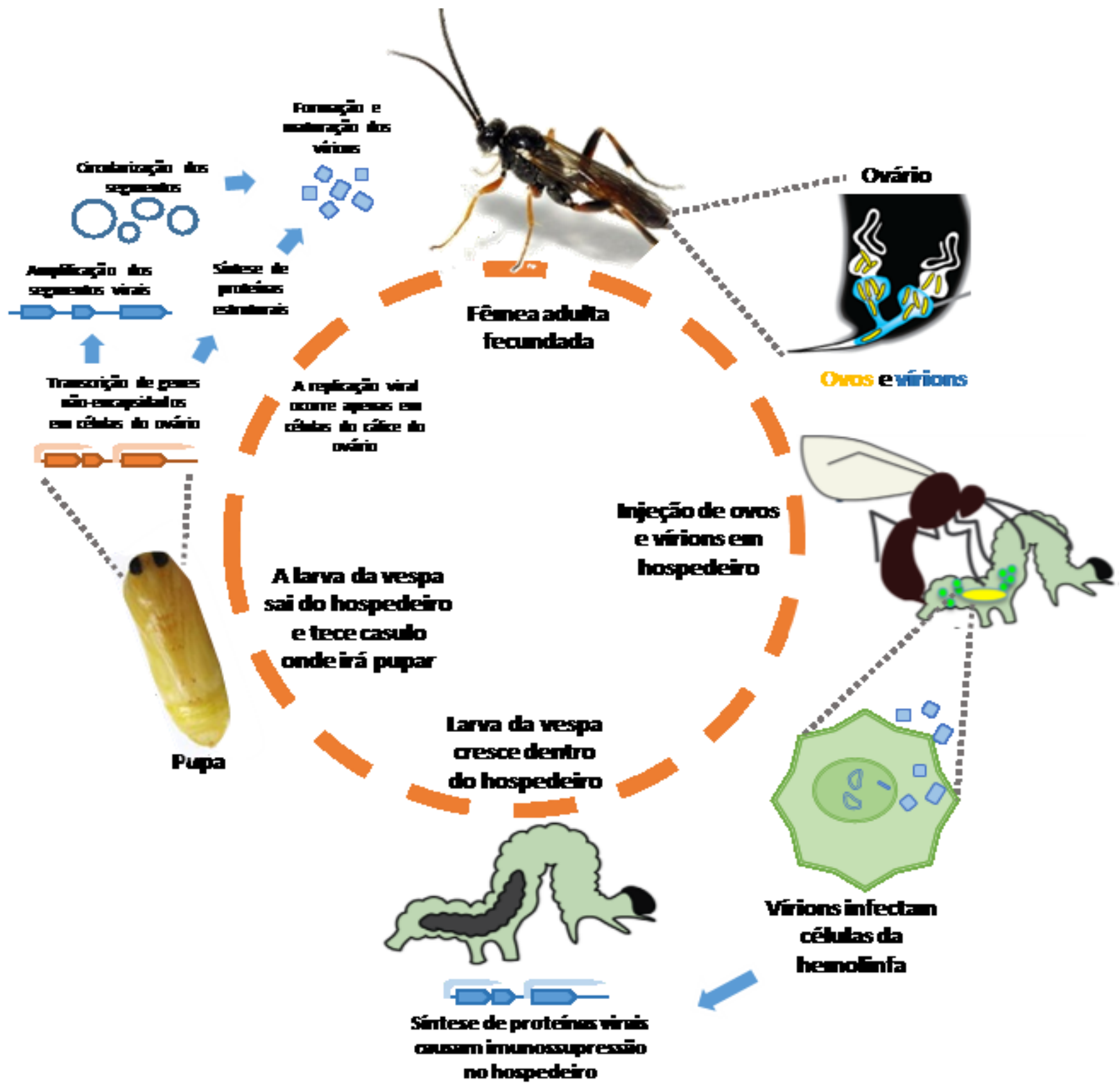

Figura 5: 0 ciclo de vida das vespas parasitas Braconidae ou Ichneumoidae e o parasitismo sobre larvas da ordem Lepidoptera. Em paralelo ao ciclo de vida da vespa ocorre a produção de partículas virais do PolyDNAvirus integrado no genoma da vespa que são injetados junto com os ovos durante o parasitismo e serão úteis no controle da lagarta hospedeira pela vespa.

Poucos estudos foram realizados de manipulação dos promotores gênicos do $M d \mathrm{BV}$. O foco ocorreu nos promotores dos genes encapsidados, aqueles que efetivamente serão expressos nas lagartas hospedeiras. Foi demonstrado que estes são ativados pelas células derivadas de Lepidoptera tanto a partir da infecção com baculovírus ou quando 
são transfectados em plasmídeos contendo gene repórter (Asgari \& Schmidt, 2001; Hepat \& Kim, 2012; Hepat et al., 2013). Até o momento nenhum estudo foi realizado manipulando os promotores de genes não-encapsidados. Praticamente todo conhecimento sobre a expressão gênico do $M d \mathrm{BV}$ em qualquer de seus momentos é derivado de transcriptomas do parasitismo em lagartas (Barat-Houari et al., 2006; Burke \& Strand, 2014; Chevignon et al., 2014; Cui et al., 2000; Weber et al., 2007) ou transcriptomas de diferentes estágios de desenvolvimento da vespa (Burke \& Strand, 2012; Drezen et al., 2003).

O estudo destes promotores expressos apenas em vespas (de genes nãoencapsidados) pode revelar questões de grande importância na compreensão da biologia destes organismos e suas complexas interações. Ainda precisamos compreender como funcionam os mecanismos de controle da expressão gênica específicamente no ovário nestas espécies. Como ocorreu a evolução deste controle após a dispersão dos segmentos genômicos dentro de diversos cromossomos da vespa? Como e qual agente promove a ativação dos promotores de genes da fase precoce? Como ocorre a hiperexpressão dos genes da fase tardia? Uma das razões pelas quais existem poucos estudos de manipulação destes elementos de transcrição é devido a falta de modelos experimentais viáveis que permitam avaliar a atividade deste no contexto da vespa. Isto é, necessitamos de uma linhagem celular derivada de vespa que permita realizar estes estudos ou pelo menos um sistema equivalente. 


\section{JUSTIFICATIVA E OBJETIVOS}

O controle temporal da expressão gênica durante a infecção por baculovírus é primariamente determinado pelos promotores gênicos, estes elementos são representantes do programa de infecção viral que podem ser estudados e avaliados em diferentes condições para compreender seu funcionamento, ou em uma análise em conjunto compreender o próprio programa da infecção viral e a conservação deste em diferentes espécies de vírus e linhagens celulares. A atividade de promotores gênicos no contexto do programa transcricional das diferentes condições celulares de infecção (permissivas a não-permissivas) pode nos revelar importantes informações sobre as defesas celulares anti-virais e artifícios virais contra estas defesas.

Portanto o foco deste trabalho foi a investigação da expressão gênica e os elementos controladores da transcrição durante a infecção celular com baculovírus recombinantes em diversas linhagens celulares utilizando o método de detecção de luminescência em tempo real. O fluxograma 1 descreve os processos realizados nesta investigação.

Uma parte do trabalho relacionada aos promotores de $M d \mathrm{BV}$ foi desenvolvida durante um doutorado sanduíche financiado pela CAPES que foi conduzido na Universidade da Geórgia (UGA) nos Estados Unidos da América, no laboratório do dr. Michael R. Strand (Departamento de Entomologia). Os objetivos deste trabalho foram avaliar os promotores de genes não-encapsidados do bracovírus $M d \mathrm{BV}$ quando clonados no baculovírus $A c \mathrm{MNPV}$ e utilizar estes recombinantes para avaliar a habilidade do AcMNPV em transduzir a linhagem MdE (derivada de M. demolitor). Os processos deste trabalho estão dispostos no fluxograma 2. 


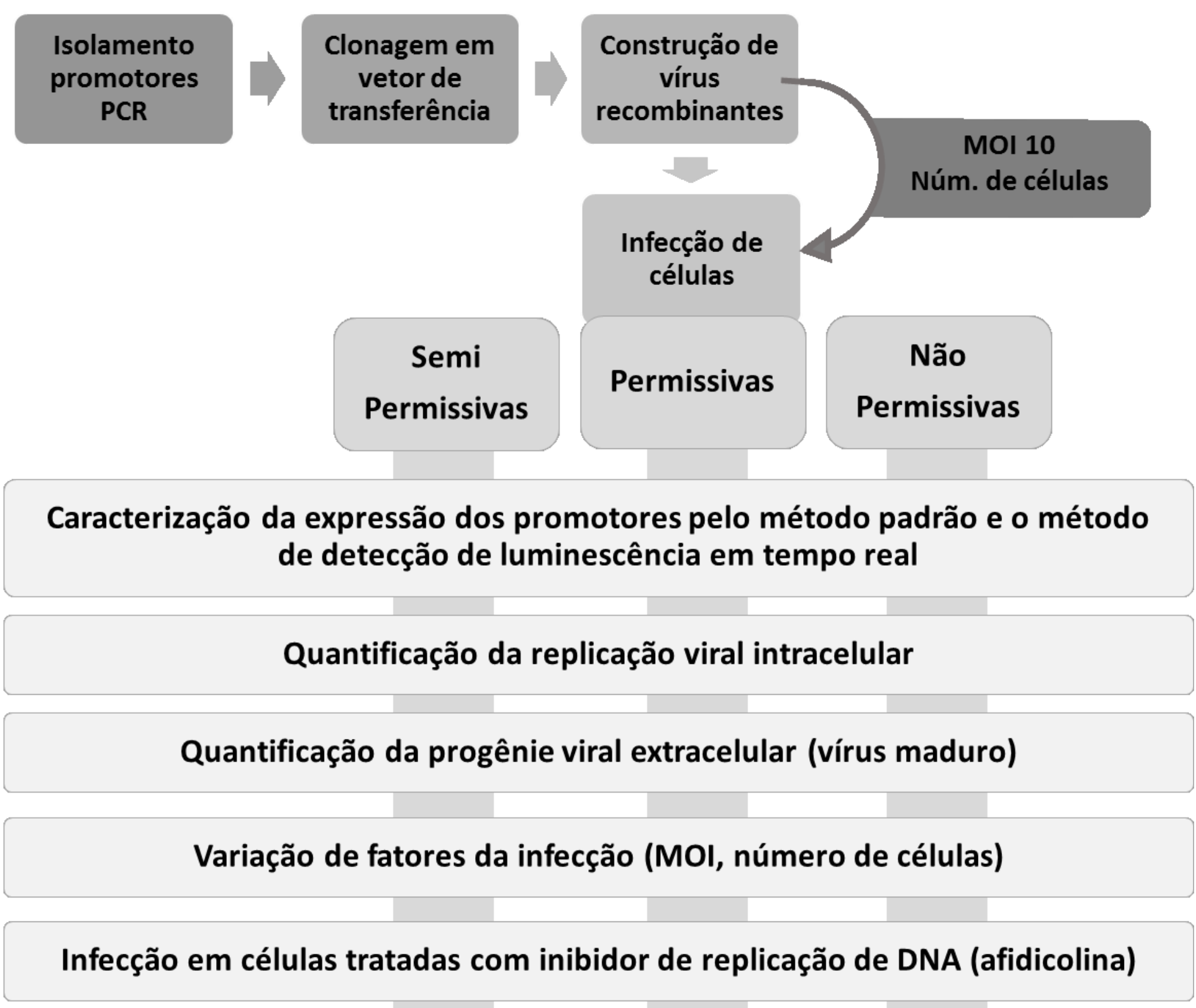

Fluxograma 1: Descrição geral dos procedimentos e materiais utilizados para estudar as infecções dos baculovírus recombinantes AgMNPV e AcMNPV contendo promotores virais derivados de AgMNPV ou AcMNPV regulando o gene repórter quimioluminescente fluc. 


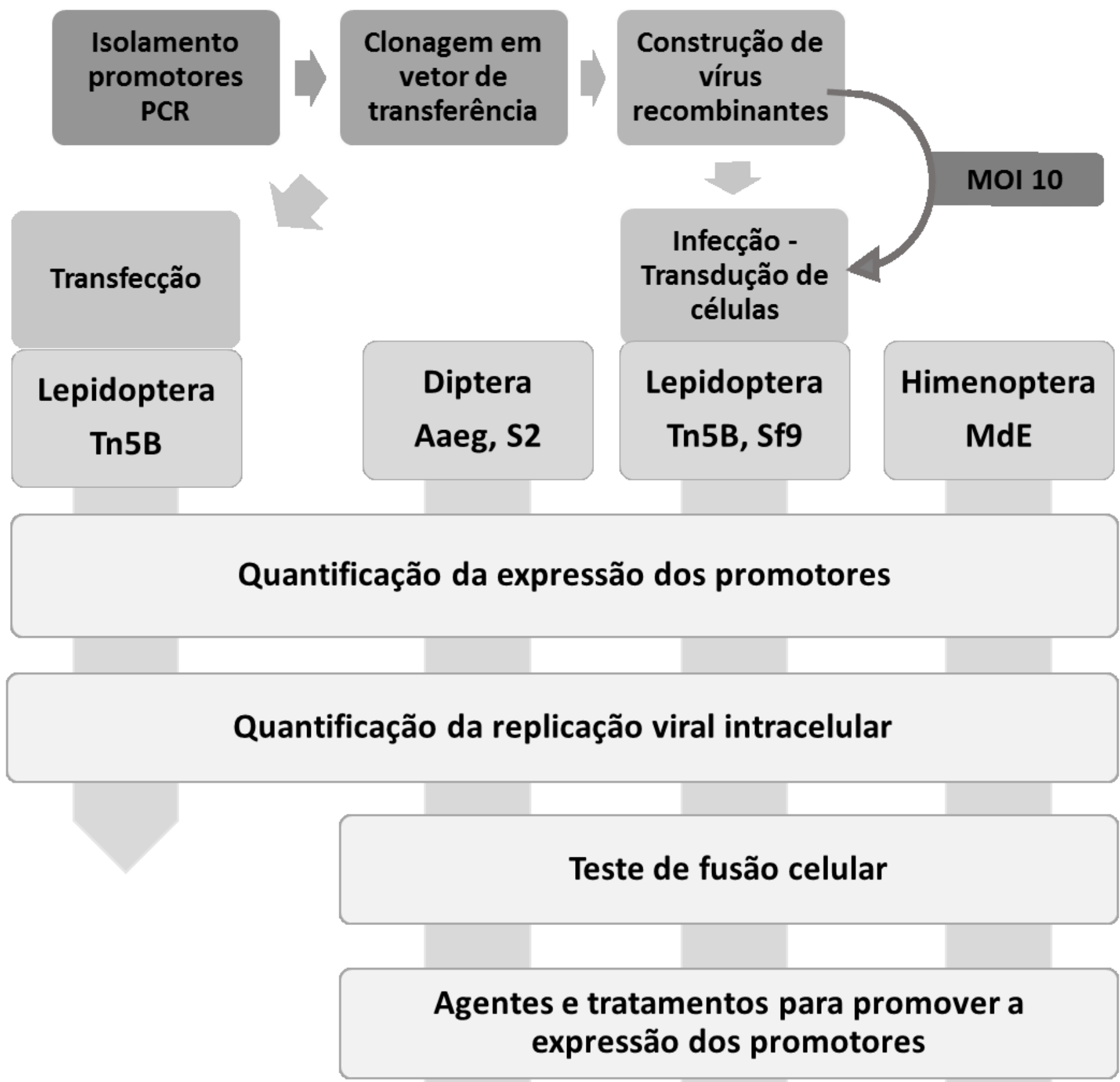

Fluxograma 2: Descrição geral dos procedimentos e materiais utilizados para estudar as infecções dos baculovírus recombinantes AcMNPV contendo promotores do vírus Microplitis demolitor Bracovírus regulando o gene repórter quimioluminescente fluc. 


\section{MATERIAL E MÉTODOS}

\subsection{Baculovírus recombinantes}

Neste trabalho, utilizamos os baculovírus $A g \mathrm{MNPV}$ recombinantes construídos anteriormente contendo promotores de genes do vírus $A g \mathrm{MNPV}$ : vAgIE1FLUC, vAgGP64FLUC, vAgLEF1FLUC, vAgVP39FLUC, vAgP6.9FLUC e vAgPOLHFLUC (Morgado, 2012). Todos possuem promotores virais controlando o gene fluc (Luciferase do vaga-lume Photinus pyralis) inseridos no locus do gene da proteína poliedrina (polh). Esses vírus foram construídos por recombinação homóloga em células de insetos (Figura 4) utilizando o plasmídeo de transferência p2100 que possui 2100 pares de base (pb) do locus da polh de $A g \mathrm{MNPV}$. Estes $A g \mathrm{MNPV}$ recombinantes possuem o gene e promotor polh íntegros, portanto são capazes de formar corpos de oclusão (oclusão positivos) (Cordeiro et al, 2008).

Também utilizamos o sistema BAC-to-BAC (Invitrogen) de construção de baculovírus AcMNPV recombinantes por transposição sítio específica em bactérias DH10BAC (Invitrogen).

\subsection{Linhagens celulares e cultivo}

As linhagens celulares derivadas de insetos utilizadas neste trabalho foram: UFLAG-286 derivada de embriões de Anticarsia gemmatalis crescidas em meio TC-100 (UFLAg, Sieburth \& Maruniak, 1988), BTI-Tn5B1-4 derivada de embriões (ovos) de Trichoplusia ni em meio TC-100 (Tn5B, Granados et al., 1994), Spodoptera frugiperda (Sf21, Vaughn et al., 1977), Sf9 derivada de ovário de pupas e crescida em meio TC-100 (que por sua vez é uma linhagem derivada de IPLB-SF21-AE, Vaughn et al., 1977), WuCce-1 derivada de embriões de Chrysodeixes chalcites (Chch, Xu et al, 2010), IPLBLd652Y derivada de ovários de pupas de Limantria dispar e crescida em meio Grace 
(Ld652Y, Goodwin et al, 1978), BM5 derivada de ovários de pupas de Bombyx mori crescidas em meio Grace (Bm5, Grace, 1967). As linhagens celulares derivadas de Drosophila melanogaster Schneider 2 (S2, Schneider, 1972) e Aedes aegypti Aaeg2 (Singh, 1967) foram cultivadas com o meio Sf900III (Gibco). A linhagem celular derivada de embriões de Microplitis demolitor MdE1 (sem referência, sem publicação, pertence ao laboratório do dr. Michael Strand, University of Georgia, Department of Entomology) foi cultivada com meio Sf900-II (Gibco). Todos os meios de cultura de células de inseto foram suplementados com $10 \%$ de soro fetal bovino (FBS, Gibco).

\subsection{Isolamento dos promotores virais por PCR e clonagem no vetor de transferência pFASTBACAccI}

Para construir os baculovírus recombinantes pelo método BAC-to-BAC contendo os promotores de $A g \mathrm{MNPV}$ (genbank: NC_008520, Oliveira et al, 2006) e $A c \mathrm{MNPV}$ (genbank: NC_001623, Ayres et al, 1994) regulando o gene fluc, foi necessário subclonar o gene e os promotores de interesse no plasmídeo de transferência por transposição em bactérias $\mathrm{pFASTBAC}{ }^{\mathrm{TM}} 1$. Para tanto, foi realizada uma primeira modificação no pFASTBAC $^{\mathrm{TM}} 1$, que foi digerido com a enzima de restrição AccI, seguindo as instruções do fabricante (Promega). Para remover o promotor da poliedrina, localizado próximo à um sítio de múltipla clonagem, a reação de digestão foi submetida à eletroforese em gel de agarose 1\% (Sambrook et al., 2001) e a banda correspondente ao plasmídeo digerido foi eluída utilizando kit de eluição GFX (GE Healthcare). O remanescente do plasmídeo sem o promotor da poliedrina foi religado utilizando T4 DNA ligase (Promega, 4 unidades Weiss) e transformado em bactérias DH10B (Invitrogen), que foram selecionadas utilizando Ampicilina e Gentamicina, resultando no plasmídeo pFASTAccI (Ardisson-Araújo, 2015). 
Em paralelo, o plasmídeo construído anteriormente p2100AgP69FLUC, contendo o promotor do gene $p 6.9$ de $A g \mathrm{MNPV}$ regulando o gene $f l u c$, foi digerido pelas enzimas XhoI e HindIII (Promega, 4 unidades Weiss de cada enzima por reação), o que removeu o inserto prAgP69FLUC (2191 pb). A digestão foi submetida à eletroforese de gel de agarose para eluição do fragmento de DNA de interesse utilizando kit de eluição GFX (GE Healthcare). Isto tornou possível a clonagem direcional deste inserto no plasmídeo pFAST AccI digerido e eluído utilizando o mesmo procedimento. A ligação do plasmídeo pFASTAccI e o inserto prAgP69FLUC resultou na construção do plasmídeo pFASTAgP69FLUC. Este é o plasmídeo base em que os demais promotores foram clonados pela remoção do promotor $A g \mathrm{P} 6.9$ e inclusão dos demais através da digestão utilizando as enzimas HindIII e XmaI.

Os promotores de $A g \mathrm{MNPV}$ (IE1, GP64, LEF1, VP39 e POLH) e os promotores equivalentes de AcMNPV (IE1, GP64, LEF1, VP39 e P6.9) foram amplificados por reação de cadeia da polimerase (PCR) a partir de 10 ng de DNA genômico de $\mathrm{AgMNPV}$ ou AcMNPV utilizando primers específicos (Tabela 1), Taq Polimerase (GoTaq, Promega, 1 unidade Weiss por reação). Os parâmetros do termociclador para a reação de PCR foram: Desnaturação a $96^{\circ} \mathrm{C}$ por 2 min seguido por 35 ciclos de desnaturação a $96^{\circ} \mathrm{C}$ por $40 \mathrm{~s}$, anelamento a $55^{\circ} \mathrm{C}$ por $30 \mathrm{~s}$, extensão a $72^{\circ} \mathrm{C}$ por $40 \mathrm{~s}$ e por fim extensão final a $72^{\circ} \mathrm{C}$ por $4 \mathrm{~min}$. As bandas de interesse foram isoladas por eletroforese em gel de agarose e eluição conforme descrito anteriormente. Estas foram clonadas pelo método TA cloning em pGEMT-Easy (Promega) por ligação utilizando T4 DNA ligase (Promega, 4 unidades Weiss). Os produtos das ligações foram, transformados em células E. coli DH10B, conforme recomendações do fabricante, utilizando Ampicilina como antibiótico de seleção plasmidial, resultando em plasmídeos pGEM contendo cada um dos promotores isolados. 
Para selecionar as regiões promotoras, levou-se em conta o conceito prévio de que existe uma tendência a serem compactos e se concentrarem em regiões intergênicas (mais apropriadamente inter-open reading frames, revisado em Rohrmann, 2013; Chen et al, 2013), sendo esta característica bem conservada entre todos NPVs. Foram tomadas como regras de escolha para o desenho dos primers de amplificação: Presença dos motivos de transcrição conhecidos; Englobar o máximo da região intergênica possível sem invadir a ORF upstream; Presença dos sítios de restrição utilizados na clonagem; Não exceder 500 pb do amplicon. Outra referência de consulta foram os dados de início de transcrição de cada mRNA apresentado no transcriptoma do AcMNPV (Chen et al, 2013). Os primers desenhados e utilizados estão apresentados na tabela 1 . 
Tabela 1: Lista dos primers utilizados no isolamento dos promotores virais. A tabela também contém o tamanho do amplicon isolado por cada par de primers, além do tamanho e sequência (5'-3') de cada primer.

\begin{tabular}{|c|c|c|c|c|c|}
\hline Nome do primer & Vírus & Promotor & $\begin{array}{c}\text { Tamanho } \\
\text { amplicon } \\
\text { (pb) }\end{array}$ & $\begin{array}{c}\text { Tamanho } \\
\text { primers (pb) }\end{array}$ & Sequência \\
\hline prAgIE1FWR & \multirow{12}{*}{ AgMNPV } & \multirow{2}{*}{ IE1 } & \multirow{2}{*}{468} & 28 & TAGCAAGCTTCGCAATCCGTTGACGTGT \\
\hline prAgIE1REV & & & & 28 & TAGCCCCGGG GAACGTCTATTTATACCC \\
\hline prAgGP64FWR & & \multirow{2}{*}{ GP64 } & \multirow{2}{*}{370} & 32 & TAGCAAGCTTGGATCCATTTGATGAAGGTCT \\
\hline prAgGP64REV & & & & 30 & TAGCCCCGGG GGATCTTTGTTATGTCTTGT \\
\hline prAgLEF1FWR & & \multirow{2}{*}{ LEF1 } & \multirow{2}{*}{258} & 27 & AGCAAGCTTGTTGCGGCTTGACCACGG \\
\hline prAgLEF1REV & & & & 30 & AGCCCCGGGTAGGGCGTCTATAAAATCGGG \\
\hline prAgVP39FWR & & \multirow{2}{*}{ VP39 } & \multirow{2}{*}{370} & 37 & AAGCAAGCTTTTCGCGCCACACAAGCGGCACCAACG \\
\hline prAgVP39REV & & & & 36 & TTACCCGGG TITGCTACAATGGACGACTTTGTGATT \\
\hline prAgP6.9FWR & & \multirow{2}{*}{ P6.9 } & \multirow{2}{*}{463} & 34 & ACTGAAGCTTTCGCCAGCCCTGTGATGCGTTACG \\
\hline prAgP6.9REV & & & & 34 & ATTACCCGGGAAGTGTTTTACAATGTAGCTTTAA \\
\hline prAgPOLHFWR & & \multirow{2}{*}{ POLH } & \multirow{2}{*}{397} & 31 & AAGCAAGCTTATTTGGAGTGTTTGTACGATT \\
\hline prAgPOLHREV & & & & 35 & ATTACCCGGGAGTTATAGCAAATITACTACAAAG \\
\hline prAclE1FWR & \multirow{12}{*}{ AcMNPV } & \multirow{2}{*}{ IE1 } & \multirow{2}{*}{390} & 30 & TAGCAAGCTTAACGGCGCAGTGTACTTGTT \\
\hline prAclE1REV & & & & 30 & TAGCCCCGGGAGTCACTTGGTTGTTCACGA \\
\hline prAcGP64FWR & & \multirow{2}{*}{ GP64 } & \multirow{2}{*}{261} & 30 & TAGCAAGCTTTGCTGTCGGGAGAGTACATG \\
\hline prAcGP64REV & & & & 31 & TAGCCCCGGGTGCTTGTGTGTTCCTTATTGA \\
\hline prAcLEF1FWR & & \multirow{2}{*}{ LEF1 } & \multirow{2}{*}{358} & 30 & TAGCAAGCTTTGTCGGCATTAATTCCGTG \\
\hline prAcLEF1REV & & & & 30 & TAGCCCCGGGGTTGCCCTTTGAACTTGACC \\
\hline prAcVP39FWR & & \multirow{2}{*}{ VP39 } & \multirow{2}{*}{320} & 29 & TAGCAAGCTTTTCTCTCCACACCAACGGC \\
\hline prAcVP39REV & & & & 30 & TAGCCCCGGGATTGTTGCCGTTATAAATAT \\
\hline prAcP69FWR & & \multirow{2}{*}{ P6.9 } & \multirow{2}{*}{427} & 29 & TAGCAAGCTTACAAACGCACCACTCTTGA \\
\hline prAcP69REV & & & & 30 & TAGCCCCGGGTGTGTAATTTATGTAGCTGT \\
\hline prAcPOLHFWR & & \multirow{2}{*}{ POLH } & \multirow{2}{*}{197} & 30 & TAGCAAGCTTCGAGCAGTTGTTTGTTGTTA \\
\hline prAcPOLHREV & & & & 30 & TAGCCCCGGG TITTATTACAAAACTGTTAC \\
\hline prMdVP39fwr & & \multirow{2}{*}{ VP39 } & 327 & 24 & AAGCTTCGCAAACTGTTACAACTA \\
\hline prMdVP39rev & & & 327 & 27 & CCCGGGTTATTATTTATTTGCAGTGCA \\
\hline prMdLEF5fwr & & IFF5 & 348 & 28 & AAGCTTTTATITTATTAACCTGTATGAG \\
\hline prMdLEF5rev & & LEFJ & 348 & 27 & CCCGGGTCACTCAATAAATTAAACCGT \\
\hline prMdLEF9fwr & & IFFO & $\triangle 46$ & 26 & AAGCTTCGAGTCGCACAACAACATTC \\
\hline prMdLEF99rev & & LEFy & 440 & 31 & CCCGGG ATTACAATTAATAACTTTACATACA \\
\hline prMd35a6fwr & & $35 \mathrm{AG}$ & 308 & 27 & AAGCTTAGCTCCGTCTGTTGATAGTGA \\
\hline prMd35a6rev & IVIdBV & उSAO & 308 & 28 & CCCGGGTCGCCATATTTAATTATTTGTT \\
\hline prMdORF64fwr & & HzNV-O6-4 & 359 & 25 & AAGCTTGGTCCCAAATGAGCCATAT \\
\hline prMdORF64rev & & & 359 & 26 & CCCGGGTGCGTGTITTCGTTGTCGA \\
\hline prMdORF92fwr & & HzNV-OQ-? & 313 & 28 & AAGCTTATAACTGTCATATTACCAGAAA \\
\hline prMdORF92rev & & HZINV-UY-L & 313 & 29 & CCCGGGTCGTAACAAACAATATCAATATT \\
\hline prMdPIF2fwr & & & & 27 & AAGCTTCATGATCATGATTGGCCAGCA \\
\hline prMdPIF2rev & & PIF2 & 291 & 26 & CCCGGGAGATATITATCGTTGCGTT \\
\hline
\end{tabular}

Os plasmídeos pGEM resultantes foram amplificados, isolados por midiprep (Sambrook et al, 2001) e sequenciados (Macrogen, Coréia do Sul), utilizando os primers universais M13 (M13fwr-21 5'-TGTAAAACGACGGCCAGT-3' e M13rev 5'CAGGAAACAGCTATGAC-3', $0.2 \mu \mathrm{M}$ de cada primer por reação). Após o sequenciamento e confirmação das sequências isoladas, os plasmídeos foram submetidos 
à digestão com as enzimas HindIII e XmaI. As bandas correspondentes aos promotores foram eluídas de gel de agarose como descrito anteriormente. De forma similar, o plasmídeo pFASTAgP69FLUC foi digerido e o fragmento correspondente ao vetor sem o promotor AgP6.9 foi eluído.

Reações de ligação de cada promotor ao plasmídeo sem o promotor prAgP69 (pFASTFLUC) digerido foram realizadas utilizando T4 DNA ligase (Promega) e as ligações foram transformadas em bactérias DH10B. A clonagem dos promotores foi confirmada por PCR utilizando o primer forward (FWR, $0.2 \mu \mathrm{M})$ de cada promotor e primer que anela no gene $f l u c$ (FLUCREV - 5'-GACATAGCTTACTGGGACGA-3`, 0.2 $\mu \mathrm{M}$ ), de forma a amplificar uma banda de aproximadamente $1600 \mathrm{pb}$ (cujo tamanho exato depende do tamanho do promotor em cada caso, figura 6), que foram confirmadas por visualização em gel de agarose. Os plasmídeos confirmados por PCR foram amplificados, purificados por midiprep (Sambrook, 2001) e sequenciados (Macrogen, Coréia do Sul; IDT, EUA) utilizando o primer pFseq (5 -GATCCTCTAGTACTT-3`), cujo anelamento no plasmídeo pFAST a montante das regiões promotoras permitiu a confirmação da correta sequência e orientação de cada elemento. A figura 6 descreve as clonagens dos promotores realizadas no vetor pFASTAccI e a topologia dos elementos gênicos.

Os promotores derivados da vespa Microplitis demolitor foram obtidos por PCR a partir do DNA genômico total extraído do abdômen de 10 vespas fêmeas adultas que foram macerados e tratados com o kit de extração DNeasy Blood \& Tissue Kit (Qiagen), seguindo as instruções do fabricante. As reações de PCR foram realizadas utilizando iProof High-Fidelity PCR Kit (Bio-Rad), 10 ng de DNA genômico e $0.2 \mu \mathrm{M}$ de cada primer específico, utilizados em pares, para isolar cada promotor (Tabela 1) e posteriormente, purificadas pelo kit utilizando o kit GeneJET Gel Extraction Kit (Thermo Fisher). $2 \mu \mathrm{g}$ de DNA de cada reação de PCR foram submetidos à digestão enzimática 
pelas enzimas HindIII e XmaI (NEB, 5 unidades Weiss de cada por reação) e em seguida os materiais foram eluídos após eletroforese em gel de agarose utilizando o kit GeneJET Gel Extraction Kit (Thermo Fisher). Os fragmentos digeridos foram submetidos à reações de ligação com o plasmídeo de transferência pFASTAccI contendo o gene fluc conforme apresentado anteriormente (Figura 6). Os plasmídeos resultantes foram sequenciados utilizando o primer pFseq conforme descrito anteriormente.

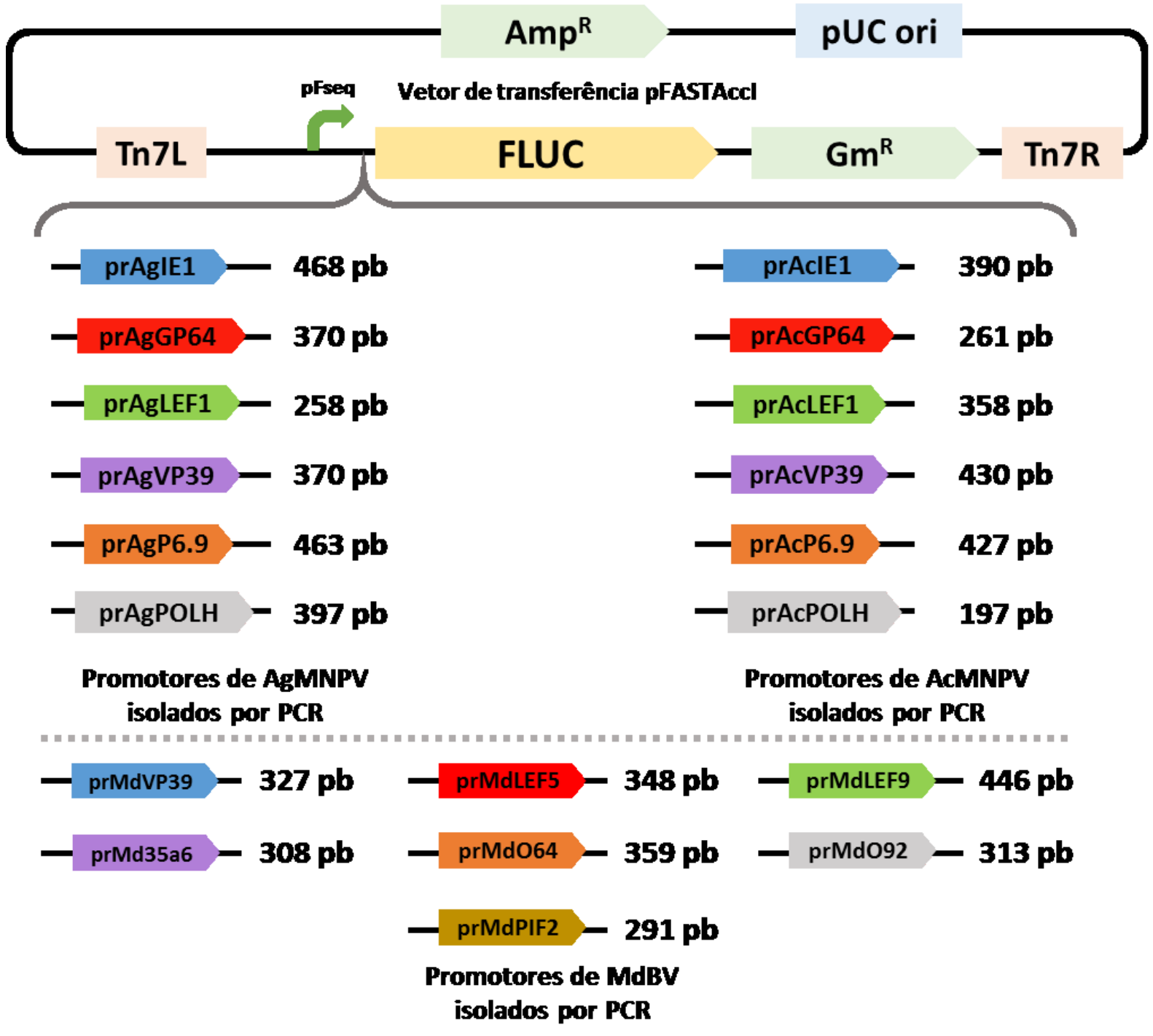

Figura 6: Diagrama e mapa vetor representando a estratégia de clonagem no plasmídeo de transferência por transposição em E. coli DH10BAC, no topo o plasmídeo modificado pFASTBACAccl. Abaixo os promotores isolados por PCR e digeridos com as enzimas HindIII (5') e Xmal (3'). No vetor de transferência está indicada a posição de anelamento do primer pFseq upstream ao gene Luciferase de vagalume (FLUC), os elementos alvo de transposição $\mathrm{Tn} 7$ (em rosa) flanqueiam o gene FLUC e o gene de resistência a Gentamicina $\left(\mathrm{Gm}^{\mathrm{r}}\right)$. 0 vetor também contém a origem de replicação derivada do plasmídeo pUC (pUC ori) e o gene de resistência à Ampicilina (Ampr). 


\subsection{Construção de baculovírus $A c M N P V$ recombinantes através do método BAC-to-BAC}

O sistema BAC-to-BAC ${ }^{\mathrm{TM}}$ (Invitrogen) de geração de baculovírus recombinante é baseado na utilização de um baculovírus $A c \mathrm{MNPV}$ recombinante que contém a origem de replicação mini-F e gene de resistência à Canamicina e o gene $L a c Z$ modificado com uma sequência alvo de transposição do transposon Tn7. O DNA viral, na forma de um plasmídeo (também denominado de bacmídeo), é mantido em E. coli DH10BAC ${ }^{\mathrm{TM}}$ (Invitrogen), que também contém um plasmídeo helper selecionado por Tetraciclina e contém os elementos gênicos do transposon Tn7. Desta forma, ao transformar células DH10BAC ${ }^{\mathrm{TM}}$ com os plasmídeos de transferência pFAST (que contém alvos de excisão Tn7 flanqueando os promotores, genes de interesse e gene de resistência à Gentamicina), ocorre transposição de elementos deste ao genoma viral interrompendo o gene LacZ. Utilizando reações de PCR com os primers universais M13, que anelam no gene LacZ, é possível confirmar a inserção do elemento transposto no bacmídeo. Os ácidos nucleicos dos bacmídeos confirmados são então transfectados em células de inseto permissivas a $A c \mathrm{MNPV}$, resultando na formação de baculovírus infectivos.

Os plasmídeos pFASTpromotorFLUC foram transformados individualmente em células DH10BAC ${ }^{\mathrm{TM}}$ quimiocompetentes que foram plaqueadas em placas LB contendo $50 \mu \mathrm{g} / \mathrm{mL}$ de Canamicina, $7 \mu \mathrm{g} / \mathrm{mL}$ de Gentamicina, $10 \mu \mathrm{g} / \mathrm{mL}$ de Tetracycline, 100 $\mu \mathrm{g} / \mathrm{mL}$ de X-gal e $40 \mu \mathrm{g} / \mathrm{mL}$ de IPTG. Após $24 \mathrm{~h}$ de incubação em estufa a $37^{\circ} \mathrm{C}$, colônias brancas de cada placa foram submetidas a PCR de colônia utilizando os primers universais M13. Uma colônia azul de cada placa foi utilizada como controle negativo de transposição. Reações de PCR utilizando os primers forward de cada promotor e o primer FLUCREV também também foram realizadas como confirmação da presença dos elementos promotores e gene fluc, seguindo os parâmetros citados anteriormente. As reações de PCR foram submetidas a eletroforese em gel de agarose e as colônias com 
amplificação positiva (aproximadamente 4000 pb, em comparação aos controles negativos que amplificam uma banda de $300 \mathrm{pb}$ no caso dos primers M13) foram coletadas para crescimento por $16 \mathrm{~h}$ (overnight) em $10 \mathrm{ml}$ de meio LB contendo os antibióticos citados anteriormente.

O DNA viral de cada recombinante foi purificado utilizando kits de miniprep Wizard® Plus SV Minipreps DNA Purification System (Promega) ou GeneJET Plasmid Miniprep Kit (Thermo Fisher Scientific), seguindo recomendações dos fabricantes. Os DNAs purificados foram quantificados por medição de absorbância em Nanodrop 2000 (Thermo Fisher Scientific) ou Nanovue (GE Healthcare).

Os DNAs quantificados (aproximadamente $500 \mathrm{ng}$ de cada) foram transfectados em 1 x $10^{5}$ células Tn5B em placas estéreis de 6 poços utilizando FuGENE® 6 Transfection Reagent (Promega) como reagente de transfecção, seguindo recomendações do fabricante. As células transfectadas foram incubadas a $27^{\circ} \mathrm{C}$ por 6 dias e após este período, o meio de cultura e células foram ressuspendidos e separados por centrifugação (5000 x g / $10 \mathrm{~min})$. O sobrenadante foi mantido a $4^{\circ} \mathrm{C}$ enquanto que as células sedimentadas foram testadas para presença de quimioluminescência seguindo o protocolo de detecção de luciferase por lise celular de células infectadas (seção 3.6.1), utilizando o espectrofotômetro-luminômetro Synergy (Biotek) no modo luminometria com $5 \mathrm{~s}$ de integração e sensibilidade 250 (máxima).

\subsection{Amplificação e titulação dos inóculos virais recombinantes}

Os bacmídeos construídos foram amplificados infectando 5 × $10^{6}$ células $\mathrm{Sf9}$, que é a linhagem recomendada para amplificação do vírus no sistema BAC-to-BAC, em frascos de cultivo $\left(75 \mathrm{~cm}^{2}\right)$ contendo $15 \mathrm{ml}$ de meio TC-100 com $200 \mu \mathrm{l}$ do sobrenadante das transfecções. As células foram incubadas em estufa a $27^{\circ} \mathrm{C}$ por 5 dias e após este 
período, o meio de cultura foi coletado, clarificado por centrifugação em tubos cônicos $(5000 \mathrm{x} \mathrm{g} / 10 \mathrm{~min})$ e mantido a $4^{\circ} \mathrm{C}$.

Os baculovírus recombinantes de $A g \mathrm{MNPV}$, contendo promotores de $A g \mathrm{MNPV}$ regulando o gene fluc, foram amplificados pela infecção de 5 x $10^{6}$ células da linhagem celular UFLAg incubadas por 5 dias em estufa a $27^{\circ} \mathrm{C}$. Após a incubação, o sobrenadante foi separado das células e coletado após centrifugação em tubos cônicos a (5000 x g / 10 min). Os estoques virais foram mantidos a $4^{\circ} \mathrm{C}$.

A titulação destes estoques foi realizada pela técnica end-point dilution (TCID 50 , O’Reilly et al., 1992; que é baseada na técnica desenvolvida por Reed \& Muench, 1938), em que diluições seriadas do estoque viral são usadas para infectar poços de uma placa de 96 poços contendo células UFLAg (para os recombinante $A g M N P V$ ) e Tn5B (para os recombinantes $A c \mathrm{MNPV})$. Pela contagem da presença de infecção ou não dos poços de cada diluição é possível calcular o número de unidades formadoras de placas (PFU, plaque forming units), o que permite a utilização dos inóculos virais na forma de multiplicidade de infecção por célula (MOI, multiplicity of infection). Para realizar os cálculos utilizamos planilha em Excel derivada de O’ Reilly et al. (1992).

\subsection{Ensaios de deteç̧ão da atividade de luciferase em células de inseto}

A enzima quimioluminescente firefly luciferase é uma proteína derivada do vagalume Photinus pyralis, cujo gene foi isolado e é comercializado na forma de plasmídeo com diversas modificações na sequência do gene, para retirar motivos de direcionamento aos lisossomos e aumento na eficiência da reação enzimática (Allard \& Kopish, 2008). A atividade quimioluminescente é resultado da associação entre o monômero protéico Luciferase, solúvel no citoplasma de célula eucariótica, uma molécula de ATP, $\mathrm{O}_{2}$ e o reagente D-luciferina. ATP e $\mathrm{O}_{2}$ são componentes intrínsecos das células enquanto que a 
enzima luciferase e D-luciferina são moléculas raras entre os organismos vivos, sendo encontradas em alguns insetos da ordem Coleoptera, como o vaga-lume Photinus pyralis.

Os reagentes de lise celular e a D-luciferina fazem parte do kit luciferase Assay Reagent (Promega), que contém o tampão de lise Cell Culture Lysis Reagent (CCLR) e D-luciferina ressuspendida no tampão fornecido pelo fabricante. O luminômetro utilizado foi o GloMax® 96 Microplate Luminometer (Promega), utilizando um tempo de integração de $5 \mathrm{~s}$ por poço em placas de 96 poços escuras de fundo opaco. Os dados surgem como Unidades de Luminescência Relativa (RLU, Relative Light Units).

\subsubsection{Ensaios de medição por lise}

O ensaio típico da atividade da enzima luciferase envolve a expressão do gene repórter fluc a partir do vetor de expressão em células. Em diferentes tempos após o tratamento inicial, as células são lisadas, liberando o conteúdo citoplasmático, o extrato celular é misturado ao reagente D-luciferina e a luminescência derivada deste extrato é medido em luminômetro. Quanto mais luciferase for produzida pelas células, maior a luminescência medida a partir do extrato.

Para preparar uma placa de 12 poços, primeiro foram adicionados a um tubo cônico de $50 \mathrm{~mL}$. Em seguida, 2,5 x $10^{6}$ células UFLAg ressuspendidas em $12 \mathrm{~mL}$ de meio TC-100 contendo 10\% FBS e inóculo viral contendo MOI 10. Desta mistura então, semeamos $1 \mathrm{~mL}$ em cada poço da placa de 12 poços (compondo então 208 mil células por poço). Este é o tempo 0 horas após a infecção (h p.i.). Após 1, 3, 6, 12, 24, 48 e $72 \mathrm{~h}$ p.i., o meio de cultura foi removido e as células foram lavadas no poço e ressuspendidas utilizando PBS, centrifugadas a 3000 x g / 5 min. Os sedimentos de células foram ressuspendidos em $100 \mu 1$ de tampão de lise CCLR, incubados por 5 min à temperatura ambiente e centrifugados a 3000 x g / 5 min para coletar debris celulares não lisados. Os 
$100 \mu 1$ de lisado celular foram transferidos à placa de 96 poços e $1 \mu 1$ do substrato da reação de quimioluminescência foi adicionado a cada poço. $2 \mu \mathrm{l}$ de cada lisado foram separados para quantificação total de proteínas. A luminescência derivada de cada poço foi medida no luminômetro Glomax 96.

A quantificação total de proteínas foi realizada utilizando o método Bradford (Sambrook, 2001). $98 \mu 1$ de reagente Bradford foi alocado a poços de uma placa transparente de 96 poços, $2 \mu 1$ de albumina bovina (BSA, bovine serum albumin) em concentrações $10 \mu \mathrm{g}, 1 \mu \mathrm{g}, 100 \mathrm{ng}, 10 \mathrm{ng}, 1 \mathrm{ng}$ e $0.1 \mathrm{ng}$ (por $\mu \mathrm{l}$ ) foram adicionados ao reagente Bradford, em triplicatas, para formar a curva padrão. Dois $\mu 1$ dos lisados obtidos foram transferidos a poços contendo reagente Bradford. Após incubação de 5 min em temperatura ambiente, a absorbância de cada mistura foi medida em espectrofotômetro Spectramax M5 (Molecular Devices), utilizando detecção a 595 nm. As absorbâncias dos poços com concentração conhecida geraram uma curva padrão da qual foram derivadas as concentrações absolutas dos lisados celulares. Estas concentrações foram usadas para normalizar os valores de luminescência obtidos.

A partir das triplicatas de medição de luminescência foram obtidos a média e o desvio padrão em relação à média. Todas as análises foram realizadas utilizando o software Graphpad Prism (para análises estatísticas como elaboração da curva padrão do método Bradford de quantificação de proteínas, normalização de dados e comparação de médias por teste $\mathrm{t}$ ).

\subsubsection{Ensaios de detecção da atividade de luciferase em células de inseto (não derivadas de Lepidoptera) transduzidas com baculovírus recombinantes contendo promotores virais}

Diferente do processo de infecção celular, onde um sobrenadante contendo vírus maduro é adicionado à células suscetíveis à infecção, a transdução é um processo onde o 
vírus é adicionado à uma linhagem celular que não é suscetível a infecção celular mas a célula ainda pode receber a partícula viral e efetivamente transcrever genes a partir deste ácido nucléico. Este procedimento é comumente realizado quando aplica-se baculovírus recombinantes em células não-permissivas, como as derivadas de mamíferos, em uma metodologia para realizar entrega e expressão de genes de interesse de forma não lítica. Neste caso, a transdução foi realizada em linhagens celulares de inseto não-permissivas ao AcMNPV, que não são da ordem Lepidoptera, nominalmente na linhagem S2 derivada da mosca Drosophila melanogaster, linhagem Aaeg2 derivada do mosquito Aedes aegypti e a linhagem MdE derivada da vespa Microplitis demolitor.

Este experimento tem como objetivo avaliar a atividade dos promotores derivados de $M d \mathrm{BV}$ nestas linhagens com um background filogenético mais próximo ao da vespa M. demolitor, em comparação às linhagens derivadas de Lepidoptera (Sf9, Tn5B, etc). Neste experimento, também foram utilizados baculovírus AcMNPV recombinantes contendo os promotores pr $A c \mathrm{IE} 1, \operatorname{pr} A c \mathrm{P} 69$ e prAcPOLH em paralelo aos promotores de MdBV para servir de comparação.

Para realizar este experimento, $4 \times 10^{4}$ células de cada linhagem foram semeadas por poço em placas de 96 poços. Após observar por microscopia de luz que as células aderiram ao fundo do poço, os vírus recombinantes foram adicionados em MOI 10 e as células com vírus foram incubadas por $1 \mathrm{~h}$ para adsorção do vírus na membrana celular. Após este período o meio de cultura contendo vírus não adsorvidos foi removido e descartado. Novo meio de cultura foi reposto $(200 \mu \mathrm{l})$ e as células foram incubadas por $48 \mathrm{~h}$ a $27^{\circ} \mathrm{C}$. As infecções foram realizadas em triplicatas para cada vírus recombinante.

No momento de coleta, o sobrenadante foi removido e descartado e $100 \mu \mathrm{l}$ do tampão de lise CCLR (do kit Luciferase Assay System, Promega) foi adicionado sobre as células e incubado por $5 \mathrm{~min}$. O lisado celular foi coletado e transferido à tubos de 
microcentrífuga e foram centrifugados por 3000 x g / 5 min, para separar fragmentos celulares e células não lisadas, o sobrenadante então foi transferido para uma placa branca opaca e $10 \mu \mathrm{l}$ de Luciferina (do kit Luciferase Assay System, Promega) foi adicionado por poço. Não foi realizada normalização utilizando o total de proteínas neste ensaio. A leitura da luminescência da placa foi realizada no equipamento Synergy 2 (BioTek), com máxima sensibilidade (250) e $5 \mathrm{~s}$ de integração.

\subsubsection{Ensaios de detecção da atividade de luciferase em células de inseto transfectadas com plasmídeos contendo promotores virais}

Para avaliar a atividade dos promotores de $M d \mathrm{BV}$ em células Tn5B, permissiva ao baculovírus AcMNPV, sem o "auxílio" de elementos virais contidos nos baculovírus (como os transativadores iel e pe38) e assim avaliar a afinidade dos elementos transcricionais da célula hospedeira pelos promotores em questão, foram realizadas transfecções dos plasmídeos pFASTFLUC contendo os promotores virais de interesse.

Neste experimento, $5 \times 10^{5}$ células Tn5B foram semeadas por poço em placas de 12 poços. Após adsorção das células (aproximadamente $1 \mathrm{~h}$ ), a transfecção dos plasmídeos foi realizada. Para cada poço foram preparados complexos de transfecção utilizando o agente de transfecção FuGene HD (Promega). O preparo dos complexos foi realizado misturando $200 \mu \mathrm{l}$ de meio de cultura sem soro, $2 \mu \mathrm{g}$ de DNA ao volume e por fim adicionando $16 \mu 1$ do reagente FuGene. A reação foi homogeneizada, incubada por 10 min em temperatura ambiente e depois adicionada gota a gota sobre os poços. A placa foi incubada por $48 \mathrm{~h}$ em estufa com temperatura $25^{\circ} \mathrm{C}$. As tranfecções foram realizadas em triplicatas para cada plasmídeo pFASTFLUC contendo os promotores de $M d \mathrm{BV}$ e os promotores pr $A c \mathrm{IE} 1, \operatorname{pr} A c \mathrm{GP} 64$, pr $A c \mathrm{P} 69$ e pr $A c \mathrm{POLH}$ derivados de $A c \mathrm{MNPV}$.

No momento de coleta, o sobrenadante foi removido, descartado e $200 \mu \mathrm{l}$ do tampão de lise CCLR foi adicionado sobre as células e incubado por 5 min a temperatura 
ambiente. O lisado celular foi coletado e transferido à tubos de microcentrífuga que foram centrifugados por $3000 \times \mathrm{g} / 5 \mathrm{~min}$, para separar fragmentos celulares e células não lisadas. O sobrenadante então foi transferido para uma placa branca opaca e $20 \mu 1$ de Luciferina (Luciferase Assay System, Promega) foi adicionado por poço. Não foi realizada normalização utilizando o total de proteínas neste ensaio. A leitura da luminescência da placa foi realizada no equipamento Synergy 2 (BioTek), com máxima sensibilidade (250) e $5 \mathrm{~s}$ de integração. As análises estatísticas foram realizadas em Graphpad Prism (utilizado para plotar gráficos e realizar análises de comparação por Teste t quando comparando médias entre si).

\subsubsection{Ensaios de medição contínua}

Esta técnica é uma forma distinta da medição de quimioluminescência por lise pois as células são plaqueadas, infectadas e a luminescência é obtida em tempo real, sem interrupção do processo de infecção na placa, de forma a obter a partir da mesma população de células a luminescência relativa ao momento da infecção viral. O princípio desta técnica reside em suplementar cada meio de cultura com D-luciferina (Luciferin disodium salt, Thermo Fisher) na concentração de $20 \mathrm{mM}$, e esterilizar os meios em filtros $0,22 \mu \mathrm{m}$.

Um dia antes do ensaio, o meio de cultura das células em crescimento em garrafas $25 \mathrm{~cm}^{2}$ foi cautelosamente removido e o meio modificado contendo luciferina, foi adicionado. Isto permitiu que as células absorvam a luciferina contida no meio antes da infecção. Nos momentos prévios a infecção, as células foram contadas por hemacitômetro

e diluídas com meio de cultivo suplementado com D-luciferina para atingir a concentração de 1 × $10^{6}$ células / ml. Estas foram semeadas em placa de 96 poços escura, opaca e estéril. A placa foi incubada por $2 \mathrm{~h}$ para permitir adesão das células ao fundo do 
poço. Logo em seguida, o inóculo viral foi adicionado para atingir a MOI 10 e a placa foi incubada por mais uma h em temperatura ambiente $\left(25^{\circ} \mathrm{C}\right)$. Após este período de adsorção do vírus nas células, o meio de cultura foi removido e novo meio suplementado com Dluciferina foi adicionado, iniciando o tempo de contagem da infecção.

A placa foi incubada no interior do luminômetro Glomax 96 em temperatura ambiente $\left(25^{\circ} \mathrm{C}\right)$, e a luminescência resultante por poço foi medida, utilizando como parâmetros $5 \mathrm{~s}$ de tempo de integração por poço a cada $999 \mathrm{~s}$ (16 min) ou em intervalos variáveis. Esta configuração de detecção (em placa escura e com o tempo de integração determinado) no Glomax 96, garantiu um baixo sinal basal de luminescência, de tal forma que sinais negativos de luminescência (células não infectadas ou células infectadas com vírus sem o gene FLUC) sempre apresentaram RLU abaixo de 20. Desta forma foi definido que o nível mínimo de luminescência para ser considerado um sinal válido nas análises é 20 RLU. Cada combinação de linhagem celular e vírus usados na infecção foram feitas em triplicatas. Os dados obtidos são usados para plotar gráficos XY (RLU x tempo), usando a média e desvio padrão em relação às triplicatas. É importante notar que este desenho experimental permitiu obtermos a média e desvio padrão dos valores RLU e dos valores de tempo para os parâmetros derivados das curvas, como tempo de primeira detecção (primeiro valor acima do nível background de 20 RLU) e tempo para atingir o pico de expressão (valor máximo de RLU obtido). Todas análises foram realizadas em Microsoft Office Excel (utilizado para organizar dados e plotar gráficos) e Graphpad Prism (utilizado para plotar gráficos e realizar análises de comparação: ANOVA two-way quando comparando séries temporais e Teste t quando comparando médias entre si).

\subsubsection{Efeito multiplicidade de infecção (MOI) sobre a expressão dos promotores de $\boldsymbol{A g M N P V}$}


Neste experimento, seguindo o desenho experimental definido anteriormente, células UFLAg, Tn5B e Sf9 foram utilizadas na concentração 1 x 10 $0^{6}$ células / ml (100 $\mu 1$ / poço $=1 \times 10^{5}$ células / poço). Os baculovírus recombinantes $A g M N P V$ utilizados neste ensaio foram vAgGP64FLUC, vAgVP39FLUC, vAgP69FLUC e vAgPOLHFLUC. Diferentes concentrações dos vírus foram utilizados para testar o efeito de MOI sobre a expressão destes promotores durante a infecção celular (ex.: considerando a concentração do inóculo $5 \times 10^{7} \mathrm{PFU} / \mathrm{ml}=2 \mu \mathrm{l} /$ poço resulta em MOI 1, $20 \mu \mathrm{l} /$ poço resulta em MOI 10, $200 \mu 1$ / poço resulta em MOI 100). As multiplicidades de infecção utilizadas foram $100,50,10,1,0.1,0.01,0.001$. Alíquotas dos inóculos foram diluídas com meio de cultura para atingir as multiplicidades abaixo de 1. As placas foram medidas no luminômetro Glomax 96 usando 5 s de tempo de integração por poço a cada 999 s (16 min) ou em intervalos variáveis.

\subsubsection{Efeito número de células sobre a expressão dos promotores de $\operatorname{AgMNPV}$}

Neste experimento células Tn5B foram utilizadas em diferentes concentrações de plaqueamento antes da infecção inicial. Antes do plaqueamento foi realizada a quantificação do número absoluto de células por hemacitômetro e em sequida as células foram diluídas em diferentes volumes de meio de cultura antes do plaqueamento para atingir concentrações desejadas de 1 x $10^{6}$ (100\% de confluência), 7.5 x $10^{5}$ (75\% de confluência), $5 \times 10^{5}$ (50\% de confluência), $2 \times 10^{5}$ células / $\mathrm{ml}$ (10\% de confluência). Quando as células aderidas estão em 100\% de confluência estas cobrem a superfície da placa restando pouco espaço e há maior contato entre estas células.

Os baculovírus AgMNPV utilizados neste ensaio foram vAgIE1FLUC, vAgVP39FLUC, vAgP69FLUC e vAgPOLHFLUC. MOI 10 foi utilizada em todas as concentrações de números de células. As placas foram medidas no luminômetro Glomax 
96 usando 5 s de tempo de integração por poço a cada 999 s (16 min) ou em intervalos variáveis.

\subsubsection{Perfil de expressão dos promotores de $A g$ MNPV em células permissivas e não-permissivas}

Neste experimento uma placa de 96 poços foi semeada com células UFLAg, Tn5B, Sf9, Ld652Y, Bm5 e Chch na concentração 1 x 10 células / ml $(150 \mu 1 /$ poço = $1.5 \times 10^{5}$ células). Os baculovírus $A g \mathrm{MNPV}$ recombinantes vAgIE1FLUC, vAgGP64FLUC, vAgLEF1FLUC, vAgVP39FLUC, vAgP69FLUC e vAgPOLHFLUC foram utilizados como inóculos para atingir $10 \mathrm{MOI}$.

As linhagens Ld652Y e Bm5 foram cultivadas com meio Grace suplementado com $10 \%$ de FBS e durante o experimento com este mesmo meio suplementado com 10 mM de D-luciferina. As placas foram medidas no luminômetro Glomax 96 usando $5 \mathrm{~s}$ de tempo de integração por poço a cada 999 s (16 min) ou em intervalos variáveis.

\subsubsection{Perfil de expressão dos promotores de $A g M N P V$ em células de inseto} tratadas com o inibidor de replicação Afidicolina

Este experimento seguiu o mesmo procedimento realizado no experimento anterior (seção 3.6.7), utilizando as células UFLAg, Tn5B, Sf9 e Ld652Y com os meios de cultura suplementados com $10 \mathrm{mM}$ de D-luciferina e $10 \mu \mathrm{M}$ do inibidor de replicação de DNA Afidicolina (Thermo Fisher).

1.6.9. Perfil de expressão dos promotores de $A c \mathrm{MNPV}, \operatorname{AgMNPV}$ e $M d \mathrm{BV}$ durante a infecção de células de inseto com os recombinantes $A c$ MNPV (bacmídeos) 
Os baculovírus recombinantes contendo os promotores de genes nãoencapsidados de $M d \mathrm{BV}$ foram utilizados para infectar as linhagens Tn5B e Sf9. Os baculovírus recombinantes contendo os promotores baculovirais de $A g \mathrm{MNPV}$ e AcMNPV foram utilizados para infectar em MOI 10 as linhagens UFLAg, Tn5B, Sf9, Ld652Y, Bm5 e Chch. Todos experimentos seguiram o mesmo procedimento da seção 3.6.2.3, com os meios de cultura suplementados com $10 \mathrm{mM}$ de D-luciferina.

\subsection{Quantificação do DNA viral dentro de células de inseto infectadas in vitro utilizando PCR em tempo real}

Para quantificar o DNA baculoviral durante a infecção de células de inseto foi utilizada a técnica de PCR em tempo real (qPCR) utilizando como sondas pares de primers para os genes fluc ou o gene iel. Os DNAs molde das reações foram obtidos a partir de extrações de DNA total das células infectadas (qPCR absoluta) quantificados e normalizados em termos de concentração de DNA total antes da reação. A detecção da amplificação foi realizada por reações de PCR contendo a o agente fluorescente intercalante de DNA SYBR green. As curvas de fluorescência foram convertidas em valores de CT (Cycle Threshold) que foram comparados à uma curva padrão realizada com concentrações conhecidas contendo o DNA alvo em ng / $\mu 1$, que são convertidos em número de cópias por 10 ng de DNA total por reação utilizando a equação: número de cópias $/ \mu \mathrm{l}=\left(\mathrm{X} \mathrm{g} / \mu 1 \mathrm{DNA} /\right.$ tamanho do plasmídeo em pb x 650) $* 6,022 \times 10^{23}$.

A quantificação do DNA viral durante as infecções com os baculovírus recombinantes derivados de $A g \mathrm{MNPV}$ foi realizada pelo plaqueamento de 2 × $10^{5}$ células por poço de uma placa de 96 poços. Após 2 h de adesão das células no fundo do poço, o vírus foi aplicado no poço em MOI 10 e a placa incubada por $1 \mathrm{~h}$ em temperatura ambiente, para permitir a adsorção do vírus nas membranas celulares. Após a incubação 
inicial o meio de cultura contendo excesso de vírus não adsorvido foi removido e $150 \mathrm{ul}$ de meio foi reposto. Após este momento iniciou-se a contagem do tempo de infecção viral. No momento de coleta $(1,3,6,9,12,24$ e 48 h p.i.), o sobrenadante de três poços (triplicatas) foram coletados e preservados para detecção dos vírus extracelulares (seção seguinte), $200 \mu \mathrm{l}$ de $\mathrm{PBS} \mathrm{pH} 7$ foi adicionado a cada poço e as células foram ressuspendidas por pipetagem e coletadas em um tubo de centrífuga. As células foram concentradas por centrifugação (1000 x $g$ por $10 \mathrm{~min})$ e o sobrenadante foi removido.

Para extrair o DNA total celular um método de extração que não utiliza solventes orgânicos foi utilizado. Este método lisa as células utilizando detergente e proteinase $\mathrm{K}$ em alta temperatura e precipita os ácidos nucléicos utilizando alta concentração de $\mathrm{NaCl}$ e álcool etílico. O pellet de células foi ressuspendido em $100 \mu 1$ de tampão TNES (10 mM Tris-Cl pH 7.5, $400 \mathrm{mM} \mathrm{NaCl}, 100 \mathrm{mM}$ EDTA e $0.6 \%$ SDS) e $5 \mu l$ de Proteinase $\mathrm{K}$ (10 $\mathrm{mg} / \mathrm{ml}$ ), em seguida foram incubados em banho a $55{ }^{\circ} \mathrm{C}$ por $4 \mathrm{~h}$. Após a incubação, $30 \mu \mathrm{l}$ de $\mathrm{NaCl} 5 \mathrm{M}$ foi adicionado e a solução foi misturada cautelosamente para evitar quebra do DNA de alta massa molecular. Isto induziu a precipitação de proteínas que foram concentradas por centrifugação $\left(12000 \times \mathrm{g}\right.$ por $15 \mathrm{~min}$ a $\left.4{ }^{\circ} \mathrm{C}\right)$. O sobrenadante foi coletado e $130 \mu \mathrm{l}$ de álcool etílico absoluto foi adicionado, a solução foi homogeneizada e incubada a $-4^{\circ} \mathrm{C}$ durante $16 \mathrm{~h}$. Para precipitar o DNA total, uma centrifugação foi realizada a 12000 x $g$ por 15 min, o sobrenadante então foi descartado e o pellet de DNA lavado com $300 \mu 1$ de álcool etílico absoluto e centrifugados novamente. Depois disto, o pellet de DNA foi resusspendido em $30 \mu$ de TE e quantificado utilizando espectrofotometria pelo equipamento Nanovue (GE Healthcare).

As reações de PCR foram realizadas utilizando o kit SsoFast EvaGreen Supermix (BioRad), seguindo recomendações do fabricante em reações de $10 \mu 1$ contendo $0.5 \mathrm{nM}$ de cada primer e $10 \mathrm{ng}$ de DNA total. O equipamento de detecção utilizado foi o 
Rotorgene Q (Qiagen) utilizando o rotor de 72 tubos. Os primers utilizados como sondas de detecção da infecção dos $A g M N P V s$ contendo o gene $f l u c$ foram FLUCqPCRFWR e FLUCqPCRREV (Figura 7 A). Para detectar as transduções de $A c$ MNPVs recombinantes em células de inseto não-lepidoptera foram utilizados os primers AcIE1qPCRFWR e AcIE1qPCRREV (Figura 7 B).

Para realizar a curva padrão para o par de primer tendo como alvo o gene fluc (Figura 7), uma diluição seriada, em água livre de RNAse, de concentrações conhecidas do plasmídeo pFAcP69FLUC (6705 pb, 1 ng de DNA = 136035975 cópias por ng) foram realizadas (10 ng a $1 \mathrm{fg}$ ) e aplicadas em quadruplicatas de reações de qPCR por cada concentração. O threshold de determinação do valor CT a partir das curvas de fluorescência foi de 0.01889. A curva padrão apresentou eficiência 1.0744 e a equação da curva foi: conc $=10^{\wedge}\left(-0.317^{*} \mathrm{CT}+9.729\right)$. Ao fim das reações de PCR o produto foi submetido a um teste da temperatura de melting do amplicon pelo aquecimento da reação de 60 a $98^{\circ} \mathrm{C}$, resultando em um pico na temperatura de $82.5^{\circ} \mathrm{C}$ na curva de melting com eixo Y definido como a derivada da fluorescência em função da temperatura (Figura 7 A). Esta curva e par de primers foram utilizados para quantificar o DNA viral intra e extracelular de infecções de $A g \mathrm{MNPV}$ recombinante contendo o gene fluc.

Para realizar a curva padrão do gene iel de $A c \mathrm{MNPV}$, primeiramente o fragmento de 198 pb amplificado a partir do genoma de AcMNPV foi clonado no plasmídeo pCR2.1TOPO (formando o plasmídeo pCR2.1-TOPOIE1qPCR, vetor 3931 + inserto 198 pb, 4129 pb, 1 ng de DNA = 220906082 cópias por ng) que utiliza a reação de ligação de ácidos nucleicos mediada pela topoisomerase seguindo o protocolo do fornecedor (Invitrogen). Este plasmídeo foi então diluído em água livre de RNAse e utilizado para realizar uma curva padrão para o gene iel como feito anteriormente. Os primers utilizados, AcNPVIE1qPCRFWR e AcNPVIE1qPCRREV, tem como alvo o gene iel do 
AcMNPV e suas sequências estão apresentadas na Figura 7. A curva padrão apresentou os seguintes parâmetros: threshold 0.023 , eficiência 1.03677 e equação da curva: conc= $10^{\wedge}\left(-0.309^{*} \mathrm{CT}+9.396\right)$. A curva de melting revelou uma temperatura $83.3^{\circ} \mathrm{C}$ (Figura 7 B). Apenas as amostras com o DNA viral intracelular contido nas linhagens Tn5B, S2 e MdE infectadas com AcMNPV wild-type foram avaliadas utilizando este par de primers e curva padrão.
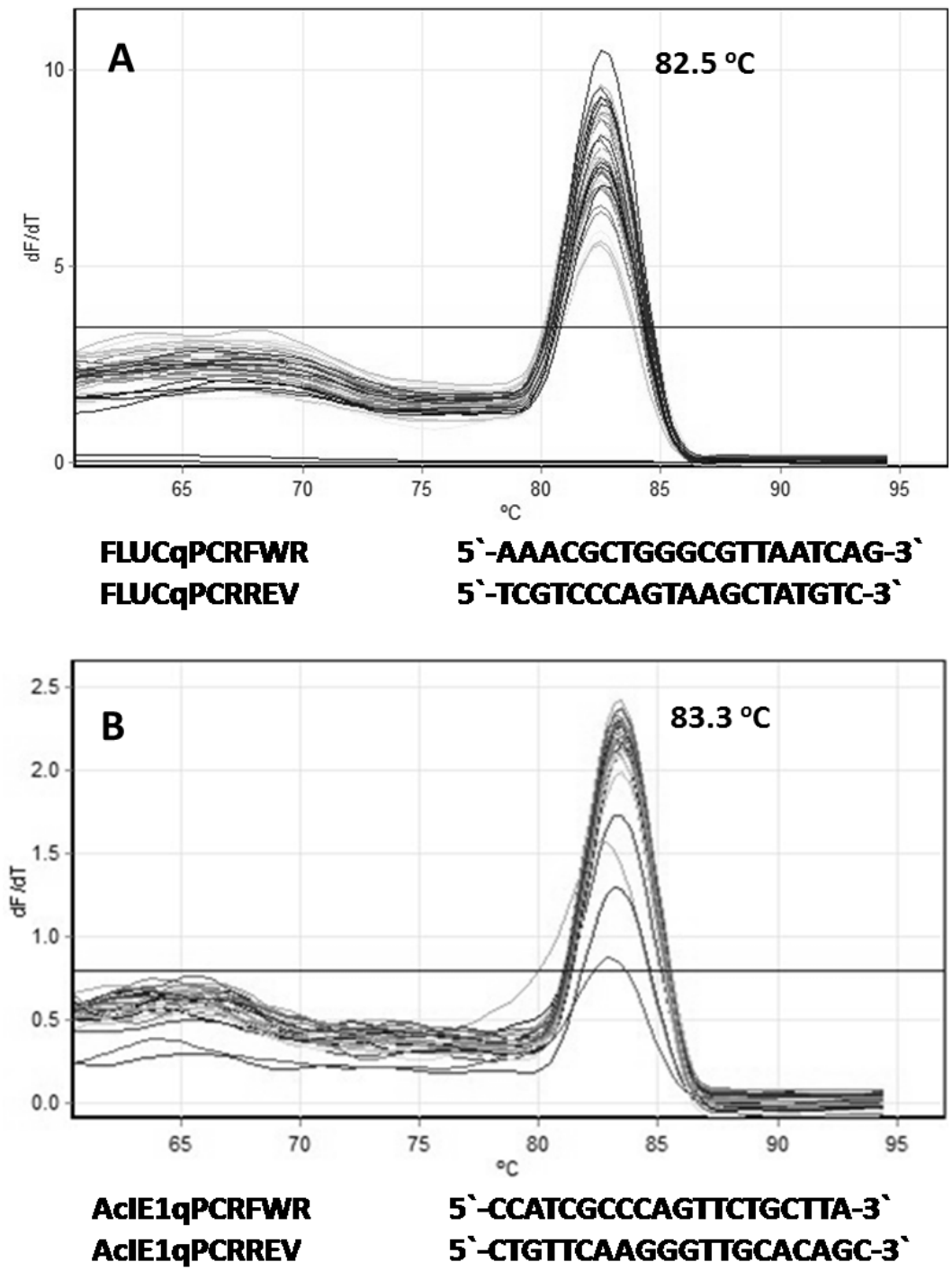

Figura 7: Curvas de melting de amplificações do gene fluc e a sequência de nucleotídeos dos primers utilizados nas reações de qPCR utilizando materiais de infecções com os baculovírus AgMNPV recombinantes contendo os genes fluc (A). Curvas de melting de amplificações do gene ie1 de AcMNPV e a sequência de nucleotídeos dos primers utilizados nas reações de qPCR de infecções de células com o AcMNPV (B). 
1.8. Quantificação do DNA viral extracelular (BVs) obtido a partir de células de inseto infectadas in vitro através de PCR em tempo real

Para quantificar o DNA viral extracelular, o sobrenadante de cada triplicata por tempo, que foi coletado das infecções da seção 3.7, foi levemente centrifugado $(1000 \times g$ / 10 min) para remover células e restos celulares, em seguida um volume do sobrenadante passa por uma extração de DNA viral livre de células baseada em Mukawa \& Goto (2006).

A partir de $30 \mu 1$ do sobrenadante foram adicionados $70 \mu 1$ de PBS e em seguida, a solução foi centrifugada a 1000 x $g$ por 10 min para coletar restos celulares e células em suspensão. Ao sobrenadante desta centrifugação foram adicionados $125 \mu 1$ de TE, 125 $\mu \mathrm{l}$ de SDS $2 \%$ e $5 \mu \mathrm{l}$ de Proteinase $\mathrm{K}(10 \mathrm{mg} / \mathrm{ml})$ e incubado por $16 \mathrm{~h}$ em temperatura ambiente. Após a incubação, $100 \mu \mathrm{l}$ de acetato de amônia $(4 \mathrm{M})$ foi adicionado e a solução foi misturada por inversão para homogeneizar e facilitar precipitação de proteínas. A solução foi centrifugada por 10 min a 12000 x $g$ a $4{ }^{\circ} \mathrm{C}$. O sobrenadante foi separado e o DNA foi precipitado pela adição de 2 volumes de álcool etílico absoluto e centrifugação a $12000 \times \mathrm{g}$ / $10 \mathrm{~min}$. O precipitado de DNA foi ressuspendido em $10 \mathrm{ul}$ de TE.

A PCR em tempo real foi realizada como descrito na seção anterior, utilizando os primers específicos ao gene iel de AcMNPV (Figura 7), com a única diferença que neste experimento apenas $3 \mathrm{ng}$ de DNA total foi utilizado por reação de qPCR (ao invés de 10 ng).

\subsection{Ensaio de fusão celular mediada pela proteína de envelope GP64 contida nos BVs sobre a linhagem MdE em baixo pH}

Este experimento teve como objetivo responder a questão se as partículas extracelulares do baculovírus $A c$ MNPV são capazes de adsorver na membrana celular da linhagem derivada de vespa MdE. Observa-se por microscopia de luz se ocorreu fusão 
entre as células próximas, após adição dos BVs, e troca do meio de cultura por um com pH 5.

Para realizar este ensaio, $5 \times 10^{5}$ células $\mathrm{MdE}$ foram semeadas por poço em placa de 6 poços e $1 \mathrm{ml}$ de meio Sf900-II pH 6.2 foi adicionado. A placa foi incubada por $2 \mathrm{~h}$ a $27{ }^{\circ} \mathrm{C}$ para que as células aderissem ao poço. Após a incubação, 3 tratamentos distintos foram realizados: o primeiro envolveu a adição do vírus BACAcIE1FLUC em MOI 100 sobre as células, incubação por $1 \mathrm{~h}$ a $27^{\circ} \mathrm{C}$ para adsorção do vírus na membrana celular e depois remoção deste meio com excesso de BVs não adsorvidos, adcionando meio Sf900-II com pH 5; o segundo tratamento ocorreu com a adição dos BVs em MOI 100 e troca de meio para um meio com pH 6.2 (sem choque de $\mathrm{pH}$ ); o terceiro tratamento não houve a adição dos BVs, mas com a troca de meio de cultura para um meio com pH 5.

A placa foi incubada em temperatura ambiente por $1 \mathrm{~h}$ e a fusão celular foi acompanhada e fotografada por inspeção visual em um microscópio Leica ao longo de 60 min em campo claro com anel de difração (2B) e objetiva de 20 x. 


\section{RESULTADOS E DISCUSSÃO}

\subsection{O programa de expressão gênica do baculovírus $A g M N P V$ durante a infecção de células de inseto derivadas de Lepidoptera}

A infecção celular dos baculovírus é coordenada temporalmente pelo controle transcricional dos genes virais (Rohrmann, 2013), sendo que a sequência de ativação dos genes virais tem relação direta com a função destes dentro da infecção de forma a coordenar o controle e manipulação da célula hospedeira para formar a sequência de dois fenótipos virais distintos (Iwanaga et al., 2004; Jiang et al., 2006). Considerando a sequência de ativação e intensidades relativas, os resultados obtidos de expressão gênica derivada dos promotores isolados em diferentes linhagens celulares indicam que a permissividade a infecção, isto é, a capacidade do vírus de produzir progênie infectiva em determinada linhagem celular ou tecido não é uma condição "tudo ou nada", conforme os perfis de expressão dos promotores como um todo são distintos entre as distintas linhagens infectadas. Portanto existem variadas condições de permissividade relativas à incapacidade do vírus em seguir a coordenada sequência de expressão gênica que garante sucesso na replicação gênica e formação de estruturas virais e efetiva proliferação do vírus (Morris \& Miller, 1992; 1993).

Tendo em vista o limitado espectro de células hospedeiras, a infecção de diferentes linhagens celulares realizadas neste trabalho utilizando os baculovírus AgMNPV recombinantes contendo o gene repórter fluc sobre o controle de diversos promotores nos fornece mais subsídios para compreender a natureza das infecções bem sucedidas e as infecções abortivas e tentar elucidar melhor como e quando ocorrem os bloqueios à infecção viral. 
A ativação dos promotores imediatamente precoces (prIE1, prGP64) significa que o vírus foi capaz de entrar na célula, ser transportado ao núcleo celular, ser desnudado e seu DNA ser reconhecido pela maquinaria celular de transcrição (Kovacs et al, 1992; Choi \& Guarino, 1995). Os promotores precoces atrasados (prLEF1, prVP39) são transativados pela proteína viral IE1 e indicam o início do estabelecimento da infecção pela expressão de genes auxiliares à replicação e transcrição dos gene tardios (Rodems et al, 1997; Sokal et al, 2014). A ativação dos promotores tardios (prP6.9, prVP39) e muito tardios (como prPOLH) indicam que a RNA polimerase viral foi expressa e a replicação do DNA viral está ocorrendo. A hiperexpressão a partir desses promotores indica que a célula já está controlada e pronta a produzir progênie viral (Todd et al, 1995; LaCount \& Friesen, 1997).

Existem indícios que o $A g M N P V$ é um baculovírus com um limitado espectro de hospedeiros in vivo. A infecção oral de larvas A. gemmatalis (Lepidoptera:Noctuidae) com OBs de $A g M N P V$ requer uma dose extremamente baixa para induzir morte $\left(\mathrm{LD}_{50}=\right.$ 4 OBs por larva, $\left.96 \quad \mathrm{OBs} / \mathrm{cm}^{2}\right)$. Enquanto em larvas $T . \quad n i$ (Lepidoptera:Noctuidae:Plusiinae) a dose letal é 100 vezes maior $\left(1.1 \times 10^{4} \mathrm{OBs} / \mathrm{cm}^{2}\right)$ (Grasela et al, 1998). As espécies T. ni e A. gemmatalis são polífagas e comumente encontradas em leguminosas, sendo que $T$. $n i$ tem preferência por couve, brócoli e alface (Waters \& Barsfield, 1989) enquanto A. gemmatalis prefere a planta da soja (Panizzi et al, 2004). Ambas espécies têm como hospedeiros vegetais alternativos, o algodão, a ervilha e o tabaco. Pela presença das duas espécies em uma mesma área e pela ampla utilização do $A g \mathrm{MNPV}$ nas últimas quatro décadas como bioinseticida, é possível afirmar que o baculovírus $A g \mathrm{MNPV}$ teve muitas oportunidades de infectar e utilizar $T$. ni, e outras espécies, como hospedeiro. No entanto, o que é observado é que $T$. $n i$ é naturalmente resistente à infecção oral de $A g \mathrm{MNPV}$. 
O cultivo de soja no Brasil nos últimos anos vem sofrendo com a ascenção de uma nova praga, a espécie Chrysodeixes includens (Lepidoptera:Noctuidae:Plusiinae), que apresenta uma resistência à infecção oral de $A g M N P V$ ainda mal caracterizada, mas óbvia devido à observação que $C$. includens ocorre em áreas em que $A g \mathrm{MNPV}$ foi disseminado como bioinseticida (Cota, 2015). Quando a infecção por baculovirus é iniciada pela injeção de BVs diretamente na hemolinfa de larvas de diferentes espécies, ocorre uma expansão do espectro de hospedeiros. Larvas de Spodoptera frugiperda (Lepidoptera:Noctuidae) são resistentes à infecção oral pelos baculovírus $A c \mathrm{MNPV}$ (Clem \& Miller, 1993) e $A g M N P V$ em altas doses, mas pela injeção intrahemocélica de BVs é possível causar infecção sistêmica e morte (resultados não publicados). Este padrão de restrição da infecção oral está relacionada a mecanismos físicos e químicos de defesa do hospedeiro.

A infecção oral deve proceder por diversos tecidos sucessivamente para resultar em uma infecção sistêmica do organismo, desde células colunares do epitélio do intestino médio, traqueoblastos, células livres da hemolinfa e tecidos em contato com a hemolinfa (Rohrmann, 2013; Asser-Kaiser et al, 2011; Passarelli, 2011). Existem casos relatados de bloqueio da infecção oral primária ainda nas células epiteliais do intestino (HaasStapleton et al, 2005). Em outras situações a infecção primária é bem sucedida mas ocorrem bloqueios na proliferação da infecção em tecidos abundantes como tecido gorduroso e células da hemolinfa o que impede que a infecção sistêmica seja total no organismo e cause morte ao hospedeiro. Até mesmo em hospedeiros suscetíveis em que a infecção sistêmica prolifera e mata o organismo observa-se que alguns tecidos praticamente não suportam a replicação do DNA viral (Chikhalya et al, 2009; Soares \& Ribeiro, 2005, Cordeiro et al., 2008). 
A infecção de $A g M N P V$ em células de inseto cultivadas in vitro também demonstra um espectro limitado de hospedeiros mas sem padrões reconhecíveis relacionados às espécies-famílias de onde as linhagens foram originadas (Lynn, 2003). Poucos estudos foram realizados testando um baculovírus contra uma ampla gama de linhagens celulares. Um estudo de permissividade da infecção de $A g M N P V$ em diferentes linhagens foi conduzida por Castro et al (1997) e Castro et al (2006) avaliando a infecção por microscopia de luz, análise da replicação de DNA viral, titulação dos fenótipos produzidos e produção de proteínas induzidas pelo vírus. O trabalho mostrou que as linhagens UFLAg e Tn5B são completamente suscetíveis à infecção viral, devido à produção em grande quantidade de BVs e OBs ao longo da infecção. A linhagem Sf9 foi considerada semipermissiva devido à reduzida produção de BVs infectivos e OBs. As linhagens Ld652Y e Bm5 foram caracterizadas como não permissivas devido à incapacidade de formação de OBs e baixa replicação do vírus.

Não existe relação direta entre a permissividade in vivo e in vitro. As células em cultura derivadas de um inseto suscetível não necessariamente serão suscetíveis à infecção por um baculovírus. Como as linhagens celulares de insetos costumam ser derivadas de tecidos específicos de larvas ou em alguns casos derivadas de ovos ou adultos ao invés de larvas, além da passagem seriada em meio de cultivo para adaptação, ocorre então uma seleção de linhagens com maior habilidade de crescimento in vitro, potencialmente em detrimento da permissividade a infecção viral (Lynn, 2003). Portanto a permissividade de linhagens celulares à infecção in vitro é potencialmente distinta da permissividade do hospedeiro pela infecção oral in vivo. Além disto, nem todos tecidos de um hospedeiro considerado suscetível à infecção oral são naturalmente permissivos à infecção (tropismo celular, Wang et al., 2008) o que indica que apenas o conteúdo genético da célula hospedeira não é suficiente para determinar permissividade. Os 
elementos genéticos e metabólicos que garantem a permissividade ou não de linhagens celulares e tecidos à infecção baculoviral oferecem um mosaico de difícil compreensão nos estudos de permissividade.

Para melhor compreender a questão da permissividade de linhagens celulares cultivadas in vitro à infecção pelo $A g \mathrm{MNPV}$, duas metodologias de quantificação da expressão de promotores virais de diferentes fases da infecção utilizando a quimioluminescência do gene $f l u c$ foram utilizadas. A quantificação pelo método de lise envolve a medição da produção do gene repórter ao longo do tempo utilizando triplicatas independentes para cada tempo (seção cruzada). A quantificação pelo método em tempo real envolve a medição da luminescência da mesma população de células ao longo do tempo em triplicatas (longitudinal). Esta segunda metodologia foi desenvolvida e otimizada ao longo deste trabalho e se revelou como uma forma de observação dos fenômenos de expressão gênica viral muito dinâmica e prática.

O método padrão de medição de quimioluminescência derivada da enzima FLUC segue o procedimento recomendado pelo kit Luciferase Assay System (Promega), que basicamente envolve lisar as células infectadas e medir a luminescência presente naquele momento. O maior benefício desta metodologia é a capacidade de normalização do valor de luminescência pelo total de proteínas, o que aumenta a confiabilidade na comparação entre tratamentos. Estes ensaios foram realizados utilizando $A g \mathrm{MNPV}$ s recombinantes em MOI 10 nas células UFLAg, Tn5B, Sf9 e Ld652Y. Os gráficos estão dispostos na figura 8. 

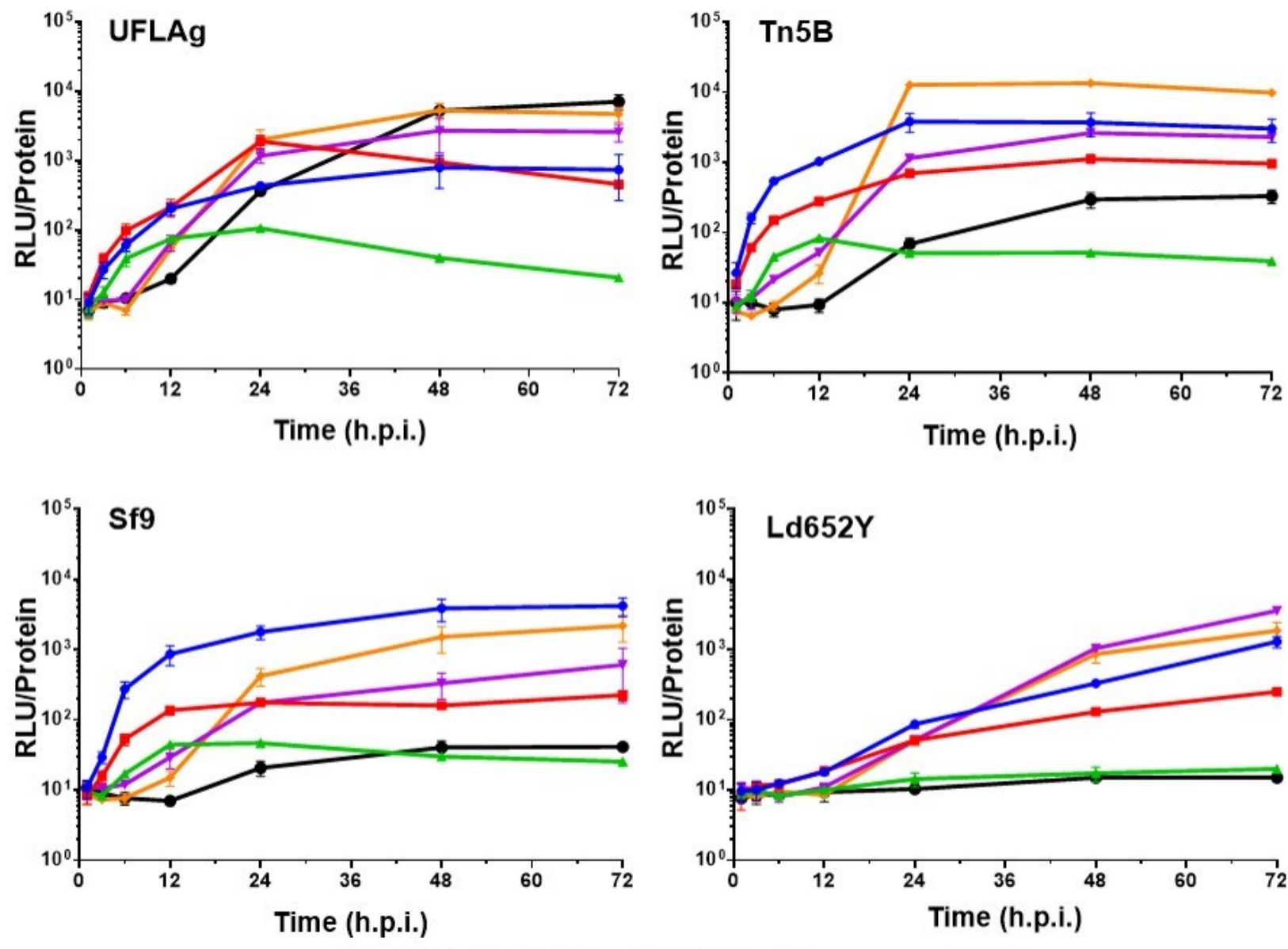

- IE1 - GP64 - LEF1 - VP39 - P6.9 - POLH

Figura 8: Ensaio padrão de medição de quimioluminescência de células infectadas com AgMNPV recombinantes. As linhagens testadas foram UFLAg, Tn5B, Sf9 e Ld652Y em MOI 10. Os pontos de medição foram 1, 3, 6, 12, 24, 48 e $72 \mathrm{~h}$ p.i.. $\mathrm{O}$ ensaio foi realizado em triplicatas, apresentando a média e desvio padrão em relação à média. Eixo $\mathrm{Y}$ em escala logarítmica.

Os perfis de expressão dos promotores de $A g \mathrm{MNPV}$ nas células UFLAg, Tn5B e Sf9 apresentaram características comuns, como a ativação de todos os promotores dentro das primeras 15 h p.i., o alcance do pico de luminescência até 48 h p.i. seguidos por um platô no nível de luminescência. A sequência de ativação destes também foi similar entre as linhagens celulares: nas primeiras 3 h p.i.: prAgIE1, prAgGP64; de 3 a 9 h p.i.: prAgLEF1, prAgVP39 e prAgP6.9; a partir de 12 h p.i.: prAgPOLH. Todas ativações ocorrem dentro de $12 \mathrm{~h}$ p.i.. Os promotores considerados tardios e muito tardios apenas são ativados a partir de 6 h p.i., o que é consistente com as observações de que a replicação 
do DNA viral ocorre a partir deste momento e a ativação destes elementos é dependente da replicação viral (Rapp et al, 1998; Todd et al, 1995). Esta última observação, referente à detecção de expressão a partir dos promotores tardios após 9 h p.i. indica que as linhagens UFLAg, Tn5B e Sf9 iniciam a replicação do DNA viral entre 6 e 9 h p.i.. Em contrapartida, a linhagem celular Sf9 apresentou expressão reduzida (abaixo da expressão de pr $A g$ IE1) dos promotores tardios $A g$ VP39 e $A g$ P69 e expressão fraca do promotor AgPOLH, indicando que mesmo sendo capaz de replicar o DNA viral, a expressão do promotor muito tardio é muito fraca.

Dentro das 72 h p.i. avaliadas, os promotores precoces não apresentaram clara redução de luminescência após atingir o pico de expressão. Um processo esperado devido à hipótese de que promotores precoces são "desligados" após entrar na fase tardia da infecção (Pinedo, 2004). Apenas em UFLAg os promotores AgGP64 e AgLEF1 apresentaram uma redução de RLU, as demais configurações de promotores e linhagens mostraram um sinal estável após o pico de expressão. Os promotores com maior pico de expressão em UFLAg foram: prAgVP39, prAgP6.9 e prAgPOLH (Figura 8). A linhagem celular Ld652Y apresentou uma expressão diferenciada, com retardo no início da expressão dos promotores $A g I E 1$ e $A g$ GP64, detectados a partir de 12 h p.i., e detecção de prAgVP39 e prAgP6.9 entre 12 e 24 h p.i.. Os promotores $A g L E F 1$ e $A g$ POLH não foram ativados nesta linhagem celular.

Devido à coleta fixa de pontos de medição a cada 3 horas, não foi possível distinguir precisamente o primeiro momento de detecção de $\operatorname{pr} A g I E 1$ e pr $A g$ GP64, ambos ativados entre a primeira e terceira h p.i., assim como pr $A g$ VP39 e pr $A g L E F 1$, ativados entre a terceira e sexta h p.i..

O ensaio de medição contínua tem como princípio a adição de D-luciferina ao meio de cultivo das células e obtenção em tempo real da luminescência derivada da 
infecção celular e expressão gênica da enzima Luciferase. Esta metodologia é muito prática pois permite a automatização e a flexibilização do procedimento de coleta de dados. As medições foram programadas para serem realizadas a cada 999 s (limite máximo permitido pela máquina, aproximadamente a cada $15 \mathrm{~min}$ ) durante os 3 primeiros dias de infecção e a partir deste período as coletas foram feitas ad hoc, sem períodos específicos. Apesar de os dados terem sido coletados usando os intervalos de $15 \mathrm{~min}$ citados, a apresentação em gráficos não permite a exposição de todos os pontos de coleta pois isto sobrecarrega a imagem com excesso desnecessário de pontos e barras de erro padrão, portanto dependendo do tempo total de infecção apresentado no gráfico os intervalos são ajustados para melhorar a qualidade de visualização.

Diferente do que é recomendado usualmente para ensaios de quimioluminescência, nesta metodologia foram utilizadas placas pretas opacas ao invés de placas brancas, que permitem maior reflexão do sinal luminoso derivado da quimioluminescência, devido à observação de que a intensa luminescência derivada dos promotores tardios pode vazar para poços próximos devido à reflexão da placa branca. $\mathrm{O}$ uso de placas escuras elimina completamente o vazamento de sinal de um poço aos imediatamente próximos, mesmo quando os valores são da magnitude $10^{5}$ RLU.

Em todos os experimentos de medição contínua, o valor de baseline ou valor de background de luminescência foi definido com base em valores obtidos de poços sem células, com células não infectadas e com células infectadas com baculovírus que não expressam FLUC. A partir disto, foi determinado que o valor mínimo para considerar um sinal positivo de Luciferase é de 20 RLU.

A infecção em MOI 10 das células UFLAg, Tn5B, Sf9, Ld652Y, Chch e Bm5 revelou perfis distintos de expressão dos promotores virais entre a infecção de células permissivas UFLAg e Tn5B com a ativação de todos os promotores dentro de $12 \mathrm{~h}$ p.i. e 
subsequente hiperexpressão dos promotores tardios (atingindo picos de expressão entre $10^{4}$ e $10^{5}$ RLU). Os resultados ao longo de 4 dias de infecção apresentados nas figuras 9 e 10, estão em consonância com os obtidos pelo ensaio padrão em magnitude e temporalidade, no entanto o alto grau de resolução da medição contínua permitiu a observação de detalhes antes ocultos. Para melhor visualização do primeiro dia de infecção e a resolução da técnica dentro deste período, os gráficos foram plotados realçando as primeiras 24 h p.i. nas figuras 9 e 10. 

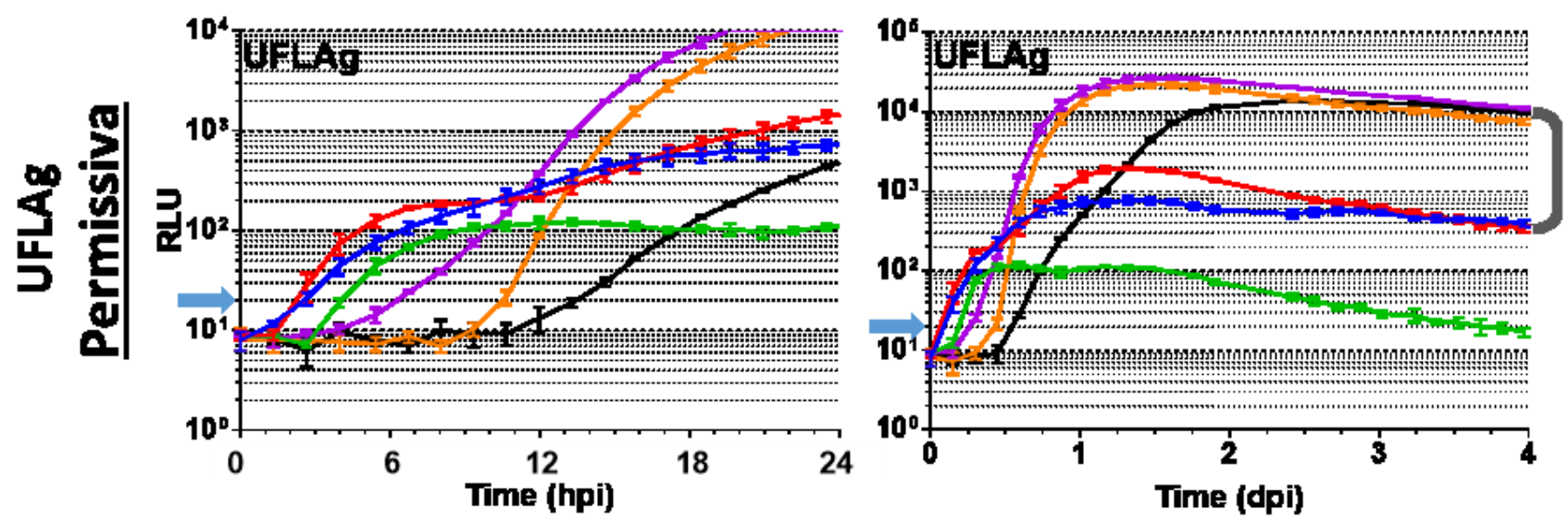

Hyperexp.+ Replic. +

BV + OB +
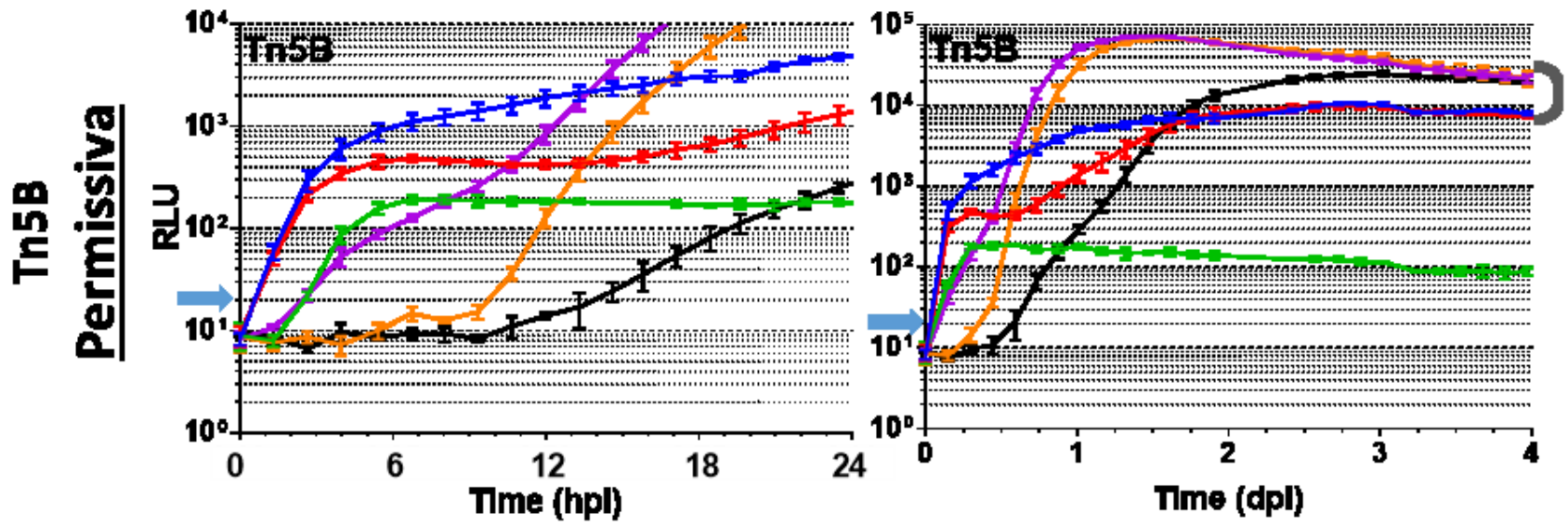

Hyperexp. + Replic. + BV + OB +
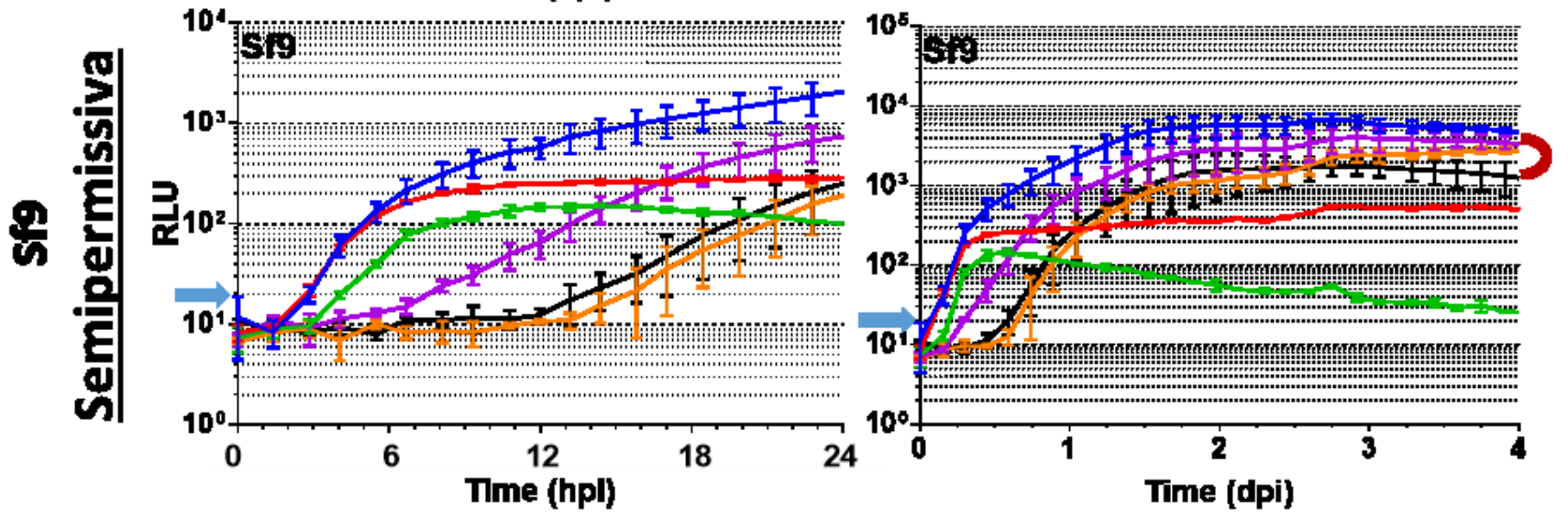

Hyperexp. Replic. + BV + OB +

\section{- IE1 - GP64 - LEF1 - VP39 - P6.9 - POLH}

Figura 9: Ensaios de medição contínua de luminescência nas linhagens UFLAg, Tn5B, Sf9, Ld652Y, Chch e Bm5 durante 4 dias de infecção com os baculovírus $A g M N P V$ recombinantes em MOI 10. Os intervalos apresentados são de 3 horas entre medições. As setas azuis próximas ao eixo $Y$ indicam o nível basal de luminescência (20 RLU). As medições são apresentadas como média de triplicatas e barras de erro representam o desvio padrão. 

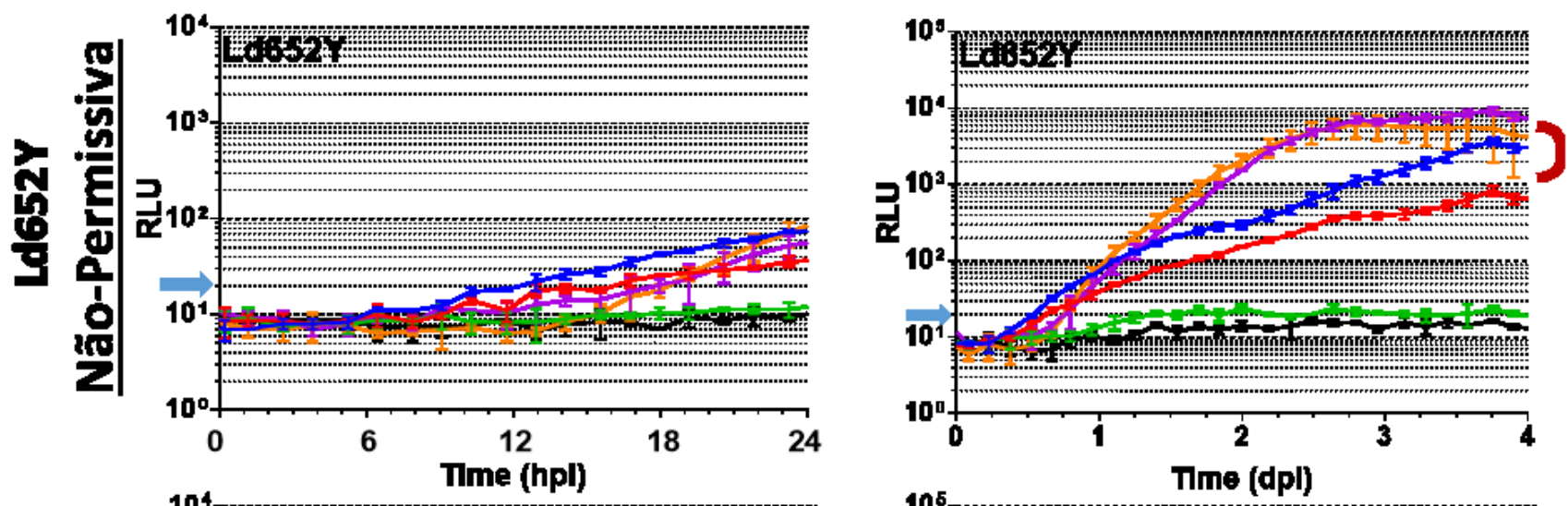

Hyperexp. Replic. + BV OB -
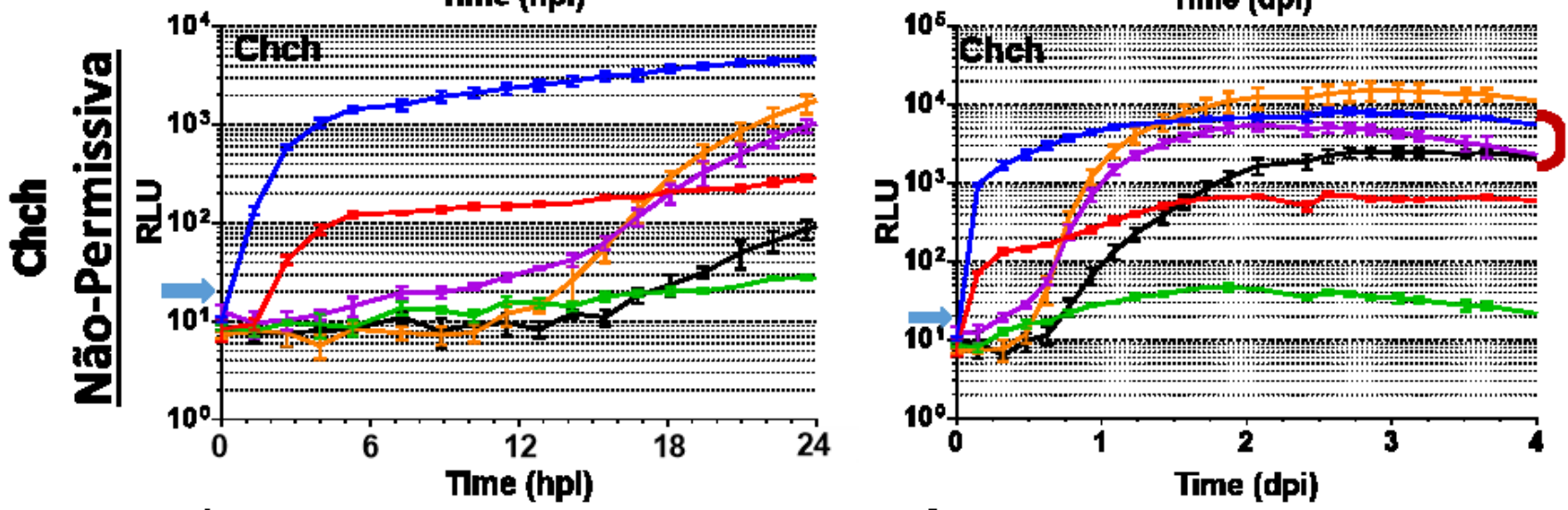

\section{Hyperexp. -} Replic. + BV OB -
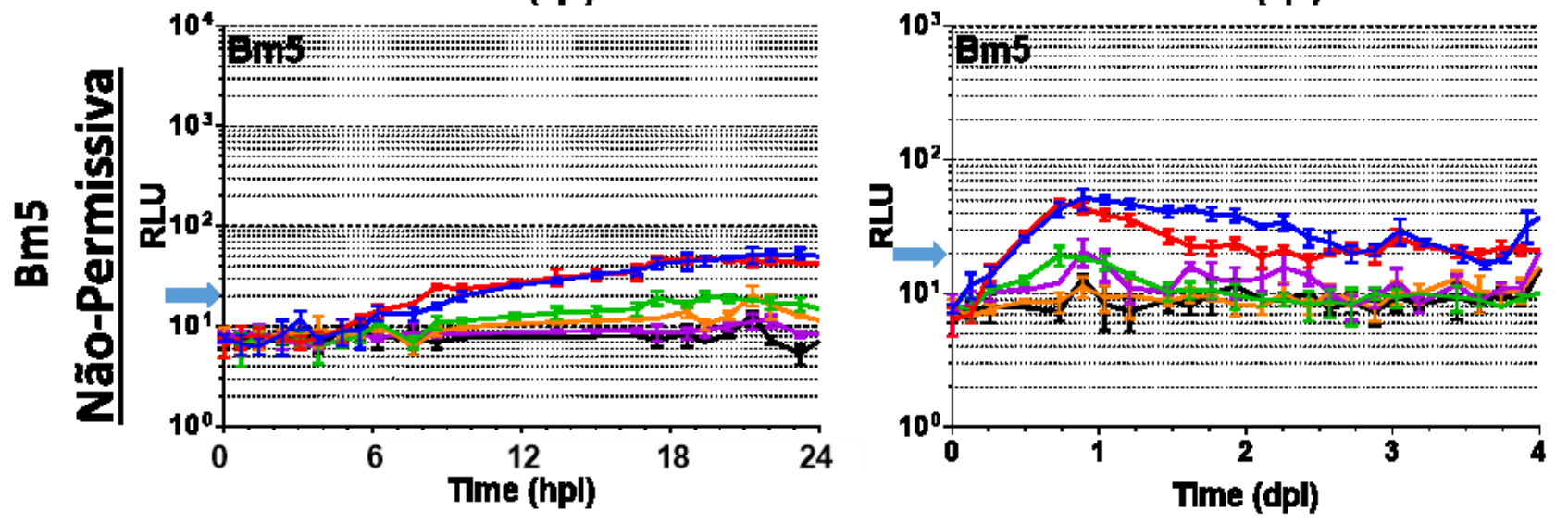

\section{Hyperexp. -} Replic. BV -
OB -

\section{- IE1 - GP64 - LEF1 - VP39 - P6.9 - POUH}

Figura 10: Ensaios de medição contínua de luminescência nas linhagens UFLAg, Tn5B, Sf9, Ld652Y, Chch e Bm5 durante 4 dias de infecção com os baculovírus $A g M N P V$ recombinantes em $\mathrm{MOI} 10$. Os intervalos apresentados são de 3 horas entre medições. As medições são apresentadas como média de triplicatas e barras de erro representam o desvio padrão. 
O perfil de expressão dos promotores em células permissivas, semipermissivas e não-permissivas durante a infecção indicou que a sequência de ativação dos promotores é comum entre todas as linhagens (prIE1, prGP64, prLEF1, prVP39, prP6.9 e prPOLH, Tabela 2). Sendo que nas linhagens permissivas a expressão tardia atinge $V_{\max } 10$ vezes maior que a expressão dos promotores precoces (Tabela 3). Ambas observações são equivalentes às realizadas em estudos da transcrição gênica de outros baculovírus (Chen et al., 2013; Iwanaga et al., 2004; Jiang et al., 2006; Morris \& Miller, 1992).

Tabela 2: Tempo de primeira detecção ( $\left.T_{\text {in }}\right)$ do sinal de luminescência (hh:mm)

\begin{tabular}{ccccccc}
\hline Linhagem & \multicolumn{7}{c}{ Vírus } \\
\hline & $\begin{array}{c}\text { IE1FLUC } \\
\text { Média }\end{array}$ & $\begin{array}{c}\text { GP64FLUC } \\
\text { Média }\end{array}$ & $\begin{array}{c}\text { LEF1FLUC } \\
\text { Média }\end{array}$ & $\begin{array}{c}\text { VP39FLUC } \\
\text { Média }\end{array}$ & $\begin{array}{c}\text { P6.9FLUC } \\
\text { Média }\end{array}$ & $\begin{array}{c}\text { POLHFLUC } \\
\text { Média }\end{array}$ \\
\hline UFLAg & $1: 58$ & $2: 03$ & $3: 42$ & $5: 35$ & $10: 10$ & $12: 49$ \\
Tn5B & $0: 27$ & $0: 32$ & $2: 15$ & $2: 03$ & $9: 08$ & $13: 17$ \\
Sf9 & $2: 03$ & $2: 03$ & $3: 51$ & $6: 39$ & $15: 08$ & $16: 53$ \\
Ld652Y & $11: 54$ & $13: 19$ & - & $17: 07$ & $17: 25$ & - \\
Chch & $1: 24$ & $1: 54$ & $17: 01$ & $8: 58$ & $13: 39$ & $17: 10$ \\
Bm5 & $8: 30$ & $6: 46$ & - & - & - & - \\
\hline
\end{tabular}

Tabela 3: Tempo até atingir pico $\left(T_{\mathrm{pi}}\right)$ de expressão do sinal de luminescência (hh:mm)

\begin{tabular}{ccccccc}
\hline Linhagem & \multicolumn{7}{c}{ Vírus } \\
\hline & $\begin{array}{c}\text { IE1FLUC } \\
\text { Média }\end{array}$ & $\begin{array}{c}\text { GP64FLUC } \\
\text { Média }\end{array}$ & $\begin{array}{c}\text { LEF1FLUC } \\
\text { Média }\end{array}$ & $\begin{array}{c}\text { VP39FLUC } \\
\text { Média }\end{array}$ & $\begin{array}{c}\text { P6.9FLUC } \\
\text { Média }\end{array}$ & $\begin{array}{c}\text { POLHFLUC } \\
\text { Média }\end{array}$ \\
\hline UFLAg & $32: 15$ & $31: 58$ & $18: 41$ & $36: 58$ & $34: 54$ & $59: 24$ \\
Tn5B & $66: 25$ & $65: 19$ & $12: 31$ & $36: 05$ & $38: 26$ & $72: 10$ \\
Sf9 & $63: 09$ & $76: 49$ & $12: 45$ & $76: 01$ & $89: 47$ & $69: 21$ \\
Ld652Y & $109: 18$ & $110: 59$ & - & $90: 30$ & $74: 45$ & - \\
Chch & $62: 47$ & $48: 56$ & $48: 02$ & $48: 56$ & $68: 31$ & $67: 12$ \\
Bm5 & $57: 33$ & $17: 57$ & - & - & - & - \\
\hline
\end{tabular}

A infecção do $A g \mathrm{MNPV}$ em células permissivas Tn5B e UFLAg tem como pontos de referência: a rápida ativação dos promotores precoces (prAgIE1, prAgGP64, prAgLEF1 e prAgVP39) antes de 6 h p.i., a ativação da hiperexpressão dos promotores $\operatorname{pr} A g$ VP39 (bimodal) e pr $A g$ P6.9 (tardio) a partir de 8 h p.i., com pico de expressão às 24 
h p.i. e com valores pelo menos 10 vezes superiores ao dos promotores precoces. Após 10 h p.i., inicia-se a expressão de prPOLH (muito tardio) que possui um aumento gradual mais lento que os tardios mas apresenta o mesmo pico de expressão atingido apenas em 48 h p.i. (Tabela 2$)$.

As linhagens permissivas UFLAg e Tn5B apresentaram os mais rápidos inícios de expressão dos promotores $\left(\mathrm{T}_{\text {in }}\right)$. Notavelmente o promotor $A g I E 1$ em Tn5B dentro de 30 min após a infecção e 2 h p.i. em UFLAg. A atividade de prAgGP64 não é distinta de $\operatorname{pr} A g I E 1$, ambos aqui observados como imediatamente precoces, durante as primeiras 14 h p.i. em Tn5B (Teste $t$ : diferenças entre $T_{\text {in }} p=0.23$, ANOVA 2-way: diferenças não significativas dentro das primeiras $14 \mathrm{~h}$ p.i.) e $19 \mathrm{~h}$ p.i. em UFLAg (Teste $\mathrm{t} \mathrm{T}_{\text {in }} \mathrm{p}=0.72$, ANOVA 2-way: diferenças não significativas dentro das primeiras $19 \mathrm{~h}$ p.i.). O promotor LEF1 por outro lado apresentou $\mathrm{T}_{\text {in }}$ distinto de prAgIE1 e pr $A g$ GP64 (Teste $\mathrm{t}$ da diferença entre $T_{\text {in }} \mathrm{p}<0.0002$ em UFLAg, Tn5B e Sf9). A sua atividade foi limitada, atingindo os valores mais baixos de expressão dentre todos promotores, indicaram que este promotor possui mecanismos distintos de expressão em comparação aos promotores imediatamente precoces. Portanto, a correta classificação para o promotor $\operatorname{pr} A g L E F 1$ seria a classe delayed early (precoce atrasada), não dependente de replicação de DNA ou RNA polimerase viral.

As curvas de prAgGP64 apresentaram duas fases: a primeira entre $\mathrm{T}_{\text {in }}$ e $12 \mathrm{~h}$ p.i. seguidos por uma segunda fase até atingir o pico de expressão $\left(T_{\mathrm{pi}}\right)$ às $31 \mathrm{~h}$ p.i. em UFLAg e 65 h p.i. em Tn5B. Esta segunda fase de aumento está associada a ativação dos motivos de transcrição tardios contidos em prAgGP64 pela RNA pol viral presente e em paralelo à replicação do DNA viral, tais motivos são inexistentes em pr $A g I E 1$. Isto classifica o promotor GP64 como bimodal (imediatamente precoce e tardio). Desta forma, foram observadas de forma inédita a distinção temporal entre prAgIE1 e prAgGP64, 
classificados então como imediatamente precoces enquanto prAgLEF1 e prAgVP39 foram classificados como precoces atrasados.

Os promotores LEF1 e VP39 apresentaram $\mathrm{T}_{\text {in }}$ muito similares em UFLAg (Teste $\mathrm{t} p=0.008)$ e Tn5B $(\mathrm{p}=0.29)$, mas significativamente distintos em Sf9 $(\mathrm{p}<0.0001)$ indicando que prAgVP39 possui atividade em momentos delayed early, similar ao elemento precoce de pr $A g L E F 1$. Além disso, é importante notar que os promotores VP39 e P6.9 apresentaram $T_{\text {in }}$ significativamente distintos em UFLAg, Tn5B e Sf9 (Teste t $p<$ 0.0001). A diferença ocorre devido ao fato que prAgVP39 apresentou um momento de ativação precoce com sinal fraco mas distinto, $T_{\text {in }}$ de 5, 2 e 6 h p.i., em comparação ao momento de ativação nitidamente tardio de prAgP6.9 com $\mathrm{T}_{\text {in }}$ de 10, 9 e 15 h p.i. em UFLAg, Tn5B e Sf9, respectivamente. Isto é atribuído à presença de motivos de transcrição precoces contidos em prAgVP39 mas ausentes em prAgP6.9, classificando prAgVP39 como um promotor bimodal, precoce atrasado e tardio, enquanto prAgP6.9 é um promotor exclusivamente tardio. A subsequente hiperexpressão que ocorre em pr $A g$ VP39 e pr $A g$ P6.9 são similares a partir de 9 h p.i. e ambos promotores atingem picos de expressão $\left(\mathrm{V}_{\max }\right)$ equivalentes tanto em intensidade como em pico de expressão.

A expressão do prAgGP64 em momentos precoces funciona como um preparo prévio para receber as partículas virais que irão migrar para fora do núcleo até membrana celular em momentos tardios (Engelhard et al., 1994; Passarelli, 2011). A fraca expressão de prAgVP39 durante momentos precoces tem função similar de preparo para a replicação, mas este gene é encaminhado ao núcleo onde se associa ao DNA viral e contribui na formação do estroma virogênico, que é uma estrutura nuclear onde ocorre a replicação e formação das partículas virais (Nagamine et al., 2005). Ambos promotores tem uma característica de expressão bimodal como descrito, com dois momentos distintos de aumento de expressão. Com os dados de quantificação do DNA (Figura 13) observa- 
se que o segundo momento de aumento da expressão ocorre após o aumento da replicação viral, o que reforça o conceito da dependência da expressão gênica tardia e hiperexpressão resultante da replicação viral.

O promotor pr $A g \mathrm{POLH}$ apresentou um $\mathrm{T}_{\text {in }}$ distinto do promotor tardio P6.9 (Teste t: $\mathrm{p}<0.001$ em UFLAg e Tn5B). Além disto, a hiperexpressão de prAgPOLH é menos intensa que a de P6.9 ( $\mathrm{T}_{\mathrm{pi}} 37$ e 36 h p.i. em UFLAg e Tn5B), atingindo valores máximos $\left(\mathrm{V}_{\max }\right)$ inferiores e demorando mais tempo para atingir $\mathrm{T}_{\mathrm{pi}}(59$ e $72 \mathrm{~h}$ p.i. em UFLAg e Tn5B). Isto indica possivelmente que o mecanismo de expressão tardia de prAgP6.9 é distinta da ocorrida a partir de prAgPOLH. Portanto, uma distinção observada de forma muito clara nos momentos tardios foi entre prAgP6.9 (tardio) e prAgPOLH (muito tardio) com $T_{\text {in }}$ distintos, indicando a possibilidade de existência de mecanismos variados de expressão nos promotores da fase tardia e justificando a distinção entre tardios e muito tardios.

Ao comparar em paralelo as curvas de expressão gênica (Figura 9) com a replicação viral intracelular nas células permissivas Tn5B e UFLAg (Seção 4.1.1, Figura 13), torna-se evidente a distinção entre a fase precoce e tardia. Antes de $6 \mathrm{~h}$ p.i. apenas os promotores de genes associados a transativação e replicação são observados. Após $6 \mathrm{~h}$ p.i. observa-se a ascenção da concentração do DNA viral e simultaneamente a ativação e intensa transcrição dos promotores tardios. Desta forma, existe uma coordenação entre a replicação do DNA viral, a expressão gênica (em especial dos genes estruturais) e a formação do primeiro fenótipo viral, os vírus extracelulares (BVs). As curvas de detecção do vírus extracelular nestas linhagens permissivas demonstram que no intervalo entre 6 e 12 h p.i. não ocorre produção de BVs, o que é consistente com a observação de que neste período ainda existe baixa expressão dos promotores VP39 e P6.9, que controlam os componentes principais do capsídeo viral. Após 12 h p.i., é possível detectar o aumento 
gradual do título viral extracelular, o que caminha em conjunto com o aumento intenso da expressão dos dois promotores citados. As 24 h p.i., observa-se um platô na curva de DNA intracelular e simultaneamente o pico de expressão dos dois promotores. Até $48 \mathrm{~h}$ p.i. o aumento na produção de BVs continua. A partir de 48 h p.i. observa-se a formação de OBs no núcleo das células (Figura 11)

As linhagens com permissividade limitada Sf9, Ld652Y e Chch apresentaram uma replicação intracelular ativa apenas a partir de 12 h p.i. (Figura 13). Em nível de expressão gênica, o que estas linhagens tem em comum a 24 h p.i. é um nível de expressão de promotores precoces e tardios próximo a $10^{3} \mathrm{RLU}, 10$ vezes menor do que o nível das linhagens permissivas.

No caso da linhagem semipermissiva Sf9, apesar de todos promotores ativarem dentro de 6 h p.i., não ocorre a hiperexpressão dos promotores tardios como nas células permissivas UFLAg e Tn5B. A expressão relativa dos promotores com elementos tardios foi equivalente ao dos promotores precoces (ANOVA 2-way: diferenças não significativas entre todos promotores tardios e o promotor $A g I E 1$ entre 48 e 72 h p.i.), indicando falha na capacidade de hiperexpressão gênica. Estes resultados estão de acordo com a observação de uma produção reduzida de BVs e poliedros (Castro et al., 1997; Lynn, 2003) e observações da limitação da expressão de promotores muito tardios durante a infecção de $A c$ MNPV em células semi-permissivas (Morris \& Miller, 1992). Os dados de replicação em Sf9 corroboram estes pontos pois o intervalo entre início da replicação intracelular às $12 \mathrm{~h}$ p.i. e a primeira e nítida detecção dos BVs a 48 h p.i. correlaciona muito bem com os níveis inferiores de expressão dos promotores tardios nestes momentos. 


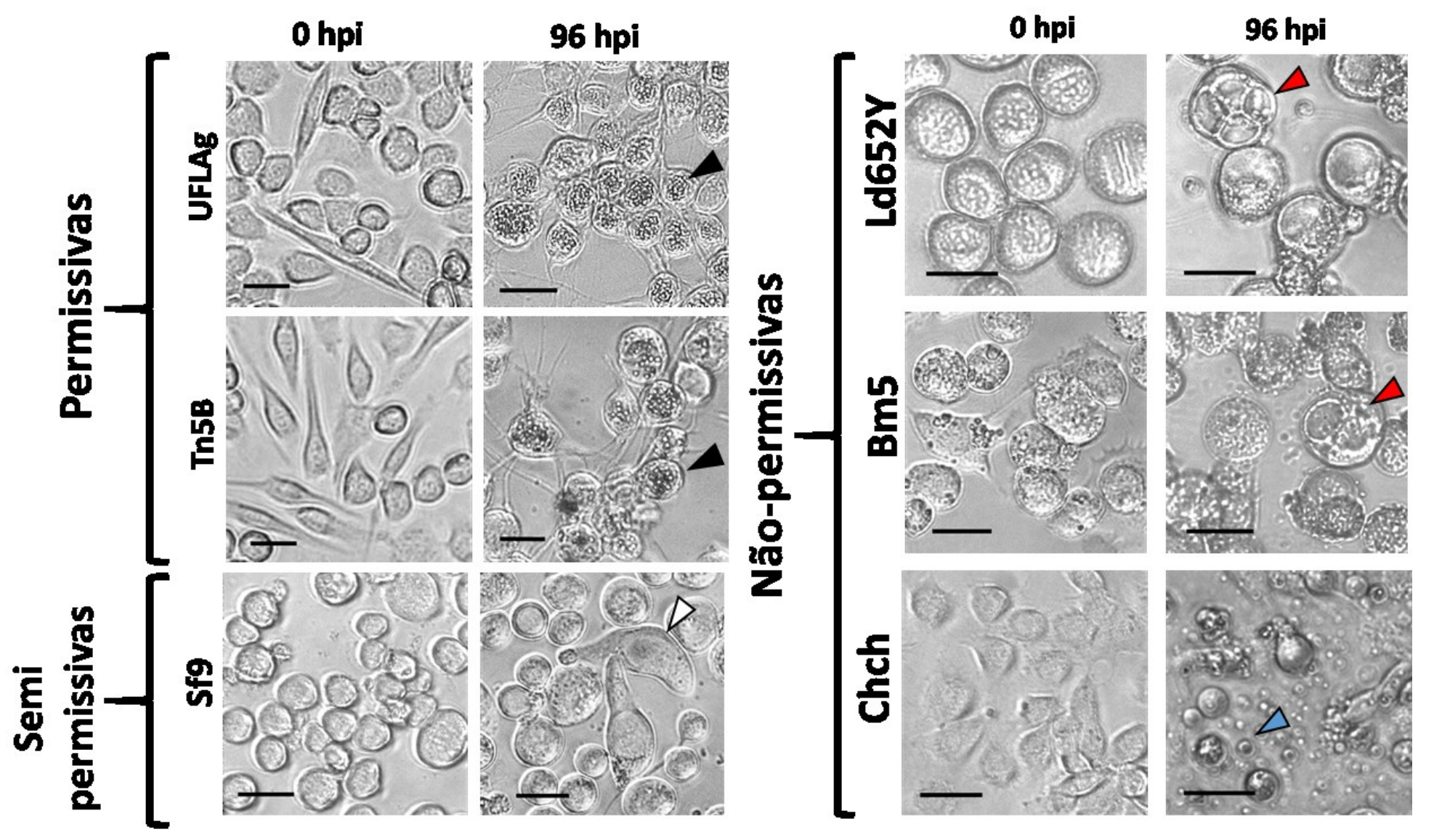

Figura 11: Micrografias das células UFLAg, Tn5B, Sf9, Ld652Y, Bm5 e Chch infectadas com o baculovírus recombinante vAgIE1FLUC às $0 \mathrm{~h}$ p.i. e $96 \mathrm{~h}$ p.i. Barras de dimensão representam $25 \mu \mathrm{m}$. Setas escuras indicam células infectadas com corpos de oclusão no núcleo. Setas brancas indicam células infectadas com núcleo dilatado, sem a presença de corpos de oclusão. Setas em vermelho indicam efeitos citopáticos como a vacuolização de células infectadas. Seta em azul indica corpos apoptóticos de células infectadas.

Em Ld652Y e Chch mesmo com a replicação intracelular funcional e expressão dos promotores tardios não foi detectado DNA viral extracelular até $48 \mathrm{~h}$ p.i.. A apoptose é um fenômeno raro em Ld652Y, já descrito anteriormente para a infecção do vírus Orgyia pseudotsugata MNPV (Ishikawa et al., 2003). No entanto, observamos efeitos citopáticos associados à necrose como a vacuolização das células (Figura 11, setas vermelhas). Portanto, é possível que o mecanismo de defesa celular que impede a formação de BVs de $A g M N P V$ também esteja associado ao bloqueio da tradução como descrito para AcMNPV (Thiem \& Chejanovsky, 2004). Em Chch a apoptose é proeminente em 24 h p.i., apresentando células em início de apoptose e inúmeros corpos apoptóticos. A replicação do vírus é considerado um dos ativadores do processo de 
apoptose durante a infecção (Du \& Thiem, 1997; LaCount \& Friesen, 1997), no entanto a apoptose não é suficiente para extinguir completamente a produção de BVs (Clem \& Miller, 1993; Castro \& Ribeiro, 2001). Neste trabalho, pelo menos até 48 h p.i. não foram detectados vírus extracelulares mas ainda é possível que apareçam em momentos posteriores. De qualquer forma, o processo apoptótico nitidamente afeta tanto a transcrição gênica tardia quanto a replicação viral intracelular.

As linhagens Ld652Y, Chch e Bm5 foram consideradas não-permissivas ao $A g \mathrm{MNPV}$ pela ausência de produção dos fenótipos infectivos, com base na quantificação por qPCR e outros estudos, complementam estas conclusões, com reservas, pela observação que em infecções abortivas pelo vírus $A g \mathrm{MNPV}$ não são detectados transcritos da fase tardia nas linhagens Ld652Y e Bm5 (Castro et al, 2006). Nenhuma destas células apresenta poliedros por inspeção visual das células em microscópio de luz às $96 \mathrm{~h}$ p.i. (Figura 11).

No caso da linhagem não permissiva Ld652Y ocorreu um retardo de $12 \mathrm{~h}$ na primeira detecção de promotores imediatamente precoces prAgIE1 e prAgGP64 e 17 h no caso dos tardios prAgVP39 e prAgP6.9 que apesar de ativos não foram hiperexpressos. Além disto, os promotores $A g L E F 1$ e $A g P O L H$ não foram ativados. É interessante observar que o promotor LEF1 não foi ativado pois este elemento controla uma proteína associada à replicação do DNA viral, o que pode estar relacionado com as observações associadas à lenta replicação e baixa quantidade de progênie infectiva gerada por esta célula. Como este promotor possui uma expressão fraca nas demais linhagens também é possível que a expressão seja fraca demais para gerar valores de luminescência acima do nível basal de detecção. Como ocorreu expressão dos promotores com elementos tardios VP39 e P6.9 e também ocorre a replicação viral intracelular como medida por qPCR, parece ser mais provável que a expressão de LEF1 ocorre em momentos precoces mas é 
fraca demais para ser detectada. A eventual ativação dos promotores tardios e acúmulo a níveis relativamente altos (equivalentes a Sf9) indicam que não há um impedimento da transcrição dos genes necessários à formação dos BVs, o que é contrário à observação de que esta linhagem não produz este fenótipo (conforme observado na quantificação de DNA extracelular e também reportado por Castro et al, 2006). Isto é consistente com estudos de infectividade do baculovírus AcMNPV que reforçam estas conclusões, considerando níveis relativos inferiores de expressão global em casos em que ocorre replicação viral em conjunto com a expressão limitada de alguns promotores tardios e bloqueio total da expressão dos promotores muito tardios (Morris \& Miller, 1992; Iwanaga et al,2004). Este tema será resgatado na seção 4.4, que terá como foco a comparação entre as infecções de $A c \mathrm{MNPV}$ e $A g \mathrm{MNPV}$.

Esta tese apresenta a primeira descrição da infecção do $A g \mathrm{MNPV}$ na linhagem Chch. Esta linhagem recentemente isolada, tem como uso direto o cultivo e estudo dos Alfabaculovírus grupo II TniSNPV e ChchSNPV (Xu et al., 2010). Esta linhagem entra em apoptose durante a infecção com o baculovírus $A g \mathrm{MNPV}$ assim como ocorre com o baculovírus $A c \mathrm{MNPV}$, ambos Alfabaculovírus do grupo I. A apoptose induzida pelo $A g$ MNPV pode ser observada por microscopia de luz a partir de 12 h p.i.. Até 96 h p.i. praticamente todas as células já morreram por apoptose ou estão em processo (Figura 11, setas azuis). Isto é interessante pois este vírus possui um gene antiapoptótico (iap3) já confirmado como funcional no bloqueio da via das caspases e essencial para a infecção bem sucedida de células permissivas (Carpes et al, 2005). O AgMNPV não possui o outro gene anti-apoptótico presente em $A c \mathrm{MNPV}$, chamado de $p 35$, que foi provado como essencial para evitar a apoptose em células permissivas Sf21 (Clem \& Miller, 1993). A incapacidade do $A g \mathrm{MNPV}$ em inibir por completo a apoptose em Chch é especialmente interessante, em conjunto as observações da infecção por $A c \mathrm{MNPV}$ nesta linhagem, por 
demonstrar que o arsenal de controle celular dos Alfabaculovírus grupo I é exclusivo a este grupo filogenético e é distinto dos elementos encontrados nos Alfabaculovírus do grupo II.

Os genes iap3 e p35 inibem a apoptose afetando diferentes elementos da via das caspases (Clem, 2007). Como observado no perfil de infecção do AgMNPV. O gene iap3 é capaz de inibir parcialmente a apoptose pois os níveis de expressão tardia são consideravelmente altos em relação aos perfis em células permissivas e muito superiores aos observados nas infecções com os $A c \mathrm{MNPV}$ recombinantes (seção 4.4). A expressão na fase precoce ocorreu normalmente, com rápida ativação dos promotores precoces e subsequente ativação dos promotores tardios de forma atrasada, iniciando em 12 h p.i.. Esta linhagem apresentou rápida ativação de prAgIE1 e prAgGP64 (dentro de 2 h p.i.) mas um atraso considerável para o promotor $A g L E F 1\left(\mathrm{~T}_{\text {in }}=17 \mathrm{~h}\right)$, que manteve níveis muito próximo a linhage de base, ao longo da infecção indicando uma expressão comprometida neste tipo celular. As curvas de expressão também apresentaram atrasos para atingir o pico de expressão em relação às linhagens permissivas (Tabela 3) o que implica em reduzida habilidade de transativação da transcrição gênica.

A linhagem Chch apresentou um perfil muito similar ao de Sf9 (Figuras 9 e 10). Todos os promotores foram ativados em sequência como as demais células mas os promotores tardios não apresentaram uma expressão acima da obtida com os promotores precoces. Estes atrasos e a fraca expressão de pr $A g L E F 1$ podem estar associados a apoptose que o vírus induz nesta linhagem celular. A ativação dos promotores tardios, e em especial o promotor muito tardio prAgPOLH, também são observações interessantes pois a expectativa era que se todas as células infectadas iniciam a apoptose logo após a replicação (a partir de 6 h p.i.), a expressão dos promotores tardios e muito tardios estariam comprometidas. É importante ressaltar que prAgPOLH não foi expresso em 
níveis superiores ao dos promotores precoces, que é um marco identificador de uma infecção totalmente permissiva. Os dados de replicação intracelular demonstraram que a replicação viral inicia a partir de 12 h p.i., perfeitamente de acordo com o início da expressão tardia. A alta expressão dos promotores tardios vai em direta oposição à observação que não são formadas partículas virais extracelulares a partir desta infecção.

A linhagem não permissiva Bm5 apenas ativou fracamente os promotores $A g I E 1$ e $A g G P 64$ durante as primeiras 24 h p.i.. Após este momento o sinal caiu gradualmente e oscilou próximo ao valor de background 20 RLU. A linhagem Bm5 apenas ativou os prAgIE1 e prAgGP64, o que é consistente com as observações de infecção abortiva (Castro et al, 1999, 2006) sem produção dos fenótipos de infecção. Observações microscópicas feitas para esta tese a partir da infecção de $A g \mathrm{MNPV}$ às 72 h p.i. não confirmou a formação de corpos apoptóticos ou células em apoptose tardia. É possível que o fenômeno ocorrido em Bm5 esteja mais relacionado com um bloqueio da tradução como observado em Ld652Y infectado com AcMNPV (Thiem et al., 1996), que também está indiretamente associado à inibição da apoptose (Thiem \& Chejanovsky, 2004). Efeitos citopáticos associados a necrose foram observados por microscopia de luz (Figura 11, seta vermelha). Os dois promotores em questão são considerados como imediatamente precoces e portanto capazes de serem transcritos pela RNA pol II do hospedeiro sem a necessidade de transativação nestes momentos. Como nenhuma replicação viral nem expressão dos promotores tardios foram observadas na linhagem Bm5 é possível argumentar que existe nesta célula um mecanismo de defesa capaz de inibir a expressão gênica ainda na fase precoce, de forma a não serem formados os complexos de replicação e transcrição tardia, assim a célula Bm5 é capaz de efetivamente inibir a infecção viral. Outra hipótese seria que o $A g \mathrm{MNPV}$ é equivalente ao $A c \mathrm{MNPV}$, que após receber o gene helicase, que é um componente essencial do complexo de 
replicação do DNA viral, do vírus Bombyx mori NPV torna-se infectivo à célula BmN (também derivada de B. mori como Bm5). Desta forma, existe uma incompatibilidade do complexo de replicação do DNA viral de $A c \mathrm{MNPV}$ durante a infecção deste em células Bm5 e BmN. A hipótese de que o AgMNPV possui uma helicase incompatível com a célula Bm5 poderá ser testada construindo um $A g \mathrm{MNPV}$ recombinante contendo helicase de $B m \mathrm{NPV}$, o que iria efetivamente ativar a expressão dos promotores tardios.

A figura 12 resume a infectividade de $A g \mathrm{MNPV}$ nas linhagens celulares testadas, além de apontar os eventos dentro da infecção celular e o progresso da infecção viral, com base nos dados desta tese.

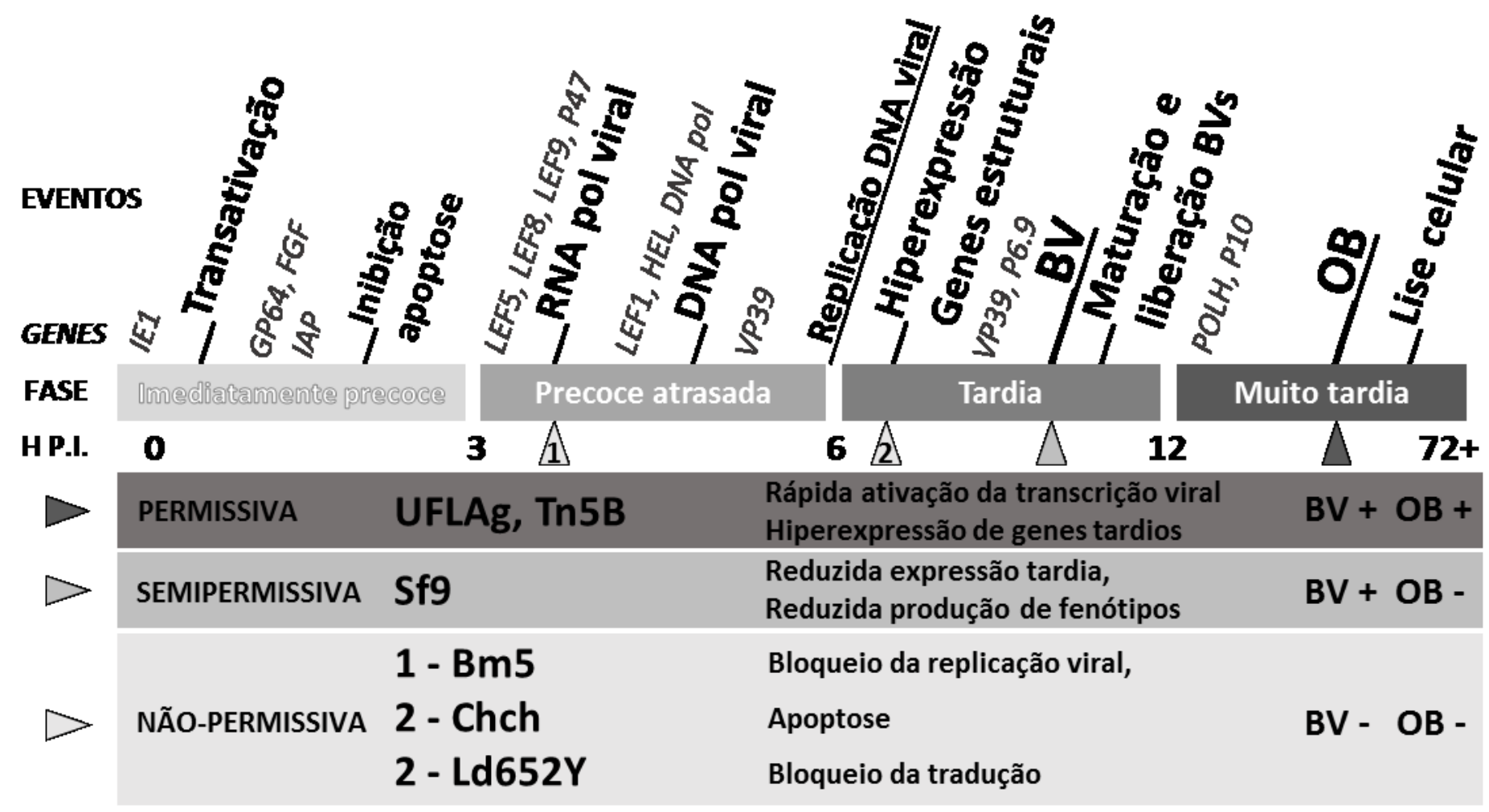

Figura 12: Diagrama descrevendo os eventos gerados pela infecção viral e os genes responsáveis ou associados a cada evento, estes estão dispostos em uma série temporal dividida pelas fases da infecção viral. A permissividade, o progresso da infecção e as características principais estão descritas.

Estas distinções entre os perfis de atividade dos promotores nas linhagens celulares testadas demonstram diversos graus de permissividade à infecção de $A g \mathrm{MNPV}$.

Desde células totalmente permissivas com rápido progresso da infecção, expressão gênica 
e acúmulo de elementos virais na célula; células semipermissivas com rápido início da infecção, mas limitada expressão dos promotores tardios; e células não-permissivas com

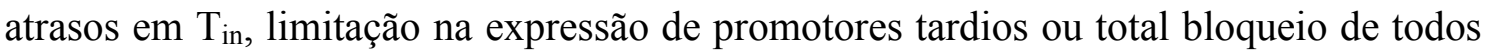
promotores salvo os com atividade imediatamente precoce.

\subsubsection{A replicação viral e maturação de partículas virais do baculovírus $\operatorname{AgMNPV}$ em diferentes linhagens celulares}

A replicação do DNA viral, a encapsidação deste em capsídeos e subsequente liberação do capsídeo para fora da célula, completando a maturação desta partícula na forma do fenótipo BV, são dois fenômenos importantes na biologia da infecção por baculovírus. O início da replicação do DNA viral é considerada como marco que inicia o momento tardio da infecção viral, sendo que todos eventos que precedem este são considerados como da fase precoce. Além disso, a detecção do vírus extracelular indica que a expressão dos genes tardios estruturais atingiu níveis suficientes para iniciar o processo de encapsidação no núcleo e migração das partículas formadas para o citoplasma e membrana celular até saírem da célula. Desta forma, o objetivo destes experimentos foi determinar a dinâmica da replicação viral do $A g \mathrm{MNPV}$ (Figura 13) e a maturação dos vírions como BVs para complementar os dados de expressão gênica.

A replicação viral intracelular na primeira hora de infecção apresentou um valor comum entre as diferentes linhagens celulares testadas (teste t, $p>0.01$ ), o que é esperado pois os experimentos foram feitos com o mesmo número de células e MOI. Entre 3 e $6 \mathrm{~h}$ p.i. não existe diferença significativa entre as médias de concentração de DNA viral entre todas as linhagens (teste t, $\mathrm{p}>0.01$ ). Em 12 h p.i. a concentração de DNA viral em UFLAg e Tn5B aumenta 10 vezes em relação ao momento 6 h p.i., enquanto as demais linhagens ainda mantêm os valores de 6 h p.i. Entre 12 e 24 h p.i. ocorre mais um aumento na concentração de DNA viral em 10 vezes nas linhagens UFLAg e Tn5B. A replicação em 
Sf9, Ld652Y e Chch torna-se evidente entre 12 e 24 h p.i. No momento 72 h p.i. todas as linhagens, exceto $\mathrm{Bm} 5$, apresentaram valores próximos a $10^{6}$ cópias de DNA viral / 10 ng de DNA total (teste $\mathrm{t}, \mathrm{p}>0.001$ ). A linhagem $\mathrm{Bm} 5$ apresentou os menores valores às 72 h p.i., média e $5 \times 10^{4}$ cópias de DNA viral / 10 ng de DNA total, com pouca diferença entre a concentração em 6 h p.i. (teste t, $p=0.0435$ ). Nesta linhagem, é importante notar que os níveis não reduziram, o que indica que mesmo sem ocorrer replicação, o DNA viral permanece dentro da célula e não é degradado.

De forma resumida, é possível afirmar que as linhagens permissivas e semipermissivas à infecção por $A g \mathrm{MNPV}$ são capazes de replicar o DNA viral a partir de $6 \mathrm{~h}$ p.i., sendo a replicação mais rápida nas linhagens permissivas Tn5B e UFLAg, enquanto que a semi-permissiva Sf9, e não-permissivas Ld652Y e Chch apresentaram uma replicação mais lenta. A linhagem Bm5 é completamente não-permissiva à infecção pois não foi observada diferença entre os valores de replicação intracelular obtidos ao longo do tempo.

A quantificação do DNA em BVs revela que em todas linhagens celulares produtivas, ocorrem aumentos de concentração de DNA extracelular apenas a partir de $12 \mathrm{~h}$ p.i.. Às $24 \mathrm{~h}$ p.i. observa-se que as linhagens Tn5B e UFLAg aumentam em 20 vezes a partir do nível basal, enquanto a linhagem Sf9 apresentou um aumento reduzido (não significativo, teste $\mathrm{t}, \mathrm{p}=0.014$ em comparação à $12 \mathrm{~h}$ p.i.). Ainda neste momento, as linhagens Ld652Y, Chch e Bm5 não saíram do nível basal. Às 48 h p.i. observa-se o contínuo aumento de $1 \log$ de magnitude nas linhagens Tn5B e UFLAg. A linhagem Sf9 tem um aumento drástico (40 vezes) entre 24 e 48 h p.i. enquanto a linhagem Ld652Y apresentou um pequeno aumento (não significativo, teste t, $24 \times 48$ h p.i., p = 0.22). As linhagens Bm5 e Chch manteram o nível basal de DNA viral extracelular ao longo das 48 $\mathrm{h}$ de experimento. 
É importante notar que o intervalo entre início da replicação e início da formação de BVs (primeira deteç̧ão) é menor nas linhagens permissivas Tn5B e UFLAg ( 9 a 24 h) do que nas linhagens semipermissiva Sf9 e não-permissiva Ld652Y (24 a 48 h). Estes intervalos correlacionam perfeitamente com o intenso aumento da expressão tardia a partir dos promotores de genes estruturais do $A g \mathrm{MNPV}$ no mesmo período, como discutido na seção 4.1 . 
A

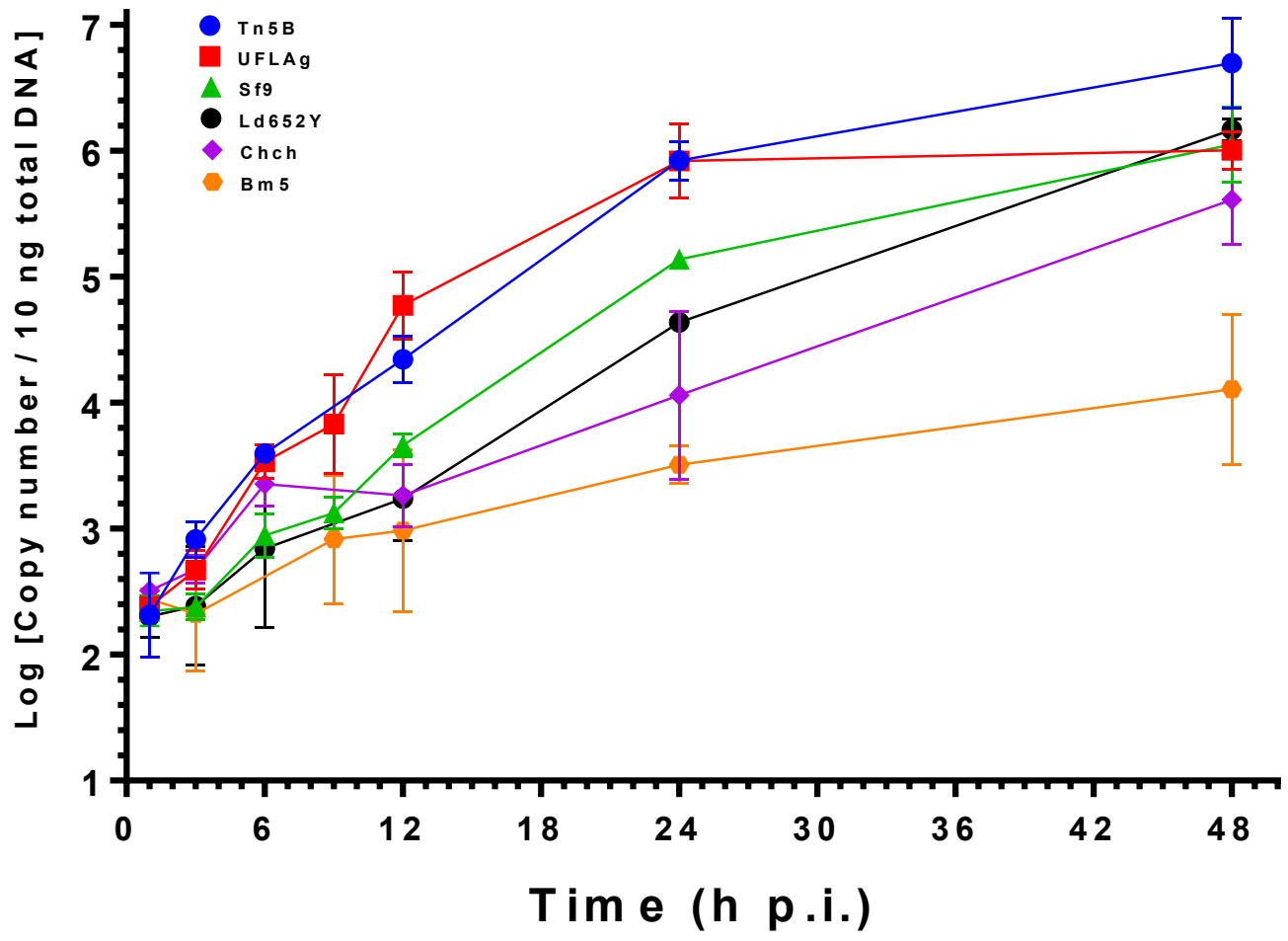

B

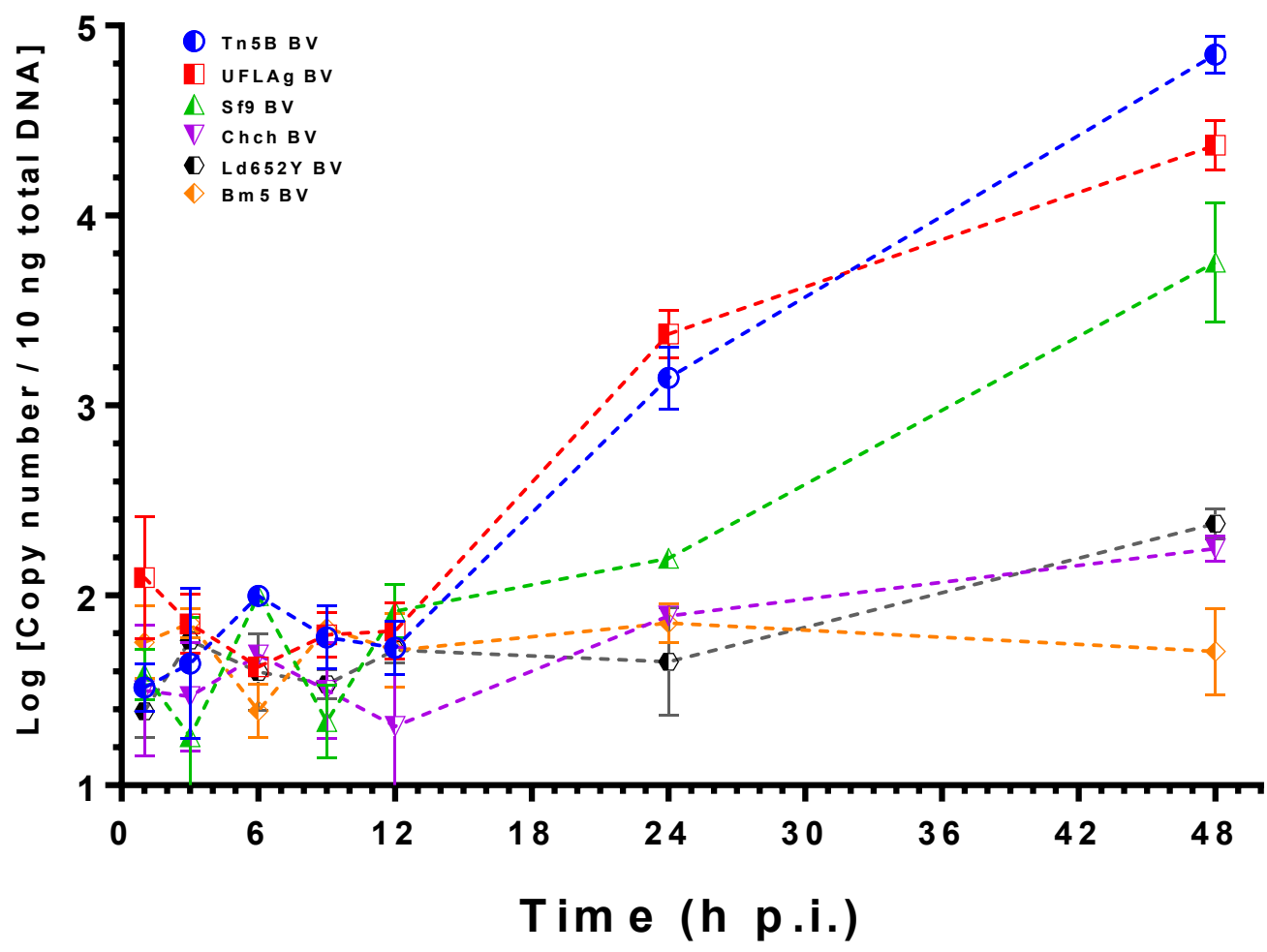

Figura 13: Quantificação do DNA viral intracelular e extracelular por qPCR, durante a infecção de células de inseto pelo baculovírus AgMNPV. Os dados foram apresentados em número de cópias por 10 ng de DNA total em cada reação. 


\subsection{O bloqueio da replicação viral e o efeito sobre a atividade dos promotores virais}

A importância de utilizar um inibidor de replicação do DNA é que este revela quais promotores são dependentes da replicação viral (e em paralelo dependentes da RNA pol viral) para serem ativados, assim distinguindo claramente quais promotores são transcritos pela RNA pol II da célula hospedeira e quais dependem da RNA pol viral. O resultado destes ensaios estão dispostos na figura 14 e tabela 4. Afidicolina já foi utilizada previamente nos estudos iniciais da infecção celular (Rice \& Miller, 1986) e a dose inibitória $\left(\mathrm{IC}_{50}=0.2 \mu \mathrm{M}\right)$ da replicação viral já foi determinada experimentalmente para a linhagem Sf21 (Thumbi et al, 2007). Neste trabalho utilizamos uma dose consideravelmente mais alta de $5 \mu \mathrm{M}$ para tentar garantir a inibição total da replicação e não foram observados efeitos citopáticos nas células contendo afidicolina nesta dose até 5 d p.i. por inspeção visual em microscopia de luz. 

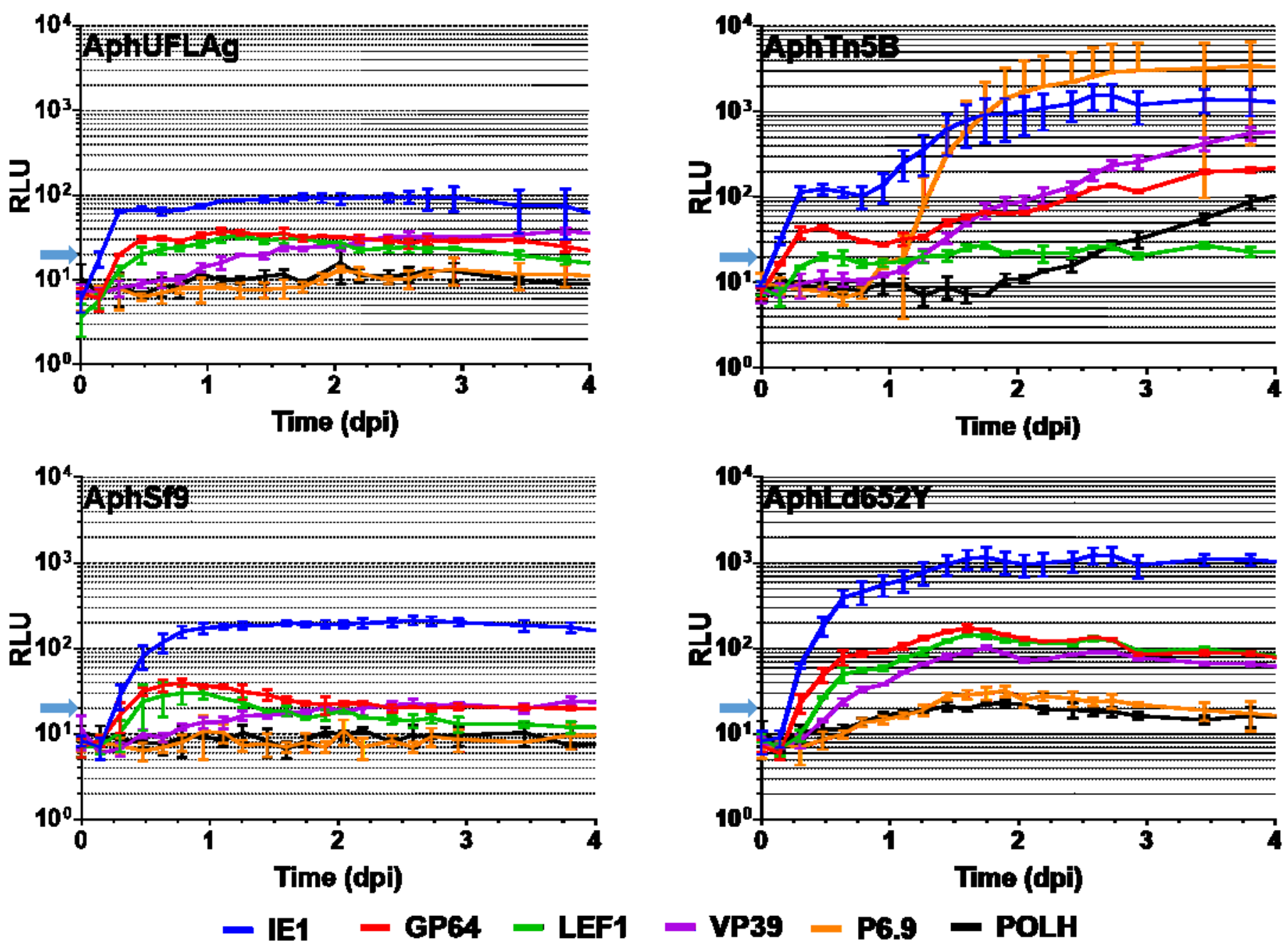

Figura 14: Ensaios de medição contínua de luminescência nas linhagens UFLAg, Tn5B, Sf9 e Ld652Y tratadas com o inibidor de replicação de DNA e infectadas com os baculovírus AgMNPV recombinantes em MOI 10. Os intervalos apresentados são de $3 \mathrm{~h}$ entre medições. As setas azuis no eixo $\mathrm{Y}$ indicam o nível basal de luminescência (20 RLU). As medições são apresentadas como média de triplicatas e barras de erro representam o desvio padrão.

Tabela 4: Tempo de primeira detecção $\left(T_{\text {in }}\right)$ do sinal de luminescência (hh:mm), ensaio com células tratadas com Afidicolina.

\begin{tabular}{cccccccc}
\hline Linhagem & \multicolumn{6}{c}{ Vírus } \\
\hline & IE1FLUC & GP64FLUC & LEF1FLUC & VP39FLUC & P6.9FLUC & POLHFLUC \\
& Média & Média & Média & Média & Média & Média \\
\hline UFLAg & $3: 18$ & $6: 11$ & $8: 17$ & $27: 14$ & - & - \\
Tn5B & $2: 48$ & $3: 21$ & $7: 08$ & $28: 21$ & $27: 06$ & $57: 44$ \\
Sf9 & $6: 13$ & $6: 48$ & $9: 56$ & $28: 13$ & - & - \\
Ld652Y & $4: 13$ & $5: 54$ & $8: 54$ & $12: 12$ & $23: 29$ & $14: 32$ \\
\hline
\end{tabular}


As classificações da fase da infecção dos promotores de $A g \mathrm{MNPV}$ expostas previamente, baseadas primariamente em $\mathrm{T}_{\mathrm{in}}$, foram confirmadas por estes experimentos com os recombinantes $A g \mathrm{MNPV}$, os promotores pr $A g I E 1, \operatorname{pr} A g$ GP64, pr $A g L E F 1$ e $\operatorname{pr} A g$ VP39 são ativados em momentos precoces da infecção pela RNA pol II do hospedeiro em todas as linhagens testadas, com rápida ativação em UFLAg e Tn5B. Uma característica observada foi que prAgIE1 antecedeu os demais ( $\mathrm{T}_{\text {in }} 3 \mathrm{~h}$ p.i. em UFLAg e Tn5B e 6 h p.i. em Sf9) e produziu os maiores níveis de expressão, que foram 1 log de magnitude inferiores aos obtidos sem afidicolina. Os promotores pr $A g$ GP64 e pr $A g L E F 1$ formaram curvas sem diferenças significativas (two-way ANOVA não significante entre todos pontos de medição). O promotor VP39 apresentou um atraso em $\mathrm{T}_{\text {in }}$ de $24 \mathrm{~h}$ e fraca expressão, pouco acima do nível mínimo. Os promotores tardios P6.9 e POLH não foram ativados durante a infecção de UFLAg e Sf9, e isto confirma a observação referente à ausência de motivos de transcrição precoces (ativados pela RNA pol II do hospedeiro) e presença apenas de motivos de transcrição tardios (ativados pela RNA pol viral que por sua vez é dependente da replicação viral).

Uma observação comum a todas células testadas neste ensaio foi a estabilidade dos sinais de luminescência depois de ativados por 4 dias de infecção, isto é indicativo de que o DNA viral uma vez inserido nas células de inseto é mantido de forma estável e é transcrito no núcleo da célula durante todo este período.

Na dose de afidicolina utilizada, a linhagem Tn5B foi capaz de reverter o bloqueio de replicação após 24 h p.i., ativando prAgP6.9 e prAgPOLH. A reversibilidade da inibição da replicação em Tn5B após 24 h p.i. apesar de indesejada, não é uma grande surpresa pois a atuação deste composto é reversível e os estudos de inibição foram estimados apenas para Sf21 (Thumbi et al, 2007). É interessante observar que após a reversão da inibição, o nível de expressão de pr $A g I E 1$ subiu a níveis considerados normais 
$\left(10^{3}\right.$ RLU), demonstrando que a replicação viral é capaz de aumentar a expressão gênica dos promotores precoces, uma observação inédita nos estudos de expressão dos baculovírus. Entre os promotores ativados, o elemento prAgIE1 apresentou expressão consideravelmente maior que os demais ( 1 log de magnitude), indicando que existem diferenças de mecanismos entre prAgIE1 e prAgGP64, sendo prAgIE1 mais eficaz em recrutar a RNA pol II do hospedeiro. Outra possibilidade é que a transativação da proteína IE1 sobre os demais promotores precoces não é eficiente. De qualquer forma, ambos foram os primeiros a serem ativados e são distintos de pr $A g L E F 1$ que inicia 2 a 3 h após estes, confirmando a distinção entre as classes imediatamente precoces e precoces atrasados.

A linhagem LD652Y apresentou um perfil de expressão distinto ao obtido com o ensaio na ausência de afidicolina. Neste experimento a célula não retardou $T_{\text {in }}$ dos promotores drasticamente, que apresentaram tempos muito próximos aos das demais células tratadas com afidicolina e das permissivas não tratadas, todos com $\mathrm{T}_{\text {in }}$ dentro das primeiras 6 h p.i.. Os elementos prAgP6.9 e prAgPOLH tiveram uma expressão ligeiramente acima do nível basal entre 14 e 24 h p.i. que retornou a valores basais.

Na presença de afidicolina, foi possível observar em todas linhagens que apenas os promotores precoces foram ativados após a infecção, incluindo prAgLEF1 e prAgVP39, considerados precoces atrasados e passíveis de transativação pela proteína IE1. Como os genes que compõem a RNA pol viral (lef4, lef8, lef9 e $p 47)$ de AcMNPV são expressos em momentos precoces da infecção (Chen et al, 2013), é bem provável que nestes experimentos a RNA pol viral foi expressa. No entanto não detectamos atividade nos promotores tardios indicando que mesmo expressa, a RNA pol viral é dependente da replicação viral para iniciar a expressão dos genes tardios. Outra possibilidade é que os genes tardios foram expressos em quantidades muito reduzidas, o que produz 
luminescência abaixo do limite estabelecido. Apenas após avaliar a transcrição dos genes e expressão das subunidades da RNA pol viral, individualmente, na condição de inibição da replicação de DNA será possível afirmar conclusivamente que existe algum mecanismo de bloqueio da transcrição tardia pela RNA pol viral dependente da replicação do DNA viral.

O perfil de expressão dos promotores de $A g \mathrm{MNPV}$ em células tratadas com afidicolina foram muito similares a infecção da célula não-permissiva Bm5. Em ambos os casos apenas os promotores precoces foram ativados e os níveis de expressão atingem níveis baixos. Esta correlação entre os perfis de expressão, como um todo, de células normalmente infectadas e as mesmas com replicação viral inibida reitera a hipótese que durante a infecção da linhagem Bm5 ocorre a inibição da replicação do DNA viral no núcleo e é a ausência de replicação que inibe a expressão dos promotores e genes tardios.

Estes perfis de expressão com a replicação do DNA viral inibida também contrastam com o das células não-permissivas Ld652Y e Chch, assim denominadas por não produzirem os fenótipos virais apesar de ocorrer a replicação do DNA viral e expressão de promotores tardios. Nestes casos, a defesa celular ocorre em momentos tardios e a inibição da formação de vírus maduro ocorre por mecanismos de defesa como uma limitação de síntese de proteínas em Ld652Y e apoptose em Chch.

\subsection{Efeito da multiplicidade de infecção e número de células na expressão dos promotores virais durante a infecção de células de inseto por $\operatorname{AgMNPV}$ recombinantes}

Os parâmetros chave no desenho experimental e otimização da expressão gênica utilizando baculovírus recombinantes como sistemas de expressão de proteínas heterólogas em células de inseto cultivadas in vitro são a quantidade de células, as condições das células e a multiplicidade de infecção (Elias et al em Murhammer, 2007). 
Estes são parâmetros correlatos que geram limitações na expressão gênica durante a infecção celular. Assume-se que quanto maior o número de células infectadas maior é a produtividade, no entanto um número excessivamente alto de células afeta a disponibilidade de nutrientes, o que por sua vez reduz a produtividade (Huynh et al, 2013; Power et al, 1999). Outro ponto é que uma infecção síncrona, isto é, todas as células infectadas simultaneamente, deve gerar uma produção maior em menor tempo, pois as células irão se beneficiar de um meio ainda rico. Para garantir uma infecção síncrona é necessária a utilização de MOI acima de 1, sendo que a MOI 10 (10 vírus por célula) oferece teoricamente $90 \%$ de confiança que todas as células serão infectadas (O'Reilly et $a l, 1992)$. O aumento do número de células requer um inóculo ainda mais concentrado, o que envolve procedimentos extras de enriquecimento do inóculo viral quando trabalhamos com volumes muito altos ou um grande número de recombinantes. Em conjunto, existe uma configuração ótima destes dois parâmetros que permite a maximização da produtividade do sistema de expressão com o mínimo de recursos e tempo (Zeiser et al, 2000; O`Reilly et al, 1992). Utilizando variações de concentração do inóculo viral e o número de células durante a infecção celular com os baculovírus recombinantes vAgIE1FLUC ou vAgGP64FLUC, vAgVP39FLUC, vAgP69FLUC e vAgPOLHFLUC no método de avaliação de luminescência em tempo real foi possível testar o efeito destes parâmetros sobre a expressão gênica de promotores representantes de cada fase da infecção viral. Em relação à MOI foram realizados experimentos com as linhagens suscetíveis UFLAg e Tn5B e a linhagem semi-permissiva Sf9. Os ensaios que testam o efeito do número de células focaram na linhagem Tn5B.

O padrão comum do efeito da MOI sobre todas as células e promotores foi um retardo drástico de $\mathrm{T}_{\text {in }}$ em MOIs abaixo de 1. A variação de MOI resultou em um efeito marginal sobre o valor máximo de luminescência em Tn5B e Sf9 (Figuras 16 e 17, gráfico 
B, linhas de regressão com inclinação positiva) e efeito negligente em UFLAg (Figura 15, gráfico B, linhas de regressão praticamente horizontais).

Em UFLAg e Tn5B a MOI 0.001 (Figuras 15 e 16) as curvas de expressão são iniciadas apenas após 24 h p.i. e eventualmente atingem níveis considerados altos de luminescência (> 300 RLU) indicando uma rápida proliferação da infecção celular. A linhagem semipermissiva $\mathrm{Sf} 9$ resultou em atrasos maiores em $T_{i n}, T_{p i}$ e $V_{\max }$ menores (Figura $17 \mathrm{Sf} 9$, gráficos $\mathrm{A}, \mathrm{B}$ e $\mathrm{C}$ e tabela inclusa), indicando uma reduzida habilidade desta linhagem em proliferar a infecção secundária.

Acima da MOI 1 os valores de $T_{\text {in }}$ são idênticos, característico à uma infecção síncrona inicial de todas as células, indicando um limite mínimo de tempo que reflete a disponibilidade de proteínas virais recém sintetizadas e proteínas do hospedeiro responsáveis pela transcrição em que cada promotor pode ser transcrito, mesmo com uma saturação de DNA viral dentro da célula (figuras 15, 16 e 17, gráfico A de todas as células). Este limite mínimo de $\mathrm{T}_{\text {in }}$ de cada promotor ocorre devido a produção simultânea de FLUC em um grande número de células, fazendo com que a luminescência suba acima do nível basal imediatamente após os promotores serem ativados. A infecção nãosíncrona $(\mathrm{MOI}<1)$ apresenta uma dinâmica de atrasos na detecção inicial devido aos limites de detecção do equipamento. Em baixa MOI, poucas células são infectadas inicialmente e a produção de FLUC não é suficiente para ser detectada. O atraso na detecção resulta do atraso na proliferação da infecção secundária às demais células, que é ainda maior em uma célula semipermissiva como Sf9 abaixo de MOI 1, em termos de produtividade na expressão $\left(\mathrm{V}_{\max }\right.$ reduzidos drasticamente), possivelmente relacionado à reduzida habilidade de expressão dos genes tardios e formação de BVs discutido anteriormente. 
A configuração de MOI 10 foi a mais eficiente com menores valores de $T_{\text {in }}$ e maiores valores de $V_{\max }$. Esta configuração é considerada padrão em ensaios de expressão de proteínas (O’Reilly et al, 1992; Aucoin et al, Elias et al em Murhammer, 2007). É difícil explicar as razões da redução de produtividade nas infecções síncronas com MOIs 50 e 100. A presença de múltiplos vírions na infecção primária poderia auxiliar na aceleração da expressão, no entanto, o que foi observado é que a superinfecção tem um efeito deletério sobre a produção total de proteína recombinante.

Um benefício ao escolher o $A c$ MNPV como sistema de expressão de proteínas recombinantes é a disponibilidade dos sistemas de clonagem que facilitam a construção dos baculovírus recombinantes. Existe um sistema comercial de construção de $A c \mathrm{MNPV}$ recombinante com deleção no gene v-cath (BestBac 2.0, Expression Systems), que codifica uma protease que reduz a produtividade na expressão de proteínas (Slack et al, 1995) e afirma ser mais produtivo que o sistema BAC-to-BAC ou similares que utilizam o genoma do AcMNPV apenas com modificações no locus do gene polh. Os genes $v$ cath e quit estão ausentes naturalmente no genoma de $A g M N P V$ e portanto este vírus é uma alternativa interessante e potencialmente mais eficiente que os sistemas de expressão baseados em $A c \mathrm{MNPV}$. 


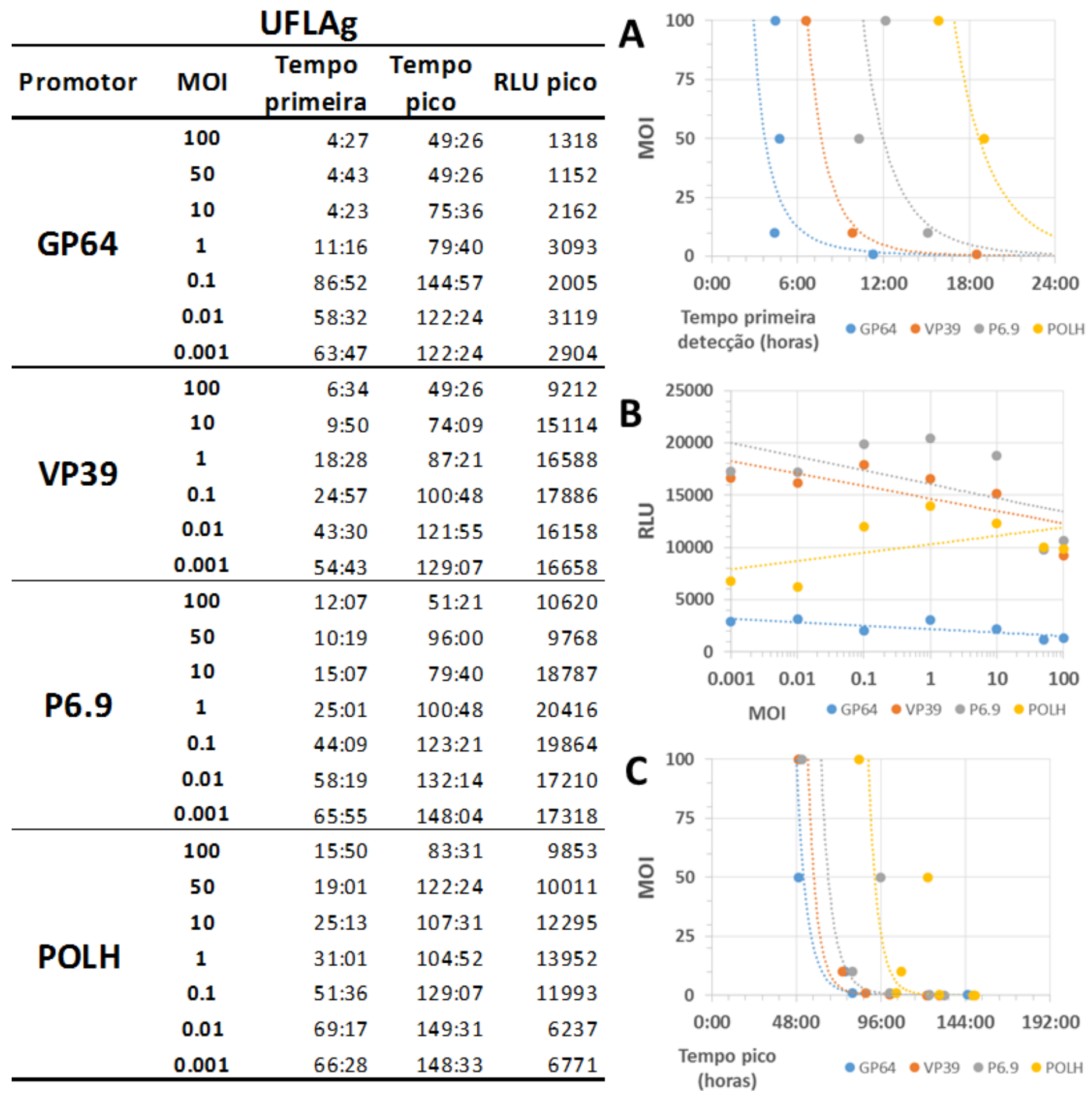

Figura 15: Ensaios de medição contínua de luminescência na linhagem UFLAg infectadas com os baculovírus AgMNPV recombinantes vAgGP64FLUC, vAgVP39FLUC, vAgP69FLUC e vAgPOLHFLUC em MOls 100, 50, 10, 5, 1, $0.1,0.01$ e 0.001. A tabelas indica os valores de $T_{i n}, T_{p i}$ e $V_{\max }$ de cada configuração de tratamento. A - Gráfico de correlação entre $T_{\text {in }}$ e MOI. B - Gráfico de correlação entre $V_{\max }$ e MOI. C - Gráfico de correlação entre $T_{p i}$ e $M O I$. Regressão linear dos pontos nos gráficos $A$ e $B$. Regressão logarítmica em $B$. Todas as regressões apresentaram $R^{2}$ $>0.90$. 
$\operatorname{Tn} 5 B$

\begin{tabular}{|c|c|c|c|c|}
\hline Promotor & MOI & $\begin{array}{l}\text { Tempo } \\
\text { primeira }\end{array}$ & $\begin{array}{l}\text { Tempo } \\
\text { pico }\end{array}$ & RLU pico \\
\hline \multirow{7}{*}{ GP64 } & 100 & $0: 35$ & $47: 02$ & 1857 \\
\hline & 50 & $0: 32$ & $49: 26$ & 2740 \\
\hline & 10 & $1: 00$ & 50:09 & 4179 \\
\hline & 1 & $2: 25$ & $75: 36$ & 4094 \\
\hline & 0.1 & $28: 37$ & $113: 31$ & 2966 \\
\hline & 0.01 & $30: 53$ & $115: 26$ & 2340 \\
\hline & 0.001 & $66: 00$ & $142: 48$ & 510 \\
\hline \multirow{7}{*}{ VP39 } & 100 & $2: 49$ & $43: 26$ & 17429 \\
\hline & 50 & $3: 36$ & $46: 19$ & 20403 \\
\hline & 10 & $5: 14$ & $53: 31$ & 24094 \\
\hline & 1 & $8: 38$ & $66: 43$ & 17930 \\
\hline & 0.1 & $26: 28$ & $123: 21$ & 10512 \\
\hline & 0.01 & $31: 40$ & $122: 52$ & 6408 \\
\hline & 0.001 & $47: 02$ & $128: 38$ & 1437 \\
\hline \multirow{7}{*}{ P6.9 } & 100 & $9: 20$ & $49: 26$ & 32486 \\
\hline & 50 & $9: 36$ & $49: 26$ & 40882 \\
\hline & 10 & $10: 19$ & 50:09 & 31781 \\
\hline & 1 & $14: 38$ & $90: 28$ & 25153 \\
\hline & 0.1 & $30: 02$ & $136: 48$ & 15366 \\
\hline & 0.01 & $35: 12$ & $140: 38$ & 8145 \\
\hline & 0.001 & $62: 24$ & $146: 38$ & 488 \\
\hline \multirow{7}{*}{ POLH } & 100 & $13: 04$ & $53: 31$ & 30190 \\
\hline & 50 & $13: 02$ & $53: 31$ & 34626 \\
\hline & 10 & $13: 29$ & $66: 43$ & 39148 \\
\hline & 1 & 18:19 & $87: 21$ & 22555 \\
\hline & 0.1 & $40: 52$ & $140: 09$ & 17841 \\
\hline & 0.01 & $49: 32$ & $148: 33$ & 8834 \\
\hline & 0.001 & $54: 57$ & 149:31 & 4546 \\
\hline
\end{tabular}
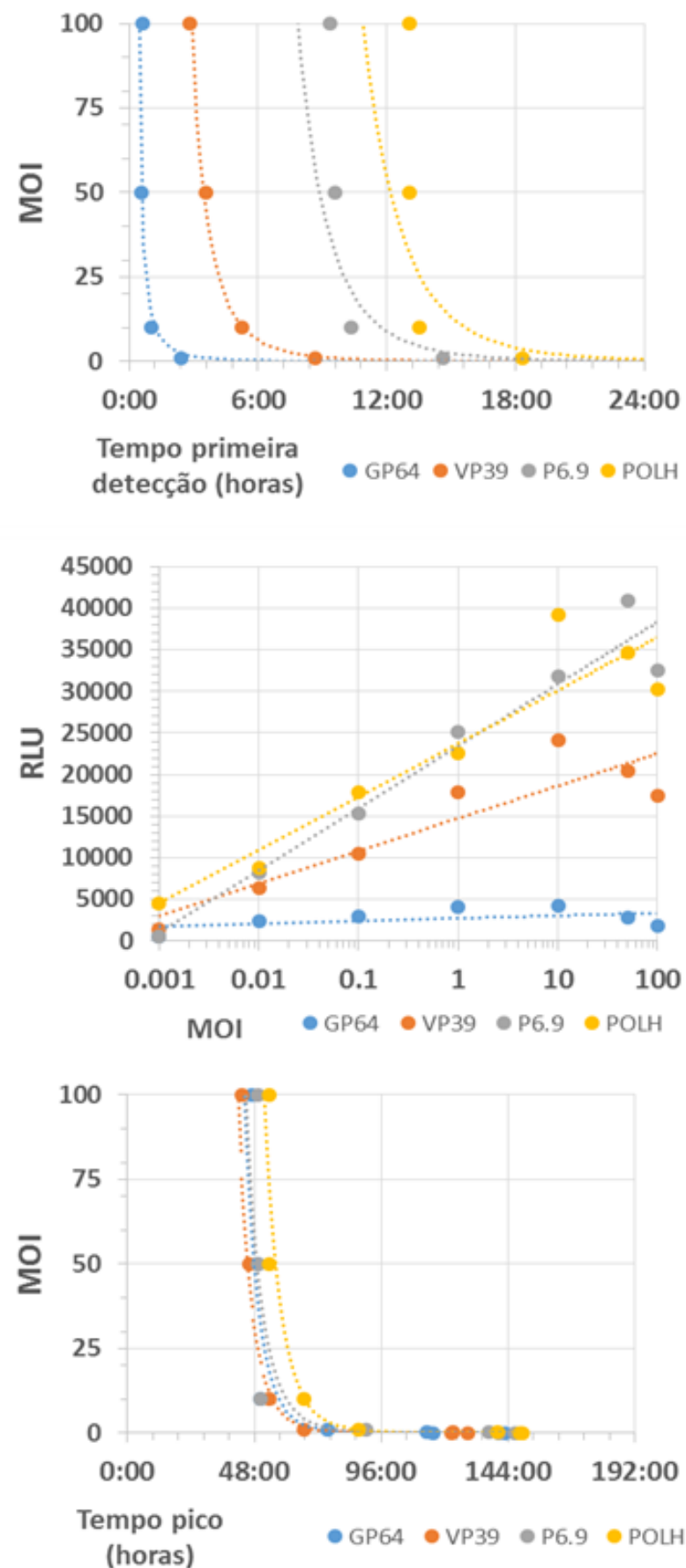

Figura 16: Ensaios de medição contínua de luminescência na linhagem Tn5B infectadas com os baculovírus AgMNPV recombinantes vAgGP64FLUC, vAgVP39FLUC, VAgP69FLUC e vAgPOLHFLUC em MOls 100, 50, 10, 5, 1, 0.1, 0.01 e 0.001. Os intervalos apresentados são de $3 \mathrm{~h}$ entre medições. As tabelas indicam os valores de $T_{\mathrm{in}}, \mathrm{T}_{\mathrm{pi}}$ e $\mathrm{V}_{\max }$ de cada configuração de tratamento. A - Gráfico de correlação entre $T_{\text {in }}$ e MOI. B - Gráfico de correlação entre $V_{\max }$ e MOI. C - Gráfico de correlação entre $\mathrm{T}_{\mathrm{pi}}$ e $\mathrm{MOI}$. Regressão linear dos pontos nos gráficos A e B. Regressão logarítmica em B. Todas as regressões apresentaram $R^{2}>0.90$. 
Sf9

\begin{tabular}{|c|c|c|c|c|}
\hline Promotor & MOI & $\begin{array}{c}\text { Tempo } \\
\text { primeira }\end{array}$ & $\begin{array}{c}\text { Tempo } \\
\text { pico }\end{array}$ & RLU pico \\
\hline \multirow{7}{*}{ GP64 } & 100 & $1: 26$ & $25: 26$ & 5080 \\
\hline & 50 & $1: 34$ & $30: 43$ & 5662 \\
\hline & 10 & $2: 43$ & $36: 43$ & 6559 \\
\hline & 1 & $10: 31$ & $87: 50$ & 5023 \\
\hline & 0.1 & $47: 02$ & $168: 57$ & 973 \\
\hline & 0.01 & $74: 24$ & $168: 28$ & 173 \\
\hline & 0.001 & $90: 18$ & $168: 28$ & 74 \\
\hline \multirow{7}{*}{ VP39 } & 100 & $2: 16$ & $32: 09$ & 23614 \\
\hline & 50 & $2: 13$ & $32: 09$ & 32448 \\
\hline & 10 & $3: 23$ & $34: 19$ & 37187 \\
\hline & 1 & $7: 19$ & $58: 19$ & 29193 \\
\hline & 0.1 & $26: 38$ & $148: 04$ & 3152 \\
\hline & 0.01 & $42: 00$ & 148:04 & 344 \\
\hline & 0.001 & $77: 31$ & $78: 28$ & 26 \\
\hline \multirow{7}{*}{ P6.9 } & 100 & $7: 33$ & $34: 19$ & 43074 \\
\hline & 50 & $8: 39$ & $42: 14$ & 42290 \\
\hline & 10 & $10: 39$ & $65: 02$ & 37788 \\
\hline & 1 & $14: 24$ & $98: 24$ & 17835 \\
\hline & 0.1 & $37: 40$ & $171: 50$ & 1975 \\
\hline & 0.01 & $71: 06$ & $171: 50$ & 179 \\
\hline & 0.001 & $68: 38$ & $125: 31$ & 71 \\
\hline \multirow{7}{*}{ POLH } & 100 & 9:06 & $52: 33$ & 26871 \\
\hline & 50 & 9:09 & $53: 02$ & 34374 \\
\hline & 10 & 9:11 & $53: 31$ & 36035 \\
\hline & 1 & $20: 52$ & $116: 09$ & 14025 \\
\hline & 0.1 & $49: 45$ & $171: 50$ & 1137 \\
\hline & 0.01 & $78: 38$ & $171: 50$ & 135 \\
\hline & 0.001 & $78: 38$ & $168: 28$ & 97 \\
\hline
\end{tabular}
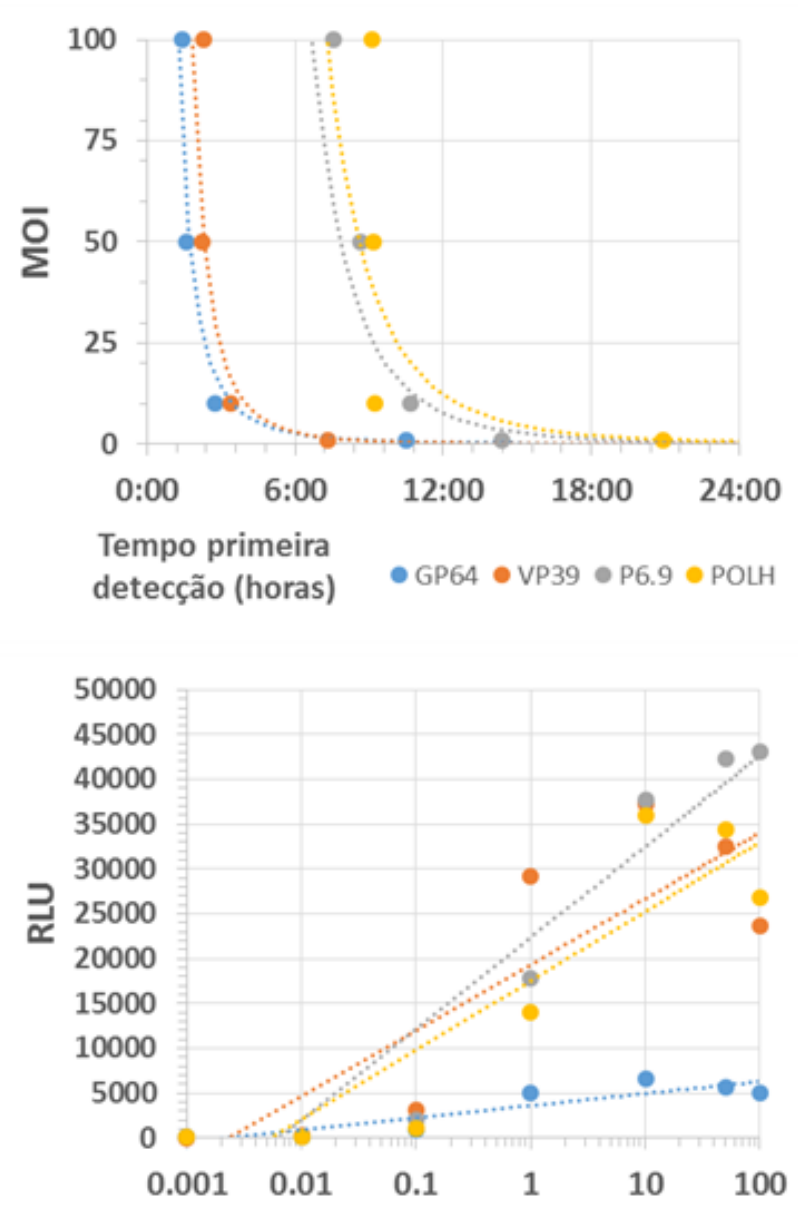

MOI • GP64 • VP39 •P6.9 P POLH

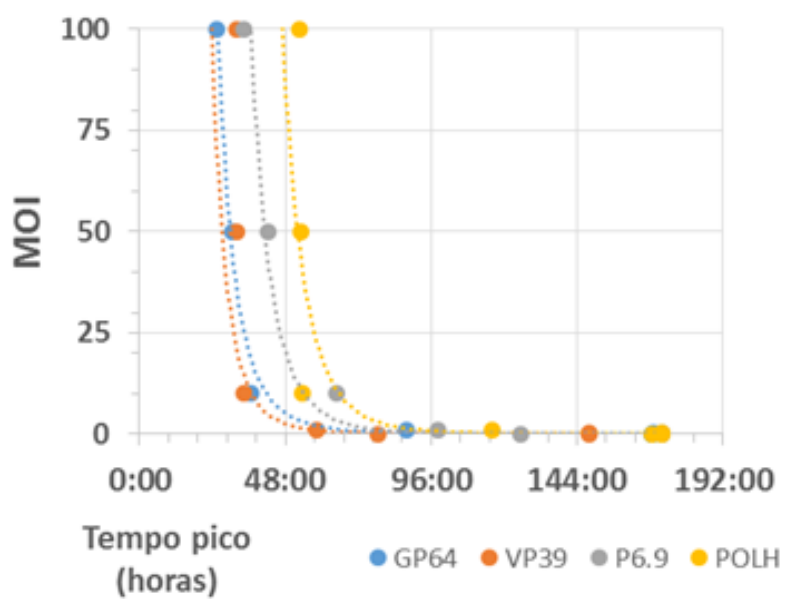

Figura 17: Ensaios de medição contínua de luminescência na linhagem Sf9 infectadas com os baculovírus AgMNPV recombinantes vAgGP64FLUC, vAgVP39FLUC, vAgP69FLUC e vAgPOLHFLUC em MOls 100, 50, 10, 5, 1, $0.1,0.01 \mathrm{e}$ 0.001. Os intervalos apresentados são de $3 \mathrm{~h}$ entre medições. As tabelas indicam os valores de $T_{\text {in, }} T_{\text {pi }}$ e $V_{\max }$ de cada configuração de tratamento. A - Gráfico de correlação entre $\mathrm{T}_{\text {in }}$ e MOI. B - Gráfico de correlação entre $\mathrm{V}_{\max }$ e MOI. C - Gráfico de correlação entre $\mathrm{T}_{\mathrm{pi}}$ e $\mathrm{MOI}$. Regressão linear dos pontos nos gráficos A e B. Regressão logarítmica em B. Todas as regressões apresentaram $R^{2}>0.90$. 
A variação do número de células no momento da infecção teve um efeito sobre os níveis de expressão, geralmente reduzindo Vmax com pequenas alterações em Tin (Figura 18, tabela associada). Este experimento demonstrou que o aumento de número de células infectadas em um poço amplia o sinal de luminescência derivado da infecção síncrona de células pelo $A g \mathrm{MNPV}$.

Também demonstra que a concentração "padrão" de células utilizadas nos ensaios (100\% de confluência, $1 \times 10^{6}$ células / ml) induz o maior sinal possível de luminescência, assumindo o cultivo de células aderentes em placas de 96 poços. $\mathrm{O}$ aumento gradual do número de células até atingir a concentração de confluência do cultivo melhora a intensidade do sinal.

O limite de detecção da expressão por este método depende da presença de pelo menos $2 \times 10^{4}$ células por poço $\left(1 \times 10^{5} / \mathrm{ml}\right)$ infectadas de forma sincronizada e uma forte expressão do promotor, isto é derivado da observação que nesta concentração de células, o elemento pr $A g I E 1$ praticamente não foi capaz de induzir luminescência acima do basal. Esta limitação torna-se extremamente importante em especial na detecção da curva de expressão de pr $A g L E F 1$, com sinais bem fracos mesmo em alta concentração de células. Em confluência de $10 \%$ os promotores tardios apresentaram sinais altos de luminescência com atrasos em $\mathrm{T}_{\text {in }}$ de $8 \mathrm{~h}$ para $\operatorname{pr} A g \mathrm{VP} 39$ e prAgP6.9 e $20 \mathrm{~h}$ para $\operatorname{pr} A g \mathrm{POLH}$. 


\section{Tn5B}

\begin{tabular}{|c|c|c|c|c|}
\hline Promotor & Confluência & $\begin{array}{c}\text { Tempo } \\
\text { primeira } \\
\text { detecção }\end{array}$ & $\begin{array}{c}\text { Tempo } \\
\text { pico }\end{array}$ & RLU pico \\
\hline \multirow{4}{*}{ IE1 } & $100 \%$ & $0: 23$ & $21: 29$ & 488 \\
\hline & $50 \%$ & $0: 27$ & $18: 35$ & 190 \\
\hline & $25 \%$ & $0: 30$ & 19:14 & 101 \\
\hline & $10 \%$ & $1: 51$ & $17: 41$ & 34 \\
\hline \multirow{4}{*}{ VP39 } & $100 \%$ & $3: 19$ & $31: 26$ & 17820 \\
\hline & $50 \%$ & 4:11 & $42: 48$ & 12101 \\
\hline & $25 \%$ & $5: 24$ & 49:51 & 6986 \\
\hline & $10 \%$ & $13: 43$ & $71: 52$ & 688 \\
\hline \multirow{4}{*}{ P6.9 } & $100 \%$ & $5: 15$ & $30: 04$ & 16803 \\
\hline & $50 \%$ & $5: 21$ & $42: 37$ & 10988 \\
\hline & $25 \%$ & $5: 43$ & $50: 04$ & 4516 \\
\hline & $10 \%$ & $15: 28$ & $66: 50$ & 417 \\
\hline \multirow{4}{*}{ POLH } & $100 \%$ & $7: 45$ & $49: 55$ & 19269 \\
\hline & $50 \%$ & $16: 01$ & $58: 23$ & 11430 \\
\hline & $25 \%$ & 22:01 & $71: 30$ & 6209 \\
\hline & $10 \%$ & $31: 48$ & $70: 57$ & 682 \\
\hline
\end{tabular}
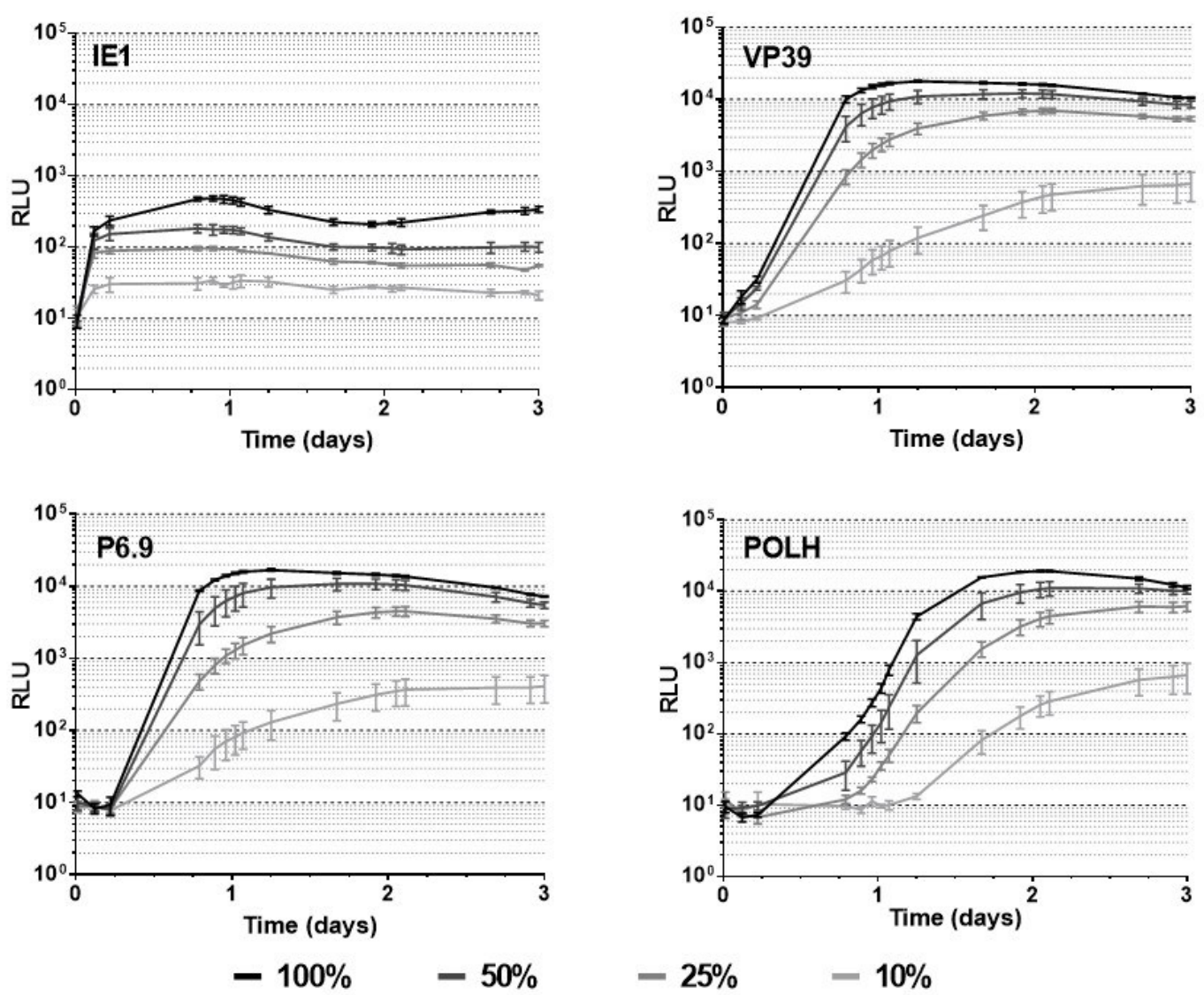

Figura 18: Ensaios de medição contínua de luminescência na linhagem Tn5B infectada com os baculovírus AgMNPV recombinantes VAgIE1FLUC, VAgVP39FLUC, VAgP69FLUC e VAgPOLHFLUC em MOIs 10 com concentrações distintas de células semeadas. Os intervalos apresentados são variáveis entre medições. A tabela indica os valores de $T_{i n}, T_{p i}$ e $V_{\max }$ de cada configuração de tratamento. 
Pela avaliação do efeito MOI, obtivemos alguns resultados relevantes às classificações dos promotores feitas antes em relação aos valores de $T_{i n}, T_{p i}$ e $V_{\max }$ de cada promotor testado. Em termos de expressão máxima de gene repórter, os promotores de $A g \mathrm{MNPV}$ mais produtivos foram os tardios prAgVP39, prAgP6.9 e muito tardio prAgPOLH, nesta ordem. Pela superinfecção em MOIs $>10$ observamos um valor mínimo de $T_{\text {in }}$ e $T_{p i}$, o que nos sugere que as condições utilizadas nos ensaios de permissividade foram ideais e correspondentes à uma infecção síncrona, eliminando a possibilidade de variabilidade inerente a inóculos com erros de titulação e assim reforçando as conclusões feitas anteriormente. De forma similar, a alta confluência utilizada nos ensaios de permissividade também serviram para ampliar ao máximo o sinal de luminescência obtido durante as infecções. Estes experimentos que testaram os parâmetros MOI e confluência durante a infecção de $A g \mathrm{MNPV}$ s foram úteis por revelar alguns dos limites da técnica de medição e configurações experimentais, assim obtendo um reforço na confiança das conclusões em relação a expressão gênica dos baculovírus e às aplicações da própria técnica.

Com base nestas observações de expressão de genes heterólogos a partir das infecções com o AgMNPV, podemos argumentar que a metodologia ótima para expressão gênica seria utilizar linhagens permissivas ao AgMNPV, como UFLAg e Tn5B, 100\% de confluência de células aderentes e uma multiplicidade de infecção entre 1 e 10 para garantir infecção síncrona no início da infecção. Utilizando promotores tardios como prAgVP39 ou prAgP6.9 e coletando o material em 48 h p.i. obtêm-se a maior abundância da proteína heteróloga de interesse.

2.4. O programa de expressão gênica do baculovírus $A c$ MNPV durante a infecção de células de inseto derivadas de Lepidoptera e a atividade de promotores heterólogos derivados de $\mathrm{AgMNPV}$ 
Neste trabalho, foram construídos baculovírus recombinantes $A c \mathrm{MNPV}$ contendo os mesmos promotores do $A g \mathrm{MNPV}$ estudados nas seções anteriores e os promotores de genes equivalentes contidos no genoma do $A c \mathrm{MNPV}$. Para construir os recombinantes foi utilizado o sistema BAC-to-BAC (Invitrogen) de geração de baculovírus modificados por transposição sítio-específica em células E. coli DH10BAC. Este sistema contém um genoma circular e modificado do AcMNPV que é mantido na bactéria como um replicon de baixa cópia além de um plasmídeo helper contendo os genes da transposase $\operatorname{Tn} 7$. Para realizar a transposição, é necessário transformar em DH10BAC um plasmídeo de transferência pFASTBAC-T1 (Invitrogen) ou derivados, contendo os elementos de interesse, no caso, os promotores isolados a montante do gene repórter fluc.

$\mathrm{O}$ isolamento e clonagem dos promotores de genes de $A g \mathrm{MNPV}$ e $A c \mathrm{MNPV}$ nos plasmídeos de transferência pFAST modificados contendo o gene fluc foram confirmados por PCR, digestão enzimática (dados não mostrados) e sequenciamento Sanger. A estratégia de clonagem dos promotores utilizou a presença das enzimas HindIII e XmaI upstream ao gene repórter no vetor e nos primers utilizados para isolar os promotores para garantir a clonagem direcional dos promotores. Além disto, os plasmídeos foram submetidos a sequenciamento para confirmaram a correta orientação e integridade das sequências nos plasmídeos de transferência (dados não mostrados).

Os bacmídeos resultantes a partir da transformação de células DH10BAC com os plasmídeos pFAST contendo promotores de $A c \mathrm{MNPV}$ e $A g \mathrm{MNPV}$ foram confirmados por PCR utilizando simultaneamente primers específicos aos promotores e um primer que anela no gene fluc (FLUCREV), sendo que os perfis das bandas resultantes são equivalentes às obtidas a partir dos plasmídeos (Figuras 19 e 20). Além desta confirmação, as reações utilizando os primers universais M13 revelaram a presença de bandas $>4.000 \mathrm{pb}$ que indicam a correta transposição dos fragmentos dos plasmídeo 
pFAST nos genomas virais, em contraposição ao controle negativo de colônias azuis não

transpostas que demonstram a integridade do gene LacZ (aproximadamente $300 \mathrm{pb}$ )

(Figura 21). A clonagem dos bacmídeos BACAcPOLH e BACAgPOLH foram

confirmadas utilizando os primers forward de cada promotor e o primer FLUCREV

(Figura 22).

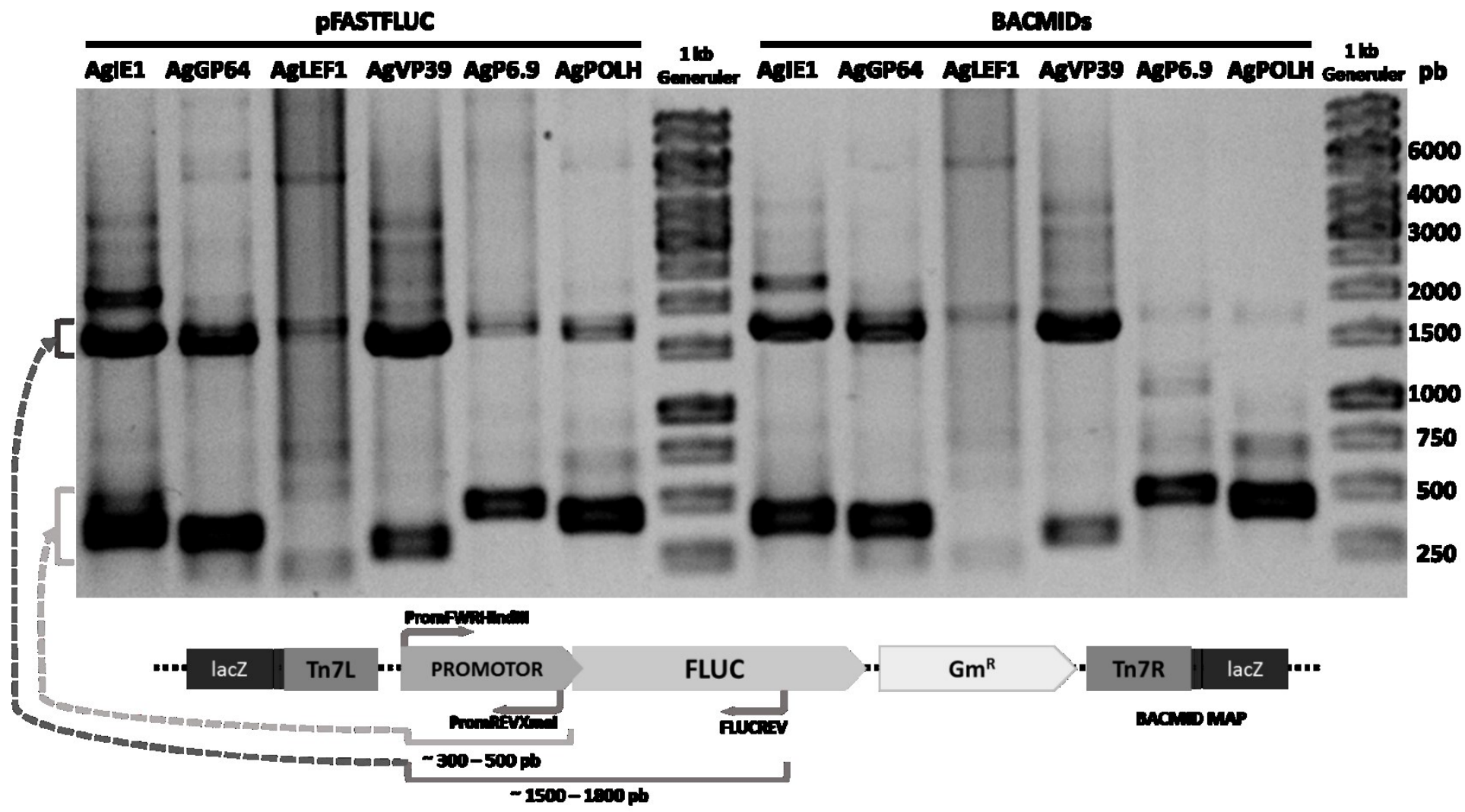

Figura 19: Confirmação da clonagem dos diferentes promotores de AgMNPV comandando o gene fluc no plasmídeo pFastBac1 e no bacmídeo de AcMNPV. Gel de agarose $0.8 \%$ mostrando os resultados da amplificação por PCR utilizando os pares de primers específicos a cada promotor e um primer que se anela no gene fluc com os bacmídeos recombinantes contendo diferentes promotores de AgMNPV como templates da reação de PCR. A amplificação de uma banda de aproximadamente $1600 \mathrm{pb}$ indica a correta posição dos promotores em relação ao gene FLUC dentro do DNA dos bacmídeos. A amplificação de bandas inferiores entre 250 e 500 pb é referente aos promotores isolados individualmente (Tabela 1). 0 marcador de DNA utilizado foi o 1 kb Generuler (Fermentas). 


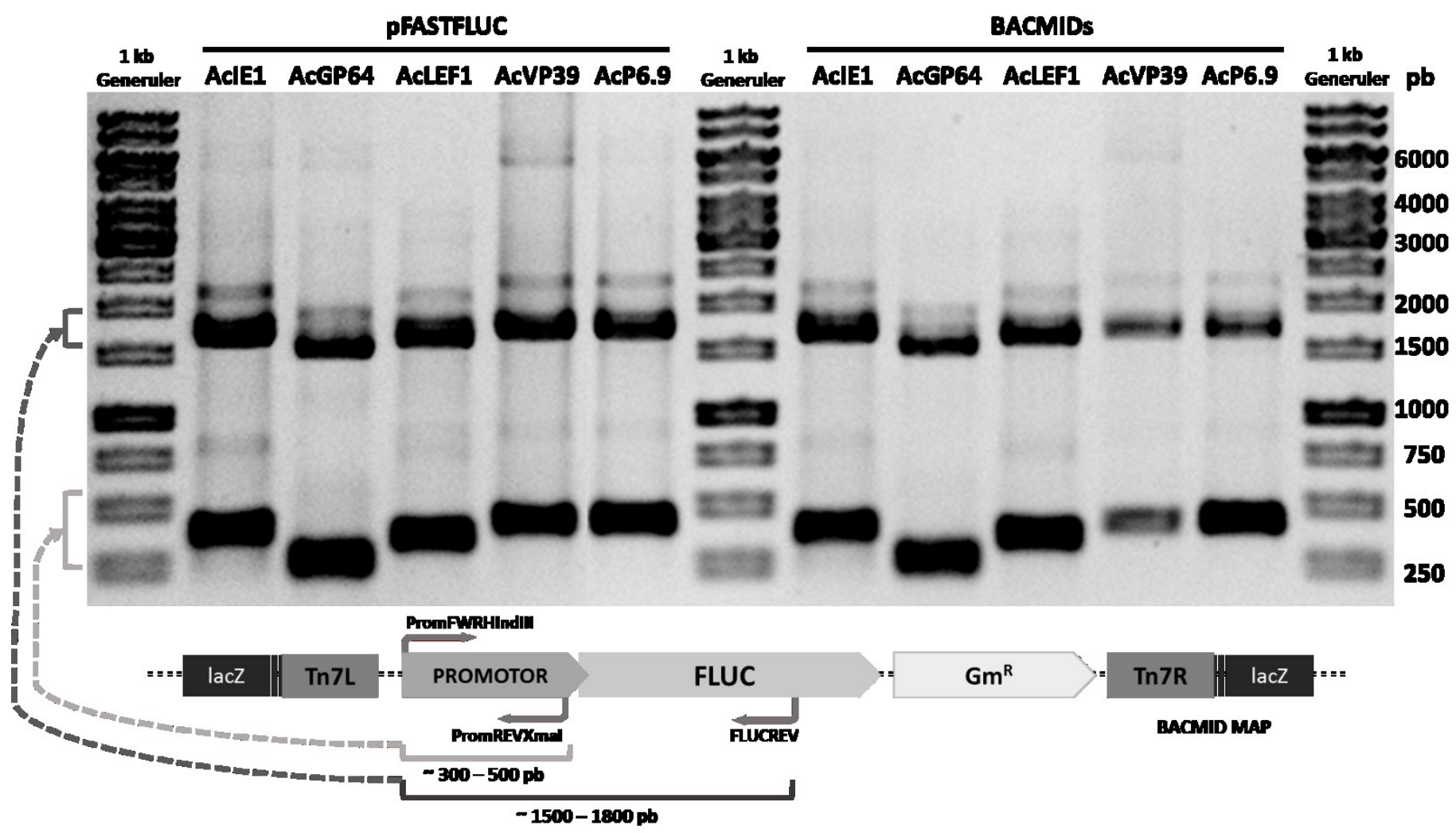

Figura 20: Confirmação da clonagem dos diferentes promotores de AcMNPV comandando o gene fluc no plasmídeo pFastBac1 e no bacmídeo de ACMNPV.Gel de agarose $\mathbf{0 . 8 \%}$ mostrando os resultados da amplificação por PCR utilizando os pares de primers específicos a cada promotor e um primer que anela no gene fluc com os bacmídeos recombinantes contendo diferentes promotores de AcMNPV como templates da reação de PCR. A amplificação de uma banda de aproximadamente 1600 pb indica a correta posição dos promotores em relação ao gene FLUC dentro do DNA dos bacmídeos. A amplificação de bandas inferiores, entre 250 e 500 pb é referente aos promotores isolados individualmente (Tabela 1). 0 marcador de DNA utilizado foi o 1 kb Generuler (Fermentas).

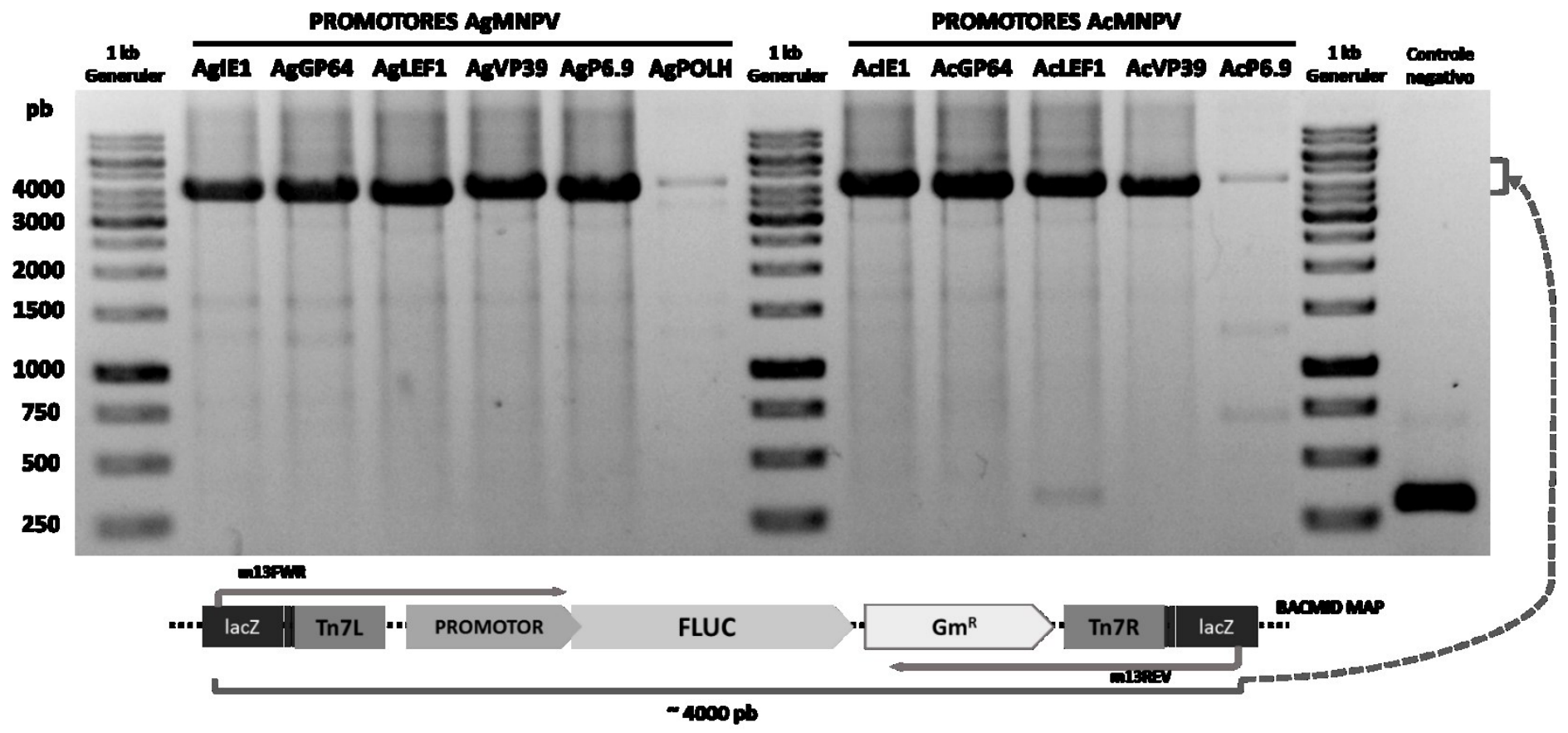

Figura 21: Confirmação da clonagem dos diferentes promotores de AgMNPV e AcMNPV comandando o gene fluc no bacmídeo de AcMNPV. Gel de agarose $\mathbf{0 . 8 \%}$ mostrando os resultados de PCR utilizando os primers universais M13 com os baculovírus recombinantes AcMNPV contendo diferentes promotores de AgMNPV e AcMNPV como templates da reação de PCR. A amplificação de uma banda de aproximadamente 4500 pb indica a correta transposição dos promotores e gene FLUC dentro do DNA dos bacmídeos. $O$ controle negativo indica a amplificação de um amplicon de 300 pb referente ao gene lacZ intacto, sem ter ocorrido a transposição. 0 marcador de DNA utilizado foi o 1 kb Generuler (Fermentas). 


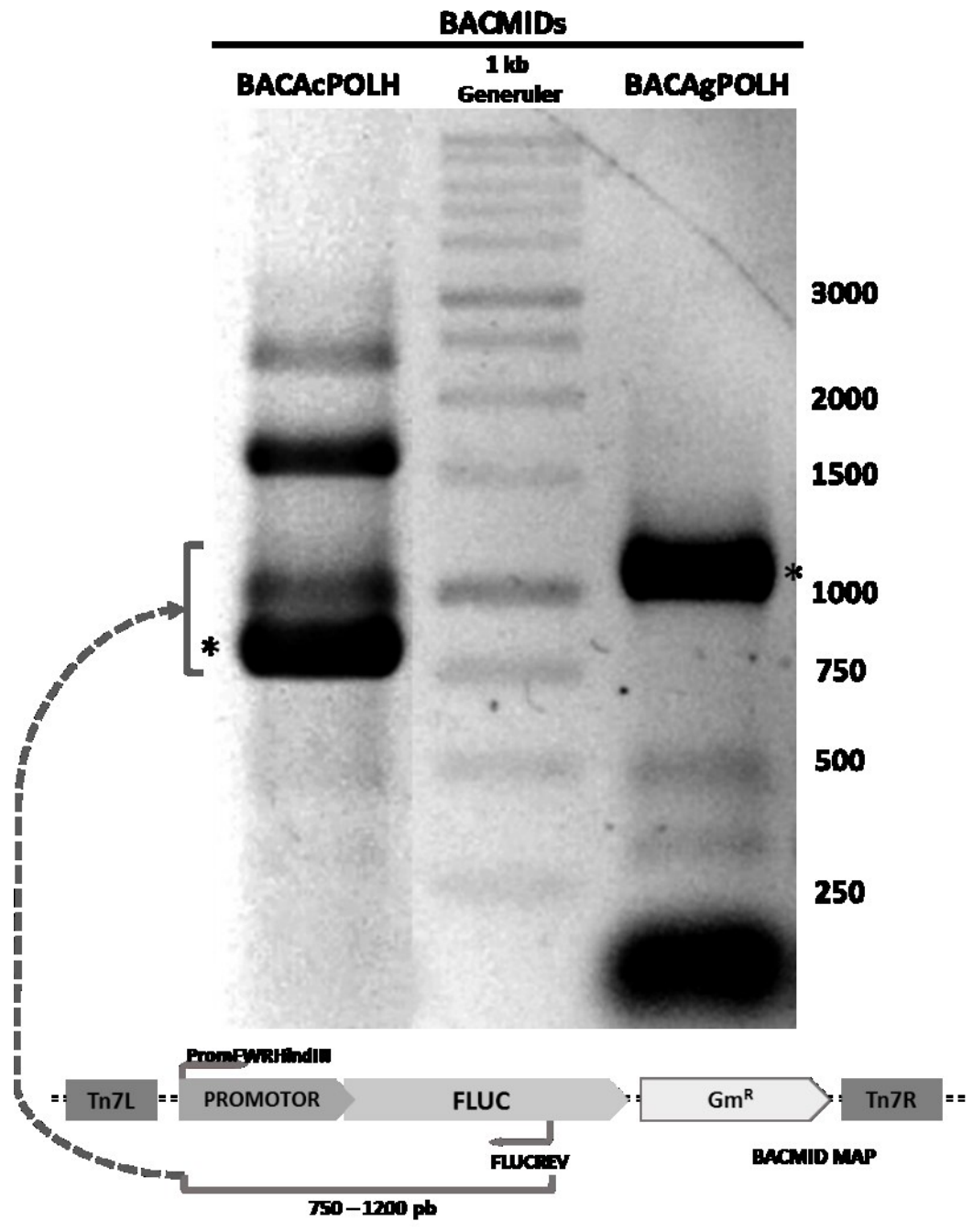

Figura 22: Confirmação da construção dos bacmídeos AcMNPV contendo os promotores AgPOLH de AgMNPV e AcPOLH de AcMNPV comandando o gene fluc nos recombinantes AcMNPV. Gel de agarose $0.8 \%$ mostrando os resultados de PCR utilizando os primers FLUCREV e os primers "forward" (senso positivo) de cada promotor. Os asteriscos marcam as banda de interesse.

O trabalho de Morris \& Miller (1992) foi um dos primeiros estudos realizados com baculovírus $A c \mathrm{MNPV}$ recombinantes utilizando promotores e o gene repórter CAT para cada uma das fases da infecção em diversas linhagens celulares, permissivas e não permissivas a infecção viral. Os resultados deste trabalho seminal apresentaram pela primeira vez o perfil de expressão gênica comparada entre as diferentes fases da expressão, demonstrando a hiperexpressão gênica dos promotores tardios VP39 e muito tardio POLH em células suscetíveis, baixa expressão dos mesmos em células semipermissivas, nula expressão em linhagens não permissivas e a ativação dos 
promotores precoces em células não-perrmissivas. Ao longo dos anos seguintes, diversos promotores de $A c \mathrm{MNPV}$ foram estudados individualmente e dissecados (descritos na seção 4.5). No entanto, a concepção de um estudo comparativo em diversas linhagens celulares nunca foi retomado. Recentemente novos trabalhos estão resgatando estes estudos de expressão gênica mas pelo ângulo da transcrição gênica, graças ao surgimento de técnicas de análise transcriptômica que torna possível avaliar toda a expressão gênica viral em diferentes momentos da infecção (Chen et al., 2013; Choi et al., 2012; Katsuma et al., 2011; Salem et al., 2011). Apesar destes estudos permitirem um detalhamento sem precedentes de toda a transcrição viral, o que contribui muito para a compreensão da biologia da infecção, ainda não é possível dissecar os mecanismos associados aos elementos transcricionais com estas metodologias transcriptômicas. Portanto a manipulação direta dos elementos transcricionais continua sendo uma técnica necessária e fundamental.

Para realizar uma comparação direta da atividade dos promotores de $A c \mathrm{MNPV}$ e $A g \mathrm{MNPV}$ em um mesmo contexto genômico, os baculovírus recombinantes $A c \mathrm{MNPV}$ contendo os promotores de genes equivalentes $A c \mathrm{MNPV}$ e $A g \mathrm{MNPV}$ foram utilizados em infecções controladas de diferentes linhagens celulares. A hipótese fundamental é que os promotores de $A g \mathrm{MNPV}$ manterão suas características mesmo quando clonados no genoma de $A c \mathrm{MNPV}$. Além disto o perfil de ativação dos promotores de $A c \mathrm{MNPV}$ também deve ser similar ao já observado durante a infecção dos AgMNPVs recombinantes. Isto deve ocorrer pois existe uma sequência de ativação gênica específica que garante o progresso da infecção e formação dos dois fenótipos virais em tempos distintos, o que é conservado entre os Alfabaculovírus do grupo I. Este experimento também dá bases para comparar a eficiência dos diferentes promotores na expressão de proteínas pelo sistema BAC-to-BAC. 
Três pontos iniciais devem ser colocados: a construção BACAgIE1FLUC apresentou um perfil de expressão muito distinto ao esperado, com fraca expressão e largos atrasos em todas linhagens testadas. O recombinante BACAgIE1FLUC apresentou curvas de expressão com $\mathrm{T}_{\text {in }}$ muito atrasado ( $>10$ h p.i.) e fraquíssimo pico de expressão, este resultado é considerado inválido pois o promotor imediatamente precoce $A g I E 1$ já demonstrou ser funcional até mesmo quando utilizado em infecções abortivas de células tratadas com afidicolina. Ensaios de transfecção do plasmídeo pFASTAgIE1 em células Tn5B resultaram em expressão gênica dentro de 6 h p.t. (dados não mostrados), além disto o plasmídeo contém a sequência correta conforme identificado no sequenciamento. Portanto é possível que exista algum problema desconhecido durante a construção e seleção do baculovírus recombinante pelo sistema BAC-to-BAC. É possível que o promotor pr $A g I E 1$ seja ineficiente quando clonado no $A c \mathrm{MNPV}$. Isto implicaria na existência de uma incompatibilidade entre os transativadores de $A c \mathrm{MNPV}$ e os elementos cis do promotor prAgIE1. Fenômeno similar a este já foi observado. A proteína IE1 de AcMNPV é capaz de reprimir inícios de transcrição precoces CAGT contendo em sua proximidade a sequência 5'-ACBYGTAA-3', presente por exemplo nos promotores dos genes ie0, ie2 e pe38 (Leisy et al., 1997). No entanto, este motivo em específico é inexistente no promotor $\mathrm{AgIE1}$ isolado (e qualquer dos outros promotores deste trabalho), o que não exclui a possibilidade de que existam outros mecanismos de repressão do vírus $A c \mathrm{MNPV}$ sobre prAgIE1. Os dois promotores possuem alta similaridade relativa em nível de sequências próximas ao início da transcrição com $66 \%$ de identidade total, entre os 376 pb alinhados, e $77 \%$ de identidade nos 40 pb próximos ao núcleo de iniciação da transcrição que também apresentam idênticos conteúdos de GC. As diferenças entre sequências são apenas substituições de A por T e G por C. O perfil de expressão gênica obtido também não condiz com as infecções de vAgIE1FLUC que indicam que este 
promotor é funcional tanto em células permissivas quanto não-permissivas, sendo ativados dentro das primeiras $3 \mathrm{~h}$ de infecção. Portanto é mais provável que exista algum problema na construção do bacmídeo.

Um segundo ponto importante é que os promotores LEF1, tanto de $A g \mathrm{MNPV}$ quanto de $A c \mathrm{MNPV}$, apresentaram padrões distintos dos obtidos durantes as infecções com o vírus vAgLEF1FLUC recombinante nas mesmas células. Os vírus $A c \mathrm{MNPV}$ recombinantes contendo prLEF1 apresentaram valores de $\mathrm{T}_{\text {in }}$ acima de $8 \mathrm{~h}$ p.i e lento acúmulo com $\mathrm{T}_{\text {pi }}$ próximo a $24 \mathrm{~h}$ p.i.. Isto pode ocorrer devido a uma expressão iniciada em fase precoce (<6 h p.i.), mas com lenta aceleração, o que necessita mais tempo para acumular FLUC suficiente até ser detectada. Diferente da situação de baixa atividade com o promotor $A g I E 1$, os dois promotores $A c$ LEF1 e $A g L E F 1$ apresentaram idêntico perfil de expressão dentro do $A c \mathrm{MNPV}$. Isto indica que a expressão de genes da fase precoce atrasada ou aqueles com baixa expressão, em momentos precoces, pelo $A c \mathrm{MNPV}$ é mais fraca do que a expressão dos mesmos pelo $A g \mathrm{MNPV}$. Esta diferença é discutida na próxima seção 4.6, dedicada a comparação entre os perfis de expressão do $A g \mathrm{MNPV}$ e AcMNPV.

$\mathrm{O}$ terceiro ponto se refere ao promotor $\mathrm{pr} A c \mathrm{POLH}$, que apresentou $\mathrm{T}_{\text {in }} 6$ e $5 \mathrm{~h}$ p.i. em Tn5B e UFLAg respectivamente (Tabela 5). Nestes momentos acredita-se que a replicação ainda estaria incipiente e portanto deve existir pouca expressão tardia. Desta forma, o perfil de expressão de BACAcPOLHFLUC é muito distinto do observado em BACAgPOLHFLUC e vAgPOLHFLUC que consistentemente apresentam um perfil muito tardio ( $\mathrm{T}_{\text {in }}>10 \mathrm{~h}$ p.i.). A ativação de prAcPOLH ocorreu antecipadamente aos promotores tardios VP39 e P6.9. Como já observado durante as infecções com os $A g$ MNPVs recombinantes, o promotor muito tardio $A g P O L H$ é ativado com diferenças de $\mathrm{T}_{\text {in }}$ de $3 \mathrm{~h}$ ou mais em relação ao elemento $A g \mathrm{P} 6.9$. A comparação entre promotores 
tardios e muito tardios do $A c \mathrm{MNPV}$ que também já foi descrito em outros trabalhos que descreveram uma grande distinção entre VP39 (entre 12 e 24 h p.i.) e POLH (crescimento entre 24 e 48 h p.i.) (Thiem \& Miller, 1990). Os ensaios com o baculovírus AgMNPV estão mais de acordo com a descrição na literatura do que os bacmídeos contendo o promotor AcPOLH.

Como a expressão gênica destes dois elementos $A g I E 1$ e $A c P O L H$ foram muito distintas do esperado, consideramos que os bacmídeos construídos com os elementos citados estão defectivos e serão desconsiderados nas interpretações dos perfis globais de expressão de cada célula.

Tabela 5: Tempo de primeira detecção $\left(T_{\text {in }}\right)$ do sinal de luminescência (hh:mm), ensaio com os baculovírus AcMNPV recombinantes contendo os promotores de AcMNPV e AgMNPV em diferentes linhagens derivadas de Lepidoptera.

\begin{tabular}{cccc|c|c|c}
\hline Linhagem & \multicolumn{7}{c}{ Vírus - BACAcpromFLUC } \\
\hline & IE1FLUC & GP64FLUC & LEF1FLUC & VP39FLUC & P6.9FLUC & POLHFLUC \\
& Média & Média & Média & Média & Média & Média \\
\hline Tn5B & $0: 54$ & $1: 51$ & $14: 04$ & $10: 41$ & $8: 39$ & $6: 02$ \\
UFLAg & $6: 32$ & $6: 14$ & $9: 18$ & $8: 12$ & $8: 57$ & $5: 45$ \\
Sf9 & $2: 11$ & $14: 00$ & $22: 07$ & $17: 34$ & $16: 45$ & $9: 29$ \\
Ld652Y & $2: 15$ & $4: 35$ & & $12: 49$ & $12: 55$ & $12: 09$ \\
Chch & $4: 03$ & $36: 38$ & $112: 16$ & $21: 25$ & $21: 08$ & $15: 36$ \\
Bm5 & $2: 46$ & $2: 42$ & $6: 26$ & $67: 52$ & $58: 35$ & \\
\hline Linhagem & & & Vírus - BACAgpromFLUC & & \\
\hline & IE1FLUC & GP64FLUC & LEF1FLUC & VP39FLUC & P6.9FLUC & POLHFLUC \\
\hline Tn5B & Média & Média & Média & Média & Média & Média \\
\hline UFLAg & $15: 28$ & $0: 14$ & $13: 19$ & $7: 53$ & $8: 00$ & $7: 31$ \\
Sf9 & 27:26 & $1: 42$ & $8: 39$ & $6: 43$ & $9: 05$ & $14: 52$ \\
Ld652Y & $23: 21$ & $5: 52$ & $22: 56$ & $15: 11$ & $17: 15$ & $13: 58$ \\
Chch & $24: 33$ & $1: 25$ & $16: 51$ & $12: 09$ & $12: 41$ & $21: 01$ \\
Bm5 & & $1: 38$ & $46: 39$ & $15: 46$ & $23: 50$ & \\
\hline
\end{tabular}

A figura 23 e a tabela 5 apresentam os dados de infecção nas linhagens Tn5B (Figura 23 B1 e B2) e Sf9 (Figura $23 \mathrm{C} 1$ e C2), consideradas como permissivas ao 
AcMNPV (Rohrmann, 2013); e UFLAg (Figura 23 A1 e A2), considerada como semipermissiva ao mesmo vírus. O perfil de expressão dos promotores, independente de qual vírus foram isolados, nestas células observou-se a ativação de todos os promotores precoces e tardios, mas a sequência de ativação dos promotores tardios VP39, p6.9 e POLH não ficou clara, com pouca diferença em $T_{\text {in }}$ (Tabela 5). As linhagens Tn5B e UFLAg apresentaram os maiores valores de pico de expressão entre 24 e 48 h p.i. a partir dos promotores VP39 e p6.9, 10 a 20 vezes superiores ao promotor POLH. A linhagem Sf9 apresentou os níveis mais baixos de luminescência para os promotores tardios, que atingem $\mathrm{V}_{\max }$ próximos ao dos promotores prIE1 e prGP64. Observação similar foi feita durante a infecção de $A g M N P V s$ recombinantes nesta célula. 


\section{BACAcpromFLUC}
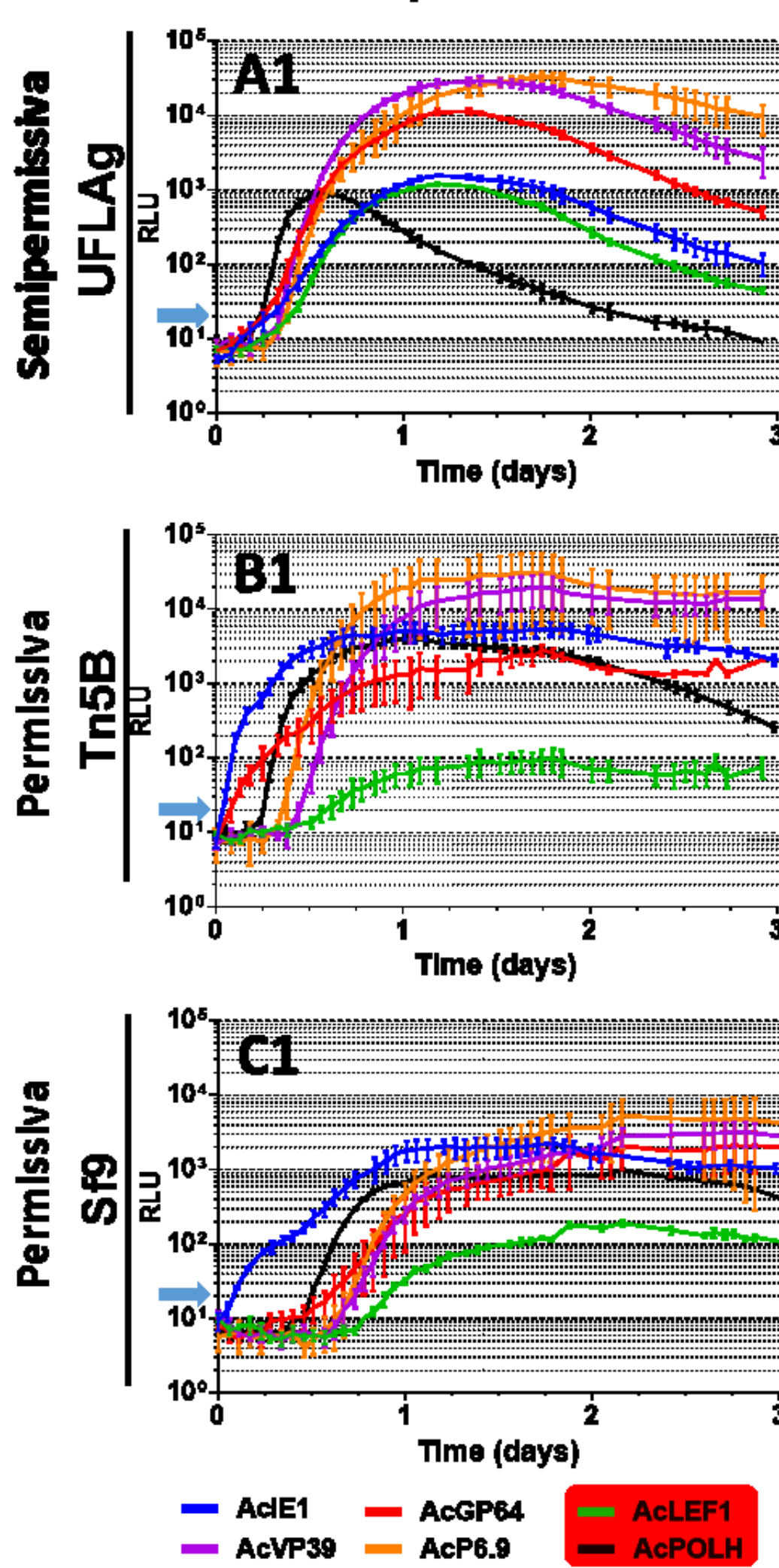

BACAgpromFLUC

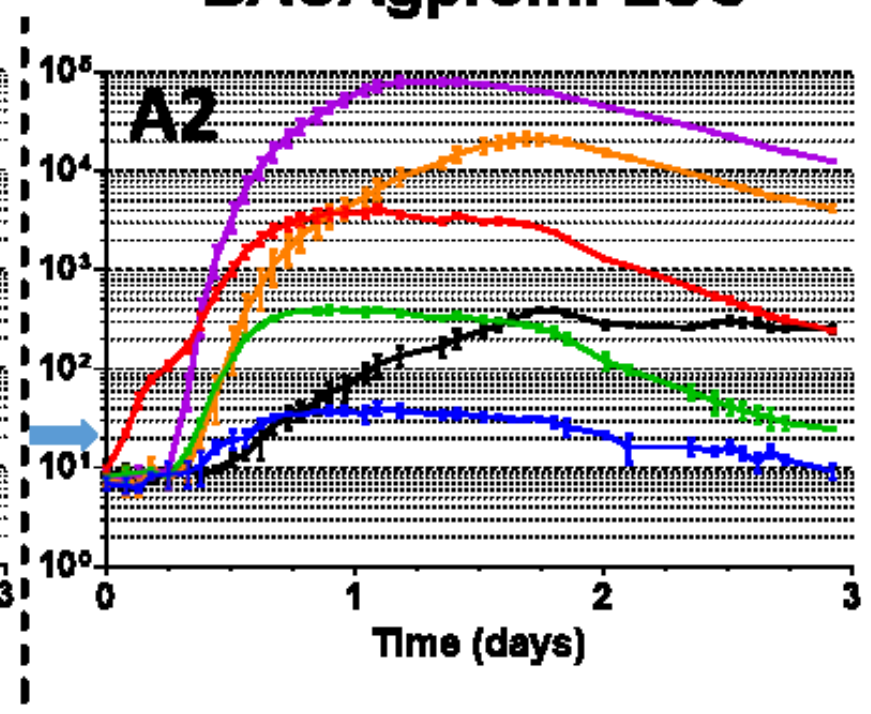

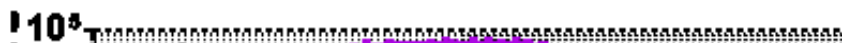
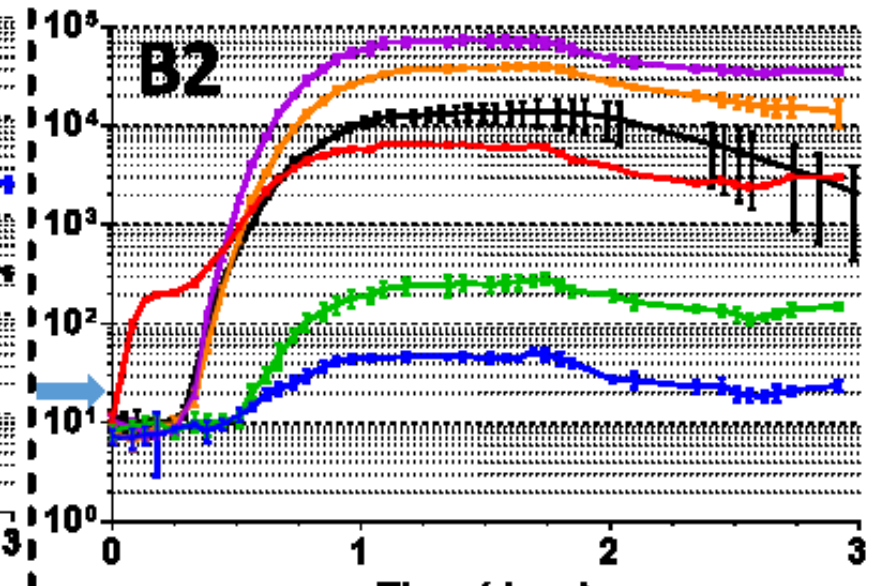

:

i

TIme (days)
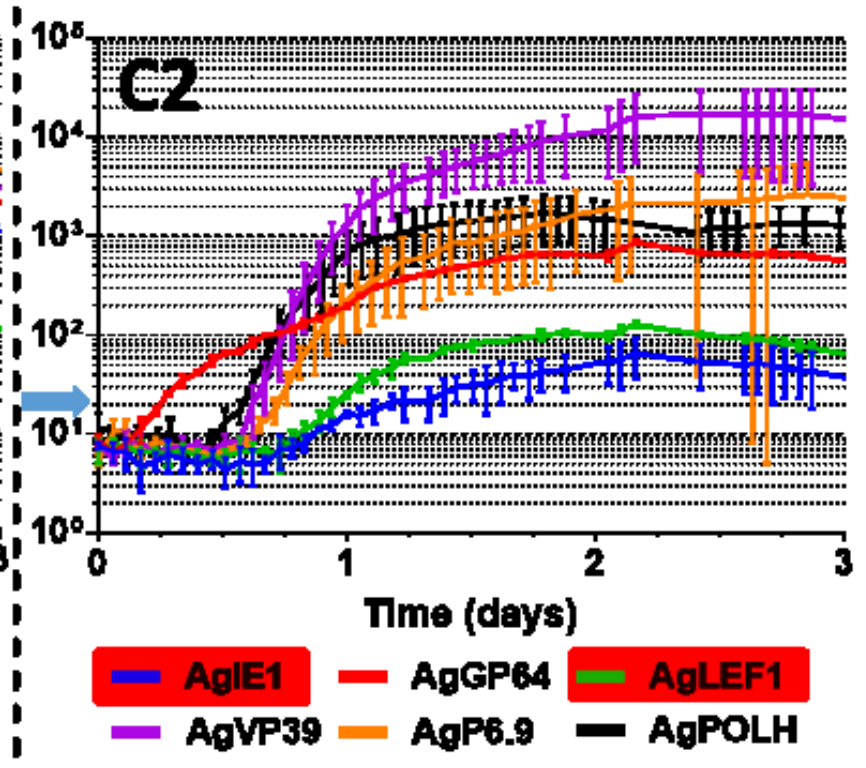

Figura 23: Ensaios de medição contínua de luminescência das infecções com os baculovírus AcMNPV recombinantes contendo promotores de AcMNPV (coluna esquerda) e AgMNPV (coluna direita) nas linhagens UFLAg, Tn5B e Sf9 ao longo de 3 dias de infecção em $\mathrm{MOI}$ 10. As setas em azul no eixo $\mathrm{Y}$ indicam o valor basal de luminescência (20 RLU). Os intervalos entre medições são variáveis. 
A figura 24 e a tabela 5 apresentam os dados das infecções nas linhagens Ld652Y (Figura 24 A1 e A2), Bm5 (Figura 24 B1 e B2) e Chch (Figura 24 C1 e C2). Observando os promotores, independente do vírus de origem, observamos os seguintes pontos: A linhagem Ld652Y foi capaz de ativar todos os promotores, com uma lenta ascenção de sinal ( $\mathrm{T}_{\mathrm{pi}}>48 \mathrm{~h}$ p.i.). Os promotores tardios VP39 e p6.9 apresentaram níveis altos, em $10^{5}$ RLU às 72 h p.i.. No entanto o promotor POLH falhou em realizar alta expressão gênica, portanto não ocorre hiperexpressão deste promotor muito tardio nesta célula. A linhagem Bm5 é considerada não-permissiva (Argaud et al., 1998). Conforme observado nos sinais muito fracos dos promotores precoces, esta células aparentemente bloqueou o progresso da infecção de $A c \mathrm{MNPV}$ em momentos precoces, no entanto uma atividade fraca dos promotores tardios VP39 e p6.9 foi detectada acima do nível basal em 72 h p.i., fenômeno que não ocorreu durante as infecções totalmente bloqueadas do $A g \mathrm{MNPV}$ nesta linhagem (Figura 10). Isto indica que o $A c \mathrm{MNPV}$ possui elementos capazes, mas ineficientes, de sobrepor a limitação a infecção inerente nesta linhagem.

Ainda observando os promotores independente do vírus de origem, na linhagem celular Chch foram obtidos os menores valores de luminescência, com fraca expressão dos promotores precoces IE1 e GP64 e uma expressão praticamente basal dos promotores LEF1 ao longo de $72 \mathrm{~h}$, os promotores tardios VP39 e p6.9 também foram ativados mas atingem baixos níveis de expressão. Os perfis de Chch e Bm5 foram muito similares, e com base no perfil dos promotores, a linhagem Chch deve ser considerada não-permissiva ao $A c \mathrm{MNPV}$. Nesta linhagem também não foi observada a ativação dos promotores POLH. 
BACAcpromFLUC
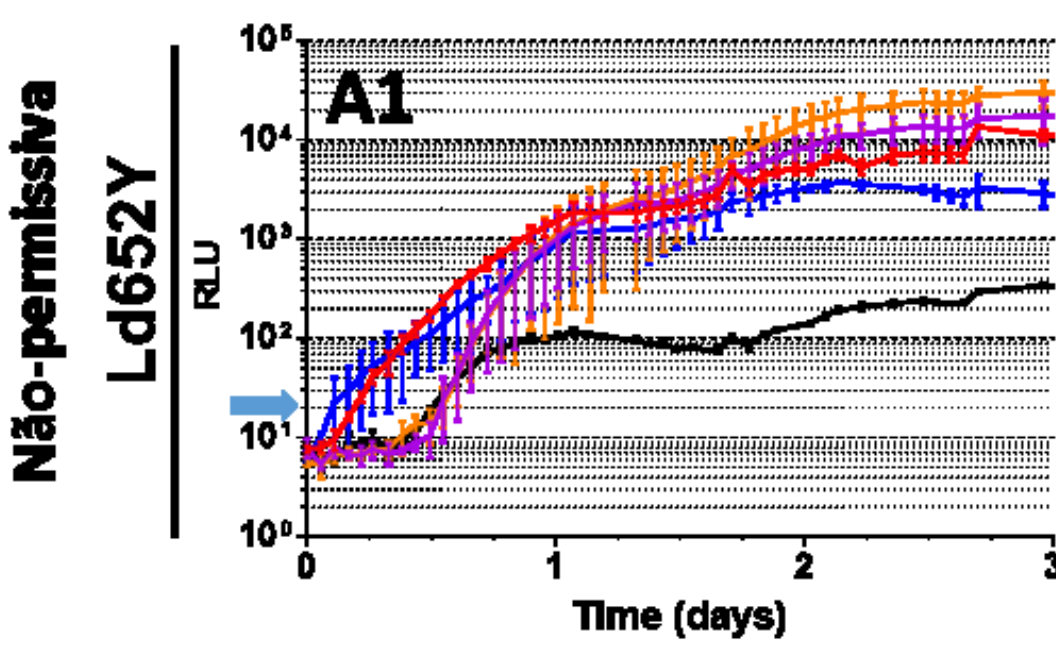

$\frac{8}{4}$

\section{BACAgpromFLUC}
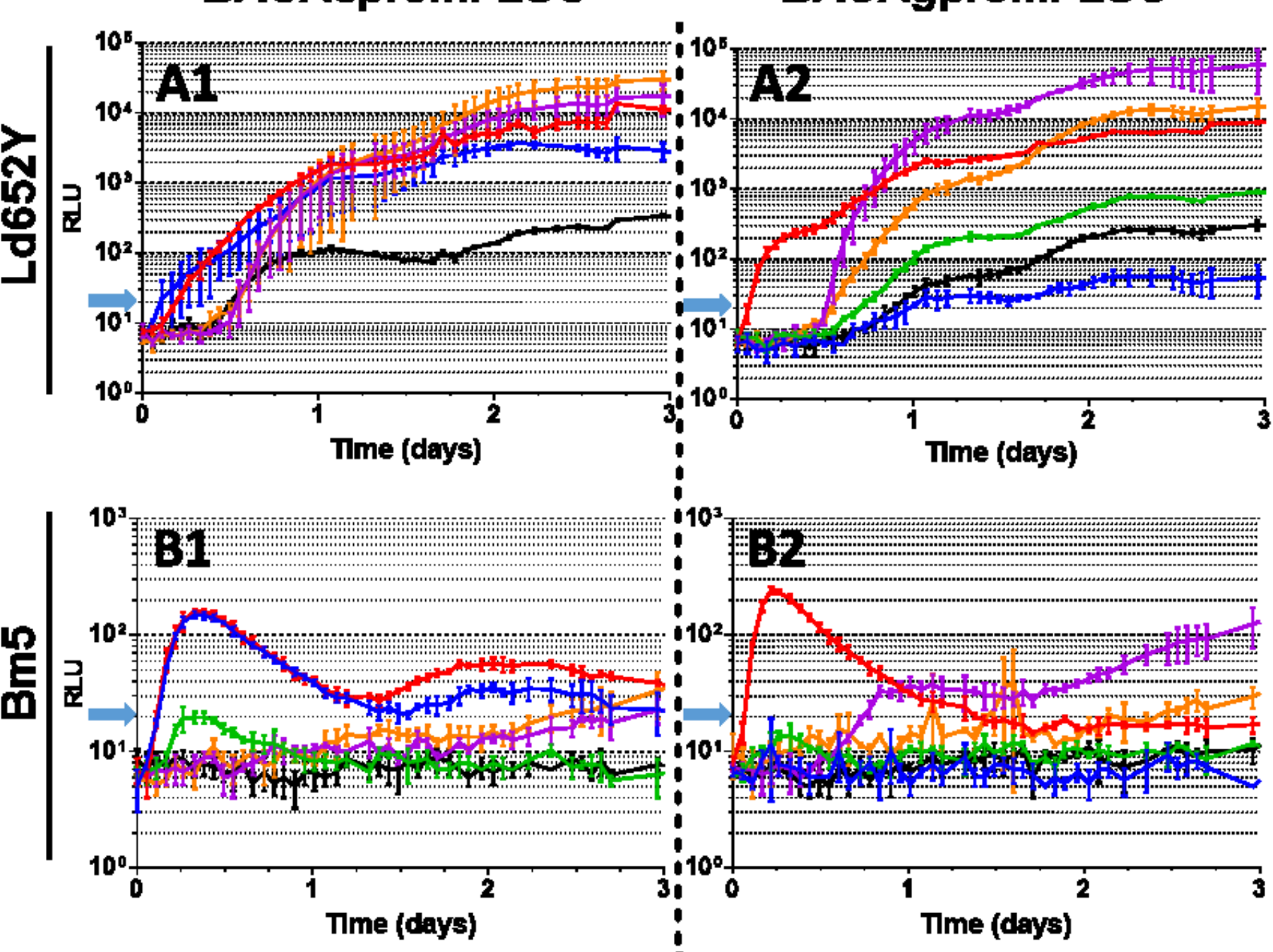

$10^{3}$

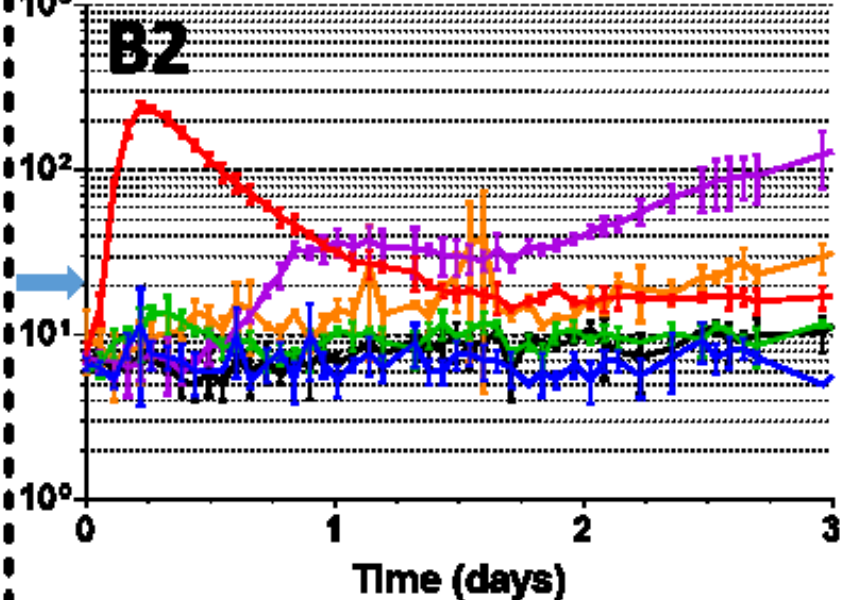

$\frac{8}{8}$

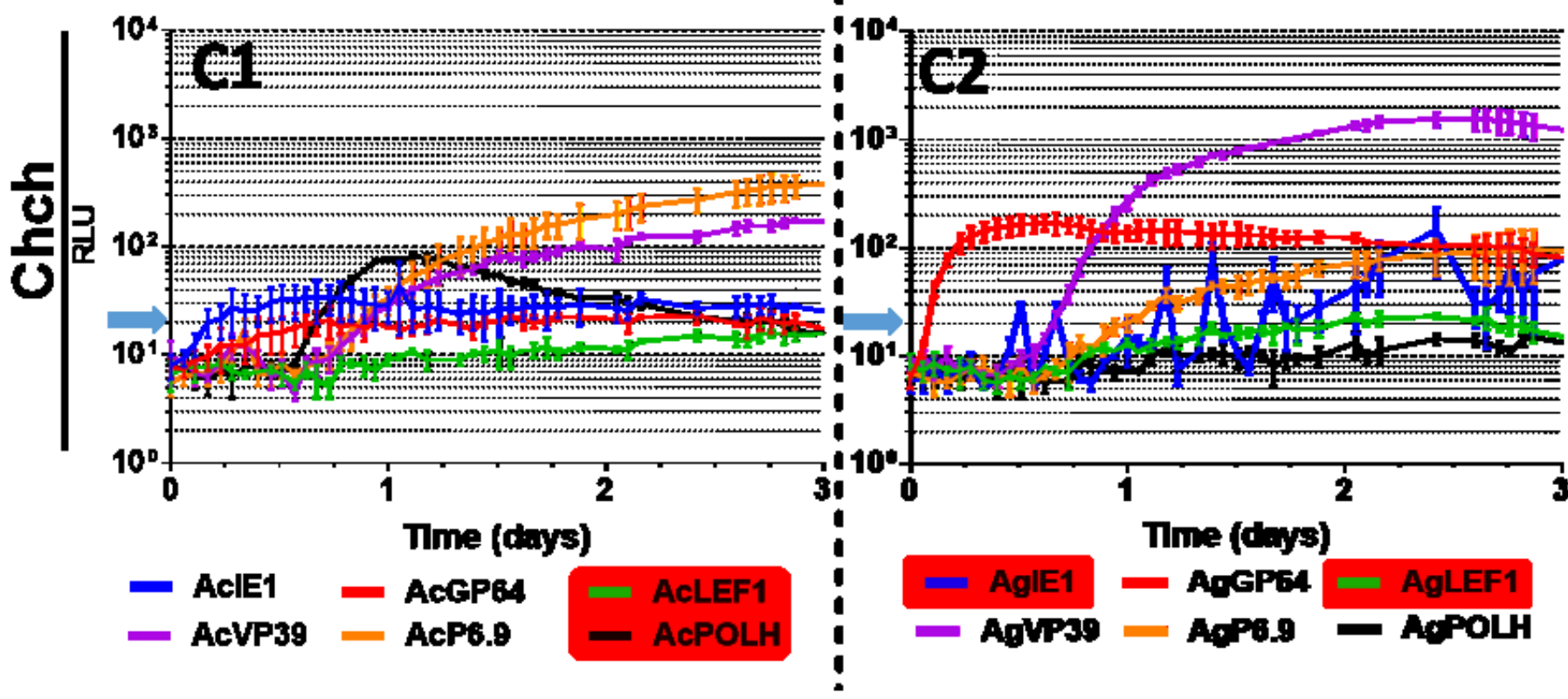

Figura 24: Ensaios de medição contínua de luminescência das infecções com os baculovírus $A c M N P V$ recombinantes contendo promotores de AcMNPV (coluna esquerda) e AgMNPV (coluna direita) nas linhagens Ld652Y, Bm5 e Chch ao longo de 3 dias de infecção em MOI 10. As setas em azul no eixo $Y$ indicam o valor basal de luminescência (20 RLU). Os intervalos entre medições são variáveis. 
Uma observação inesperada foi que os promotores pr $A c \mathrm{VP} 39$ e prAgVP39 não foram capazes de iniciar expressão detectável em momentos precoces atrasados (entre 3 e 6 h p.i.), fenômeno observado durante as infecções com o $A g$ MNPV recombinante vAgVP39FLUC. Os maiores $\mathrm{V}_{\max }$ e menores $\mathrm{T}_{\mathrm{pi}}$ foram obtidos com o promotor $\operatorname{pr} A g \mathrm{VP} 39$, indicando que este promotor é o mais eficiente para a expressão de proteínas utilizando o sistema BAC-to-BAC, seguido por $\operatorname{pr} A c \mathrm{P} 69$, $\operatorname{pr} A g \mathrm{P} 69$ e prAcVP39. Os promotores VP39 de ambos vírus apresentaram perfis de expressão muito similares entre si e também em relação aos promotores P6.9. Entretanto, a expressão de prAgVP39 durante a infecção de todas linhagens celulares testadas em momentos precoces atrasados era esperada (Figura 5) e não ocorreu, indicando que a capacidade bimodal de pr $A g$ VP39 falhou durante a infecção pelo baculovírus $A c \mathrm{MNPV}$.

Outro ponto interessante observado foi a natureza bimodal do promotor prAgGP64, facilmente observada na infecção das linhagens UFLAg e Tn5B (Figura 23 A2 e B2, respectivamente), que apresentou um leve patamar entre 2 e $8 \mathrm{~h}$ p.i. e retomou um rápido crescimento de sinal em diante, até o segundo pico em 24 h p.i. Este segundo aumento é atribuído ao uso do motivo tardio de transcrição contido neste promotor além do precoce. Este fenômeno não foi observado para o promotor prAcGP64. O atraso em $\mathrm{T}_{\text {in }}$ (Tabela 5) e fraca expressão em momentos precoces de prAcGP64 é muito distinto da rápida ativação e forte expressão de prAgGP64. Isto vai em contraponto com a concepção de expressão imediatamente precoce para promover a proliferação sistêmica em intestinos de larvas durante a infecção oral (Engelhard et al., 1994; Washburn et al., 2003, 1999). É também distinto da descrição anterior deste elemento como um promotor bimodal precoce e tardio de forte expressão (Blissard \& Rohrmann, 1991; Garrity et al., 1997; Kogan et al., 1995). 
O elemento prAgGP64 apresentou um perfil praticamente idêntico ao ocorrido durante infecção de Tn5B e UFLAg com os AgMNPVs (Figura 4), com dois nítidos picos de expressão, o primeiro a partir de 6 h p.i. e o segundo a partir de 24 h p.i.. Como o elemento prAcGP64 não apresentou esta característica bimodal de forma consistente, como o $\operatorname{pr} A g G P 64$, isto sugere que existem distinções entre este promotores a serem exploradas, potencialmente relativas à adaptação e otimização da expressão deste gene pelos dois vírus de hospedeiros naturais distintos. A identidade de sequência total entre estes dois promotores é relativamente baixa (58\%), mas o núcleo transcricional detectado como INR em AcGP64 (Chen et al., 2013) permanece conservado no AgMNPV (CAGT contendo TATA box a distância -30 pb). As maiores distinções ocorrem na região a montante deste INR. Nestas regiões os motivos da fase tardia em prAcGP64 são topologicamente distintos, isto é, ambos promotores contém a mesma quantidade de motivos mas em posições distintas. A diferença entre estes promotores pode ocorrer por duas razões, o locus do gene gp64 em AgMNPV contém um gene exclusivo a este vírus denominado de v-trex, indicando que esta região sofreu recombinações recentes para incluir este gene (Slack et al., 2004). Portanto, o promotor prAgGP64 pode ter sofrido um processo de seleção e otimização dentro do genoma do $A g \mathrm{MNPV}$ distinto do que ocorreu em $A c \mathrm{MNPV}$. Isto explicaria a grande distinção entre os promotores GP64 de $A c \mathrm{MNPV}$ e $A g M N P V$. O gene gp64 dos baculovírus é absolutamente essencial à formação de BVs, e a expressão em momentos imediatamente precoces contribui para a rápida proliferação sistêmica do vírus após infecção primária no intestino de larvas, o que implica em um processo seletivo específico sobre este promotor, voltado à otimização da rápida transcrição imediatamente precoce.

Olhando agora para os perfis de expressão em cada célula como um todo, todas as linhagens apresentaram perfis similares de expressão gênica quando comparamos os 
promotores derivados de $A c \mathrm{MNPV}$ com os derivados de $A g \mathrm{MNPV}$. Foi observada a mesma sequência de ativação dos promotores e proporções relativas de intensidade muito similares. As linhagens Tn5B e UFLAg apresentaram a expressão precoce mais rápida e os maiores sinais de expressão em especial dos promotores tardios VP39 e P6.9, além de alta expressão do promotor prAgPOLH em momentos muito tardios. A proporção da expressão destes elementos também é muito similar ao detectado no transcriptoma do AcMNPV infectando Tn5B (Chen et al., 2013), que descreveu os genes $v p 39$ e $p 6.9$ como os mais intensos.

A comparação dos perfis de expressão dos promotores durante a infecção com os $A c \mathrm{MNPV}$ recombinantes em UFLAg é especialmente interessante pois esta linhagem é descrita como semipermissiva ao $A c \mathrm{MNPV}$ devido à baixa produção de poliedros (Oliveira et al., 2011). Ocorreu baixa expressão a partir dos promotores precoces prAcGP64 e prAcIE1 durante as primeiras $6 \mathrm{~h}$ p.i. (Figura 23 A1), enquanto que prAgGP64 (Figura 23 A2) foi mais produtivo durante este período. Esta diferença é difícil de ser explicada pela similaridade dos promotores, pois como comentado anteriormente, o núcleo transcricional da fase precoce em ambos elementos prGP64 é conservado. De forma similar, a ineficiência do elemento prAcIE1 indica a existência de restrições impostas por esta célula sobre a infecção do $A c \mathrm{MNPV}$ em momentos precoces. A reduzida expressão do promotor prAcIE1 também sugere potencialmente redução na expressão do transativador IE1 que teria um efeito redutor sobre a expressão dos genes posteriores, no entanto, observamos uma forte expressão dos promotores tardios em momentos apropriados. A forte expressão dos promotores tardios é consistente com a observação que Sf9 é capaz de produzir altos títulos virais a partir da infecção de AcMNPV (Lynn, 2003) enquanto a fraca expressão do promotor AgPOLH (Figura 23 A2) explica a baixa quantidade de poliedros formados em momentos muito tardios. Em 
conjunto, estes resultados apontam que esta linhagem celular afeta negativamente a transcrição gênica precoce do $A c \mathrm{MNPV}$, com efeito pronunciado sobre os promotores derivados deste mesmo vírus e efeito ainda mais prevalente sobre o promotor muito tardio AgPOLH.

A linhagem Sf9 apresentou um perfil de expressão com atraso geral na ativação dos promotores ( $T_{\text {in }}>12$ h p.i.) em relação a Tn5B e UFLAg. A célula Sf9 é comumente utilizada para propagar o vírus $A c \mathrm{MNPV}$ por produzir alto títulos de BV mas em contraste é menos produtiva do que Tn5B em termos de expressão de proteínas heterólogas (Wilde et al., 2014). Ensaios de quantificação da transcrição por microarranjo demonstraram que ocorre intensa expressão gênica dentro das primeiras $12 \mathrm{~h}$ p.i. com picos de expressão de genes precoces a $24 \mathrm{~h}$ p.i. e picos de genes tardios a $48 \mathrm{~h}$ p.i. (Iwanaga et al., 2004). O atraso na atividade dos promotores está em desacordo com dados de transcriptômica por microarranjo, que identificaram por exemplo a atividade transcricional do gene gp64 dentro das primeiras horas de infecção pelo $A c \mathrm{MNPV}$. É interessante observar que o promotor $A g G P 64$ não foi ativado até 3 h p.i. (Tabela 5, Figura $23 \mathrm{C} 2$ ), enquanto o promotor $A c \mathrm{GP} 64$ (Figura $23 \mathrm{C} 1$ ) teve um atraso ainda maior com $\mathrm{T}_{\text {in }}$ próximo a $6 \mathrm{~h}$ p.i. (Tabela 5). Efeito similar de atraso na expressão desta célula foi detectado durante a infecção dos $A g \mathrm{MNPV}$ recombinantes (Figura 9), o que sugere uma eficiência de transcrição e expressão gênica reduzida nesta célula. Após 48 h p.i., todos promotores tardios foram capazes de sobrepor o nível de expressão dos precoces, mas a diferença relativa entre estes foi menor do que a observada nas linhagem UFLAg e Tn5B, novamente sugerindo que esta linhagem possui uma habilidade de expressão reduzida.

A infecção na linhagem Ld652Y apresentou um perfil de expressão mais atrasado, com valores iniciais de promotores tardios próximos a $12 \mathrm{~h}$ p.i. (Tabela 5) e picos de expressão a 72 h p.i.. Todos os promotores foram ativados e atingiram níveis altos de 
luminescência no pico de expressão. Em distinção ao AgMNPV, os promotores POLH foram ativados, em especial pr $A g P O L H$, com $\mathrm{T}_{\text {in }}$ às 18 h p.i. (Figura 9 e 10, Tabela 2). A expressão dos promotores ao longo de 72 h ou mais (com picos até 96 h p.i., dados não mostrados) não está de acordo com o fenômeno já citado e bem estudado do bloqueio global de síntese de proteínas induzidas pelo $A c \mathrm{MNPV}$ após a replicação do vírus (Guzo et al., 1992; Schultz \& Friesen, 2009; Thiem \& Chejanovsky, 2004). Neste cenário, ao bloquear a via de apoptose utilizando o gene antiapoptótico p35, a célula é capaz de bloquear a síntese proteica da fase tardia e assim inibir a formação de progênie viral por mecanismos ainda desconhecidos. Quando o gene hrfl de LdMNPV é clonado no $A c \mathrm{MNPV}$, o bloqueio não ocorre, portanto esta segunda defesa celular também é passível de ser desarmada por genes virais (Thiem et al., 1996). A ativação dos promotores tardios e contínuo aumento até níveis maiores que os promotores precoces são indícios que a replicação viral ocorre na célula mas a velocidade em que as curvas atingem o pico sugerem uma replicação ineficiente, como quantificada durante as infecções com o $A g \mathrm{MNPV}$, no entanto não ocorre uma redução global da síntese de proteínas como os perfis de expressão claramente indicam, o observado é mais um retardo na expressão.

A infecção das linhagens não-permissivas Chch (Figura 24 C1 C2) e Bm5 (Figura 24 B1 B2) apresentam perfis nitidamente abortivos. A infecção de $A c$ MNPV na linhagem Chch já foi descrita como abortiva pois a célula entra em apoptose após 24 h p.i. e é capaz de expressar tanto o gene polh (medido por western blot) quanto expressar a partir do pr $A c$ POLH (testado usando $A c \mathrm{MNPV}$ recombinante utilizando GFP controlada pelo promotor $A c \mathrm{POLH})$ mas produz título viral muito reduzido em comparação ao título resultante da infecção do vírus ChchSNPV e TniSNPV (Xu et al., 2010). Nesta tese, confirmamos por microscopia de luz que de fato ocorre apoptose as $24 \mathrm{~h}$ p.i. durante infecções de Chch com o $A c \mathrm{MNPV}$. A expressão precoce ocorre rapidamente (Tabela 5) 
mas atinge baixos picos de expressão em $12 \mathrm{~h}$ p.i., seguida por expressão fraca dos promotores tardios. Distinto do trabalho citado, não foi observada atividade do promotor prAgPOLH até 72 h p.i. (Figura 24 C2). Apesar de não ter sido quantificado o DNA viral intracelular, o resultado obtido indicando expressão de promotores tardios, mesmo fraca, sugere que a linhagem é capaz de replicar o DNA viral pois a ativação destes depende da replicação. Os promotores de $A g \mathrm{MNPV}$ apresentaram uma expressão um pouco superior (Figura $24 \mathrm{C} 2$ ) que os promotores de $A c \mathrm{MNPV}$ (Figura $24 \mathrm{C} 1$ ), mas ainda muito similares temporalmente.

A linhagem não-permissiva Bm5 infectada pelos AcMNPV recombinantes apresentou um perfil de expressão inibida (Figura 24 B1 e B2), muito similar a infecção produzida pelo $A g \mathrm{MNPV}$ (Figura 6) com rápida expressão de prAcIE1 e prAcGP64 (Figura 24 B1) que atingem picos em níveis baixos de expressão a 12 h p.i. e retornam a níveis basais de expressão após 24 h p.i.. A expressão de genes tardios ocorre muito fracamente, oscilando próximo a níveis basais $3 \mathrm{~d}$ p.i.. A única diferença marcante entre os promotores de $A c$ ou $A g \mathrm{MNPV}$ nesta linhagem não-permissiva foi a expressão mais intensa a partir de pr $A g$ VP39 em comparação ao pr $A c$ VP39 (Figura 24 B2). Um perfil de expressão consistente a partir de promotores precoces mas expressão insignificante, senão ausente, de promotores tardios também foi observado durante as infecções com os AgMNPV recombinantes e conforme os dados de replicação apresentados anteriormente. Utilizando os perfis de expressão obtidos, podemos prever que a replicação do $A c \mathrm{MNPV}$ é muito limitada mas foi possível observa a ativação dos promotores tardios dependentes da replicação. As descrições anteriores desta infecção de Bm5 pelo AcMNPV já afirmaram não existir replicação ou produção de proteínas virais tardias (Argaud et al., 1998; Mukherjee et al., 1995). É possível que a metodologia utilizada neste trabalho utilizando Luciferase seja mais sensível que as utilizadas nos trabalhos citados e capaz de 
detectar a fraca expressão a partir dos promotores tardios. Portanto a infecção pelo $A c \mathrm{MNPV}$ é potencialmente "mais permissiva" que a de $A g \mathrm{MNPV}$ nesta linhagem, em que os promotores tardios sequer foram ativados.

\subsection{Correlação entre atividade dos promotores, motivos dos promotores e função gênica}

Apesar deste estudo ter sido realizado utilizando os promotores e não os genes, deslocados de sua posição original na topologia do genoma viral e incluídos em um locus onde observa-se alta expressão gênica (locus do gene da poliedrina), estes ainda são capazes de manter características únicas. A implicação maior é que estes elementos de controle da expressão são modulares em relação à sequência codificadora que controlam, evoluindo de forma independente, mas associada, para otimizar a infecção celular pelo ajuste da intensidade e momento de expressão de cada gene. Para contextualizar melhor a importância dos elementos de controle da expressão durante a infecção celular, teceremos algumas associações entre as características de expressão dos promotores, os motivos de transcrição conhecidos e as funções dos genes que estes controlam.

\subsubsection{IE1}

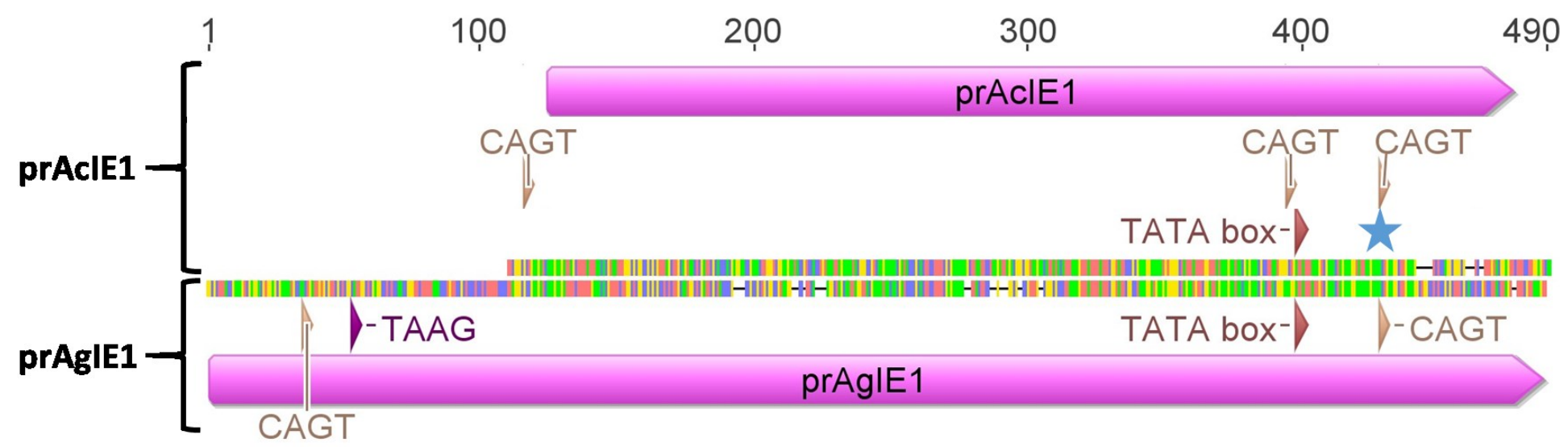

Figura 25: Alinhamento dos promotores IE1 de AcMNPV e AgMNPV. As coordenadas das sequências estão acima. As sequências estão apresentadas em cores modo Clustal. Os motivos de transcrição foram identificados apropriadamente. Os sítios de início de transcrição em momentos precoces do promotor de AcMNPV estão apontados na sequência com a estrela azul, conforme descrito em (Chen et al., 2013). 
A proteína Immediate Early 1 (IE1) é um dos elementos chaves da infecção de baculovírus em células de inseto, seu gene é essencial e codifica uma proteína (67 kDa) altamente conservada entre Alpha e Betabaculovirus (Miele et al., 2011). A estrutura terciária forma dímeros de IE1 com capacidade de associação específica às sequências palindrômicas contidas nas regiões homólogas, o que auxilia na formação do estroma virogênico no núcleo celular (Nagamine et al., 2005) e associação não específica a motivos de promotores da fase precoce (INR precoce e TATA box, Slack \& Arif, 2007). Estas duas atividades resultam na transativação da expressão gênica de promotores da fase precoce (Pullen \& Friesen, 1995), ressaltando que IE1 estimula a transcrição de qualquer promotor precoce mínimo que contenha um TATA box (Blissard \& Rohrmann, 1991). O transcriptoma da infecção de $A c \mathrm{MNPV}$ revelou que este gene é expresso nas primeiras $6 \mathrm{~h}$ iniciais e sua transcrição mantêm-se ativa até $48 \mathrm{~h}$ p.i. em níveis inferiores aos promotores tardios (Chen et al, 2013).

O que foi constatado nos experimentos invariavelmente é que este promotor gênico é otimizado para expressão rápida e intensa pela RNA pol II do hospedeiro logo após o desnudamento do vírion no núcleo da célula. Todas as células analisadas nesse trabalho, permissivas ou não, foram capazes de ativar este promotor.

Algumas observações feitas anteriormente pelo nosso grupo de trabalho, avaliando a presença do mRNA de iel do $A g \mathrm{MNPV}$, sugeriram que a expressão do gene iel é reduzida ou desligada em momentos tardios da infecção ( > 24 h p.i., Pinedo, 2004). Este fenômeno não foi observado nestes experimentos, pois o nível de luminescência permanece alto até 6 dias p.i.. Além disto, o transcriptoma de AcMNPV também confirma a estabilidade na transcrição de iel (Chen et al, 2013). Pouco é conhecido sobre a vida média do mRNA durante a infecção viral, portanto não é possível assumir alguma posição referente à estabilidade do mRNA de fluc. É possível que a proteína FLUC seja estável o 
suficiente ao longo do tempo medido e mesmo com uma redução na transcrição o nível de luminescência permanece, o que pode ser diferente do que ocorre com o mRNA e a proteína IE1.

Como o elemento prAgIE1 não funcionou corretamente, não foi possível comparar diretamente os promotores de $A g \mathrm{MNPV}$ e $A c \mathrm{MNPV}$ durante as infecções com os bacmídeos construídos. Estes promotores possuem similaridade média entre si a nível de sequência (66\%) mas compartilham os motivos de transcrição já definidos como funcionais em $A c \mathrm{MNPV}$ (Figura 25).

\subsubsection{GP64}

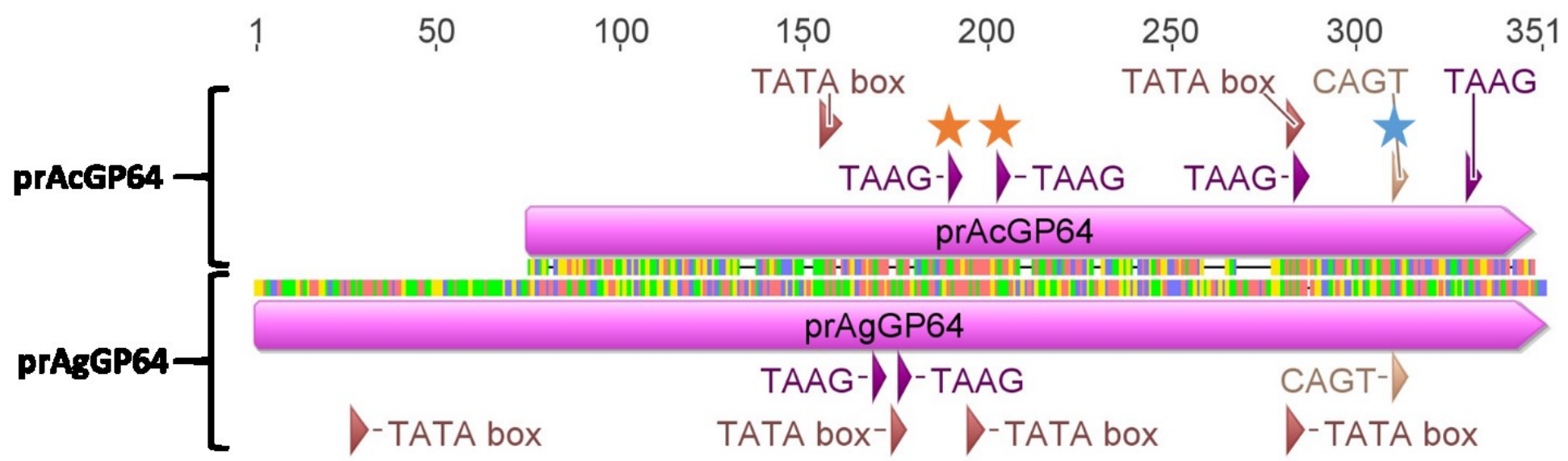

Figura 26: Alinhamento dos promotores GP64 de AcMNPV e AgMNPV. As coordenadas das sequências estão acima. As coordenadas das sequências estão acima. As sequências estão apresentadas em cores modo Clustal. Os motivos de transcrição foram identificados apropriadamente. Os sítios de início de transcrição exatos do promotor de AcMNPV estão apontados na sequência com a estrela azul para transcritos de momentos precoces e estela laranja em transcritos de momentos tardios, conforme descrito em (Chen et al., 2013).

A proteína do envelope viral responsável pela entrada do vírus através da fusão das membranas do vírus e da membrana da célula hospedeira é a proteína de $64 \mathrm{kDa}$ denominada GP64. Dentro do grupo filogenético dos Alphabaculovirus Grupo I, a proteína GP64 é a mais importante para realizar a fusão de membranas e garantir a entrada do vírus na célula e sua propagação dentro do inseto hospedeiro (Rohrmann, 2013). Esta proteína é expressa em momentos precoces e tardios da infecção por $O p M N P V$ (Blissard \& Rohrmann, 1991) e $A c \mathrm{MNPV}$ (Chen et al, 2013), é destinada à membrana plasmática 
onde fica ancorada até o egresso de partículas virais. O contato destas partículas com a face interna da membrana plasmática coberta de GP64 induz o brotamento da partícula viral em uma vesícula para o exterior da célula, formando a partícula viral madura denominada de BV.

Como o início da formação de BVs ocorre nos momentos logo após a replicação do genoma viral até a fase muito tardia, quando os vírions ficam retidos no núcleo para a formação dos ODVs e inclusão nos corpos de oclusão. É razoável assumir que a expressão da proteína GP64 deve ocorrer em momentos precoces, em preparo à migração dos vírions na fase tardia, exatamente o que foi observado neste trabalho. Corroborando esta concepção, a substituição do promotor de GP64 original por um promotor tardio já foi realizado e induziu uma reduzida produção de BVs (Washburn et al., 2003).

Alguns estudos com promotores GP64 de diferentes baculovírus apresentaram resultados conflitantes referente ao momento exato de ativação. Alguns argumentaram que a expressão é precoce atrasada ( $A c \mathrm{MNPV}$, Jarvis \& Garcia, 1994) enquanto outros argumentaram que o promotor é imediatamente precoce $(O p \mathrm{MNPV}$, Blissard \& Rohrmann, 1989, 1991), ambos concordando em relação à classificação como tardios (Garrity et al, 1997). Estas diferenças podem refletir uma seleção diferencial no promotor GP64 entre diferentes baculovírus buscando otimizar a infecção sistêmica através do controle da expressão deste gene essencial ao fenótipo BV.

Com base nos experimentos realizados, podemos afirmar que prAgGP64 é um promotor imediatamente precoce muito similar ao prAgIE1, tanto nas infecções de vAgGP64FLUC quanto BACAgGP64FLUC. O promotor prAcGP64 por outro lado apresentou um perfil mais atrasado de ativação gênica na fase precoce ( $\mathrm{T}_{\text {in }}>2 \mathrm{~h}$ p.i., Tabela 5), muito distinto do observado para o prAgGP64 ( $\mathrm{T}_{\text {in }}<2$ h p.i., Tabela 5). 
Esta ativação em momentos imediatamente precoces de prGP64 também está de acordo com a hipótese de que os multiple nucleopolyhedrovirus (MNPV), que são oclusos em envelopes com múltiplas partículas virais em momentos muito tardios, possuem uma vantagem sobre os single nucleopolyhedrovirus (SNPV) para atravessar o intestino dos hospedeiros de forma acelerada. Os ODVs dos MNPVs, como o AcMNPV e o AgMNPV, são responsáveis pela infecção primária em células epiteliais do intestino de larvas suscetíveis e costumam entregar a célula um agregado de 6 virions em média, gerando um tipo de superinfecção (Rohrmann, 2013). A rápida expressão de gp64 em momentos imediatamente precoces permite que alguns destes virions retidos no citoplasma, derivados da infecção primária que não foram dirigidos ao núcleo, brotem para fora da célula através da proteína GP64 recém sintetizada e iniciem a infecção sistêmica antes da replicação viral ocorrer. Esta habilidade garante uma rápida proliferação do vírus ao escapar das defesas inatas destas células, que naturalmente possuem curto período de vida e podem ser descamadas antes do vírus se proliferar.

A ativação do elemento tardio em prAgGP64 foi observado no aumento da expressão após 12 h p.i. durante as infecções nas linhagens permissivas UFLAg, Tn5B e de forma mais nítida em Tn5B tratada com afidicolina e infectada com vAgGP64FLUC (Figura 13). Na qual, após a reversão da inibição, aumenta consideravelmente a expressão. Este padrão bifásico com expressão precoce e aumento substancial durante a fase tardia já foi observado durante a infecção celular pelo promotor gênico de gp64 do baculovírus AcMNPV (Jarvis \& Garcia, 1994; Garrity et al., 1997) e foi bem caracterizado durante as infecções com vAgGP64FLUC e BACAgGP64FLUC. Ironicamente, a sequência de prAgGP64 e prAcGP64 são bem distintas (58\% de identidade) e prAgGP64 não possui os sítios de início de transcrição da fase tardia mapeados pelo transcriptoma de AcMNPV (Chen et al., 2013) mas possuem dois INR 
TAAG em posições distintas que claramente são ativados de forma eficiente (Figura 26).

A expressão mais consistente na fase imediatamente precoce de prAgGP64 é um forte indício de que este promotor é mais eficiente que prAcGP64.

\subsubsection{LEF1}

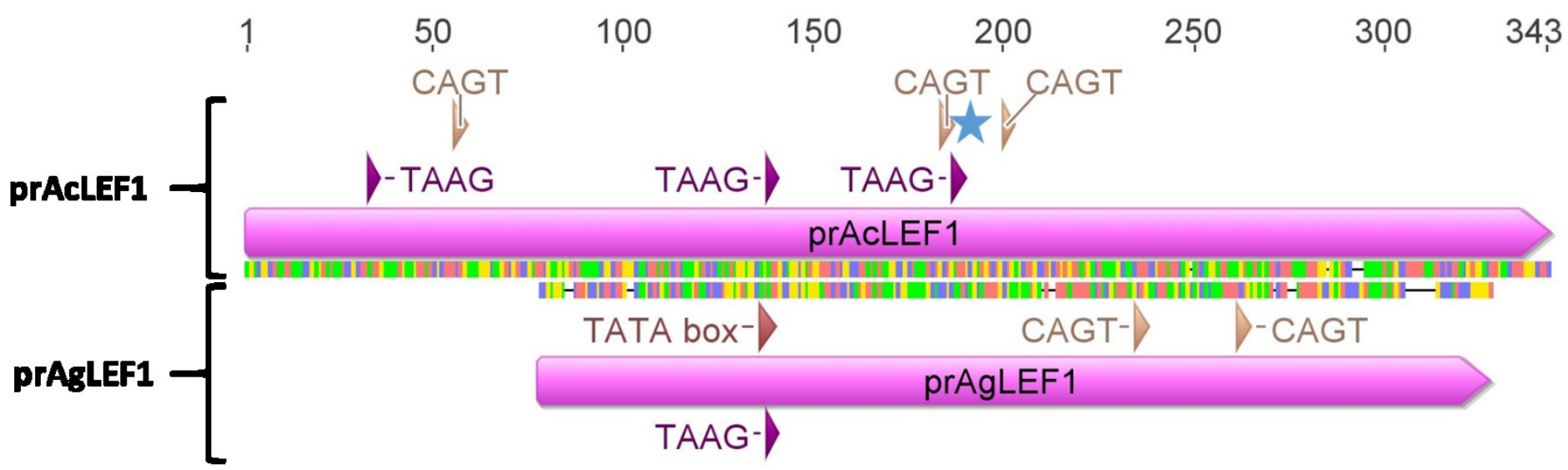

Figura 27: Alinhamento dos promotores LEF1 de AcMNPV e AgMNPV. As coordenadas das sequências estão acima. As coordenadas das sequências estão acima. As sequências estão apresentadas em cores modo Clustal. Os motivos de transcrição foram identificados apropriadamente. Os sítios de início de transcrição em momentos precoces do promotor de AcMNPV estão apontados na sequência com a estrela azul, conforme descrito em (Chen et al., 2013).

A DNA polimerase viral dos baculovírus é um complexo protéico formado pelos produtos dos genes DNA pol (DNA polimerase viral), helicase, lefl (primase), lef2 (fator acessório de primase), lef3 (single stranded DNA binding protein) e o gene ie1 (Rohrmann, 2013). Estes elementos em conjunto são responsáveis pela replicação do DNA viral durante a infecção celular. A atividade de primase da proteína LEF1 é essencial na geração de primers de RNA que auxiliam na extensão da fita de DNA durante a replicação (Passarelli \& Miller, 1993).

Não existem estudos focados na expressão deste gene (lef1), ou mesmo dos demais genes associados à DNA pol viral. Este trabalho apresenta o primeiro estudo específico com este promotor. O transcriptoma de $A c \mathrm{MNPV}$ em Tn5B (Chen et al, 2013) indica que a transcrição desse gene é detectada as $6 \mathrm{~h}$ p.i. e sua transcrição é baixa em relação aos genes iel e aos demais genes tardios de alta expressão, o que é muito similar 
ao observado nestes experimentos. No entanto, não existem intervalos de medição entre 0 e 6 h p.i. nos dados do transcriptoma para estimar com precisão o início da transcrição deste gene e assim classificá-lo como imediatamente precoce ou precoce atrasado. As infecções com o vírus vAgLEF1FLUC detalharam com precisão a ativação deste promotor durante as primeiras 6 h p.i. e sua fraca expressão (Figuras 9 e 10). Por outro lado, as infecções com os $A c \mathrm{MNPV}$ recombinantes contendo tanto pr $A g \mathrm{LEF} 1$ quanto prAcLEF1 apresentaram perfis muito mais atrasados de ativação, com $\mathrm{T}_{\text {in }}>6 \mathrm{~h}$ p.i. (Tabela 5, Figuras 23 e 24). Este atraso observado para ambos promotores pode estar mais relacionado a uma característica do baculovírus $A c \mathrm{MNPV}$ do que em relação às distinções nas sequências dos promotores. Estes promotores são bastante distintos entre si dentro do set de promotores isolados com $61.7 \%$ de identidade a nível de sequência (Figura 27). Os 2 elementos INR da fase precoce CAGT mapeados como sítios de início de transcrição em $A c$ MNPV (Chen et al., 2013) não são conservados no vírus $A g M N P V$ que também possui 2 elementos CAGT mas em posições completamente distintas. Outro ponto interessante, é que tanto prAgLEF1 quanto prAcLEF1 possuem elementos TAAG que claramente não são ativados na fase tardia.

A expressão em momentos precoces da infecção é essencial para garantir que a replicação do DNA ocorra rapidamente mas a expressão não é alta e os níveis de luminescência indicam que esta proteína não deve estar presente em grande quantidade para que a replicação ocorra adequadamente. Isto pode ser extendido aos demais genes associados à replicação, transcritos em baixas quantidades iniciando em momentos precoces se utilizarmos como base o transcriptoma da infecção de $A c \mathrm{MNPV}$ (Chen et al, 2013). 
2.5.4. VP39

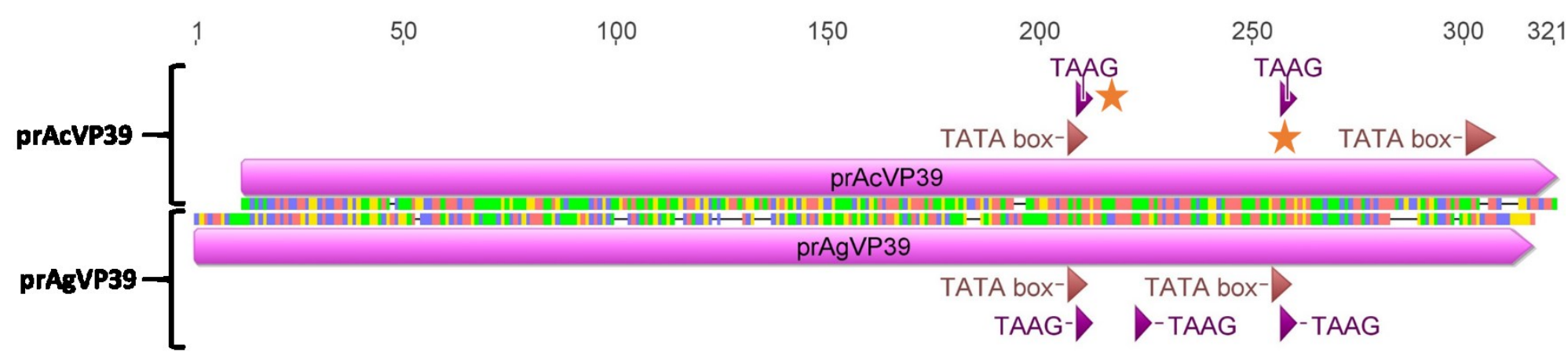

Figura 28: Alinhamento dos promotores VP39 de AcMNPV e AgMNPV. As coordenadas das sequências estão acima. As coordenadas das sequências estão acima. As sequências estão apresentadas em cores modo Clustal. Os motivos de transcrição foram identificados apropriadamente. Os sítios de início de transcrição exatos do promotor de AcMNPV estão apontados na sequência com a estrela laranja para transcritos de momentos tardios, conforme descrito em (Chen et al., 2013).

O gene vp39 codifica a proteína principal do capsídeo viral, com massa molecular de 42 kDa (Russel et al., 1991). No núcleo, a proteína VP39 forma aglomerados em um padrão reticular e estes focos estão sempre associados à presença de DNA viral (Kawasaki et al., 2004). Desta forma, a proteína VP39 auxilia a formar o estroma virogênico. Quando o nucleocapsídeo está maduro, ele deve trafegar do núcleo para a face interna da membrana plasmática, este trânsito ocorre pela associação entre as proteínas do capsídeo viral e os microtúbulos periféricos do citoesqueleto da célula (Danquah et al., 2012).

Originalmente caracterizado como promotor da fase tardia (Morris \& Miller, 1994), devido à falta de elementos INR da fase precoce em sua sequência e a presença de múltiplos elementos INR da fase tardia. O gene $v p 39$ não é transativado pela proteína IE1 sozinha ou é auxiliado em cis por regiões homólogas (Ribeiro et al., 1994; Ishiyama \& Ikeda, 2010). Existem relatos de atividade na fase precoce do promotor VP39 do baculovírus AcMNPV (Theilmann \& Stewart, 1991), no entanto, este promotor é comumente referido como exclusivamente tardio (Rohrmann, 2013). O transcriptoma do $A c \mathrm{MNPV}$ não detectou mRNA deste gene as $6 \mathrm{~h}$ p.i. (o limiar final da fase precoce) mas detecta altos níveis de transcrição as $12 \mathrm{~h}$ p.i. e o classifica apenas como tardio (Chen et al, 2013), distinto das observações de que prAgVP39 possui atividade em momentos 
precoces atrasados, claramente detectados durante as infecções com o recombinante vAgVP39FLUC (Figuras 9 e 10).

Neste trabalho, observamos a atividade em momentos precoces atrasados deste promotor, classificando pr $A g \mathrm{VP} 39$ como precoce atrasado e tardio, o que é consistente com a necessidade da colocalização da proteína VP39 com IE1 e o DNA viral em momentos prévios à replicação, iniciando a formação do estroma virogênico. Isto está em conflito com o observado para o promotor equivalente em $A c \mathrm{MNPV}$, sem a capacidade de expressão em momento precoces atrasados. Os promotores VP39 de ambos vírus possuem alta identidade a nível de sequência $(87 \%)$ nos 100 pb imediatamente a montante ao códon de iniciação da proteína (Figura 28). As diferenças mais importantes ocorrem em prAgVP39, que contém um elemento TATA box a mais, que está sobreposto ao INR tardio TAAG (5'-TA $\underline{T A A \mathrm{G}}-3^{\prime}$ em $A g \mathrm{MNPV}, 5^{\prime}$-AATAAG-3' em $\left.A c \mathrm{MNPV}\right)$ mais próximo ao códon de iniciação e um elemento TAAG extra a -30 pb do INR tardio citado acima. Este TATA box extra poderia explicar a expressão precoce atrasada observada nas infecções com o $A g \mathrm{MNPV}$ pois este elemento é essencial na expressão da fase precoce (Chen et al., 2013). No entanto, não explica (de fato complica) a falta de expressão em momentos precoces durante a infecção do vírus recombinante BACAgVP39FLUC em células permissivas (Figura 23).

\subsubsection{P6.9}

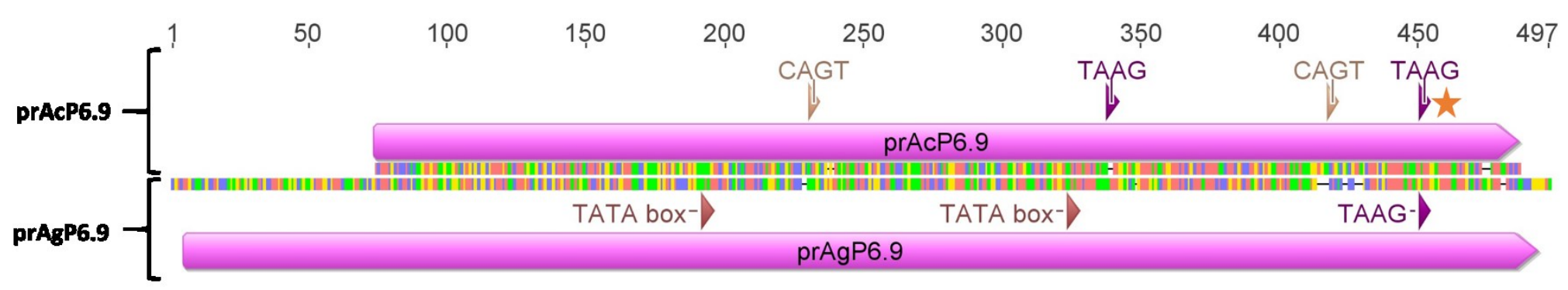

Figura 29: Alinhamento dos promotores P6.9 de AcMNPV e AgMNPV. As coordenadas das sequências estão acima. As coordenadas das sequências estão acima. As sequências estão apresentadas em cores modo Clustal. Os motivos de transcrição foram identificados apropriadamente. Os sítios de início de transcrição exatos do promotor de AcMNPV estão apontados na sequência com a estrela laranja para transcritos de momentos tardios, conforme descrito em (Chen et al., 2013). 
A proteína P6.9 é encontrada associada ao DNA viral, no interior dos nucleocapsídeos (Tweeten et al., 1980), e associada ao estroma virogênico no núcleo da célula infectada após a replicação (Wilson et al., 1987, 1988; Peng et al., 2012). É uma proteína conservada entre os Alpha e Betabaculovirus com tamanho pequeno (44 aa, 6.9 $\mathrm{kDa}$ ), rico em arginina (40\%), serina e treonina, devido à isto é descrita como a proteína "básica" (Rohrmann, 2013). O aminoácido arginina possui alta afinidade pelo esqueleto de fosfato na estrutura do DNA, estes resíduos neutralizam a carga do DNA, enquanto que os resíduos de treonina e serina interagem para manter a carga total neutra do complexo, permitindo a manutenção de uma estrutura DNA-proteína supercondensada e compacta (Wilson et al., 1987).

A função da proteína P6.9 em baculovírus é a condensação do DNA viral para o empacotamento deste nos capsídeos em formação no estroma virogênico. Esta proteína e VP39 são essenciais em grandes quantidades no núcleo para induzir a formação de abundantes quantidades de vírions. Os promotores de ambas proteínas são os mais ativos nas infecções de células permissivas, tanto pelo $A g \mathrm{MNPV}$ quanto pelo $A c \mathrm{MNPV}$. Enquanto as células semipermissivas e não-permissivas, caracterizadas exatamente por uma reduzida ou nula formação de um dos fenótipos infectivos, não hiperativam estes promotores. O transcriptoma de $A c \mathrm{MNPV}$ revelou que este gene tem uma transcrição considerada naquele trabalho como precoce às $6 \mathrm{~h}$ p.i. e a partir de $12 \mathrm{~h}$ p.i. é um dos genes com maior transcrição (Chen et al, 2013). O que observamos aqui foi que a ativação do promotor ocorre a partir de 8 h p.i., seja pelas infecções com AcMNPV (Figuras 23 e 24) ou AgMNPV recombinantes (Figuras 9 e 10). A transcrição certamente deve ocorrer antes da tradução, portanto, faz sentido detectar a proteína repórter após a detecção dos transcritos relevantes. A nível de sequência, tanto prAcP6.9 quanto prAgP6.9 não possuem elementos canônicos da fase precoce (Figura 29), portanto não espera-se 
detectar proteínas a partir destes promotores em momentos precoces, o que foi confirmado experimentalmente.

\subsubsection{POLH}

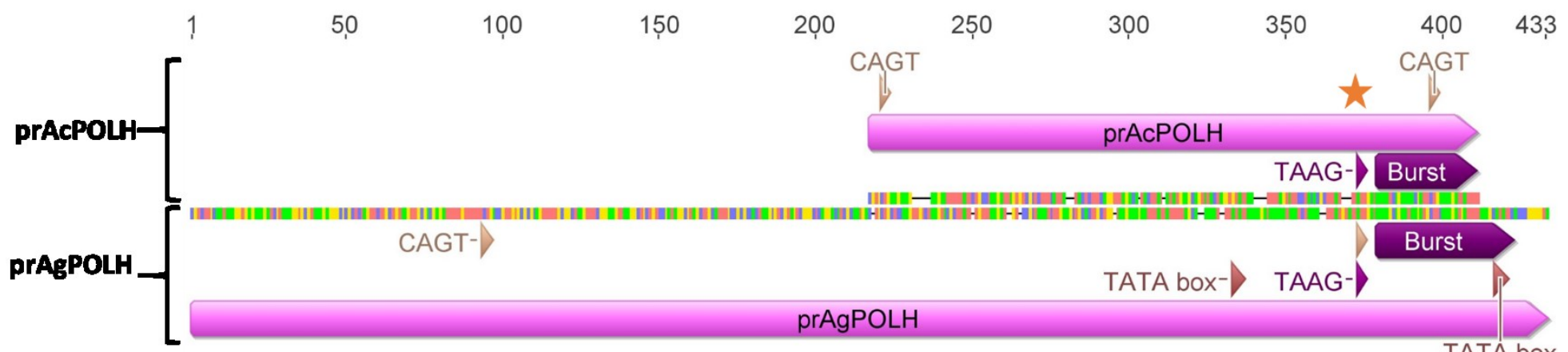

Figura 30: Alinhamento dos promotores POLH de AcMNPV e AgMNPV. As coordenadas das sequências estão acima. As coordenadas das sequências estão acima. As sequências estão apresentadas em cores modo Clustal. Os motivos de transcrição foram identificados apropriadamente. Os sítios de início de transcrição exatos do promotor de AcMNPV estão apontados na sequência com a estrela laranja para transcritos de momentos tardios, conforme descrito em (Chen et al., 2013).

O gene polh evoluiu duas funções altamente especializadas. A proteína POLH (29 kDa) é o principal componente (95\%) do cristal protetivo que forma os corpos de oclusão, além disto, a estrutura dos OBs garante proteção aos vírions no meio ambiente. Entretanto, quando expostos a um ambiente alcalino e redutor, similar ao encontrado no intestino médio das larvas de Lepidoptera, os OBs são facilmente solubilizados (Leisy et al., 1986). Estas duas propriedades, a oclusão de partículas virais e a solubilização apenas no intestino de larvas hospedeiras, garantem a forma viável do vírus fora do hospedeiro.

O promotor da poliedrina é o promotor baculoviral mais estudado e utilizado quando discutimos expressão de proteínas em células de inseto ou larvas, devido à sua intensidade de expressão em momentos muito tardios da infecção. Em $A c \mathrm{MNPV}$, prPOLH é classificado como muito tardio, contendo motivo tardio TAAG e um elemento de ativação downstream (DAR) chamado de sequência burst, localizado na região 5 ' não traduzida do mRNA que se inicia no INR de fase tardia. Em $A c \mathrm{MNPV}$, o elemento INR de fase tardia ocorre a -52 pb a montante do primeiro codon da ORF POLH (Figura 30). A deleção da região -52 a -1 pb resulta em redução quase total dos níveis de expressão do 
promotor. A sequência até -92 pb é considerada o núcleo do promotor, isto é, deleção de regiões além a -92 pb não afetam a atividade de transcrição ou recrutamento da RNA pol viral (Rankin et al., 1988).

O elemento DAR de prPOLH (sequência burst) é importante para garantir a hipertranscrição do gene em momentos muito tardios da infecção. O gene very late factor $l(v l f-1)$, transativador de promotores da fase muito tardia, codifica a proteína VLF-1, que interage com a sequência burst, estimulando a expressão dos promotores muito tardios (Yang \& Miller, 1999; Todd et al., 1996). A repetição in tandem desta sequência burst a jusante do INR resulta em um prPOLH modificado ainda mais eficiente (Kato et al., 2012). O transcriptoma de $A c \mathrm{MNPV}$ indicou que este gene é transcrito a partir de $12 \mathrm{~h}$ p.i., sendo o mais abundante a partir de 24 h p.i. (Chen et al, 2013). Neste trabalho, as infecções com vAgPOLHFLUC inicia sua expressão a partir de 9 h p.i. e não é capaz de induzir luminescência maior que prAgVP39 e prAgP6.9 (Figuras 9 e 10). As infecções com o recombinante de $A c \mathrm{MNPV}$ contendo o elemento prAgPOLH foram similares em termos de intensidade reduzida mas o tempo de ativação foi muito distinto (Tabela 5), iniciando a expressão no mesmo momento que os promotores tardios VP39 e P6.9 de ambos baculovírus.

Estas diferenças em expressão entre promotores tardios e muito tardios podem corresponder à diferenças nas sequências destes promotores que são similares apenas nos -52 pb da posição até o início da ORF polh. Upstream à esta região, os promotores são totalmente distintos. É importante notar que o AgMNPV possui uma inversão do locus do gene polh em relação a $A c \mathrm{MNPV}$ o que pode explicar parcialmente estas diferenças.

Nestes experimentos, observamos consistentemente uma diferença em $\mathrm{T}_{\text {in }}$ entre o promotor tardio prAgP6.9 e muito tardio prAgPOLH durante as infecções com os AgMNPVs recombinantes. Considerando que POLH agrega-se formando cristais ao 
acumular no núcleo e através disto captura os vírions ali formados, uma expressão acentuada em momentos precoces poderia reduzir a habilidade dos vírions de sair do núcleo e trafegar até a membrana, afetando a formação do primeiro fenótipo BV que é essencial à infecção sistêmica. A partir disto, podemos formular como hipótese que o atraso de poucas horas na ativação deste promotor favorece a formação de BVs de forma temporária até que POLH acumule em níveis consideráveis no núcleo e capture os vírions.

Um experimento que pode testar esta hipótese seria a construção de baculovírus recombinantes contendo prIE1, prVP39 e o próprio prPOLH regulando a proteína POLH. Se a produção de POLH e formação de poliedros tiver como efeito a captura dos vírions formados no núcleo, observaremos redução na produção de BVs. De qualquer forma, é difícil explicar como ocorre este atraso, pois o prPOLH possui elementos de transcrição tardios muito similares a prP6.9 e prVP39 (basicamente a presença de INR TAAG). Até o momento, nenhum tipo de elementos cis ou trans que atue como repressor da transcrição gênica foi encontrado na biologia dos baculovírus.

\subsection{Os baculovírus $A c M N P V$ e $A g M N P V$ possuem perfis de expressão similares}

Este trabalho realizou a primeira comparação direta de um grupo de promotores gênicos com seus homólogos de outra espécie viral dentro do mesmo sistema de expressão e entre dois sistemas distintos. A conclusão fundamental é que nas linhagens permissivas os perfis de expressão gênica entre os dois baculovírus $A g \mathrm{MNPV}$ e $A c \mathrm{MNPV}$ são muito similares. A sequência de ativação gênica, o momento em que o pico de expressão é atingido e as proporções relativas de expressão dos promotores tardios e precoces são mais consistentes entre diferentes linhagens nas infecções pelo $A g M N P V$, no entanto o $A c \mathrm{MNPV}$ seguiu relativamente o mesmo padrão. Os promotores derivados de $A g \mathrm{MNPV}$ também funcionaram de forma praticamente idêntica aos de $A c \mathrm{MNPV}$ 
quando clonados no sistema BAC-to-BAC que usa o AcMNPV como base, mesmo infectando linhagens celulares de permissividade limitada. Isto tem duas grandes implicações que podem funcionar em conjunto: primeiro que o mecanismo de ação destes promotores necessariamente são conservados para poder manter o programa de transcrição baculoviral durante a infecção e segundo que estes dois baculovírus possuem espectros de hospedeiros que se sobrepõe. Isto é confirmado também pela pequena distância filogenética relativa entre os dois vírus pois ambos são Alfabaculovírus MNPVs do grupo I (Jehle et al., 2006) apesar de serem de subgrupos distintos (Oliveira et al., 2006).

Mesmo com alta similaridade, algumas diferenças devem ser levadas em consideração. Durante as infecções com os $A c \mathrm{MNPVs}$, os elementos precoces do promotor bimodal VP39 e o promotor precoce-atrasado LEF1 não foram ativados dentro das primeiras 6 h como ocorreu durante a infecção com $A g M N P V$. Isto é potencialmente uma característica do baculovírus $A c \mathrm{MNPV}$ que pode possuir uma eficiência de expressão inferior ao vírus $A g \mathrm{MNPV}$ durante a fase precoce da infecção. O promotor precoce-atrasado prLEF1 tanto de $A g$ quanto $A c \mathrm{MNPV}$ também se comportou de forma similar, com atraso significativo na ativação, possivelmente relacionado à fraca expressão.

A maior diferença nos perfis de expressão entre infecções do $A g \mathrm{MNPV}$ e AcMNPV ocorre em Bm5 e Chch (Figura 10 e 24). O vírus $A c \mathrm{MNPV}$ foi capaz de expressar fracamente os promotores tardios VP39 e P6.9 tanto de AcMNPV quanto AgMNPV (Figura 24). Na linhagem Ld652Y ocorreu leve expressão a partir de prAgPOLH. Nenhum destes perfis foram observados durante as infecções com os AgMNPV recombinantes (Figura 10). 
Outra diferença observada entre os dois vírus ocorreu na linhagem Chch em que os níveis de expressão do vírus $A c \mathrm{MNPV}$ foram 100 vezes menores que os observados na infecção com $A g \mathrm{MNPV}$. Ambos os vírus causam apoptose nesta linhagem celular como foi observado por microscopia de luz a partir de 24 h p.i.. Uma das diferenças mais estudadas entre estes dois vírus é que o $A c \mathrm{MNPV}$ utiliza como agente antiapoptótico o gene p35 (Clem \& Miller, 1993) e o AgMNPV utiliza o gene iap3 (Carpes et al., 2005). Estes possuem alvos distintos na via metabólica que induz a apoptose que podem ter impactos distintos sobre a expressão gênica. A alta expressão gênica do vírus $A g \mathrm{MNPV}$ aponta na direção de maior eficiência antiapoptótica do gene iap3. A infecção de células Sf21 com $A c$ MNPV contendo o gene $p 35$ deletado foi caracterizada como abortiva, com atraso na expressão gênica precoce e tardia. Além de não ter sido detectada nenhuma expressão de genes muito tardios mas sim uma inibição da síntese protéica em momentos tardios do processo apoptótico (Clem \& Miller, 1993). Desta forma, a apoptose torna-se uma defesa muito eficiente para eliminar a formação de OBs ao afetar a expressão muito tardia. Por outro lado, não inibe completamente a formação do primeiro fenótipo, os BVs.

Em Bm5 ambos baculovírus possuem um perfil de expressão similar com expressão de prIE1 e prGP64 mas bloqueio na expressão dos promotores tardios (Figura 10). Apenas na infecção com o $A c \mathrm{MNPV}$ ocorreu uma leve ativação dos promotores tardios VP39 e GP64, mas muito próximo ao sinal basal de luminescência (Figura 24).

As diferenças mais significantes no perfil de expressão entre os baculovírus $A g \mathrm{MNPV}$ e $A c \mathrm{MNPV}$ recombinantes foram encontradas durante a infecção em células consideradas não-permissivas. Nestes sistemas, os genes associados ao controle celular específico de cada baculovírus tornam-se mais importantes e seus efeitos podem ser avaliados com base no perfil de expressão comparado. 


\subsection{O perfil de expressão dos promotores de genes não encapsidados de $M d B V$ durante infecções com os $A c$ MNPV recombinantes em linhagens celulares permissivas}

A escolha dos promotores a serem isolados do $M d \mathrm{BV}$ levou em conta a presença dos motivos de transcrição similar a baculovírus dentro de 300 pb a montante da sequência codificadora dos genes com maior expressão de acordo com o transcriptoma feito nesta espécie (Barat-Houari et al., 2006; Burke \& Strand, 2014; Chevignon et al., 2014; Weber et al., 2007).

Utilizando os plasmídeos pFAST contendo os promotores de $M d \mathrm{BV}$, células DH10BAC foram transformadas e as colônias positivas foram selecionadas por PCR, utilizando os primers universais M13 e um primer anti-senso em relação a cada promotor $M d \mathrm{BV}$. Os resultados das PCRs (Figura 31) demonstraram que os promotores estão presentes dentro do genoma recombinante para cada transformação realizada. O controle negativo mostra a amplificação de um fragmento de 300 pb a partir do DNA de um bacmídeo em que não ocorreu transposição. A colônia do vírus BACMdO64FLUC também apresentou a banda negativa de 300 pb, indicando que a colônia coletada não estava completamente pura. Após replaquear a mesma colônia por espalhamento, uma outra extração de DNA foi realizada com uma colônia que não apresentou esta banda (dado não mostrado). Os DNAs derivados das colônias foram então transfectados em células de inseto assim gerando os vírus recombinantes. 


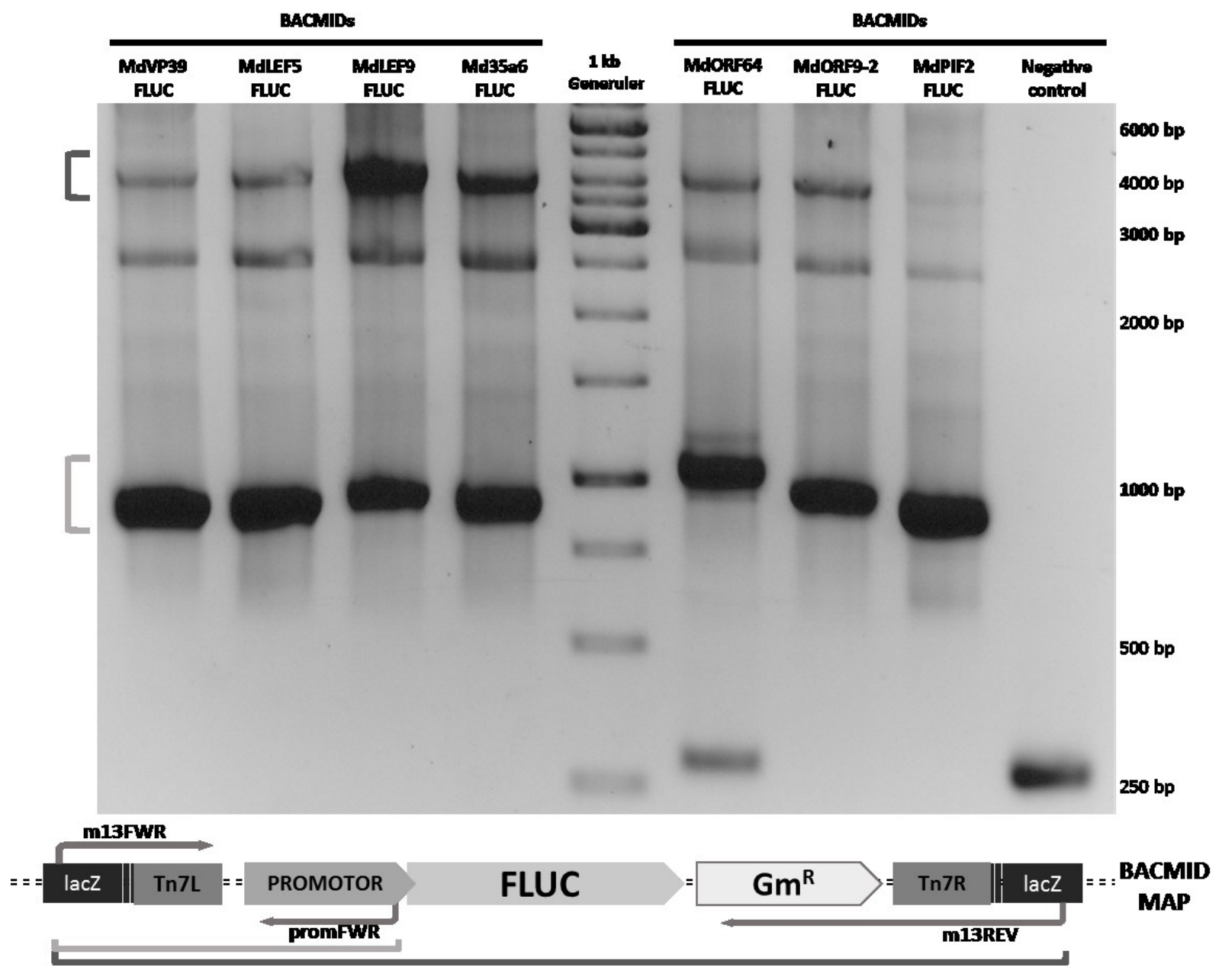

Figura 31: Confirmação da clonagem dos diferentes promotores de $M d B V$ comandando o gene fluc no bacmídeo de $A c M N P V$. Gel de agarose $\mathbf{0 . 8 \%}$ mostrando os resultados de PCR utilizando os primers universais M13 e um primer antisenso em relação a cada promotor. A amplificação de uma banda de aproximadamente $4500 \mathrm{pb}$ indica a correta transposição dos promotores e gene FLUC para dentro do DNA dos bacmídeos. A amplificação de uma banda próxima a 1000 pb confirma a presença de cada promotor nos bacmídeos. $O$ controle negativo indica a amplificação de um amplicon de $\mathbf{3 0 0}$ pb referente ao gene LacZ intacto, sem ter ocorrido a transposição. 0 marcador de DNA utilizado foi o 1 kb Generuler (Fermentas).

Poucos estudos foram realizados buscando compreender a atividade de promotores de genes encapsidados de PDVs. No entanto, nenhum estudo foi realizado até o momento com os genes não-encapsidados. Os estudos que testaram a atividade dos promotores de genes encapsidados em larvas Lepidoptera indicaram rápida ativação, dentro de 4 h após a transfecção, e forte expressão (Asgari \& Schmidt, 2001; Soldevila \& Webb, 1996). Estes promotores gênicos utilizam a RNA pol II do hospedeiro Lepidoptera de forma similar aos genes imediatamente precoces dos baculovírus (Soldevila \& Webb, 1996). Ensaios de deleção do promotor de um gene de Campoletis 
sonorensis polydnavirus (CsPDV) indicaram que apenas o elemento TATA box era crucial para que o promotor fosse ativado em células da hemolinfa extraídas de larvas Heliothis virescens, que são suscetíveis ao parasitismo de C. sonorensis e seu CsPDV endógeno (Webb \& Cuit, 1997). Ainda não existe um transcriptoma feito por RACE 5' para pontuar com precisão o início de transcrição, no entanto, a única observação consistente realizada até o momento com as técnicas de sequenciamento em massa é que os elementos TATA box são os mais consistentemente observados próximos do início dos mRNAs detectados (Chevignon et al., 2014).

A relação entre Nudivirus, Baculovírus e PoliDNAvírus levanta a questão referente a transcrição dos genes tardios não-encapsidados (VP39, 35A6, ORF6-4, ORF92 e PIF2). Se mesmo com a pressão seletiva remodelando os segmentos virais para ficarem mais "parecidos" com os genes da vespa, isto é: genes que sofrem splicing, promotores com grandes sequências e grande espaço intergênico (Burke et al., 2016, 2014, 2013). Seria possível que o mecanismo ancestral associado a RNA polimerase viral dos Nudivírus e a hiperexpressão gênica promovida ainda permaneça conservado entre Baculovírus e os PDVs?

Como observado nos ensaios de medição de luminescência por lise a 48 h p.i. das infecções com os bacmídeos contendo promotores de $M d \mathrm{BV}$, a linhagem Tn5B foi capaz de expressar o gene repórter a partir dos diversos promotores de $M d \mathrm{BV}$ com diferentes intensidades. Para determinar com maior precisão os tempos de início e pico de expressão gênica e assim ter melhor referência para determinar o tipo de cada promotor no contexto da infecção pelos baculovírus foram realizados experimentos de medição de luminescência em tempo real das infecções em duas linhagens suscetíveis ao $A c \mathrm{MNPV}$, Tn5B e Sf9. A figura 32 apresenta as curvas de expressão gênica e a tabela 6 contém os valores de $\mathrm{T}_{\text {in }}$ a partir dos diversos promotores isolados de $M d \mathrm{BV}$. 
Uma surpreendente observação em comum para todos os promotores em ambas as células é que o tempo de primeira detecção ocorreu em momentos considerados tardios ( $>8 \mathrm{~h}$ em Tn5B e $>12 \mathrm{~h}$ p.i.). Os promotores $M d$ LEF5 e $M d$ LEF9, por exemplo, possuem promotores precoces canônicos, contendo INR CAGT e TATA box associado, portanto a expectativa era de que estes promotores fossem ativados dentro das primeiras $5 \mathrm{~h}$ de infecção o que não foi observado em nenhuma das duas linhagens testadas, indicando que as linhagens derivadas de Lepidoptera são incapazes de reconhecer estes motivos de transcrição precoces.

Os promotores com elementos de transcrição tardios MdLEF9, MdORF64 e MdORF9-2 apresentaram os maiores sinais de luminescência em ambas linhagens, com pico de expressão em níveis de $4 \times 10^{3}$ RLU. O segundo patamar de luminescência ocorreu com os promotores MdVP39, MdLEF5 e Md35a6 em níveis de 1 x $10^{3}$ RLU. Existe uma diferença significativa entre os dois patamares (teste $t, p<0.0001$ entre $V_{\max }$ de $\operatorname{prMdLEF9~e~prMdVP39).~O~promotor~} M d \mathrm{PIF} 2$ apresentou um sinal retardado $\left(\mathrm{T}_{\text {in }}=\right.$ 14 h em Tn5B e 19 h em Sf9) e fraca luminescência ( 2 x 10² RLU), características que estão em contraponto com a presença de um elemento INR tardio neste promotor. 

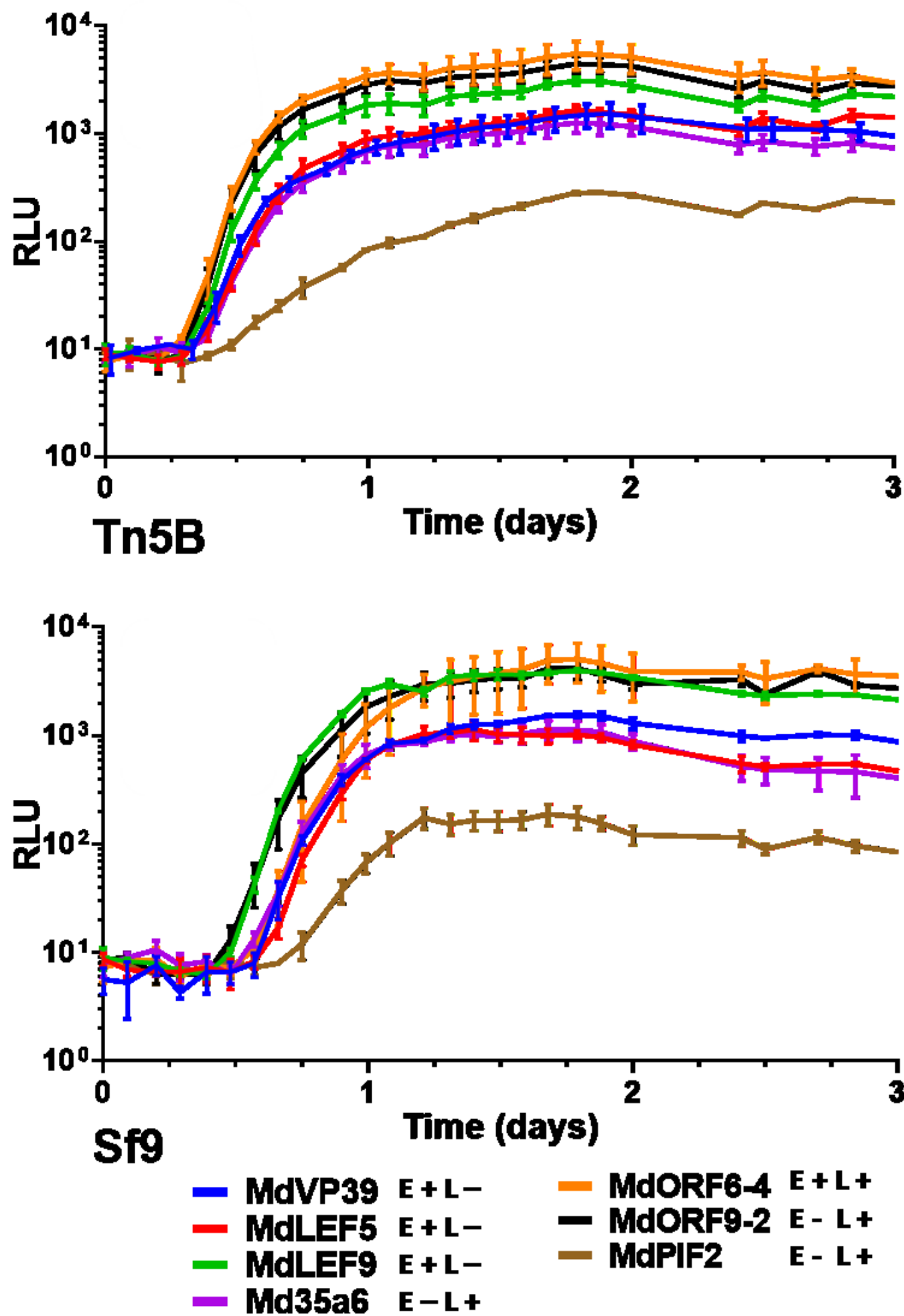

Figura 32: Ensaio de medição contínua de luminescência da infecção das linhagens de Lepidoptera Tn5B e Sf9 com os baculovírus recombinantes AcMNPV contendo os promotores derivados de $M d B V$ ao longo de 3 dias de infecção. As linhas representam as médias de triplicatas e as barras de erro os desvios em relação à média. $\mathrm{Na}$ legenda estão destacadas a presença ou ausência (+ , -) de motivos da fase early (E) ou precoce (TATA box e/ou INR CAGT) e late (L) ou tardia (INR TAAG), comumente encontrados em promotores de baculovírus. 
Outra observação interessante é que a linhagem Sf9 apresentou um retardo consistente (pelo menos $3 \mathrm{~h}$ ) na ativação dos promotores de $M d \mathrm{BV}$ em relação a linhagem Tn5B (Tabela 6). Isto pode ser uma propriedade inerente ao metabolismo da linhagem Sf9 em comparação à Tn5B, como já discutido ateriormente.

Tabela 6: Tempo de primeira detecção $\left(T_{\text {in }}\right)$ do sinal de luminescência (hh:mm), ensaio com células infectadas com os baculovírus AcMNPV recombinantes contendo os promotores derivados de $\mathrm{MdBV}$.

\begin{tabular}{cccccccc}
\hline Linhagem & \multicolumn{7}{c}{ Vírus } \\
\hline & MdVP39 & MdLEF5 & MdLEF9 & Md35a6 & MdO64 & MdO92 & MdPIF2 \\
& Média & Média & Média & Média & Média & Média & Média \\
\hline Tn5B & $9: 40$ & $9: 43$ & $9: 04$ & $10: 04$ & $8: 15$ & $8: 34$ & $14: 15$ \\
Sf9 & $15: 01$ & $16: 01$ & $12: 30$ & $14: 30$ & $14: 49$ & $12: 09$ & $19: 29$ \\
\hline
\end{tabular}

O perfil de expressão dos promotores de $M d \mathrm{BV}$ durante a infecção de células permissivas Tn5B e Sf9 com os baculovírus recombinantes revelou um padrão inesperado. Não foi observada atividade de qualquer um dos promotores em momentos precoces da infecção, o sinal mais antecipado foi do promotor $M d \mathrm{O} 6-4$ as $8 \mathrm{~h}$ p.i. na linhagem Tn5B (Tabela 6). Como já foi indicado nas infecções do $A g M N P V$ e $A c M N P V$, a partir de 8 h p.i. ocorre a ativação de promotores tardios como P6.9 e POLH, além disso, a quantificação do DNA viral de $A g \mathrm{MNPV}$ em Tn5B demonstrou que a partir de $6 \mathrm{~h}$ p.i. inicia a replicação do vírus. Com base nos experimentos de medição de luminescência em tempo real todos os promotores de $M d \mathrm{BV}$ apresentaram um perfil tardio de expressão gênica.

O problema com este perfil de expressão é que os promotores $M d \mathrm{VP} 39, M d \mathrm{LEF} 5$, MdLEF9 e MdO6-4 possuem motivos de transcrição da fase precoce baculoviral, alguns destes como os encontrados em MdLEF5 e MdLEF9 são motivos INR CAGT acompanhados de um motivo TATA box $30 \mathrm{pb}$ a montante do INR, que em conjunto formam um elemento canônico de transcrição eficiente na fase precoce baculoviral. A inatividade destes elementos de transcrição da fase precoce durante a infecção é 
interessante, pois sugere que apenas a presença dos motivos esperados pode não ser suficiente, exigindo um contexto maior para serem reconhecidos pela RNA pol II do hospedeiro. Além disso, os promotores MdLEF5 e $M d$ VP39 não possuem motivos de transcrição tardia TAAG para serem reconhecidos e transcritos na fase tardia, mas atuaram como tardios com base no tempo da detecção.

É possível que o nível de expressão destes em momentos precoces seja extremamente baixo e inferior ao detectável pela técnica, a replicação então teria um efeito positivo sobre a expressão destes promotores supostamente precoces que então se tornam detectáveis. Isto foi confirmado pelos ensaios de transfecção em células Tn5B, em que um fraco sinal de prMdLEF9 e prMdO6-4 foi detectado. Outra opção é que os promotores de $M d \mathrm{BV}$ não são transativados ou são reprimidos pela proteína IE1 de AcMNPV devido a presença de elementos cis contendo a sequência 5'-ACBYGTAA-3' (Leisy et al., 1997), como cogitado no caso do promotor IE1 de $\mathrm{AgMNPV}$ quando clonado no genoma do $A c \mathrm{MNPV}$. No entanto este motivo repressor não ocorre em nenhum dos promotores derivados de $M d \mathrm{BV}$.

O objetivo de transfectar os plasmídeos utilizados na construção dos vírus recombinantes é avaliar se os promotores de $M d \mathrm{BV}$ são ativados pelo complexo RNA pol II do hospedeiro sem o auxílio de proteínas virais que poderiam auxiliar a transcrição transativando a expressão gênica. A hipótese inicial era de que alguns dos mecanismos de transcrição de mRNA dos genes não-encapsidados do $M d \mathrm{BV}$ são similares aos mecanismos de transcrição das células de Lepidoptera, desta forma os promotores de $M d \mathrm{BV}$ com motivos similares aos da transcrição da fase precoce (prIE1 e prGP64) nos baculovírus devem ser ativados e os promotores com motivos tardios não devem ser transcritos neste experimento. 
Como apresentado na figura 33, os promotores $A c$ IE1 e $A c$ GP64 apresentaram sinais substanciais de luminescência (Teste t, p < 0.0001) em comparação ao controle negativo, reiterando a condição de promotor de fase precoce baculoviral, enquanto os promotores tardios $A c \mathrm{P} 6.9$ e $A c \mathrm{POLH}$ não foram ativados.

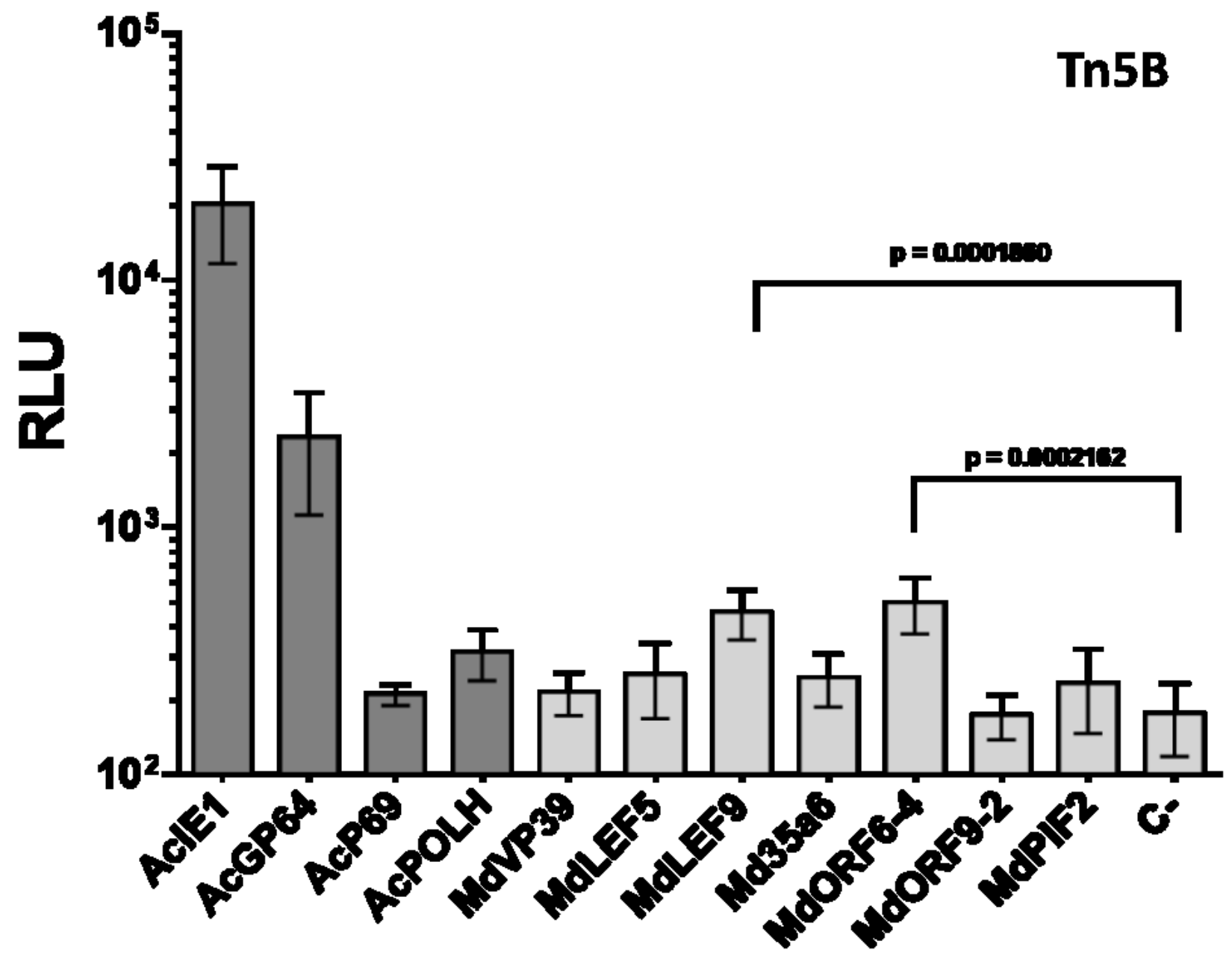

Figura 33: Medição de luminescência a partir da transfecção dos plasmídeos contendo os promotores isolados regulando a luciferase de vaga-lume na linhagem Tn5B. Os pontos de medição representam a média do valor de luminescência e barras o desvio padrão em relação à média. $O$ resultado dos testes $t$ significantes entre promotores MdBV e o controle foram apresentados na imagem.

Os únicos promotores de $M d \mathrm{BV}$ que apresentaram expressão detectável foram MdLEF9 e MdORF6-4, que possuem motivos de transcrição precoce baculoviral e apresentaram fracos sinais mas superiores ao controle negativo (Teste $t, p=000186$ e $p$ $=0.0002162$, apresentados na figura 33). Os promotores $M d V P 39$ e $M d$ LEF5 também possuem elementos precoces de transcrição, no entanto, não expressaram FLUC o 
suficiente para serem estatisticamente significativos ou não foram reconhecidos pela maquinaria celular. Os demais promotores não apresentaram luminescência significativamente distinta do controle negativo o que está de acordo com a hipótese inicial, pois possuem apenas os elementos de transcrição tardia.

O desenho experimental deste ensaio tentou maximizar o sinal de luminescência potencial usando um número 10 vezes maior de células do que o realizado em ensaios de infecção celular. Além disto, foi utilizado o dobro de concentração de DNA (2 $\mu \mathrm{g})$ plasmidial comumente usado por transfecção mas ainda seguindo o procedimento de formação dos complexos lipossomo e DNA, para maximizar a eficiência de transfecçâo, e ainda utilizando $20 \mu \mathrm{l}$ do reagente Luciferina para garantir intenso sinal de luminescência.

O caso dos promotores com elementos tardios pareceu fazer mais sentido do que os precoces. Os promotores de maior pico de expressão neste ensaio, $M d$ LEF9, $M d$ O6-4 e $M d \mathrm{O} 92$, possuem promotores tardios canônicos (INR TAAG em região rica em A e T), enquanto os promotores $M d 35 \mathrm{a} 6$ e $M d \mathrm{PIF} 2$, que possuem apenas o elemento INR TAAG, apresentaram sinais inferiores. Isto faz sentido, pois já foi demonstrado que a alta eficiência da transcrição tardia é garantida pela presença do elemento tardio completo (Chen et al., 2013; Garrity et al., 1997). A descrição dos motivos presentes em cada promotor de $M d \mathrm{BV}$ está apresentada na tabela 7. Como referência também foram apresentados os promotores de $A c \mathrm{MNPV}$ e $A g \mathrm{MNPV}$ de fases precoce e tardia, além de um promotor bimodal. É curioso notar que o gene $M d v p 39$ responsável pela formação do capsídeo viral e abundantemente expresso na vespa adulta possui um promotor totalmente distinto do gene homólogo vp39 em baculovírus. 
Tabela 7: Descrição dos elementos transcricionais presentes nos promotores derivados de MdBV. Os valores de RPKM são derivados do transcriptoma da vespa $M$. demolitor em diferentes estágios de desenvolvimento, durante a fase pupa (em que inicia a expressão precoce dos genes não encapsidados do $M d B V$ ) e durante a fase adulta (expressão tardia) e indicam o número de transcritos mapeados a cada gene (Burke \& Strand, 2012). A função gênica de cada gene é indicada quando conhecida. Também foram apresentados a presença ou ausência dos motivos baculovirais da fase precoce e tardia (indicados por + ou -) e a sequência parcial do sítio de início da transcrição contendo os elementos. A detecção experimental realizada neste trabalho também é indicada.

\begin{tabular}{|c|c|c|c|c|c|c|c|c|}
\hline \multirow[b]{2}{*}{ Nome do gene } & \multicolumn{2}{|c|}{ Vespa } & \multirow[b]{2}{*}{$\begin{array}{l}\text { Função } \\
\text { (pb) }\end{array}$} & \multicolumn{3}{|r|}{ Baculovírus } & \multicolumn{2}{|c|}{ Experimental } \\
\hline & $\begin{array}{l}\text { RPKM } \\
\text { Pupa }\end{array}$ & $\begin{array}{l}\text { RPKM } \\
\text { Adulto }\end{array}$ & & $\begin{array}{l}\text { Motivo } \\
\text { Precoce }\end{array}$ & $\begin{array}{l}\text { Motivo } \\
\text { Tardio }\end{array}$ & Motivos & $\begin{array}{l}\text { Detecção } \\
\text { Precoce }\end{array}$ & $\begin{array}{c}\text { Detecção } \\
\text { Tardio }\end{array}$ \\
\hline AcIE1 & & & Transativador & + & - & $\begin{array}{c}\text { TAATAAAAGAAATATTGTTATCGTGTTCGCCATTAGGGCAGT } \\
\text { TATAAATTGACGTTCATGTTGGATATTGTTTCAGT }\end{array}$ & + & - \\
\hline AgGP64 & & & Envelope & + & + & $\begin{array}{l}\text { TATAAAGGCCTGAGCCGTGCTGGTAAATCAGT } \\
\text { TATTGCAAGATAAG } \\
\text { AGATAAGATATAAG }\end{array}$ & + & + \\
\hline AcP69 & & & Capsídeo & - & + & $\begin{array}{l}\text { ATAACATATITAAG } \\
\text { AAAATATTAATAAG } \\
\end{array}$ & - & + \\
\hline MdVP39 & 3 & 4109 & Capsídeo & + & - & $\begin{array}{l}\text { TCAGTATATGAATAATITAATCGTCGTGCCCAGT } \\
\text { ATCTCGATTCGCACCTAGAACCTTCTTATTCAGT }\end{array}$ & - & + \\
\hline MdLEF5 & 231 & 159 & RNA pol & + & - & TATAAATATTACTGATAAATTTGTAACAGT & - & + \\
\hline MdLEF9 & 54 & 72 & RNA pol & + & + & $\begin{array}{l}\text { TAATATCGTAAAATTTATTTGAATACTCGAAAGAACAGT } \\
\text { ATATTGATATTAAG }\end{array}$ & - & + \\
\hline Md35a6 & $?$ & 260 & ? & - & + & CGCGGTACCGTAAG & - & + \\
\hline MdORF64 & 12 & 1043 & ? & + & + & $\begin{array}{l}\text { AACTGCTITTCGAATCCTTATGACATTCCACAGT } \\
\text { ATGTGITATATAAG }\end{array}$ & - & + \\
\hline MdORF9-2 & 0 & 761 & $?$ & - & + & TATAATTGTIGAGTATITAAG & - & + \\
\hline MdPIF2 & 0 & 448 & Envelope & - & + & TIIITCAGTAAG & - & + \\
\hline
\end{tabular}

A comparação entre baculovírus e PDVs pode não ser tão simples quanto parece.

Os mecanismos de transcrição dos Nudivirus ancestrais podem ter sido anulados e sobrepostos pelos mecanismos de transcrição da vespa M. demolitor (Burke et al., 2014; Dupuy et al., 2006), de forma que os motivos de transcrição precoces e tardios ainda presentes são apenas "fósseis" nos fragmentos isolados e perderam o contexto original necessário para servirem como promotores precoces de uma infecção lítica em Lepidoptera.

Uma hipótese potencial sobre a causa da sua inativação durante a evolução dos PDVs é que estes promotores da fase precoce dos baculovírus são otimizados para reconhecimento direto do complexo RNA pol II ativo em artrópodes. Portanto não são "controláveis" pela célula. Se a funcionalidade destes fossem mantidas, ocorreria a produção de partículas virais de PDVs ao longo de todo corpo da vespa. Ao anular a característica "vazante" ou housekeeping (sempre ativas) destes promotores precoces, 
conforme observado nos baculovírus, foi possível domesticar e controlar o Nudivírus ancestral e torná-lo o PDV, com indução altamente específica dentro de apenas um tecido de fêmeas de um organismo complexo e multifásico como são as vespas parasitas.

Desta forma, não há uma equivalência direta entre as classes precoce e tardia dos PDVs e baculovírus. Colocado de outra forma, estes dados não permitem modelar a regulação dos PDVs em células de vespas, argumentando contra a visão comum e utilizada nos demais trabalhos com os PDVs, de que os baculovírus são uma boa referência para compreender a biologia destes vírus endógenos. Esta correlação é muito útil para entender a imunossupressão que os PDVs causam nas lagartas hospedeiras. Este seria o lado baculovírus que existe e é preservado nos PDVs (os genes encapsidados). No entanto, a formação das partículas virais e os mecanismos de regulação ainda nas vespas (genes não-encapsidados) é o lado simbiótico de um vírus endógeno a uma vespa que não possui modelo comparável.

\subsection{O perfil dos promotores de genes não encapsidados de $M d B V$ durante transduções de células de inseto não-Lepidoptera}

Apesar deste trabalho focar em linhagens celulares derivadas de Lepidoptera, é importante saber qual é a atividade dos promotores de $M d \mathrm{BV}$ em linhagens derivadas de outros insetos pois existem boas referências dos mecanismos de transcrição gênica em algumas espécies modelo, como exemplo, a mosca D. melanogaster (Amin et al., 1985; McIntosh et al.; Morris \& Miller, 1992). Dentro dos insetos, encontramos o grupo denominado Endopterigota, que são insetos que passam por metamorfose radical do corpo. Dentro deste grupo encontramos o grupo Mecopterida, que inclui o grupo Diptera (com subgrupos Drosofilidae - moscas e Culicidae - mosquitos) e Lepidoptera (borboletas e mariposas), e o grupo Himenoptera (vespas, abelhas e formigas). As linhagens testadas 
são derivadas de cada subgrupo, S2 como representante de Diptera - Drosofilidae, Aaeg2 como Diptera - Culicidae e MdE como representante do grupo Himenoptera.

A atividade dos promotores "promíscuos" de D. melanogaster, assim denominados por serem funcionais em múltiplas linhagens celulares com origens filogeneticamente distantes, por exemplo o promotor de housekeeping amplamente utilizado hsp70 e seu enhancer (Amin et al., 1987), indicam que alguns destes promotores promíscuos sejam beneficiados por possuírem uma propriedade arquetipal reconhecida amplamente, com diferenças em eficiência, pelos elementos conservados das RNA polimerases do amplo grupo Metazoa. Sem um estudo que utilize um grande número de linhagens de inseto comparando um mesmo promotor é muito difícil concluir o espectro total destes promotores e o quão conservado é o mecanismo de transcrição em insetos. No caso dos baculovírus, o promotor IE1 é considerado um promotor promíscuo, com atividade em diversas linhagens de inseto (Jarvis et al., 1996) e até mesmo em mamíferos (Kenoutis et al., 2006; Liu et al., 2007). Como já foi explorado anteriormente, este promotor tem que ser reconhecido pela RNA pol II do hospedeiro Lepidoptera e assim expressar a proteína IE1 que irá realocar o maquinário de transcrição da célula hospedeira para os demais promotores virais, um evento crucial na infecção celular pelos baculovírus.

Utilizando os baculovírus $A c \mathrm{MNPV}$ contendo os promotores $M d \mathrm{BV}$ e os bacmídeos contendo os promotores prAcIE1, prAcGP64 e prAcP6.9 em transduções de células não permissivas foi possível complementar os experimentos de transfecção realizados. A MOI 10 garante estatisticamente que todas as células devem receber pelo menos uma partícula viral no momento inicial de transdução e 48 h de transdução (h p.t.) foi considerado como tempo suficiente para acúmulo de proteína expressa para ser detectada. Neste experimento, as linhagens utilizadas foram Tn5B como referência 
positiva de expressão gênica auxiliada pelos fatores virais e as linhagens Aaeg2, S2 e MdE como testes para avaliar atividade dos promotores em células não-permissivas (Figura 34). Neste experimento, a hipótese básica inicial é que os promotores com elementos baculovirais precoces devem ser ativados em linhagens celulares derivadas de insetos pois o mecanismo de transcrição de RNA mensageiro pela RNA pol II é muito similar dentro do grupo Insecta. Esta hipótese vem com reservas pois apesar do mecanismo de transcrição dos baculovírus em células de Lepidoptera ser bem conhecido durante a infecção, a transdução de células de inseto não-permissivas nunca foi bem explorada e não temos informação suficiente para saber quais genes do próprio baculovírus são expressos e podem contribuir com a expressão gênica.

Os resultados obtidos das transduções das linhagens MdE e Aaeg (Figura 34) indicam uma inabilidade dos baculovírus transduzidos em expressar o gene repórter em todos os casos (diferença não significativa do controle, Teste $t, p>0.01$ ). Isto é indicativo direto que nenhum dos promotores isolados são ativados nestas duas linhagens.

A linhagem S2 (Figura 34) ativou o promotor AcIE1 de forma similar ao ensaio de transfecção. Por outro lado, o sinal de luminescência do prAcGP64 foi fraco e não foi significativamente distinto do controle negativo. Surpreendentemente, o promotor tardio prAcP6.9 apresentou atividade nesta linhagem celular, lembrando que este elemento não possui motivos de transcrição precoces e sua atividade depende da replicação do DNA viral do baculovírus. A quantificação do DNA viral nesta linhagem ao longo da transdução prova que não ocorre replicação do baculovírus em S2, mas o DNA viral também não degrada ao longo do tempo, permanecendo estável (Figura 36). Portanto, a detecção deste sinal na transdução e não na transfecção sugere que proteínas do próprio baculovírus podem estar auxiliando a ativação deste promotor nesta linhagem ou que esta célula reconhece algum elemento de ativação da transcrição em Drosophila ainda 
desconhecido, que está contido neste promotor. Os promotores derivados de $M d \mathrm{BV}$ por sua vez não apresentaram qualquer atividade significativa nesta linhagem.

A infecção da linhagem permissiva à infecção Tn5B foi apresentada na figura 34 . As 48 h p.i., os sinais de luminescência dos promotores baculovirais são pelo menos 10 vezes maiores que os valores mais altos obtidos na linhagem S2 que obteve alguma luminescência da transdução. O promotor prAcP6.9 apresentou um sinal de $5.4 \times 10^{4}$ RLU. Os promotores derivados de $M d \mathrm{BV}$ que apresentaram sinais significativamente distintos do controle na ordem de menor a maior intensidade foram $M d$ LEF5, $M d$ LEF9, MdVP39, MdO64 e MdO92 ( $<$ 0.0001). Os promotores Md35a6 e MdPIF2 não apresentaram luminescência significativamente distinta do controle negativo. Surpreendentemente, o sinal de luminescência do promotor $M d \mathrm{O} 92\left(2.8 \times 10^{4} \mathrm{RLU}\right)$ foi comparável ao do promotor tardio pr $A c \mathrm{P} 6.9$, indicando que este promotor de $M d \mathrm{BV}$ é reconhecido e transativado pelas proteínas associadas à hiperexpressão gênica em momentos tardios. Os promotores $M d \mathrm{VP} 39, M d$ LEF9 e $M d \mathrm{O} 64$ apresentaram sinais de luminescência equivalentes ao do promotor precoce baculoviral $A c$ IE1. A infecção dos baculovírus $A c \mathrm{MNPV}$ recombinantes na linhagem Tn5B também foi avaliada pelo método de detecção de luminescência em tempo real que está apresentado na seção 
seguinte e permite uma discussão melhor da atividade dos promotores de $M d \mathrm{BV}$ em uma linhagem permissiva.
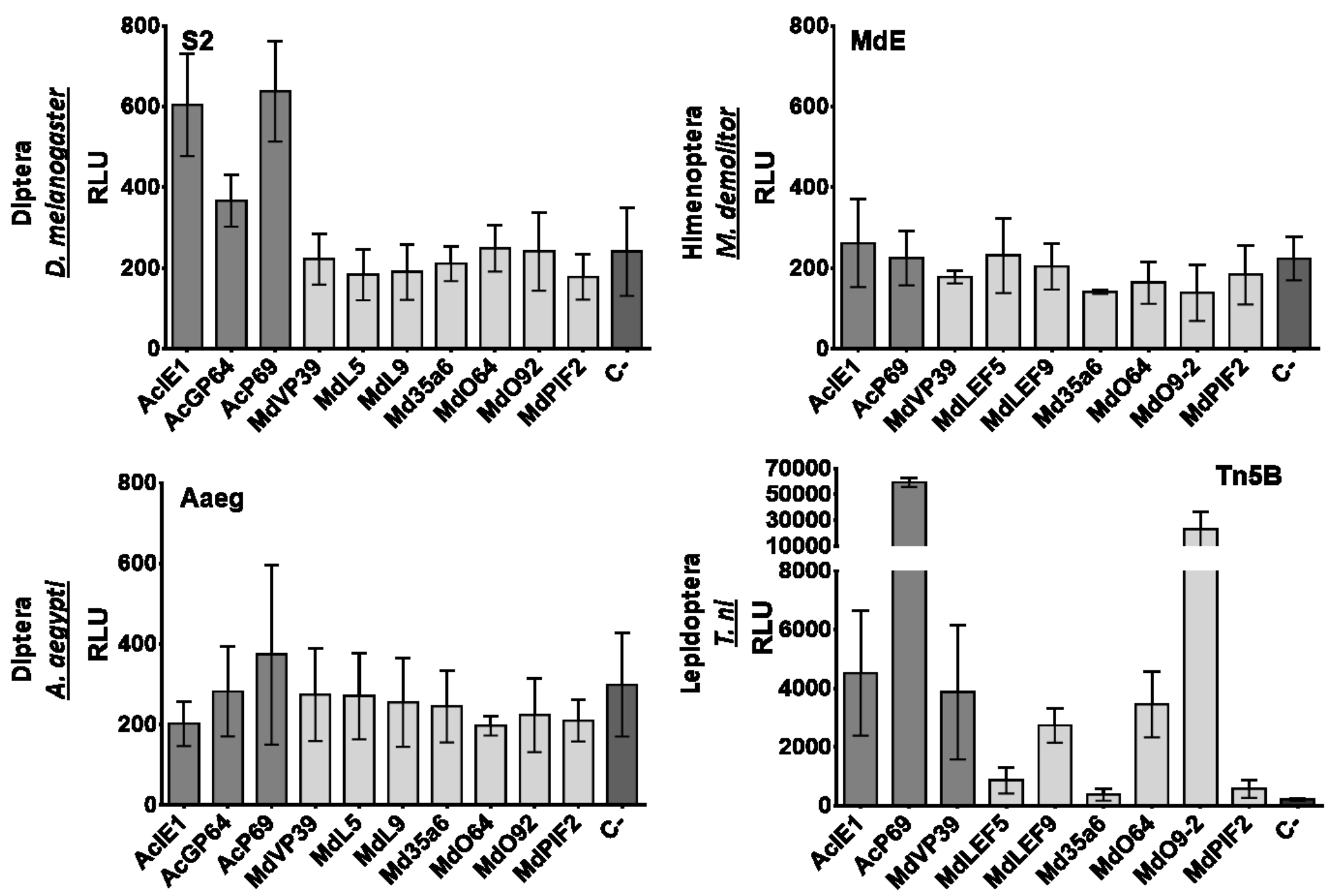

Figura 34: Medição de luminescência de células transduzidas (S2, MdE e Aaeg) e infectadas (Tn5B) com os baculovírus recombinantes contendo promotores virais regulando o gene fluc. Cada ponto de medição representa a média e as barras o desvio em relação à média de triplicatas de medição $48 \mathrm{~h}$ p.i..

Mas o que pensar dos promotores de genes precoces não-encapsidados do $M d \mathrm{BV}$ ?

Diferente tanto do $h s p 70$ de D. melanogaster, que controla um gene ativo e expresso continuamente pela célula e diferente do IE1 dos baculovírus que é um oportunista dentro dos primeiros momentos da infecção, os genes precoces não-encapsidados (MdLEF5 e MdLEF9) são controlados por sinais do desenvolvimento da vespa fêmea em um estágio específico (Strand \& Burke, 2012; Wyler \& Lanzrein, 2003). Esta condição implica em um promotor induzível e temporalmente controlado em um contexto maior do organismo 
como um todo, possivelmente envolvendo hormônios de crescimento. Se estes promotores não fossem controlados de forma bem restritiva, ocorreria expressão gênica a partir dos segmentos virais em todo o corpo da vespa, o que nunca foi observado (Wyler \& Lanzrein, 2003). Os resultados negativos obtidos na expressão dos promotores de $M d \mathrm{BV}$ nas células não-permissivas parece apontar exatamente nesta direção, que a ativação destes elementos endógenos da vespa requer sinais e elementos bastante específicos ao tecido responsável pela produção do vírus no ovário, não existindo equivalente conhecido em cultura celular até o momento.

Apenas a linhagem S2 foi capaz de expressar promotores virais e apenas os promotores derivados de baculovírus pr $A c \mathrm{IE} 1$, pr $A c \mathrm{GP} 64$ e pr $A c \mathrm{P} 69$ foram reconhecidos e transcritos. O promotor tardio pr $A c \mathrm{P} 69$ ser funcional nesta linhagem é curioso pois não existem motivos TATA box ou outros motivos conhecidos de transcrição em Drosophila neste promotor e os ensaios de quantificação da replicação do vírus indicam que o DNA viral não replica nesta linhagem. Observação similar foi realizada quando foi utilizado um $A c \mathrm{MNPV}$ com o promotor prAcVP39 em transduções da linhagem Dm, também derivada de D. melanogaster (Morris \& Miller, 1992). Este fenômeno nunca foi investigado novamente e permanece como um ponto interessante a ser explorado.

\subsection{O curioso caso da linhagem celular derivada da vespa Microplitis demolitor}

O estabelecimento de um sistema in vitro para manipulação e estudo dos PDVs é uma meta muito importante. Até o momento, os estudos realizados com o $M d \mathrm{BV}$ utilizaram apenas culturas in vivo de larvas de C. includens e a vespa M. demolitor (Strand \& Burke, 2012). Portanto, é muito difícil realizar experimentos de manipulação genética com alta precisão. O knockout gênico utilizando a transfecção de plasmídeos que expressam RNA interferente para genes selecionados é conduzido em larvas que 
acabaram de sair de dentro do hospedeiro e apresenta baixa eficiência (comunicação pessoal com o dr. Michael Strand, técnica utilizada em Burke et al., 2013). Primeiro pela letalidade da injeção, segundo pela imprecisão do procedimento (a larva de M. demolitor é muito pequena para injeção) e terceiro pela baixa eficiência da transfecção em si, que é um processo de baixa penetração em tecidos densos. Portanto não há garantia que os tecidos de interesse sejam efetivamente transfectados e diferentes indivíduos.

A linhagem MdE foi derivada de ovos retirados diretamente do ovário de $M$. demolitor, estes foram macerados de forma estéril, tripsinizados e as células foram semeadas em placas de cultivo com meio de cultura (Sf900-II contendo $10 \%$ de soro fetal bovino). Após sucessivas passagens, um tipo celular predominante foi nomeado como MdE1. Estas células possuem pequeno tamanho celular comparado com a linhagem Tn5B (metade do diâmetro). Em seu interior não foram encontradas partículas virais do bracovírus por observações de microscopia de transmissão, nem ocorreu amplificação dos segmentos genômicos virais. Diversas tentativas de transfecção com reagentes variados e plasmídeos contendo o gene repórter GFP regulado pelo promotor promíscuo de Drosophila HSP70 não resultou em células com fluorescência (Jena Johnson e Michael Strand, comunicação pessoal). Como os baculovírus são agentes eficientes de entrega gênica em diferentes linhagens celulares (Liu et al., 2007; McIntosh et al.; Morris \& Miller, 1992) cogitou-se a utilização destes recombinantes contendo diferentes promotores para testar a habilidade dos baculovírus em transduzir esta linhagem.

Como observado nos ensaios de transdução, nenhum promotor testado foi funcional nesta linhagem. Promotores "nativos", derivados de segmentos do vírus $M d \mathrm{BV}$, em especial os derivados de genes da fase precoce no ciclo de vida do $M d \mathrm{BV}$ como os promotores $M d$ VP39, $M d$ LEF5 e $M d$ LEF9 não apresentaram nenhuma atividade. Os promotores imediatamente precoces derivados de $A c \mathrm{MNPV}$, prAcIE1 e prAcGP64, 
também foram inativos em MdE. A inatividade, tanto dos promotores precoces baculovirais quanto dos promotores $M d \mathrm{BV}$ durante a transdução da linhagem MdE, levantou a questão sobre a habilidade do baculovírus de efetivamente entrar nesta linhagem celular. A inatividade pode ocorrer devido a diversos bloqueios: as partículas podem ser incapazes de aderir à membrana celular devido a falta de receptores específicos; As partículas podem aderir à membrana celular mas a proteina GP64 não é capaz de fundir a membrana do envelope viral com a membrana celular; As partículas podem entrar na célula mas não trafegar até o núcleo; Caso as partículas entrem no núcleo ainda é possível que não ocorra o desnudamento da partícula viral e se ocorre ainda é possível que os fatores de transcrição nesta célula não reconheçam nenhum dos promotores testados.

A figura 35 A demonstra que o baculovírus $A c$ MNPV foi capaz de induzir fusão de membranas entre as células $\mathrm{MdE}$ em baixo $\mathrm{pH}$, o que ocorre apenas quando as partículas virais estão em contato direto com as membranas plasmáticas. A figura $35 \mathrm{~B}$ prova que a fusão de membranas apenas ocorreu em baixo $\mathrm{pH}$, pois na ausência do choque de pH pela troca de meio, não ocorreu a fusão celular. De forma similar, a figura $35 \mathrm{C}$ demonstra que o vírus também é essencial pois apenas o choque de baixo $\mathrm{pH}$ em células sem partículas virais, não resultou em fusão celular.

Este experimento foi importante por demonstrar que os BVs são capazes de aderir à membrana celular da linhagem MdE e a reação de fusão de membranas induzidas pela proteína GP64 é funcional sobre esta linhagem celular. 


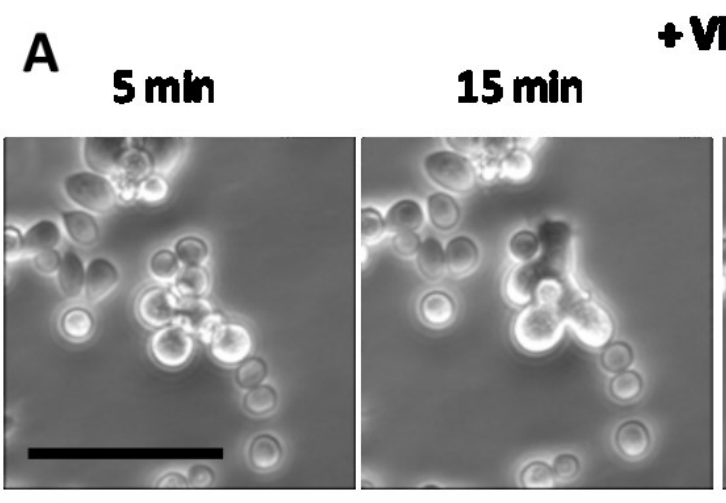

+ Vrus + Choque de pH $30 \mathrm{~min}$

$45 \mathrm{~min}$

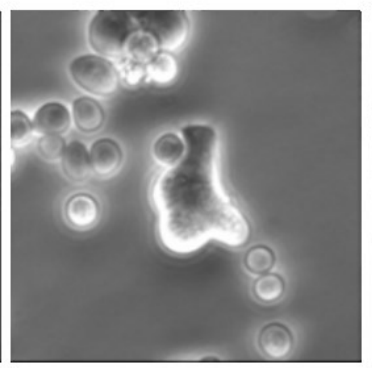

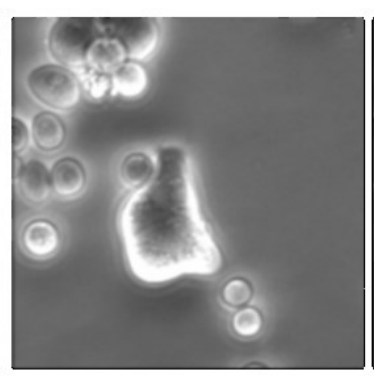

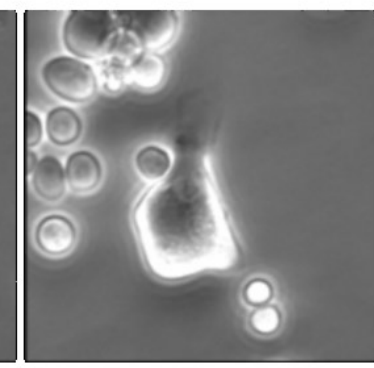

- Choque de $\mathrm{pH}:+$ virus $60 \mathrm{~min}$

B

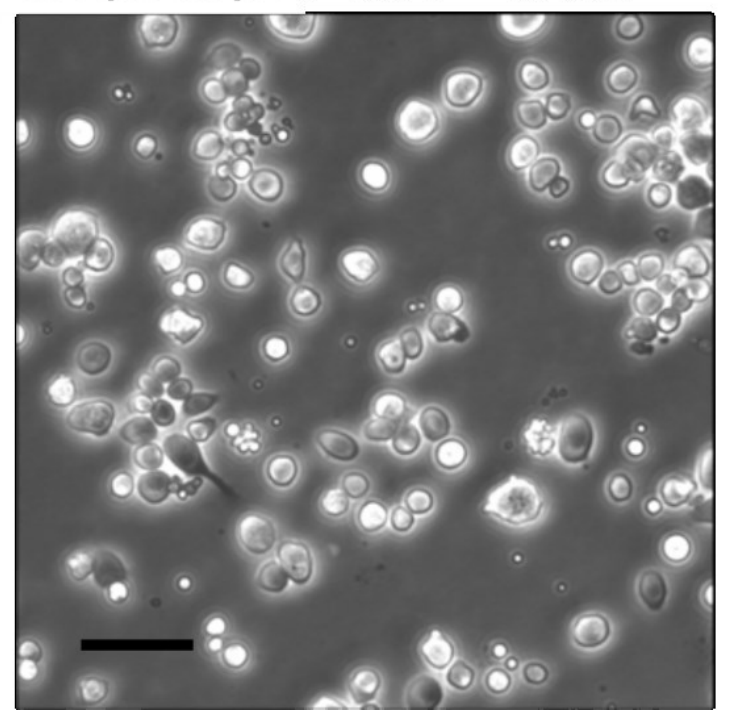

+ Choque de $\mathrm{pH}-$ virus $60 \mathrm{~min}$

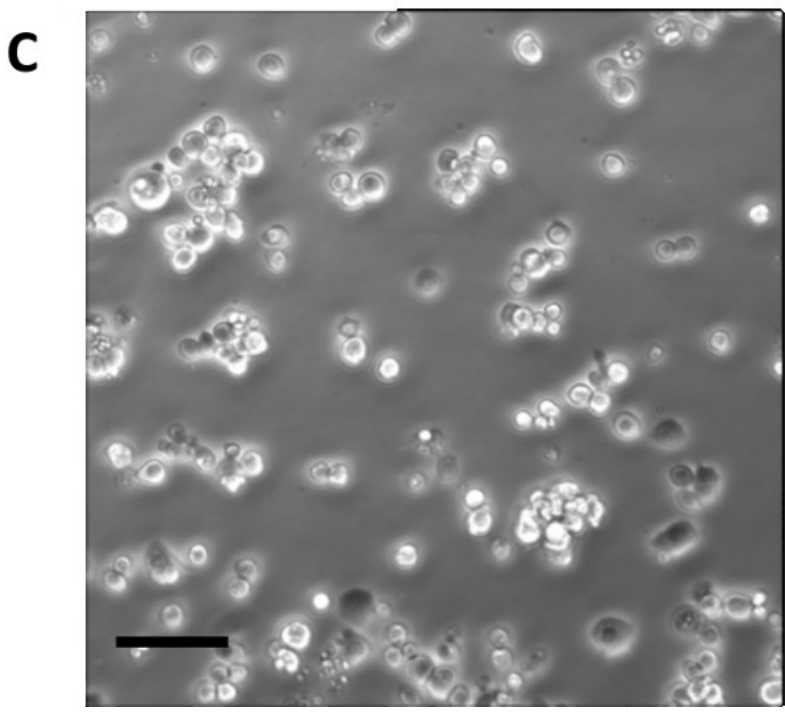

Figura 35: Ensaios de fusão celular da linhagem MdE mediada pela proteína de envelope viral GP64. A - Série de micrografias de um mesmo grupo de células que sofrem fusão celular mediada pela proteína viral após a adição das partículas virais e incubação com meio de cultura com pH 5 ao longo de $60 \mathrm{~min}$. B - Imagem demonstrando que a presença do vírus não é suficiente para induzir fusão celular sem que o meio de cultura esteja em baixo pH. C - Imagem demonstrando que sem a adição do vírus não ocorre fusão celular em pH 5 sem que existam as partículas virais adsorvidas na membrana celular. Dimensão das barras: $50 \mu \mathrm{m}$.

Os ensaios de fusão celular em baixo $\mathrm{pH}$ indicam que o vírus adsorve na membrana e a proteína GP64 é funcional. Este resultado indica que o vírus talvez seja capaz de entrar na célula, apesar de não ser conclusivo, pois ainda é possível que o vírus permaneça adsorvido na membrana sem nunca entrar na célula ou entre na célula mas não chega a entrar no núcleo.

Como a linhagem celular MdE não apresentou expressão do gene repórter a partir da transdução utilizando os $A c \mathrm{MNPV}$ recombinantes, tornou-se necessário avaliar se o baculovírus efetivamente entra nesta célula e o ácido nucléico permanece estável dentro 
da célula para ser transcrito. Para tanto, foi mensurada a concentração de DNA viral em MdE e duas linhagens com respostas distintas à infecção-transdução ao longo do tempo para servir de comparação. Como observado anteriormente, a linhagem derivada do Lepidoptera Trichoplusia ni Tn5B é permissiva a infecção de $A c \mathrm{MNPV}$, resultando em alta expressão gênica em conjunto à rápida amplificação do DNA viral. A linhagem S2 foi capaz de expressar o gene repórter a partir dos promotores baculovirais a $48 \mathrm{~h}$ p.i. e portanto, é esperado que o DNA viral permaneça estável no núcleo desta linhagem, no entanto não existem relatos desta célula produzir algum título viral a partir desta transdução pelo baculovírus (Morris \& Miller, 1993).

Como demonstrado na figura 36, a linhagem Tn5B é capaz de amplificar o AcMNPV em 1000 vezes dentro das primeras $24 \mathrm{~h}$ de infecção. Momentos seguintes demonstraram uma taxa de aumento reduzido, possivelmente devido à liberação de BVs entre 24 e 48 h p.i. e a oclusão de partículas virais nos OBs entre 48 e 72 h p.i., o que reduziria o conteúdo viral intracelular detectável.

A linhagem não-permissiva S2 de D. melanogaster não apresentou aumento ou redução na concentração de DNA viral (sem diferença significativa entre os tempos de medida, teste $\mathrm{T}, \mathrm{p}>0.01$ ), e em conjunto ao resultado positivo na expressão de promotores baculovirais, é possível afirmar que o baculovírus efetivamente transduz a célula, chega ao núcleo, é desnudado, transcrito por algum complexo transcricional celular (RNA pol II possivelmente) e ainda permanece estável dentro da célula durante pelo menos $72 \mathrm{~h}$ p.i.. 
Por outro lado, a linhagem derivada de Himenoptera MdE apresentou um decaimento gradual do DNA viral, sugerindo uma instabilidade do ácido nucléico viral dentro da célula. Também levando em consideração a observação de que nenhum promotor é ativo durante a transdução desta célula, incluindo os promotores derivado de $M d \mathrm{BV}$, que são "nativos" à espécie de onde a célula foi derivada. Esta sugestão aparece com reservas, pois ainda existe a possibilidade de que os vírions apenas adsorvem à membrana celular e permanecem aderidos. Ou ainda é possível que o vírus efetivamente entre na célula mas permaneça no endossomo após entrada e seja degradado sem nunca atingir o núcleo celular.

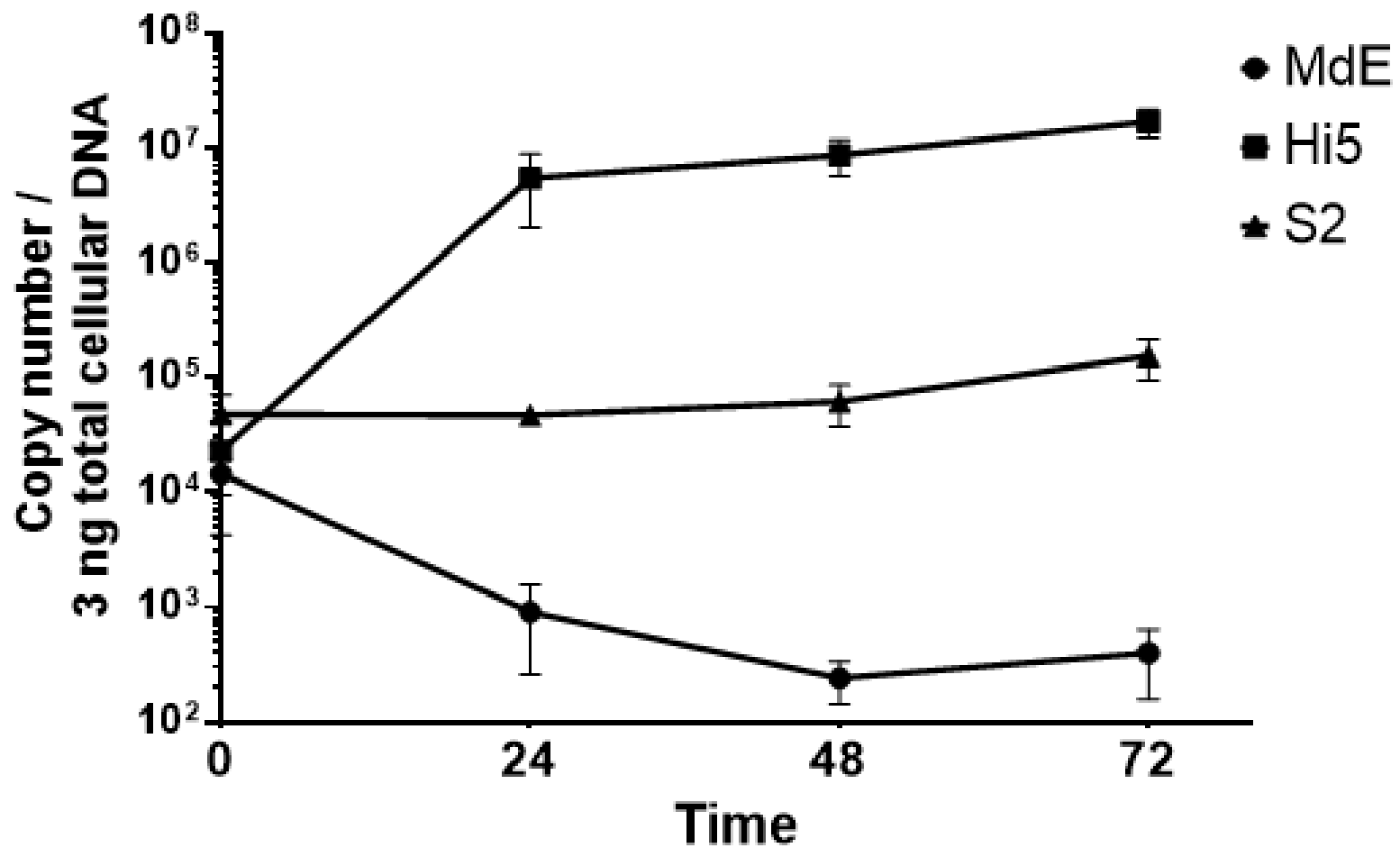

Figura 36: Análise da concentração de DNA do vírus AcMNPV ao longo de 72 h de infecção da linhagem Tn5B (Hi5) e transdução das linhagens S2 e MdE. Os pontos de medição representam a média de triplicatas e as barras representam o desvio padrão em relação à média.

No momento zero (0) de transdução ou infecção, que corresponde à $1 \mathrm{~h}$ após adição do vírus ao sobrenadante, a diferença nos valores de concentração de DNA não são significativas (Teste t, $p>0.1$ ). Após 24 h p.i. as diferenças entre concentrações nas distintas linhagens são significativas (Teste $\mathrm{t}, \mathrm{p}<0.0001)$. 
A quantificação do DNA baculoviral interno à célula indicou que a célula MdE degrada o ácido nucleico viral dentro de 24 h após a transdução. Este resultado também aponta na direção de que o vírus efetivamente entrou na célula. Se as partículas permanecessem aderidas na membrana ainda seria possível detectar níveis similares ao primeiro momento de transdução após 48 h. A quantificação na linhagem de Drosophila S2 demonstrou que uma célula efetivamente transduzida é capaz de manter o DNA viral estável no núcleo ao longo de 72 h. A expressão gênica então é determinada pela eficiência do reconhecimento do promotor que regula o gene repórter. É seguro dizer que os baculovírus não são capazes de transduzir a linhagem S2 devido a instabilidade do DNA viral dentro da célula após a transdução. Isto pode explicar também por que a transfecção de DNA plasmidial não é funcional, pois a célula pode degradar o DNA plasmidial antes de ocorrer expressão suficiente para ser detectada.

Outros experimentos foram conduzidos tentando estimular a transdução pelos bacmídeos. Superinfecções com MOI 100 ou 500 falharam em induzir qualquer expressão. Ensaios de quantificação da luminescência foram conduzidos após adição do vírus e o choque de $\mathrm{pH}$ como realizado no ensaio de fusão celular, sem sucesso. Além disto, foi testada a adição de afidicolina no meio de cultura, igualmente sem sucesso. A expectativa era que a inibição da replicação celular poderia aumentar a estabilidade do DNA viral no núcleo.

O composto sódio butirato também foi testado, também sem sucesso. Este composto promove alterações no padrão de metilação do DNA celular e altera o perfil geral de expressão de células de mamíferos, potencialmente estimulando a transcrição de DNA exógeno inserido nas células (Boffa et al., 1981; Contreras-Leal et al., 2016; Suzuki et al., 2011). A expectativa era que as alterações do perfil transcricional de MdE iriam gerar um ambiente mais propício à transdução pelo baculovírus $A c$ MNPV recombinante. 
A linhagem celular derivada da vespa M. demolitor é completamente “intransduzível” pelo baculovírus $A c \mathrm{MNPV}$ o que reduz consideravelmente a capacidade de manipulação desta célula para estudos da biologia do vírus $M d \mathrm{BV}$. A sua origem de ovos, que possuem tecidos não-diferenciados pode ser um fator importante. Enquanto o ovário é um tecido da fase final do ciclo de vida da vespa. Talvez o uso potencial mais importante desta linhagem será precisamente identificar qual elemento celular efetivamente ativa a transcrição dos genes precoces de $M d \mathrm{BV}$ e assim iniciar a replicação viral e consequente produção dos vírions. Quando este fenômeno for artificialmente induzível, existirão duas condições para estudar profundamente os mecanismos de controle da expressão gênica neste organismo complexo. 


\section{CONCLUSÃO}

O método de detecção contínua do sinal quimioluminescente apresenta a atividade transcricional dos promotores de forma dinâmica, com alta resolução e sensibilidade de forma a revelar uma riqueza de detalhes previamente não observados devido a baixa resolução dos dados obtidos por métodos em que a coleta de dados envolve a lise celular (análise de seção cruzada). A análise em tempo real de uma mesma população de células (análise longitudinal) infectadas de forma síncrona aumenta ainda mais a confiança de que o fenômeno observado correlaciona diretamente com os processos celulares associados à infecção por baculovírus.

Quando a atividade dos diferentes promotores são observadas em conjunto após a infecção independente com os vírus recombinantes é possível identificar e diferenciar claramente as fases de infecção temporalmente distintas e associadas à ativação de cada promotor, classicamente definidos como imediatamente precoces (prIE1, prGP64), precoce atrasados (prLEF1, prVP39), tardios (prVP39, prP6.9) e muito tardio (prPOLH). Isto reforça o conceito que a regulação da expressão temporal dos baculovírus é primariamente determinada por elementos cis definidos como motivos de transcrição. Além disto, o uso de vírus $A g \mathrm{MNPV}$ recombinantes permitiu a caracterização detalhada do perfil de atividade dos promotores deste baculovírus de ampla utilização como bioinseticida, mas com limitado conhecimento de mecanismos moleculares.

Pela infecção de células com diferentes permissividades a infecção por $A g \mathrm{MNPV}$ foi possível observar que as células permissivas (UFLAg, Tn5B) são capazes de expressar todas as classes de promotores e hiperexpressar os promotores tardios, enquanto que as células semipermissivas e não-permissiva (Sf9, Ld652Y e Chch) são incapazes de hiperexpressar os promotores tardios, sendo ainda imprecisa a causa exata que induz esta falha na hiperexpressão, potencialmente devido à reduzida habilidade de replicação viral 
nesta linhagem. A linhagem Bm5 apresentou total incapacidade de expressar promotores tardios certamente devido à morte celular induzida pela expressão de proteínas virais durante a fase precoce da infecção o que interrompe a sequência de transcrição gênica necessária para o sucesso do controle do metabolismo celular e replicação viral. A quantificação da replicação viral e formação do fenótipo BV também sustentam as afirmações anteriores, indicando que em linhagens semipermissivas e não-permissivas a replicação é limitada (atrasada ou até mesmo nula), enquanto que a formação de vírus maduro é reduzida consideravelmente ou obliterada. Ao tratar as linhagens permissivas com o inibidor de replicação de DNA Afidicolina, os promotores apresentam um perfil de expressão similar ao que ocorre na linhagem não-permissiva Bm5. Estes resultados em conjunto apontam para um gradiente de permissividade a não-permissividade de células hospedeiras ao AgMNPV, cujos efeitos podem ser observados pela atividade dos promotores de diversas fases da infecção.

Os ensaios relativos aos parâmetros de MOI permitiram observar o efeito de retardo na expressão em baixas MOIs, relativo à infecção primária de poucas células e a subsequente, mas demorada, proliferação da progênie viral para as demais células. Em altas MOIs observa-se pouca diferença no tempo de ativação dos promotores, representante da saturação das células infectadas com partículas virais logo nas primeiras horas de infecção. O excesso de partículas virais não induz maiores níveis de luminescência nem acelera a ativação dos promotores. O ensaio com variações no número de células revelou que quanto maior o número de células maior o sinal relativo dos promotores, sendo que a condição de confluência total $\left(1 \times 10^{6}\right.$ células / $\left.\mathrm{ml}\right)$ apresentou o maior sinal. Em conclusão, os parâmetros ótimos para a obtenção máxima de expressão com o mínimo de gasto de recursos é a confluência 100\% e a multiplicidade de infecção 10. 
A avaliação da atividade dos promotores de AcMNPV e AgMNPV quando clonados no AcMNPV demonstraram que os elementos controladores de ambos vírus são intercambiáveis, mantendo os perfis de expressão de promotores de AgMNPV (excluindo prAgIE1). O vírus AgMNPV parece ser mais rápido e mais eficiente em termos de expressão de proteínas. As diferenças principais detectadas entre os dois vírus foi que o AcMNPV apresentou uma reduzida expressão gênica durante a fase precoce e uma expressão atrasada de prLEF1. Nas linhagens permissivas os perfis são praticamente idênticos entre os dois vírus, enquanto nas linhagens não-permissivas Chch e Bm5 detectamos maiores diferenças, com uma limitação maior da expressão em Chch e fraca expressão de promotores tardios em Bm5, o que indica que o AcMNPV é capaz de replicar fracamente nesta linhagem.

Outro ponto importante que podemos retirar da caracterização dos promotores é que o promotor $\operatorname{pr} A g \mathrm{POLH}$ ou $\operatorname{pr} A c \mathrm{POLH}$ não foram os mais produtivos considerando os valores de pico de expressão. Os promotores prVP39 e prP6.9 de ambos baculovírus, AcMNPV e AgMNPV, apresentaram uma expressão equivalente, senão maior, do que prAgPOLH em um tempo de infecção mais curto, sendo assim mais eficientes para a produção de proteínas heterólogas.

Os ensaios que avaliaram a atividade dos promotores de genes não-encapsidados de MdBV apresentaram perfis de expressão tardios inesperados, sem detecção durante momentos precoces mesmo para os promotores com motivos de transcrição "adequados" para tal. É interessante observar que o baculovírus AcMNPV aparentemente foi capaz de expressar fortemente os promotores tardios e são reconhecidos pela RNA pol viral. A inatividade dos promotores de MdBV em linhagens que não são derivadas de Lepidoptera também é um resultado elusivo, pois era esperado que os promotores com elementos precoces fossem funcionais, assumindo uma conservação fundamental destes em 
Artrópodes. Esta limitação na expressão precoce aponta para um ponto importante: não existe correlação direta entre a expressão precoce na biologia de polyDNAvírus, como o MdBV, e a expressão precoce na biologia dos baculovírus. É possível que o controle da expressão precoce de MdBV seja extremamente limitada e regulada para ser funcional apenas durante a fase de crescimento apropriada no corpo da vespa, perdendo então os elementos controladores ancestrais do Nudivírus arquetipal que se integrou no genoma.

O baculovírus AcMNPV não foi capaz de transduzir a linhagem celular derivada de vespa MdE, apresentando instabilidade na manutenção do genoma viral dentro da célula portanto não serve como uma boa ferramenta de entrega gênica. Se esta linhagem fosse manipulável ou induzível seria possível elucidar melhor os mecanismos de expressão gênica de MdBV durante a fase precoce e também a produção de vírions na fase tardia.

Futuras explorações utilizando a metodologia de medição de quimiluminescência em tempo real deverão avaliar: Promotores de genes únicos encontrados em diversas espécies de baculovírus; Construir promotores sintéticos com alterações específicas na sequência para testar contextos e distâncias da topologia dos promotores; Construir baculovírus recombinantes com deleções ou adições de genes associados a controle celular; E testar compostos e suplementos ao meio de cultura que poderiam aumentar a eficiência da expressão gênica. 


\section{ANEXOS}
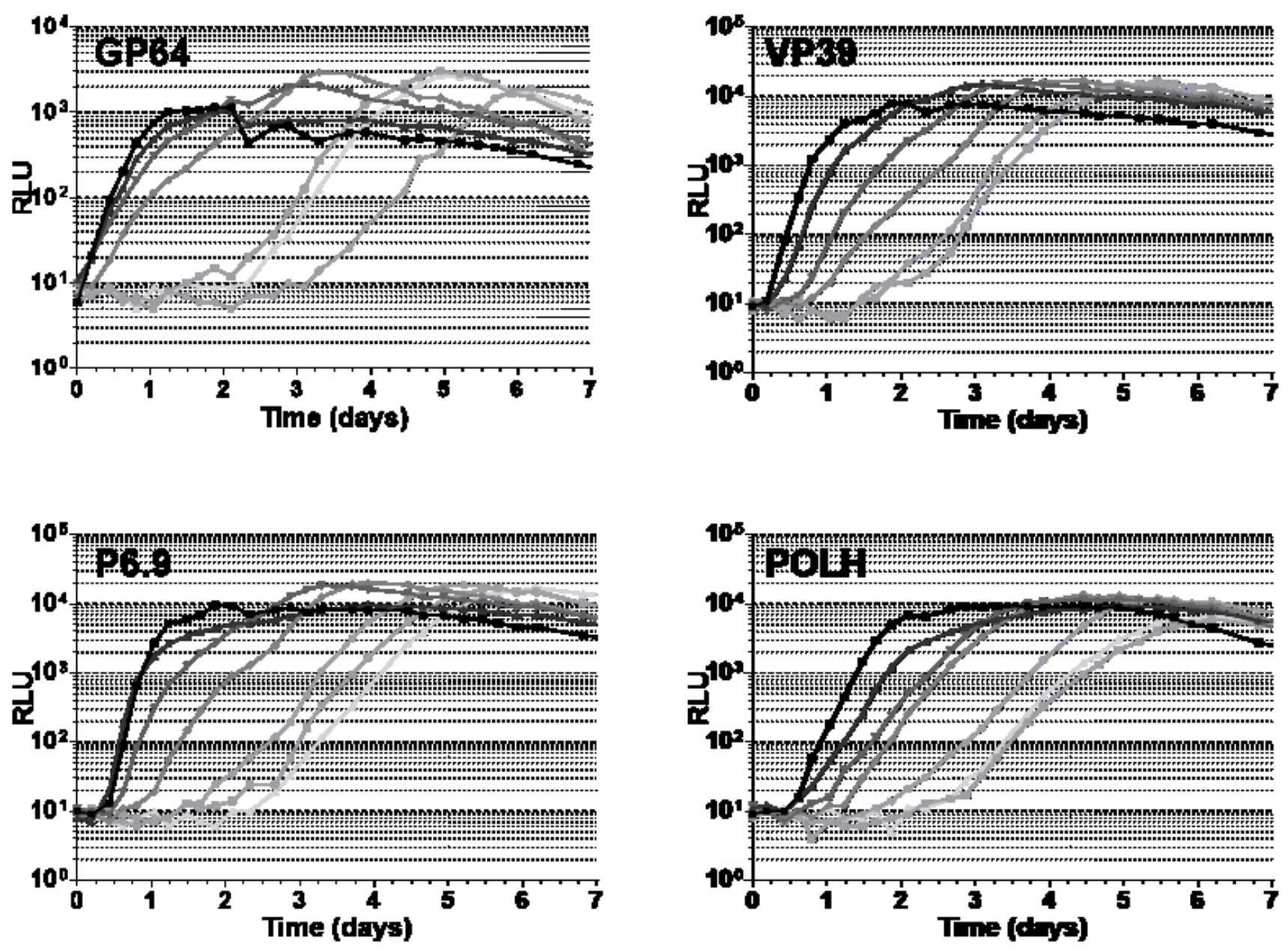

\section{UFLAg $\quad=100 \div 50 \div 10 \approx 1=0,1=0,01=0,001$}

Figura 37: Curvas de expressão do gene repórter fluc durante as infecções da linhagem UFLAg pelos baculovírus AgMNPV recombinantes contendo promotores dos genes gp64, vp39, p6.9 e polh. As MOls utilizadas variaram de 100 a 0.001 em passos de 1 log de magnitude. Pontos representam a média de triplicatas. 

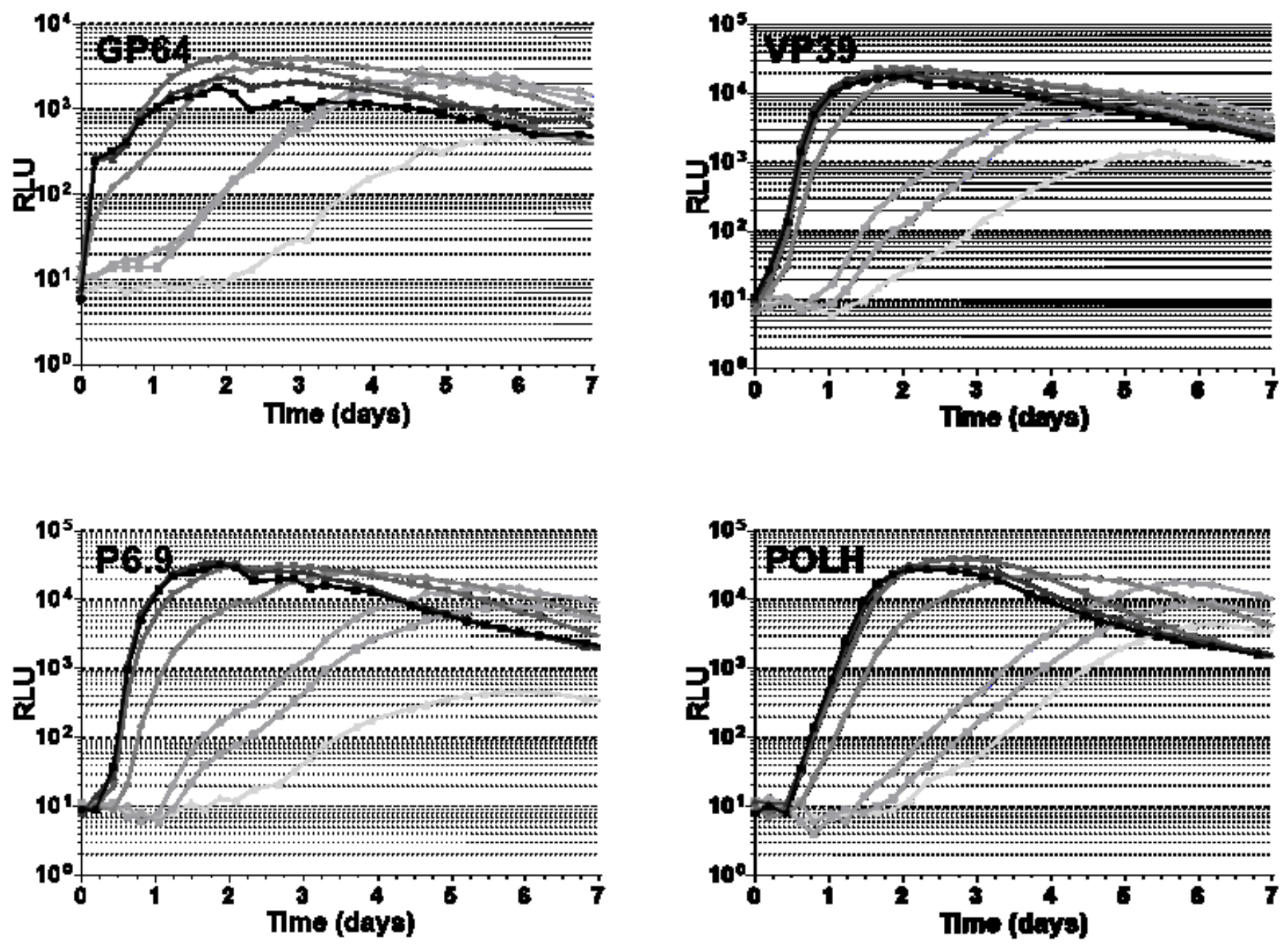

\section{Tn5B $-100-50 \Rightarrow 10 \approx 1 \Rightarrow 0,1=0,01=0,001$}

Figura 38: Curvas de expressão do gene repórter fluc durante as infecções da linhagem Tn5B pelos baculovírus AgMNPV recombinantes contendo promotores dos genes gp64, vp39, p6.9 e polh. As MOls utilizadas variaram de 100 a 0.001 em passos de 1 log de magnitude. Pontos representam a média de triplicatas. 

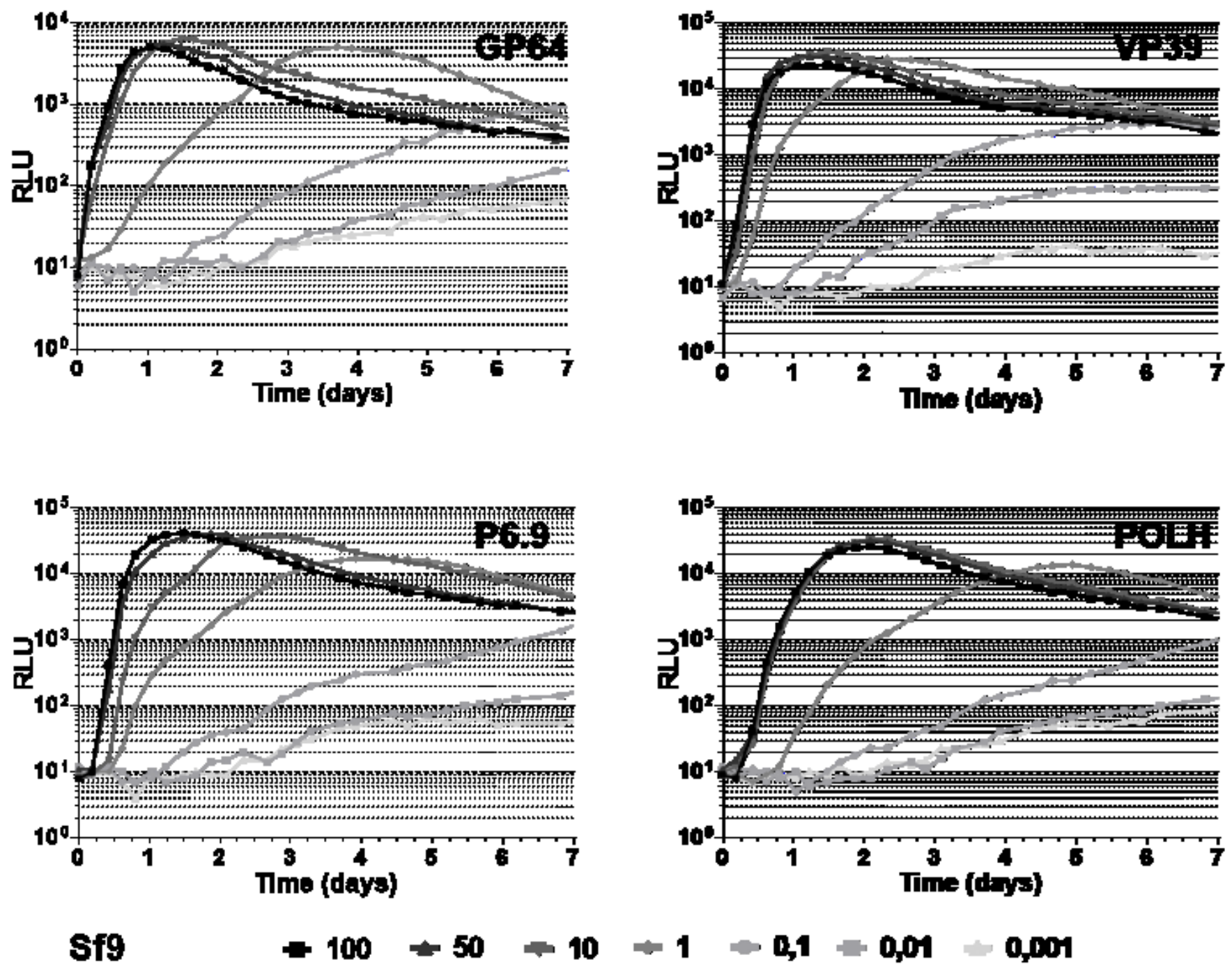

Figura 39: Curvas de expressão do gene repórter fluc durante as infecções da linhagem Sf9 pelos baculovírus AgMNPV recombinantes contendo promotores dos genes gp64, vp39, p6.9 e polh. As MOls utilizadas variaram de 100 a 0.001 em passos de 1 log de magnitude. Pontos representam a média de triplicatas. 


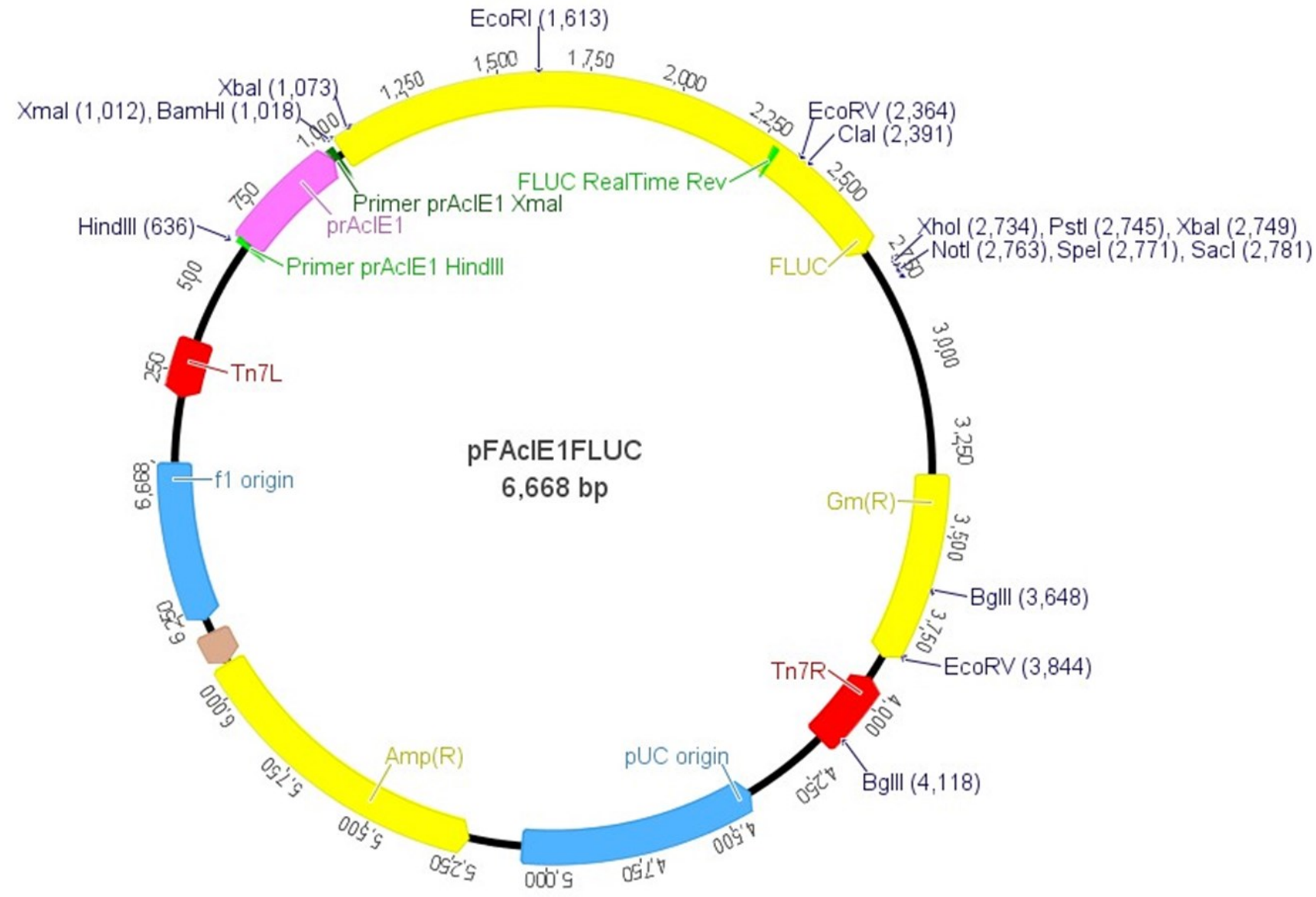

Figura 40: Exemplo de mapa vetor do plasmídeo de transferência por transposição pFASTBAC modificado. Neste caso estão presentes o gene repórter FLUC e o promotor prAcIE1. O mapa vetor é comum a todos os plasmídeos construídos, mudando apenas os promotores que foram isolados e clonados a montante do gene FLUC 
o pFACIE1FLUC
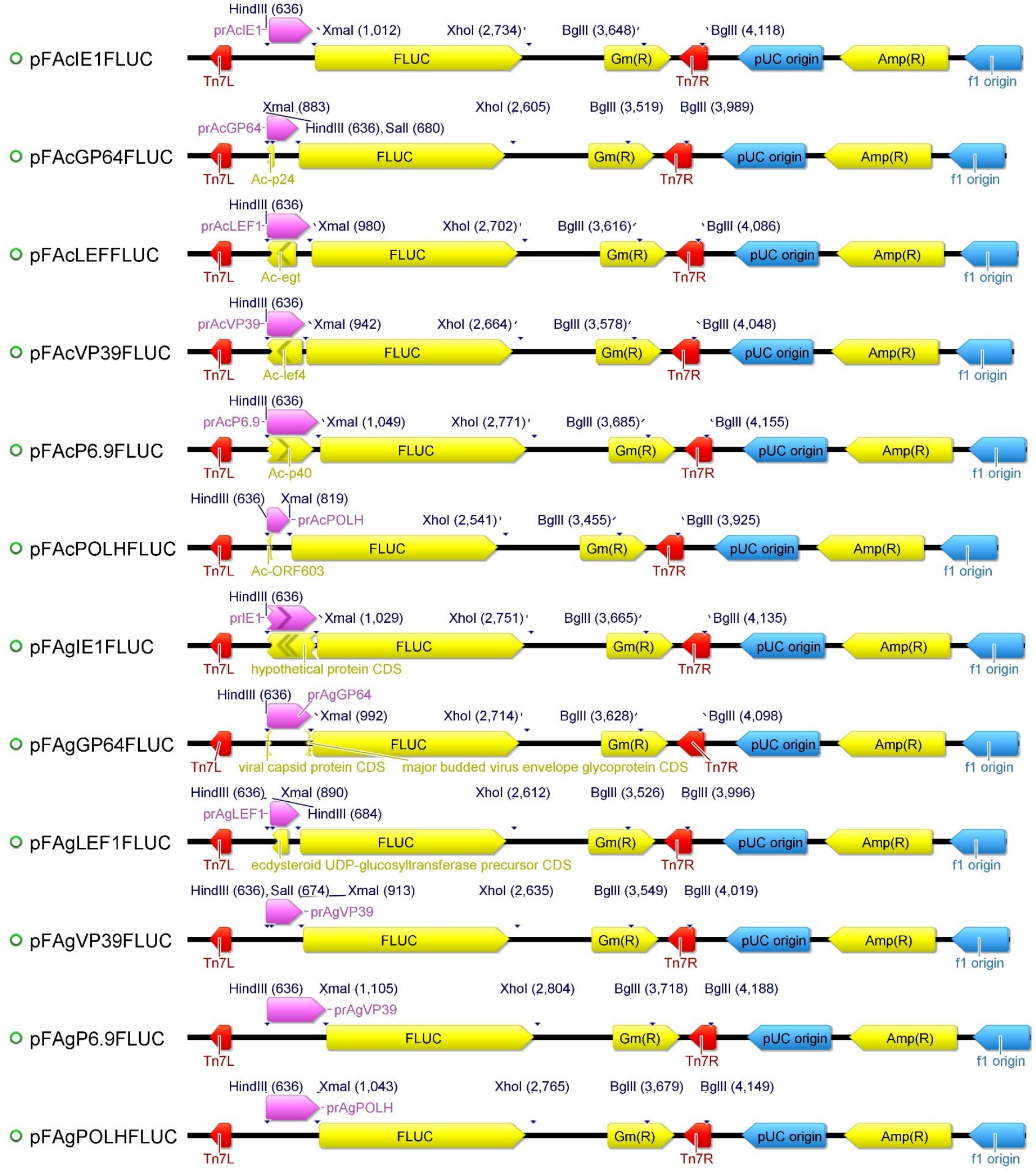

Figura 41: Mapas vetores linearizados dos plasmídeos pFASTBAC modificados contendo os promotores de AcMNPV e AgMNPV isolados e clonados a montante do gene FLUC. 


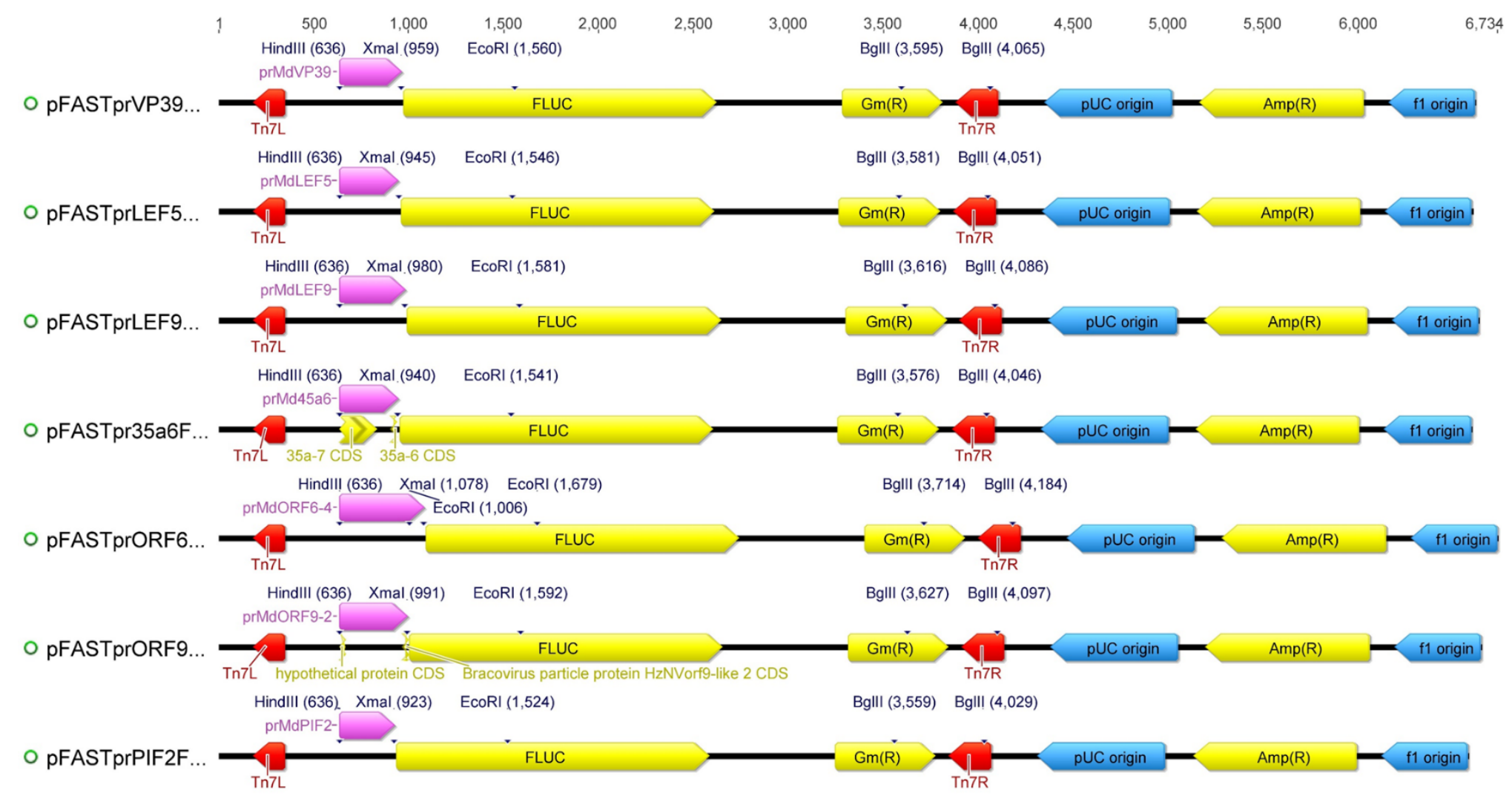

Figura 42: Mapas vetores linearizados dos plasmídeos pFASTBAC modificados contendo os promotores de MdBV isolados e clonados a montante do gene FLUC. 


\section{REFERÊNCIAS BIBLIOGRÁFICAS}

Ardisson-Araújo, D. M. P.; Genômica, evolução e caracterização funcional de genes de baculovírus - Tese (doutorado) - Universidade de Brasília, Instituto de Ciências Biológicas, Brasília. 2015

Cota, V. L.; Aumento populacional da Chrysodeixis includens (Lepidoptera:Noctuidae, Plusiinae) na cultura da soja no Brasil: uma revisão. TCC - Universidade Federal de São João Del Rei, Sete Lagoas, 2015

Morgado, F. da S.; Análise da atividade transcricional dos promotores dos genes $p 6.9$, ie-1, gp64, vp39, p10 e polh do Anticarsia gemmatalis multiple nucleopolyhedrovirus (AgMNPV) e do promotor CMVie1 de um herpesvirus - Tese (Mestrado) - Universidade de Brasília, Instituto de Ciências Biológicas, Brasília. 2012

Pinedo, F. J. R.; Estudo de promotores de genes do baculovírus de Anticarsia gemmatalis durante a infecção de células de inseto e análise do recombinante $\mathrm{v} A g E G T($ delta)-lacZ. Tese (doutorado) Universidade de Brasília, Instituto de Ciências Biológicas, Brasília. 2004.

Abot, A.R., Moscardi, F., Fuxa, J.R., Sosa-Gómez, D.R., Richter, A.R., 1996. Development of Resistance by Anticarsia gemmatalis from Brazil and the United States to a Nuclear Polyhedrosis Virus under Laboratory Selection Pressure. Biological Control 7, 126-130. doi:10.1006/bcon.1996.0075

Amin, J., Mestril, R., Lawson, R., Klapper, H., Voellmy, R., 1985. The heat shock consensus sequence is not sufficient for hsp70 gene expression in Drosophila melanogaster. Molecular and cellular biology 5, 197-203.

Andrade, F.G. de, Negreiro, M.C.C. de, Levy, S.M., Fonseca, I.C. de B., Moscardi, F., Falleiros, Â.M.F., 2010. Hemocyte quantitative changes in Anticarsia gemmatalis (Lepidoptera: Noctuidae) larvae infected by AgMNPV. Brazilian Archives of Biology and Technology 53, 279-284. doi:10.1590/S1516-89132010000200005

Annaheim, M., Lanzrein, B., 2007. Genome organization of the Chelonus inanitus polydnavirus: excision sites, spacers and abundance of proviral and excised segments. The Journal of general virology 88 , 450-7. doi:10.1099/vir.0.82396-0

Argaud, O., Croizier, L., López-Ferber, M., Croizier, G., 1998. Two key mutations in the host-range specificity domain of the p143 gene of Autographa californica nucleopolyhedrovirus are required to kill Bombyx mori larvae. The Journal of general virology 79 ( $\mathrm{Pt} 4), 931-5$. doi:10.1099/00221317-79-4-931

Argaud, O., Lopez-Ferber, M., Croizier, L., Croizier, G., 1998. Two key mutations in the host-range specificity domain of the p143 gene of Autographa californica nucleopolyhedrovirus are required to kill Bombyx mori larvae. Journal of General Virology 79, 931-935. doi:10.1099/0022-1317-79$4-931$

Asgari, S., Schmidt, O., 2001. Promoter studies of a polydnavirus gene from Cotesia rubecula (Hym: Braconidae). Archives of virology 146, 1979-89.

Asgari, S., 2006. Venom proteins from polydnavirus-producing endoparasitoids: their role in host-parasite interactions. Archives of insect biochemistry and physiology 61, 146-56. doi:10.1002/arch.20109

Ashour, M.-B., Ragheb, D.A., El-Sheikh, E.-S.A., Gomaa, E.-A.A., Kamita, S.G., Hammock, B.D., 2007. Biosafety of recombinant and wild type nucleopolyhedroviruses as bioinsecticides. International journal of environmental research and public health 4, 111-25. 
Asser-Kaiser, S., Radtke, P., El-Salamouny, S., Winstanley, D., Jehle, J.A., 2011. Baculovirus resistance in codling moth (Cydia pomonella L.) caused by early block of virus replication. Virology 410 , 360-7. doi:10.1016/j.virol.2010.11.021

Ayres, M.D., Howard, S.C., Kuzio, J., Lopez-Ferber, M., Possee, R.D., 1994. The complete DNA sequence of Autographa californica nuclear polyhedrosis virus. Virology 202, 586-605. doi:10.1006/viro.1994.1380

Barat-Houari, M., Hilliou, F., Jousset, F.-X., Sofer, L., Deleury, E., Rocher, J., Ravallec, M., Galibert, L., Delobel, P., Feyereisen, R., Fournier, P., Volkoff, A.-N., 2006. Gene expression profiling of Spodoptera frugiperda hemocytes and fat body using cDNA microarray reveals polydnavirusassociated variations in lepidopteran host genes transcript levels. BMC genomics 7, 160 doi:10.1186/1471-2164-7-160

Beck, M.H., Strand, M.R., 2007. A novel polydnavirus protein inhibits the insect prophenoloxidase activation pathway. Proceedings of the National Academy of Sciences of the United States of America 104, 19267-72. doi:10.1073/pnas.0708056104

Beniya, H., Funk, C.J., Rohrmann, G.F., Weaver, R.F., 1996. Purification of a virus-induced RNA polymerase from Autographa californica nuclear polyhedrosis virus-infected Spodoptera frugiperda cells that accurately initiates late and very late transcription in vitro. Virology 216, 12-9. doi:10.1006/viro.1996.0029

Bézier, A., Annaheim, M., Herbinière, J., Wetterwald, C., Gyapay, G., Bernard-Samain, S., Wincker, P., Roditi, I., Heller, M., Belghazi, M., Pfister-Wilhem, R., Periquet, G., Dupuy, C., Huguet, E., Volkoff, A.-N., Lanzrein, B., Drezen, J.-M., 2009. Polydnaviruses of braconid wasps derive from an ancestral nudivirus. Science (New York, N.Y.) 323, 926-30. doi:10.1126/science.1166788

Bézier, A., Herbinière, J., Lanzrein, B., Drezen, J.-M., 2009. Polydnavirus hidden face: the genes producing virus particles of parasitic wasps. Journal of invertebrate pathology 101, 194-203. doi:10.1016/j.jip.2009.04.006

Blagborough, A.M., Yoshida, S., Sattabongkot, J., Tsuboi, T., Sinden, R.E., 2010. Intranasal and intramuscular immunization with Baculovirus Dual Expression System-based Pvs25 vaccine substantially blocks Plasmodium vivax transmission. Vaccine 28, 6014-20. doi:10.1016/j.vaccine.2010.06.100

Blissard, G.W., Rohrmann, G.F., 1989. Location, sequence, transcriptional mapping, and temporal expression of the gp64 envelope glycoprotein gene of the Orgyia pseudotsugata multicapsid nuclear polyhedrosis virus. Virology 170, 537-55.

Blissard, G.W., Rohrmann, G.F., 1991. Baculovirus gp64 gene expression: analysis of sequences modulating early transcription and transactivation by IE1. Journal of virology 65, 5820-7.

Boffa, L.C., Gruss, R.J., Allfrey, V.G., 1981. Manifold effects of sodium butyrate on nuclear function. Selective and reversible inhibition of phosphorylation of histones H1 and H2A and impaired methylation of lysine and arginine residues in nuclear protein fractions. The Journal of biological chemistry $256,9612-21$.

Bonning, B.C., Hoover, K., Duffey, S., Hammock, B.D., 1995. Production of Polyhedra of the Autographa californica Nuclear Polyhedrosis Virus Using the Sf21 and Tn5B1-4 Cell Lines and Comparison with Host-Derived Polyhedra by Bioassay. Journal of Invertebrate Pathology 66, 224230. doi:10.1006/jipa.1995.1093

Borodina, T.A., Lehrach, H., Soldatov, A. V, 2003. DNA purification on homemade silica spin-columns. Analytical biochemistry 321, 135-7. 
Breitenbach, J.E., Shelby, K.S., Popham, H.J.R., 2011. Baculovirus induced transcripts in hemocytes from the larvae of Heliothis virescens. Viruses 3, 2047-64. doi:10.3390/v3112047

Burke, G.R., Burke, G., Strand, M., Quicke, D., Lawrence, P., Pichon, A., Bézier, A., Urbach, S., Aury, J., Jouan, V., Ravallec, M., Webb, B., Strand, M., 2016. Analysis of Genetic Variation across the Encapsidated Genome of Microplitis demolitor Bracovirus in Parasitoid Wasps. PLOS ONE 11, e0158846. doi:10.1371/journal.pone.0158846

Burke, G.R., Strand, M.R., 2012. Deep sequencing identifies viral and wasp genes with potential roles in replication of Microplitis demolitor Bracovirus. Journal of virology 86, 3293-306. doi:10.1128/JVI.06434-11

Burke, G.R., Strand, M.R., 2014. Systematic analysis of a wasp parasitism arsenal. Molecular ecology 23, 890-901. doi:10.1111/mec.12648

Burke, G.R., Thomas, S.A., Eum, J.H., Strand, M.R., 2013. Mutualistic polydnaviruses share essential replication gene functions with pathogenic ancestors. PLoS pathogens 9, e1003348. doi:10.1371/journal.ppat.1003348

Burke, G.R., Walden, K.K.O., Whitfield, J.B., Robertson, H.M., Strand, M.R., 2014. Widespread genome reorganization of an obligate virus mutualist. PLoS genetics 10, e1004660. doi:10.1371/journal.pgen.1004660

Carpes, M.P., de Castro, M.E.B., Soares, E.F., Villela, A.G., Pinedo, F.J.R., Ribeiro, B.M., 2005. The inhibitor of apoptosis gene (iap-3) of Anticarsia gemmatalis multicapsid nucleopolyhedrovirus (AgMNPV) encodes a functional IAP. Archives of virology 150, 1549-62. doi:10.1007/s00705005-0529-6

Castro, M.E., Souza, M.L., Araujo, S., Bilimoria, S.L., 1997. Replication of Anticarsia gemmatalis nuclear polyhedrosis virus in four lepidopteran cell lines. Journal of invertebrate pathology 69,40 5. doi:10.1006/jipa.1996.4624

Castro, M.E., Souza, M.L., Bilimoria, S.L., 1999. Host-specific transcription of nucleopolyhedrovirus gene homologues in productive and abortive Anticarsia gemmatalis MNPV infections. Archives of virology 144, 1111-21.

Castro, M.E.B., Ribeiro, Z.M.A., Souza, M.L., 2006. Infectivity of Anticarsia gemmatalis nucleopolyhedrovirus to different insect cell lines: Morphology, viral production, and protein synthesis. Biological Control 36, 299-304. doi:10.1016/j.biocontrol.2005.10.002

Chang, M.J., Blissard, G.W., 1997. Baculovirus gp64 gene expression: negative regulation by a minicistron. Journal of virology $71,7448-60$.

Chen, Y.-R., Zhong, S., Fei, Z., Hashimoto, Y., Xiang, J.Z., Zhang, S., Blissard, G.W., 2013. The transcriptome of the baculovirus Autographa californica multiple nucleopolyhedrovirus in Trichoplusia ni cells. Journal of virology 87, 6391-405. doi:10.1128/JVI.00194-13

Chevignon, G., Thézé, J., Cambier, S., Poulain, J., Da Silva, C., Bézier, A., Musset, K., Moreau, S.J.M., Drezen, J.-M., Huguet, E., 2014. Functional annotation of Cotesia congregata bracovirus: identification of viral genes expressed in parasitized host immune tissues. Journal of virology 88 , 8795-812. doi:10.1128/JVI.00209-14

Chikhalya, A., Luu, D.D., Carrera, M., De La Cruz, A., Torres, M., Martinez, E.N., Chen, T., Stephens, K.D., Haas-Stapleton, E.J., 2009. Pathogenesis of Autographa californica multiple nucleopolyhedrovirus in fifth-instar Anticarsia gemmatalis larvae. Journal of General Virology 90, 2023-2032. doi:10.1099/vir.0.011718-0 
Chikhalya, A., Luu, D.D., Carrera, M., De La Cruz, A., Torres, M., Martinez, E.N., Chen, T., Stephens, K.D., Haas-Stapleton, E.J., 2009. Pathogenesis of Autographa californica multiple nucleopolyhedrovirus in fifth-instar Anticarsia gemmatalis larvae. The Journal of general virology 90, 2023-32. doi:10.1099/vir.0.011718-0

Choi, J., Guarino, L.A., 1995. Expression of the IE1 transactivator of Autographa californica nuclear polyhedrosis virus during viral infection. Virology 209, 99-107.

Choi, J.Y., Roh, J.Y., Wang, Y., Zhen, Z., Tao, X.Y., Lee, J.H., Liu, Q., Kim, J.S., Shin, S.W., Je, Y.H., 2012. Analysis of Genes Expression of Spodoptera exigua Larvae upon AcMNPV Infection. PLoS ONE 7, e42462. doi:10.1371/journal.pone.0042462

Clem, R.J., Miller, L.K., 1993. Apoptosis reduces both the in vitro replication and the in vivo infectivity of a baculovirus. Journal of virology $67,3730-8$.

Clem, R.J., 2007. Baculoviruses and apoptosis: a diversity of genes and responses. Current drug targets 8 , 1069-74.

Condreay, J.P., Witherspoon, S.M., Clay, W.C., Kost, T.A., 1999. Transient and stable gene expression in mammalian cells transduced with a recombinant baculovirus vector. Proceedings of the National Academy of Sciences of the United States of America 96, 127-32.

Contreras-Leal, E., Hernández-Oliveras, A., Flores-Peredo, L., Zarain-Herzberg, Á., Santiago-García, J., 2016. Histone deacetylase inhibitors promote the expression of ATP2A3 gene in breast cancer cell lines. Molecular Carcinogenesis 55, 1477-1485. doi:10.1002/mc.22402

Cordeiro, B.A., Tibúrcio, V.H.S., Hallwass, M., Paes, H.C., Ribeiro, B.M., Báo, S.N., 2008. Structural and ultrastructural alterations of Malpighian tubules of Anticarsia gemmatalis (Hübner) (Lepidoptera: Noctuidae) larvae infected with different Anticarsia gemmatalis multiple nucleopolyhedrovirus (AgMNPV) recombinant viruses. Journal of invertebrate pathology 98, 7-19. doi:10.1016/j.jip.2008.01.001

Cory, J.S., Franklin, M.T., 2012. Evolution and the microbial control of insects. Evolutionary applications 5, 455-69. doi:10.1111/j.1752-4571.2012.00269.x

Coulibaly, F., Chiu, E., Gutmann, S., Rajendran, C., Haebel, P.W., Ikeda, K., Mori, H., Ward, V.K., Schulze-Briese, C., Metcalf, P., 2009. The atomic structure of baculovirus polyhedra reveals the independent emergence of infectious crystals in DNA and RNA viruses. Proceedings of the National Academy of Sciences of the United States of America 106, 22205-10. doi:10.1073/pnas.0910686106

Cui, L., Soldevila, A., Webb, B., 2000. Relationships between polydnavirus gene expression and host range of the parasitoid wasp Campoletis sonorensis. Journal of insect physiology 46, 1397-1407.

Danquah, J.O., Botchway, S., Jeshtadi, A., King, L.A., 2012. Direct interaction of baculovirus capsid proteins VP39 and EXON0 with kinesin-1 in insect cells determined by fluorescence resonance energy transfer-fluorescence lifetime imaging microscopy. Journal of virology 86, 844-53. doi:10.1128/JVI.06109-11

Danyluk, G.M., Maruniak, J.E., 1987. In vivo and in vitro host range of Autographa californica nuclear polyhedrosis virus and Spodoptera frugiperda nuclear polyhedrosis virus. Journal of invertebrate pathology 50, 207-12.

Davies, D.H., Vinson, S.B., 1988. Interference with function of plasmatocytes of Heliothis virescens in vivo by calyx fluid of the parasitoid Campoletis sonorensis. Cell and tissue research 251, 467-75. 
de Castro, M.E., Ribeiro, B.M., 2001. Production of viral progeny in insect cells undergoing apoptosis induced by a mutant Anticarsia gemmatalis nucleopolyhedrovirus. Microbiological research 156, 369-76. doi:10.1078/0944-5013-00122

de Jong, J.G., Lauzon, H.A.M., Dominy, C., Poloumienko, A., Carstens, E.B., Arif, B.M., Krell, P.J., 2005. Analysis of the Choristoneura fumiferana nucleopolyhedrovirus genome. The Journal of general virology 86, 929-43. doi:10.1099/vir.0.80490-0

de Lima, L., Pinedo, F.J.R., Ribeiro, B.M., Zanotto, P.M.A., Wolff, J.L.C., 2004. Identification, expression and phylogenetic analysis of the Anticarsia gemmatalis multicapsid nucleopolyhedrovirus (AgMNPV) Helicase gene. Virus genes 29, 345-52. doi:10.1007/s11262004-7438-8

de Oliveira, V.C., da Silva Morgado, F., Ardisson-Araújo, D.M.P., Resende, R.O., Ribeiro, B.M., 2015. The silencing suppressor (NSs) protein of the plant virus Tomato spotted wilt virus enhances heterologous protein expression and baculovirus pathogenicity in cells and lepidopteran insects. Archives of Virology 160, 2873-2879. doi:10.1007/s00705-015-2580-2

Dolz-Edo, L., Rienzo, A., Poveda-Huertes, D., Pascual-Ahuir, A., Proft, M., 2013. Deciphering dynamic dose responses of natural promoters and single cis elements upon osmotic and oxidative stress in yeast. Molecular and cellular biology 33, 2228-40. doi:10.1128/MCB.00240-13

Drezen, J.-M., Provost, B., Espagne, E., Cattolico, L., Dupuy, C., Poirié, M., Periquet, G., Huguet, E., 2003. Polydnavirus genome: integrated vs. free virus. Journal of insect physiology 49, 407-17.

Du, X., Thiem, S.M., 1997. Responses of insect cells to baculovirus infection: protein synthesis shutdown and apoptosis. Journal of virology 71, 7866-72.

Du, X., Thiem, S.M., 1997. Characterization of Host Range Factor 1 (hrf-1) Expression inLymantria disparM Nucleopolyhedrovirus- and RecombinantAutographa californica $\mathrm{M}$ Nucleopolyhedrovirus-Infected IPLB-Ld652Y Cells. Virology 227, 420-430. doi:10.1006/viro.1996.8356

Dupas, S., Gitau, C.W., Branca, A., Le Rü, B.P., Silvain, J.-F., 2008. Evolution of a polydnavirus gene in relation to parasitoid-host species immune resistance. The Journal of heredity 99, 491-9. doi:10.1093/jhered/esn047

Dupuy, C., Huguet, E., Drezen, J.-M., 2006. Unfolding the evolutionary story of polydnaviruses. Virus research 117, 81-9. doi:10.1016/j.virusres.2006.01.001

Engelhard, E.K., Kam-Morgan, L.N., Washburn, J.O., Volkman, L.E., 1994. The insect tracheal system: a conduit for the systemic spread of Autographa californica M nuclear polyhedrosis virus. Proceedings of the National Academy of Sciences of the United States of America 91, 3224-7.

Engelhard, E.K., Volkman, L.E., 1995. Developmental resistance in fourth instar Trichoplusia ni orally inoculated with Autographa californica M nuclear polyhedrosis virus. Virology 209, 384-9. doi:10.1006/viro.1995.1270

Fernández-Triana, J.L., 2010. Eight new species and an annotated checklist of Microgastrinae (Hymenoptera, Braconidae) from Canada and Alaska. ZooKeys 1-53. doi:10.3897/zookeys.63.565

Fickenscher, H., Stamminger, T., Rüger, R., Fleckenstein, B., 1989. The role of a repetitive palindromic sequence element in the human cytomegalovirus major immediate early enhancer. The Journal of general virology 70 ( Pt 1), 107-23.

Funk, C.J., Harwood, S.H., Rohrmann, G.F., 1998. Differential stability of baculovirus late transcription complexes during initiation and elongation. Virology 241, 131-40. doi:10.1006/viro.1997.8961 
Fuxa, J., Richter, A., 1998. Repeated reversion of resistance to nucleopolyhedrovirus by Anticarsia gemmatalis. Journal of invertebrate pathology 71, 159-64. doi:10.1006/jipa.1997.4724

Gallo, L.G., Corsaro, B.G., Hughes, P.R., Granados, R.R., 1991. In vivo enhancement of baculovirus infection by the viral enhancing factor of a granulosis virus of the cabbage looper, Trichoplusia $n i$ (Lepidoptera: Noctuidae). Journal of Invertebrate Pathology 58, 203-210. doi:10.1016/00222011(91)90064-W

Gao, H., Wang, Y., Li, N., Peng, W.-P., Sun, Y., Tong, G.-Z., Qiu, H.-J., 2007. Efficient gene delivery into mammalian cells mediated by a recombinant baculovirus containing a whispovirus ie 1 promoter, a novel shuttle promoter between insect cells and mammalian cells. Journal of biotechnology 131, 138-43. doi:10.1016/j.jbiotec.2007.06.002

Garrity, D.B., Chang, M.J., Blissard, G.W., 1997. Late promoter selection in the baculovirus gp64 envelope fusion protein gene. Virology 231, 167-81. doi:10.1006/viro.1997.8540

Ghosh, S., Jain, A., Mukherjee, B., Habib, S., Hasnain, S.E., 1998. The host factor polyhedrin promoter binding protein (PPBP) is involved in transcription from the baculovirus polyhedrin gene promoter. Journal of virology 72, 7484-93.

Ghosh, S., Parvez, M.K., Banerjee, K., Sarin, S.K., Hasnain, S.E., 2002. Baculovirus as mammalian cell expression vector for gene therapy: an emerging strategy. Molecular therapy: the journal of the American Society of Gene Therapy 6, 5-11.

Glocker, B., Hoopes, R.R., Hodges, L., Rohrmann, G.F., 1993. In vitro transcription from baculovirus late gene promoters: accurate mRNA initiation by nuclear extracts prepared from infected Spodoptera frugiperda cells. Journal of virology 67, 3771-6.

Glocker, B., Hoopes, R.R., Rohrmann, G.F., 1992. In vitro transactivation of baculovirus early genes by nuclear extracts from Autographa californica nuclear polyhedrosis virus-infected Spodoptera frugiperda cells. Journal of virology 66, 3476-84.

Goodwin, R.H., Tompkins, G.J., McCawley, P., 1978. Gypsy moth cell lines divergent in viral susceptibility. I. Culture and identification. In vitro 14, 485-94.

Grace, T.D., 1967. Establishment of a line of cells from the silkworm Bombyx mori. Nature 216, 613.

Granados, R.R., Guoxun, L., Derksen, A.C.G., McKenna, K.A., 1994. A new insect cell line from Trichoplusia ni (BTI-Tn-5B1-4) susceptible to Trichoplusia ni single enveloped nuclear polyhedrosis virus. Journal of Invertebrate Pathology 64, 260-266. doi:10.1016/S00222011(94)90400-6

Grasela, J.J., McIntosh, A.H., 1998. In vitro and in vivo host range of Anticarsia gemmatalis multiple nuclear polyhedrosis virus. In vitro cellular \& developmental biology. Animal 34, 79-83. doi:10.1007/s11626-998-0057-2

Gross, C.H., Russell, R.L., Rohrmann, G.F., 1994. Orgyia pseudotsugata baculovirus p10 and polyhedron envelope protein genes: analysis of their relative expression levels and role in polyhedron structure. The Journal of general virology 75 ( Pt 5), 1115-23.

Gruber, A., Stettler, P., Heiniger, P., Schümperli, D., Lanzrein, B., 1996. Polydnavirus DNA of the braconid wasp Chelonus inanitus is integrated in the wasp's genome and excised only in later pupal and adult stages of the female. The Journal of general virology 77 ( Pt 11, 2873-9.

Guarino, L.A., Xu, B., Jin, J., Dong, W., 1998. A virus-encoded RNA polymerase purified from baculovirus-infected cells. Journal of virology 72, 7985-91. 
Guzo, D., Rathburn, H., Guthrie, K., Dougherty, E., 1992. Viral and host cellular transcription in Autographa californica nuclear polyhedrosis virus-infected gypsy moth cell lines. Journal of virology 66, 2966-72.

Haase, S., Sciocco-Cap, A., Romanowski, V., 2015. Baculovirus insecticides in Latin America: historical overview, current status and future perspectives. Viruses 7, 2230-2267. doi:10.3390/v7052230

Haas-Stapleton, E.J., Washburn, J.O., Volkman, L.E., 2005. Spodoptera frugiperda resistance to oral infection by Autographa californica multiple nucleopolyhedrovirus linked to aberrant occlusionderived virus binding in the midgut. The Journal of general virology 86, 1349-55. doi:10.1099/vir.0.80845-0

Harrison, R.L., Jarvis, D.L., Summers, M.D., 1996. The Role of the AcMNPV 25KGene, "FP25," in Baculoviruspolhandp10Expression. Virology 226, 34-46. doi:10.1006/viro.1996.0625

Hasnain, S.E., Nakhai, B., 1990. Expression of the gene encoding firefly luciferase in insect cells using a baculovirus vector. Gene 91, 135-8.

Hefferon, K.L., Miller, L.K., 2002. Reconstructing the replication complex of AcMNPV. European journal of biochemistry 269, 6233-40.

Herniou, E.A., Olszewski, J.A., O’Reilly, D.R., Cory, J.S., 2004. Ancient coevolution of baculoviruses and their insect hosts. Journal of virology 78, 3244-51.

Hoopes, R.R., Rohrmann, G.F., 1991. In vitro transcription of baculovirus immediate early genes: accurate mRNA initiation by nuclear extracts from both insect and human cells. Proceedings of the National Academy of Sciences of the United States of America 88, 4513-7.

Horton, H.M., Burand, J.P., 1993. Saturable attachment sites for polyhedron-derived baculovirus on insect cells and evidence for entry via direct membrane fusion. Journal of virology 67, 1860-8.

Hou, D., Zhang, L., Deng, F., Fang, W., Wang, R., Liu, X., Guo, L., Rayner, S., Chen, X., Wang, H., Hu, Z., 2012. Comparative Proteomics Reveal Fundamental Structural and Functional Differences between the Two Progeny Phenotypes of a Baculovirus. Journal of virology. doi:10.1128/JVI.02329-12

Hu, Y.C., Bentley, W.E., 2001. Effect of MOI ratio on the composition and yield of chimeric infectious bursal disease virus-like particles by baculovirus co-infection: deterministic predictions and experimental results. Biotechnology and bioengineering 75, 104-19.

Huynh, H.T., Tran, T.T.B., Chan, L.C.L., Nielsen, L.K., Reid, S., 2013. Decline in baculovirus-expressed recombinant protein production with increasing cell density is strongly correlated to impairment of virus replication and mRNA expression. Applied microbiology and biotechnology 97, 5245-57. doi:10.1007/s00253-013-4835-8

Igarashi, A., 1978. Isolation of a Singh's Aedes albopictus cell clone sensitive to Dengue and Chikungunya viruses. The Journal of general virology 40, 531-44.

Ikeda, M., Yamada, H., Hamajima, R., Kobayashi, M., 2013. Baculovirus genes modulating intracellular innate antiviral immunity of lepidopteran insect cells. Virology 435, 1-13. doi:10.1016/j.virol.2012.10.016

Ishikawa, H., Ikeda, M., Yanagimoto, K., Alves, C.A.F., Katou, Y., Laviña-Caoili, B.A., Kobayashi, M., 2003. Induction of apoptosis in an insect cell line, IPLB-Ld652Y, infected with nucleopolyhedroviruses. The Journal of general virology 84, 705-14. doi:10.1099/vir.0.18815-0 
Ishiyama, S., Ikeda, M., 2010. High-level expression and improved folding of proteins by using the vp39 late promoter enhanced with homologous DNA regions. Biotechnology letters 32, 1637-47. doi:10.1007/s10529-010-0340-7

Iwanaga, M., Takaya, K., Katsuma, S., Ote, M., Tanaka, S., Kamita, S.G., Kang, W., Shimada, T., Kobayashi, M., 2004. Expression profiling of baculovirus genes in permissive and nonpermissive cell lines. Biochemical and Biophysical Research Communications 323, 599-614. doi:10.1016/j.bbrc.2004.08.114

Iwanaga, M., Takaya, K., Katsuma, S., Ote, M., Tanaka, S., Kamita, S.G., Kang, W., Shimada, T., Kobayashi, M., 2004. Expression profiling of baculovirus genes in permissive and nonpermissive cell lines. Biochemical and biophysical research communications 323, 599-614. doi:10.1016/j.bbrc.2004.08.114

Jarvis, D.L., Garcia, A., 1994. Biosynthesis and processing of the Autographa californica nuclear polyhedrosis virus gp64 protein. Virology 205, 300-13. doi:10.1006/viro.1994.1646

Jarvis, D.L., Weinkauf, C., Guarino, L.A., 1996. Immediate-early baculovirus vectors for foreign gene expression in transformed or infected insect cells. Protein expression and purification 8, 191-203. doi:10.1006/prep.1996.0092

Jehle, J.A., Blissard, G.W., Bonning, B.C., Cory, J.S., Herniou, E.A., Rohrmann, G.F., Theilmann, D.A., Thiem, S.M., Vlak, J.M., 2006. On the classification and nomenclature of baculoviruses: a proposal for revision. Archives of virology 151, 1257-66. doi:10.1007/s00705-006-0763-6

Jha, P.K., Nakhai, B., Sridhar, P., Talwar, G.P., Hasnain, S.E., 1990. Firefly luciferase, synthesized to very high levels in caterpillars infected with a recombinant baculovirus, can also be used as an efficient reporter enzyme in vivo. FEBS letters 274, 23-6.

Ji, X., Sutton, G., Evans, G., Axford, D., Owen, R., Stuart, D.I., 2010. How baculovirus polyhedra fit square pegs into round holes to robustly package viruses. The EMBO journal 29, 505-14. doi:10.1038/emboj.2009.352

Jiang, S.S., Chang, I.-S., Huang, L.-W., Chen, P.-C., Wen, C.-C., Liu, S.-C., Chien, L.-C., Lin, C.-Y., Hsiung, C.A., Juang, J.-L., 2006. Temporal transcription program of recombinant Autographa californica multiple nucleopolyhedrosis virus. Journal of virology 80, 8989-99. doi:10.1128/JVI.01158-06

Johnson, D.W., Maruniak, J.E., 1989. Physical Map of Anticarsia gemmatalis Nuclear Polyhedrosis Virus (AgMNPV-2) DNA. Journal of General Virology 70, 1877-1883. doi:10.1099/0022-1317-70-71877

Kato, T., Manohar, S.L., Kanamasa, S., Ogata, M., Park, E.Y., 2012. Improvement of the transcriptional strength of baculovirus very late polyhedrin promoter by repeating its untranslated leader sequences and coexpression with the primary transactivator. Journal of bioscience and bioengineering 113 , 694-6. doi:10.1016/j.jbiosc.2012.01.010

Katsuma, S., Kang, W., Shin-i, T., Ohishi, K., Kadota, K., Kohara, Y., Shimada, T., 2011. Mass identification of transcriptional units expressed from the Bombyx mori nucleopolyhedrovirus genome. The Journal of general virology 92, 200-3. doi:10.1099/vir.0.025908-0

Kawasaki, Y., Matsumoto, S., Nagamine, T., 2004. Analysis of baculovirus IE1 in living cells: dynamics and spatial relationships to viral structural proteins. The Journal of general virology $85,3575-3583$.

Kenoutis, C., Efrose, R.C., Swevers, L., Lavdas, A.A., Gaitanou, M., Matsas, R., Iatrou, K., 2006. Baculovirus-mediated gene delivery into Mammalian cells does not alter their transcriptional and differentiating potential but is accompanied by early viral gene expression. Journal of virology 80 , 4135-46. doi:10.1128/JVI.80.8.4135-4146.2006 
Kim, N.Y., Baek, J.Y., Choi, H.S., Chung, I.S., Shin, S., Lee, J.I., Choi, J.Y., Yang, J.M., 2012. Shorthairpin RNA-mediated gene expression interference in Trichoplusia ni cells. Journal of microbiology and biotechnology $22,190-8$.

Kogan, P.H., Chen, X., Blissard, G.W., 1995. Overlapping TATA-dependent and TATA-independent early promoter activities in the baculovirus gp64 envelope fusion protein gene. Journal of virology $69,1452-61$.

Kojima, K., Hayakawa, T., Asano, S., Bando, H., 2001. Tandem repetition of baculovirus ie1 promoter results in upregulation of transcription. Archives of virology 146, 1407-14.

Kool, M., Ahrens, C.H., Goldbach, R.W., Rohrmann, G.F., Vlak, J.M., 1994. Identification of genes involved in DNA replication of the Autographa californica baculovirus. Proceedings of the National Academy of Sciences of the United States of America 91, 11212-6.

Kost, T.A., Condreay, J.P., 1999. Recombinant baculoviruses as expression vectors for insect and mammalian cells. Current opinion in biotechnology 10, 428-33.

Kovacs, G.R., Guarino, L.A., Graham, B.L., Summers, M.D., 1991. Identification of spliced baculovirus RNAs expressed late in infection. Virology 185, 633-43.

Kroemer, J.A., Webb, B.A., 2004. Polydnavirus genes and genomes: emerging gene families and new insights into polydnavirus replication. Annual review of entomology 49, 431-56. doi:10.1146/annurev.ento.49.072103.120132

LaCount, D.J., Friesen, P.D., 1997. Role of early and late replication events in induction of apoptosis by baculoviruses. Journal of virology 71, 1530-7.

Lauzon, H.A.M., Jamieson, P.B., Krell, P.J., Arif, B.M., 2005. Gene organization and sequencing of the Choristoneura fumiferana defective nucleopolyhedrovirus genome. The Journal of general virology 86, 945-61. doi:10.1099/vir.0.80489-0

Leisy, D.J., Rasmussen, C., Owusu, E.O., Rohrmann, G.F., 1997. A mechanism for negative gene regulation in Autographa californica multinucleocapsid nuclear polyhedrosis virus. Journal of virology 71, 5088-94.

Leisy, D., Rohrmann, G., Beaudreau, G., 1986. The nucleotide sequence of the polyhedrin gene region from the multicapsid baculovirus of Orgyia pseudotsugata. Virology 153, 280-8.

Levy, S.M., Falleiros, A.M.F., Moscardi, F., Gregório, E.A., 2011. The role of peritrophic membrane in the resistance of Anticarsia gemmatalis larvae (Lepidoptera: Noctuidae) during the infection by its nucleopolyhedrovirus (AgMNPV). Arthropod structure \& development 40, 429-34. doi:10.1016/j.asd.2011.05.003

Levy, S.M., Moscardi, F., Falleiros, A.M.F., Silva, R.J., Gregório, E.A., 2009. A morphometric study of the midgut in resistant and non-resistant Anticarsia gemmatalis (Hübner) (Lepidoptera: Noctuidae) larvae to its nucleopolyhedrovirus (AgMNPV). Journal of invertebrate pathology 101, 17-22. doi:10.1016/j.jip.2009.02.010

Liu, C.Y.Y., Wang, C.H., Wang, J.C., Chao, Y.C., 2007. Stimulation of baculovirus transcriptome expression in mammalian cells by baculoviral transcriptional activators. The Journal of general virology 88, 2176-84. doi:10.1099/vir.0.82664-0

Liu, C.Y.-Y., Wang, C.-H., Hsiao, W.-K., Lo, H.-R., Wu, C.P., Chao, Y.C., 2009. RING and coiled-coil domains of baculovirus IE2 are critical in strong activation of the cytomegalovirus major immediate-early promoter in mammalian cells. Journal of virology 83, 3604-16.

doi:10.1128/JVI.01778-08 
Liu, G., Carstens, E.B., 1999. Site-directed mutagenesis of the AcMNPV p143 gene: effects on baculovirus DNA replication. Virology 253, 125-36. doi:10.1006/viro.1998.9485

Liu, Y., Chu, C., Wu, T., 2006. Baculovirus ETL promoter acts as a shuttle promoter between insect cells and mammalian cells. Acta pharmacologica Sinica 27, 321-7. doi:10.1111/j.17457254.2006.00276.x

Lo, H.-R., Chou, C.-C., Wu, T.-Y., Yuen, J.P.-Y., Chao, Y.-C., 2002. Novel baculovirus DNA elements strongly stimulate activities of exogenous and endogenous promoters. The Journal of biological chemistry 277, 5256-64. doi:10.1074/jbc.M108895200

Lu, A., Carstens, E.B., 1991. Nucleotide sequence of a gene essential for viral DNA replication in the baculovirus Autographa californica nuclear polyhedrosis virus. Virology 181, 336-47.

Luckow, V.A., Lee, S.C., Barry, G.F., Olins, P.O., 1993. Efficient generation of infectious recombinant baculoviruses by site-specific transposon-mediated insertion of foreign genes into a baculovirus genome propagated in Escherichia coli. Journal of virology 67, 4566-79.

Lynn, D.E., 2003. Comparative susceptibilities of twelve insect cell lines to infection by three baculoviruses. Journal of Invertebrate Pathology 82, 129-131. doi:10.1016/S0022-2011(03)000028

Manohar, S.L., Kanamasa, S., Nishina, T., Kato, T., Park, E.Y., 2010. Enhanced gene expression in insect cells and silkworm larva by modified polyhedrin promoter using repeated Burst sequence and very late transcriptional factor-1. Biotechnology and bioengineering 107, 909-16. doi:10.1002/bit.22896

Markiewicz, M., Smith, E.A., Rubinchik, S., Dong, J.Y., Trojanowska, M., LeRoy, E.C.,. The 72kilodalton IE-1 protein of human cytomegalovirus (HCMV) is a potent inducer of connective tissue growth factor (CTGF) in human dermal fibroblasts. Clinical and experimental rheumatology 22, S31-4.

McIntosh, A.H., Grasela, J.J., Popham, H.J.R.,. AcMNPV in permissive, semipermissive, and nonpermissive cell lines from Arthropoda. In vitro cellular \& developmental biology. Animal 41, 298-304. doi:10.1290/0412083R.1

Mehrabadi, M., Hussain, M., Matindoost, L., Asgari, S., 2015. The Baculovirus Antiapoptotic p35 Protein Functions as an Inhibitor of the Host RNA Interference Antiviral Response. Journal of virology 89, 8182-92. doi:10.1128/JVI.00802-15

Meier, J.L., Pruessner, J.A., 2000. The human cytomegalovirus major immediate-early distal enhancer region is required for efficient viral replication and immediate-early gene expression. Journal of virology $74,1602-13$

Micheloud, G.A., Gioria, V. V, Pérez, G., Claus, J.D., 2009. Production of occlusion bodies of Anticarsia gemmatalis multiple nucleopolyhedrovirus in serum-free suspension cultures of the saUFL-AG-286 cell line: influence of infection conditions and statistical optimization. Journal of virological methods 162, 258-66. doi:10.1016/j.jviromet.2009.08.021

Miele, S.A.B., Garavaglia, M.J., Belaich, M.N., Ghiringhelli, P.D., 2011. Baculovirus: molecular insights on their diversity and conservation. International journal of evolutionary biology 2011, 379424 . doi: $10.4061 / 2011 / 379424$

Miller, L.K., 1993. Baculoviruses: high-level expression in insect cells. Current opinion in genetics \& development 3, 97-101.

Miller, L., 1997. The Baculoviruses (Google eBook). Springer. 
Morris, T.D., Miller, L.K., 1993. Characterization of productive and non-productive AcMNPV infection in selected insect cell lines. Virology 197, 339-48. doi:10.1006/viro.1993.1595

Morris, T.D., Miller, L.K., 1994. Mutational analysis of a baculovirus major late promoter. Gene 140, 147-53.

Morris, T.D., Miller, L.K., 1992. Promoter influence on baculovirus-mediated gene expression in permissive and nonpermissive insect cell lines. Journal of virology 66, 7397-405.

Morris, T.D., Miller, L.K., 1993. Characterization of Productive and Non-productive AcMNPV Infection in Selected Insect Cell Lines. Virology 197, 339-348. doi:10.1006/viro.1993.1595

Moscardi, F., 1999. Assessment of the application of baculoviruses for control of Lepidoptera. Annual review of entomology 44, 257-89. doi:10.1146/annurev.ento.44.1.257

Mukherjee, B., Burma, S., Talwar, G.P., Hasnain, S.E., 1995. Transcriptional regulation of cell linedependent, baculovirus-mediated expression of foreign genes. DNA and cell biology 14, 7-14

Murhammer, D., 2007. Baculovirus and Insect Cell Expression Protocols (Methods in Molecular Biology). Humana Press.

Nagamine, T., Kawasaki, Y., Iizuka, T., Matsumoto, S., 2005. Focal distribution of baculovirus IE1 triggered by its binding to the hr DNA elements. Journal of virology 79, 39-46. doi:10.1128/JVI.79.1.39-46.2005

Norton, W.N., Vinson, S.B., 1983. Correlating the initiation of virus replication with a specific pupal developmental phase of an ichneumonid parasitoid. Cell and tissue research 231, 387-98.

Ohkawa, T., Volkman, L.E., Welch, M.D., 2010. Actin-based motility drives baculovirus transit to the nucleus and cell surface. The Journal of Cell Biology 190, 187-195.

Ohresser, M., Morin, N., Cerutti, M., Delsert, C., 1995. Sequence analysis and transcriptional mapping of the orf-2 gene of Autographa californica nuclear polyhedrosis virus. Gene 152, 201-4.

Oliveira, J.V. de C., Wolff, J.L.C., Garcia-Maruniak, A., Ribeiro, B.M., de Castro, M.E.B., de Souza, M.L., Moscardi, F., Maruniak, J.E., Zanotto, P.M. de A., 2006. Genome of the most widely used viral biopesticide: Anticarsia gemmatalis multiple nucleopolyhedrovirus. The Journal of general virology 87, 3233-50. doi:10.1099/vir.0.82161-0

Oliveira, V.C., Bartasson, L., de Castro, M.E.B., Corrêa, J.R., Ribeiro, B.M., Resende, R.O., 2011. A silencing suppressor protein (NSs) of a tospovirus enhances baculovirus replication in permissive and semipermissive insect cell lines. Virus Research 155, 259-267. doi:10.1016/j.virusres.2010.10.019

Passarelli, A.L., Miller, L.K., 1993. Identification and characterization of lef-1, a baculovirus gene involved in late and very late gene expression. Journal of virology $67,3481-8$.

Passarelli, A.L., 2011. Barriers to success: how baculoviruses establish efficient systemic infections. Virology 411, 383-92. doi:10.1016/j.virol.2011.01.009

Peng, Y., Li, K., Pei, R., Wu, C., Liang, C., Wang, Y., Chen, X., 2012. The protamine-like DNA-binding protein P6.9 epigenetically up-regulates Autographa californica multiple nucleopolyhedrovirus gene transcription in the late infection phase. Virologica Sinica 27, 57-68. doi:10.1007/s12250012-3229-x 
Pombo, V., Velloso, L., Ribeiro, B., Bao, S., 1998. Structural and ultrastructural changes during the infection of UFL-AG-286 cells with the baculovirus AgMNPV. Journal of invertebrate pathology $72,239-45$.

Power, J.F., Reid, S., Radford, K.M., Greenfield, P.F., Nielsen, L.K., 1994. Modeling and optimization of the baculovirus expression vector system in batch suspension culture. Biotechnology and bioengineering 44, 710-9. doi:10.1002/bit.260440607

Prikhod'ko, E.A., Miller, L.K., 1996. Induction of apoptosis by baculovirus transactivator IE1. Journal of virology $70,7116-24$.

Pullen, S.S., Friesen, P.D., 1995. The CAGT motif functions as an initiator element during early transcription of the baculovirus transregulator ie-1. Journal of virology $69,3575-83$.

Pullen, S.S., Friesen, P.D., 1995. Early transcription of the ie-1 transregulator gene of Autographa californica nuclear polyhedrosis virus is regulated by DNA sequences within its 5 ' noncoding leader region. Journal of virology 69, 156-65.

Rahman, M.M., Gopinathan, K.P., 2003. Analysis of host specificity of two closely related baculoviruses in permissive and nonpermissive cell lines. Virus Research 93, 13-23. doi:10.1016/S01681702(03)00046-7

Ramachandran, A., Jain, A., Arora, P., Bashyam, M.D., Chatterjee, U., Ghosh, S., Parnaik, V.K., Hasnain, S.E., 2001. Novel Sp family-like transcription factors are present in adult insect cells and are involved in transcription from the polyhedrin gene initiator promoter. The Journal of biological chemistry 276, 23440-9. doi:10.1074/jbc.M101537200

Rankin, C., Ooi, B.G., Miller, L.K., 1988. Eight base pairs encompassing the transcriptional start point are the major determinant for baculovirus polyhedrin gene expression. Gene 70, 39-49.

Rapp, J.C., Wilson, J.A., Miller, L.K., 1998. Nineteen baculovirus open reading frames, including LEF12, support late gene expression. Journal of virology 72, 10197-206.

Razuck, F.B., Ribeiro, B., Vargas, J.H., Wolff, J.L., Ribeiro, B.M., 2002. Characterization of the p10 gene region of Anticarsia gemmatalis nucleopolyhedrovirus. Virus genes 24, 243-7.

Reed, L.J., Muench, H., 1938. A simple method of estimating fifty per cent endpoints. Am. J. Epidemiol. 27, 493-497.

Ribeiro, B.M., Gatti, C.D., Costa, M.H., Moscardi, F., Maruniak, J.E., Possee, R.D., Zanotto, P.M., 2001. Construction of a recombinant Anticarsia gemmatalis nucleopolyhedrovirus (AgMNPV-2D) harbouring the beta-galactosidase gene. Archives of virology 146, 1355-67.

Ribeiro, B.M., Hutchinson, K., Miller, L.K., 1994. A mutant baculovirus with a temperature-sensitive IE1 transregulatory protein. Journal of virology $68,1075-84$.

Rice, W.C., Miller, L.K., 1986. Baculovirus transcription in the presence of inhibitors and in nonpermissive Drosophila cells. Virus Research 6, 155-172. doi:10.1016/0168-1702(86)90047-X

Rodas, V.M., Marques, F.H., Honda, M.T., Soares, D.M., Jorge, S.A.C., Antoniazzi, M.M., Medugno, C., Castro, M.E.B., Ribeiro, B.M., Souza, M.L., Tonso, A., Pereira, C.A., 2005. Cell Culture Derived AgMNPV Bioinsecticide: Biological Constraints and Bioprocess Issues. Cytotechnology 48, 27-39. doi:10.1007/s10616-005-3175-7

Rodems, S.M., Pullen, S.S., Friesen, P.D., 1997. DNA-dependent transregulation by IE1 of Autographa californica nuclear polyhedrosis virus: IE1 domains required for transactivation and DNA binding. Journal of virology 71, 9270-7. 
Rohrmann, G.F., 2013. Baculovirus Molecular Biology.

Roychoudhury, A., Basu, S., Sengupta, D.N., 2009. Analysis of comparative efficiencies of different transformation methods of $E$. coli using two common plasmid vectors. Indian journal of biochemistry \& biophysics $46,395-400$.

Russell, R.L., Pearson, M.N., Rohrmann, G.F., 1991. Immunoelectron microscopic examination of Orgyia pseudotsugata multicapsid nuclear polyhedrosis virus-infected Lymantria dispar cells: time course and localization of major polyhedron-associated proteins. The Journal of general virology 72 ( Pt 2), 275-83.

Salem, T.Z., Zhang, F., Xie, Y., Thiem, S.M., 2011. Comprehensive analysis of host gene expression in Autographa californica nucleopolyhedrovirus-infected Spodoptera frugiperda cells. Virology 412 , 167-78. doi:10.1016/j.virol.2011.01.006

Sambrook, J., 2001. Molecular Cloning: A Laboratory Manual, Third Edition (3 volume set). Cold Spring Harbor Laboratory Press.

Sambrook, J., Russell, D.W., 2001. Molecular Cloning - Sambrook \& Russel - Vol. 1, 2, 3.pdf, Human Mutation. Cold Spring Harbor Laboratory Press. doi:10.1002/humu.1186.abs

Schneider, I., 1972. Cell lines derived from late embryonic stages of Drosophila melanogaster. Journal of embryology and experimental morphology 27, 353-65.

Schultz, K.L.W., Friesen, P.D., 2009. Baculovirus DNA Replication-Specific Expression Factors Trigger Apoptosis and Shutoff of Host Protein Synthesis during Infection. Journal of Virology 83, 1112311132. doi:10.1128/JVI.01199-09

Shepard, M., Powell, J.E., Lones, W.A., 1983. Biology of Microplitis demolitor (Hymenoptera: Braconidae), an Imported Parasitoid of Heliothis (Lepidoptera: Noctuidae) spp. and the Soybean Looper, Pseudoplusia includens (Lepidoptera: Noctuidae). Environmental Entomology 641-645.

Shirina, T. V, Bobrovskaia, M.T., Kozlov, É.A.,. [The search of microRNA genes encoded in antiparallel chains of Autographa californica nuclear polyhedrosis virus genome regions, including most late and complementary genes]. Ukrainskiĭ biokhimicheskiǐ zhurnal 83, 41-9.

Sieburth, P.J., Maruniak, J.E., 1988. Growth characteristics of a continuous cell line from the velvetbean caterpillar,Anticarsia gemmatalis Hübner (Lepidoptera: Noctuidae). In Vitro Cellular \& Developmental Biology 24, 195-198. doi:10.1007/BF02623546

Singh, K.R.P., 1967. Cell cultures derived from larvae of Aedes albopictus (Skuse) and Aedes aegypti (L). Current Science 36, 506-508.

Slack, J.M., Blissard, G.W., 1997. Identification of two independent transcriptional activation domains in the Autographa californica multicapsid nuclear polyhedrosis virus IE1 protein. Journal of virology 71, 9579-87.

Slack, J.M., Kuzio, J., Faulkner, P., 1995. Characterization of v-cath, a cathepsin L-like proteinase expressed by the baculovirus Autographa californica multiple nuclear polyhedrosis virus. The Journal of general virology 76 (Pt 5), 1091-8. doi:10.1099/0022-1317-76-5-1091

Slack, J., Arif, B.M., 2007. The baculoviruses occlusion-derived virus: virion structure and function. Advances in virus research 69, 99-165. doi:10.1016/S0065-3527(06)69003-9

Slack, J.M., Ribeiro, B.M., de Souza, M.L., 2004. The gp64 locus of Anticarsia gemmatalis multicapsid nucleopolyhedrovirus contains a 3' repair exonuclease homologue and lacks v-cath and ChiA genes. The Journal of general virology 85, 211-9. 
Soares, J.S., Ribeiro, B.M., 2005. Pathology of Anticarsia gemmatalis larvae infected by two recombinant A. gemmatalis multicapsid nucleopolyhedroviruses. Research in microbiology 156, 263-9. doi:10.1016/j.resmic.2004.09.015

Sokal, N., Nie, Y., Willis, L.G., Yamagishi, J., Blissard, G.W., Rheault, M.R., Theilmann, D.A., 2014. Defining the roles of the baculovirus regulatory proteins IE0 and IE1 in genome replication and early gene transactivation. Virology 468-470, 160-71. doi:10.1016/j.virol.2014.07.044

Soldevila, A.I., Webb, B.A., 1996. Expression of polydnavirus genes under polydnavirus promoter regulation in insect larvae infected with baculovirus recombinants. Journal of General Virology 77 , 1379-1388. doi:10.1099/0022-1317-77-7-1379

Sriram, S., Palhan, V.B., Gopinathan, K.P., 1997. Heterologous promoter recognition leading to highlevel expression of cloned foreign genes in Bombyx mori cell lines and larvae. Gene 190, 181-9.

Strand, M.R., 1994. Microplitis demolitor polydnavirus infects and expresses in specific morphotypes of Pseudoplusia includens haemocytes. The Journal of general virology 75 (Pt 11, 3007-20.

Strand, M.R., Pech, L.L., 1995. Microplitis demolitor polydnavirus induces apoptosis of a specific haemocyte morphotype in Pseudoplusia includens. The Journal of general virology 76 (Pt 2), $283-$ 91.

Strand, M.R., Witherell, R.A., Trudeau, D., 1997. Two Microplitis demolitor polydnavirus mRNAs expressed in hemocytes of Pseudoplusia includens contain a common cysteine-rich domain. Journal of virology 71, 2146-56.

Strand, M.R., Beck, M.H., Lavine, M.D., Clark, K.D., 2006. Microplitis demolitor bracovirus inhibits phagocytosis by hemocytes from Pseudoplusia includens. Archives of insect biochemistry and physiology 61, 134-45. doi:10.1002/arch.20107

Strand, M.R., Burke, G.R., 2012. Polydnaviruses as symbionts and gene delivery systems. PLoS pathogens 8, e1002757. doi:10.1371/journal.ppat.1002757

Suzuki, Y., Yanagisawa, M., Ariga, T., Yu, R.K., 2011. Histone acetylation-mediated glycosyltransferase gene regulation in mouse brain during development. Journal of Neurochemistry 116, 874-880. doi:10.1111/j.1471-4159.2010.07042.x

Theilmann, D.A., Stewart, S., 1991. Identification and characterization of the IE-1 gene of Orgyia pseudotsugata multicapsid nuclear polyhedrosis virus. Virology 180, 492-508.

Thiem, S.M., Du, X., Quentin, M.E., Berner, M.M., 1996. Identification of baculovirus gene that promotes Autographa californica nuclear polyhedrosis virus replication in a nonpermissive insect cell line. Journal of virology 70, 2221-9.

Thiem, S.M., Du, X., Quentin, M.E., Berner, M.M., 1996. Identification of baculovirus gene that promotes Autographa californica nuclear polyhedrosis virus replication in a nonpermissive insect cell line. Journal of virology 70, 2221-9.

Thiem, S.M., Miller, L.K., 1990. Differential gene expression mediated by late, very late and hybrid baculovirus promoters. Gene 91, 87-94.

Thiem, S.M., Chejanovsky, N., 2004. The role of baculovirus apoptotic suppressors in AcMNPVmediated translation arrest in Ld652Y cells. Virology 319, 292-305. doi:10.1016/j.virol.2003.11.003 
Thumbi, D.K., Arif, B.M., Krell, P.J., 2007. Susceptibility of Autographa californica multiple nucleopolyhedrovirus to inhibitors of DNA replication. Journal of Virological Methods 146, 209217. doi:10.1016/j.jviromet.2007.07.001

Todd, J.W., Passarelli, A.L., Lu, A., Miller, L.K., 1996. Factors regulating baculovirus late and very late gene expression in transient-expression assays. Journal of virology 70, 2307-17.

Todd, J.W., Passarelli, A.L., Miller, L.K., 1995. Eighteen baculovirus genes, including lef-11, p35, 39K, and p47, support late gene expression. Journal of virology 69, 968-74.

Tomita, S., Kanaya, T., Kobayashi, J., Imanishi, S., 1995. Isolation of p10 gene from Bombyx mori nuclear polyhedrosis virus and study of its promoter activity in recombinant baculovirus vector system. Cytotechnology 17, 65-70.

Trudeau, D., Witherell, R.A., Strand, M.R., 2000. Characterization of two novel Microplitis demolitor polydnavirus mRNAs expressed in Pseudoplusia includens haemocytes. The Journal of general virology 81, 3049-58.

Tweeten, K.A., Bulla, L.A., Consigli, R.A., 1980. Characterization of an extremely basic protein derived from granulosis virus nucleocapsids. Journal of virology 33, 866-76.

Vail, P. V., Sutter, G., Jay, D.L., Gough, D., 1971. Reciprocal infectivity of nuclear polyhedrosis viruses of the cabbage looper and alfalfa looper. Journal of Invertebrate Pathology 17, 383-388. doi:10.1016/0022-2011(71)90013-9

van Loo, N.D., Fortunati, E., Ehlert, E., Rabelink, M., Grosveld, F., Scholte, B.J., 2001. Baculovirus infection of nondividing mammalian cells: mechanisms of entry and nuclear transport of capsids. Journal of virology 75, 961-70. doi:10.1128/JVI.75.2.961-970.2001

van Oers, M.M., Thomas, A.A., Moormann, R.J., Vlak, J.M., 2001. Secretory pathway limits the enhanced expression of classical swine fever virus E2 glycoprotein in insect cells. Journal of biotechnology $86,31-8$.

Vaughn, J.L., Goodwin, R.H., Tompkins, G.J., McCawley, P., 1977. The establishment of two cell lines from the insect Spodoptera frugiperda (Lepidoptera; Noctuidae). In vitro 13, 213-7.

Vinson, S.B., Scott, J.R., 1975. Particles containing DNA associated with the oocyte of an insect parasitoid. Journal of Invertebrate Pathology 25, 375-378. doi:10.1016/0022-2011(75)90097-X

Volkman, L.E., Goldsmith, P.A., 1985. Mechanism of neutralization of budded Autographa californica nuclear polyhedrosis virus by a monoclonal antibody: Inhibition of entry by adsorptive endocytosis Virology 143, 185-195.

Washburn, J.O., Lyons, E.H., Haas-Stapleton, E.J., Volkman, L.E., 1999. Multiple nucleocapsid packaging of Autographa californica nucleopolyhedrovirus accelerates the onset of systemic infection in Trichoplusia ni. Journal of virology 73, 411-6.

Washburn, J.O., Chan, E.Y., Volkman, L.E., Aumiller, J.J., Jarvis, D.L., 2003. Early synthesis of budded virus envelope fusion protein GP64 enhances Autographa californica multicapsid nucleopolyhedrovirus virulence in orally infected Heliothis virescens. Journal of virology 77, 28090 .

Waters, D.J., Barfield, C.S., 1989. Larval Development and Consumption by Anticarsia gemmatalis (Lepidoptera: Noctuidae) Fed Various Legume Species. Environmental Entomology 18, 10061010. doi:10.1093/ee/18.6.1006 
Webb, B.A., Cuit, L., 1997. Promoter analysis of a cysteine-rich Campoletis sonorensis polydnavirus gene. Journal of General Virology 78, 1807-1817. doi:10.1099/0022-1317-78-7-1807

Weber, B., Annaheim, M., Lanzrein, B., 2007. Transcriptional analysis of polydnaviral genes in the course of parasitization reveals segment-specific patterns. Archives of insect biochemistry and physiology 66, 9-22. doi:10.1002/arch.20190

Weyer, U., Possee, R.D., 1989. Analysis of the promoter of the Autographa californica nuclear polyhedrosis virus p10 gene. The Journal of general virology 70 (Pt 1), 203-8.

Wickham, T.J., Davis, T., Granados, R.R., Shuler, M.L., Wood, H.A,. Screening of insect cell lines for the production of recombinant proteins and infectious virus in the baculovirus expression system. Biotechnology progress 8, 391-6. doi:10.1021/bp00017a003

Wilde, M., Klausberger, M., Palmberger, D., Ernst, W., Grabherr, R., 2014. Tnao38, high five and Sf9evaluation of host-virus interactions in three different insect cell lines: Baculovirus production and recombinant protein expression. Biotechnology Letters 36, 743-749. doi:10.1007/s10529-013$1429-6$

Wilson, M.E., Consigli, R.A., 1985. Functions of a protein kinase activity associated with purified capsids of the granulosis virus infecting Plodia interpunctella. Virology 143, 526-35.

Wilson, M.E., Mainprize, T.H., Friesen, P.D., Miller, L.K., 1987. Location, transcription, and sequence of a baculovirus gene encoding a small arginine-rich polypeptide. Journal of virology $61,661-6$.

Wilson, M.E., Price, K.H., 1988. Association of Autographa californica nuclear polyhedrosis virus (AcMNPV) with the nuclear matrix. Virology 167, 233-41.

Wu, T.Y., Liono, L., Chen, S.L., Chen, C.Y., Chao, Y.C., 2000. Expression of highly controllable genes in insect cells using a modified tetracycline-regulated gene expression system. Journal of biotechnology $80,75-83$.

Wyler, T., Lanzrein, B., 2003. Ovary development and polydnavirus morphogenesis in the parasitic wasp Chelonus inanitus. II. Ultrastructural analysis of calyx cell development, virion formation and release. The Journal of general virology $84,1151-63$.

Xu, F., Lynn, D.E., Roode, E.C., Muñoz, D., van Lent, J.W.M., Vlak, J.M., van Oers, M.M., 2010. Establishment of a cell line from Chrysodeixis chalcites permissive for Chrysodeixis chalcites and Trichoplusia ni nucleopolyhedrovirus. Journal of Invertebrate Pathology 105, 56-62. doi:10.1016/j.jip.2010.05.008

Xu, J., Zhang, P., Kusakabe, T., Mon, H., Li, Z., Zhu, L., Iiyama, K., Banno, Y., Morokuma, D., Lee, J.M., 2015. Comparative proteomic analysis of hemolymph proteins from Autographa californica multiple nucleopolyhedrovirus (AcMNPV)-sensitive or -resistant silkworm strains during infections. Comparative Biochemistry and Physiology Part D: Genomics and Proteomics 16, 36-47. doi:10.1016/j.cbd.2015.07.003

Xu, Y.P., Gu, L.Z., Lou, Y.H., Cheng, R.L., Xu, H.J., Wang, W.B., Zhang, C.X., 2012. A baculovirus isolated from wild silkworm encompasses the host ranges of Bombyx mori nucleopolyhedrosis virus and Autographa californica multiple nucleopolyhedrovirus in cultured cells. Journal of General Virology 93, 2480-2489. doi:10.1099/vir.0.043836-0

Yang, S., Miller, L.K., 1999. Activation of baculovirus very late promoters by interaction with very late factor 1. Journal of virology 73, 3404-9.

Yu, D., Achterberg, V., Horstmann, K., K., 2005. World Ichneumonoidea 2004. Taxonomy, Biology, Morphology and Distribution. Taxapad. 
Yu, W., Li, J., Wang, M., Quan, Y., Chen, J., Nie, Z., Lv, Z., Zhang, Y., 2012. The screening and functional study of proteins binding with the BmNPV polyhedrin promoter. Virology journal 9, 90. doi:10.1186/1743-422X-9-90

Zanotto, P.M., Kessing, B.D., Maruniak, J.E., 1993. Phylogenetic interrelationships among baculoviruses: evolutionary rates and host associations. Journal of Invertebrate Pathology 62, 147-164.

Zanotto, P.M., Sampaio, M.J., Johnson, D.W., Rocha, T.L., Maruniak, J.E., 1992. The Anticarsia gemmatalis nuclear polyhedrosis virus polyhedrin gene region: sequence analysis, gene product and structural comparisons. The Journal of general virology 73 ( Pt 5), 1049-56.

Zeiser, A., Elias, C.B., Voyer, R., Jardin, B., Kamen, A.A., 2000. On-line monitoring of physiological parameters of insect cell cultures during the growth and infection process. Biotechnology Progress 16, 803-808. doi:10.1021/bp000092w

Zhang, Y., Tian, B., Xia, H., Guo, T., Wang, J., Wang, S., Wei, Z., Lu, C., 2008. Spread of recombinant Autographa californica nucleopolyhedrovirus in various tissues of silkworm Bombyx mori determined by real-time PCR. Analytical biochemistry 373, 147-53. doi:10.1016/j.ab.2007.09.004 